\title{
Mechanical Properties of \\ Thermally Aged \\ Cast Stainless Steels from \\ Shippingport Reactor Components
}

Manuscript Completed: July 1994

Date Published: April 1995

Prepared by

O. K. Chopra and W. J. Shack

Argonne National Laboratory

9700 South Cass Avenue

Argonne, Illinois 60439

Prepared for

Division of Engineering

Office of Nuclear Regulatory Research

U.S. Nuclear Regulatory Commission

Washington, DC 20555

NRC FIN A2256 
NUREG/CR-6275 


\title{
Mechanical Properties of Thermally Aged Cast Stainless Steels from Shippingport Reactor Components
}

by

\author{
O. K. Chopra and W. J. Shack
}

\begin{abstract}
Thermal embrittlement of static-cast CF-8 stainless steel components from the decommissioned Shippingport reactor has been characterized. Cast stainless steel materials were obtained from four cold-leg check valves, three hot-leg main shutoff valves, and two pump volutes. The actual time-at-temperature for the materials was $\approx 13 \mathrm{y}$ at $\approx 281^{\circ} \mathrm{C}\left(538^{\circ} \mathrm{F}\right)$ for the hot-leg components and $\approx 264^{\circ} \mathrm{C}\left(507^{\circ} \mathrm{F}\right)$ for the cold-leg components. Baseline mechanical properties for as-cast material were determined from tests on either recovery-annealed material, i.e., annealed for $1 \mathrm{~h}$ at $550^{\circ} \mathrm{C}$ and then water quenched, or material from the cooler region of the component. The Shippingport materials show modest decreases in fracture toughness and Charpy-impact properties and a small increase in tensile strength because of relatively low service temperatures and ferrite content of the steel. The procedure and correlations developed at Argonne National Laboratory for estimating mechanical properties of cast stainless steels predict accurate or slightly lower values for Charpy-impact energy, tensile flow stress, fracture toughness $\mathrm{J}-\mathrm{R}$ curve, and $\mathrm{J}_{\mathrm{IC}}$ of the materials. The kinetics of thermal embrittlement and degree of embrittlement at saturation, i.e., the minimum impact energy achieved after long-term aging, were established from materials that were aged further in the laboratory. The results were consistent with the estimates. The correlations successfully predicted the mechanical properties of the Ringhals 2 reactor hot- and crossover-leg elbows (CF-8M steel) after service of $\approx 15 \mathrm{y}$ and the KRB reactor pump cover plate $(\mathrm{CF}-8)$ after $\approx 8 \mathrm{y}$ of service.
\end{abstract}


NUREG/CR-6275 


\section{Contents}

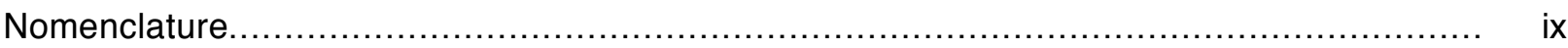

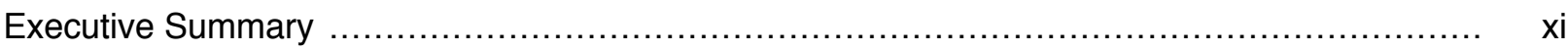

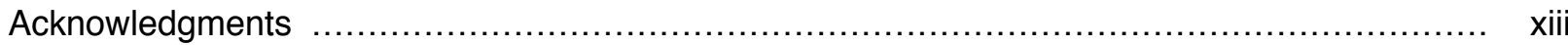

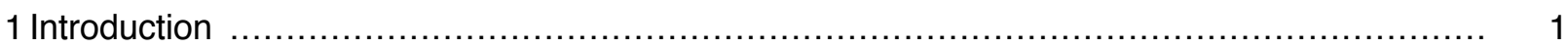

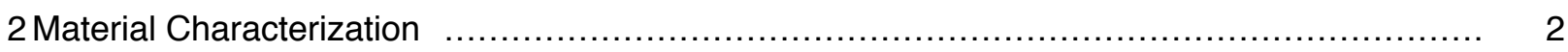

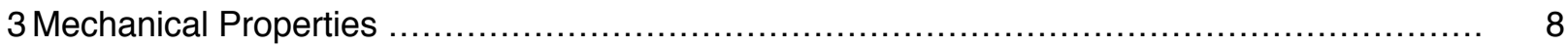

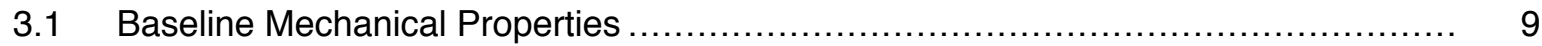

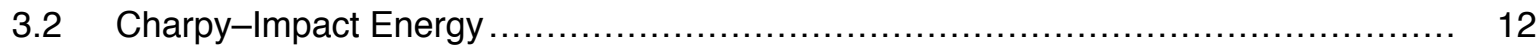

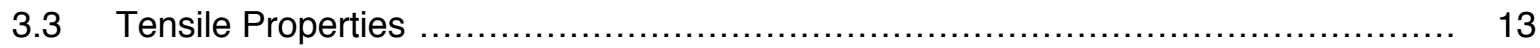

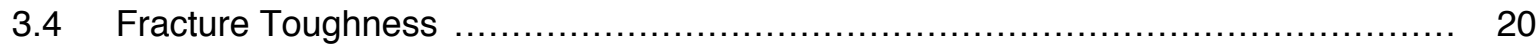

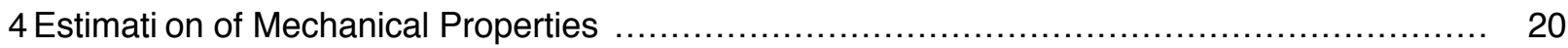

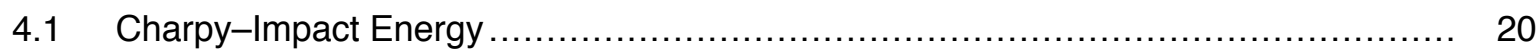

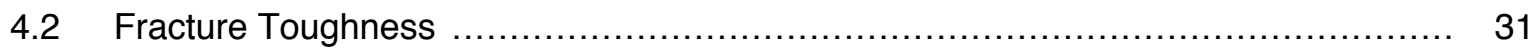

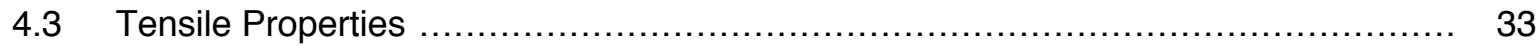

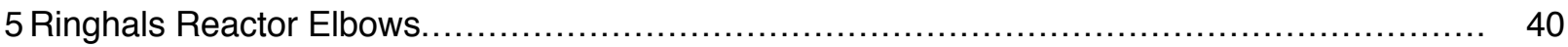

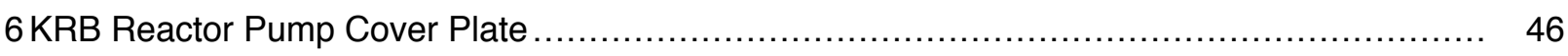

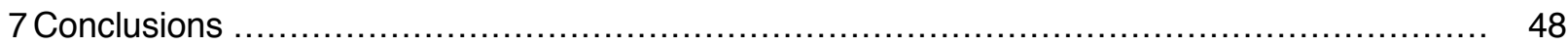

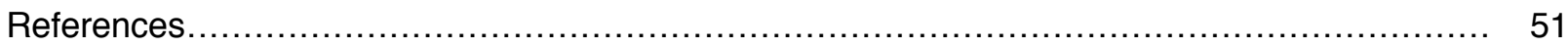

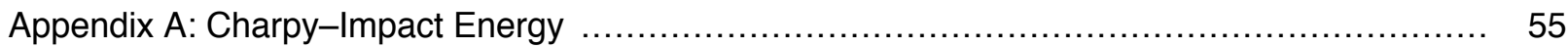

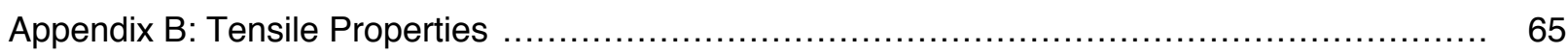

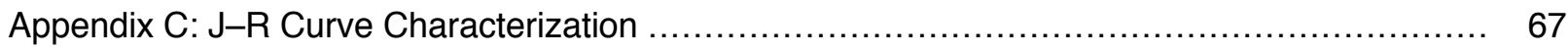




\section{List of Figures}

1. Photographs of check valve, main shutoff valve, and spare pump volute from the Shippingport reactor.

2. Microstructure along axial section of Loop A check valve from the Shippingport

reactor

3. Microstructure along axial section of Loop B main shutoff valve from the Shippingport reactor

4. Microstructure along axial section of the spare volute from the Shippingport reactor

5. Ferrite morphology of cast materials from Loops A, B, and C cold-leg check valves from the Shippingport reactor

6. Ferrite morphology of cast materials from Loops A, B, and C hot-leg main shutoff valves from the Shippingport reactor

7. Ferrite morphology of cast materials from the cold-leg and spare pump volutes from the Shippingport reactor

8. Effect of annealing for $1 \mathrm{~h}$ at $550^{\circ} \mathrm{C}$ and then water quenching on Charpy-transition curves for laboratory-aged Heats 69, 68, and 75, and service-aged KRB pump cover plate.

9. Effect of annealing on Charpy-transition curve of cast material from the hot-leg main shutoff valve

10. Charpy transition curves for Loop A and B cold-leg check valves after 13 y of service at $264^{\circ} \mathrm{C}$

11. Charpy transition curves for Loop A hot-leg main shutoff valve after $13 \mathrm{y}$ of service at $281^{\circ} \mathrm{C}$

12. Charpy transition curves for Loop A pump volute after 13 y of service at $264^{\circ} \mathrm{C}$

13. Charpy transition curves for materials from the spare pump volute and cooler region of the main shutoff valve before and after aging for $10,000 \mathrm{~h}$ at $400^{\circ} \mathrm{C} \ldots \ldots .$.

14. Yield and ultimate stresses estimated from Charpy-impact data and obtained from tensile tests for cold-leg check valve and pump volute, and estimated tensile stresses of annealed materials....

15. Yield and ultimate stresses estimated from Charpy-impact data and obtained from tensile tests for hot-leg main valve, and estimated tensile stresses of annealed materials 
16. Yield and ultimate stresses estimated from Charpy-impact data and obtained from tensile tests for spare pump volute and hot-leg main valve before and after aging for $10,000 \mathrm{~h}$ at $400^{\circ} \mathrm{C}$.

17. Fracture toughness $\mathrm{J}-\mathrm{R}$ curves at room temperature and $290^{\circ} \mathrm{C}$ for annealed, service-aged, and laboratory-aged material from the cold-leg check valve 22

18. Fracture toughness $\mathrm{J}-\mathrm{R}$ curves at room temperature and $290^{\circ} \mathrm{C}$ for unaged, service-aged, and laboratory-aged material from the hot-leg main shutoff valve......

19. Fracture toughness $\mathrm{J}-\mathrm{R}$ curves at room temperature and $290^{\circ} \mathrm{C}$ for annealed, service-aged, and laboratory-aged material from the cold-leg pump volute

20. Fracture toughness $\mathrm{J}-\mathrm{R}$ curves at room temperature and $290^{\circ} \mathrm{C}$ for unaged and laboratory-aged material from the spare pump volute

21. Flow diagram for estimating mechanical properties of cast materials obtained from the Shippingport reactor....

22. Variations of estimated room-temperature Charpy-impact energy with service time for Loop A cold-leg check valve CA4 and pump volute PV ....

23. Variations of estimated room-temperature Charpy-impact energy with time for materials from cooler region of the hot-leg main valve MA9 and spare pump volute VR.

24. Variation of estimated room-temperature Charpy-impact energy with service time for Loop A hot-leg main valve MA1.

25. Estimated and measured fracture toughness J-R curves for the cold-leg check valve in the annealed, $13-y$ service at $264^{\circ} \mathrm{C}$, and fully embrittled or saturation condition

26. Estimated and measured fracture toughness $\mathrm{J}-\mathrm{R}$ curves for the hot-leg main shutoff valve in essentially unaged, $13-y$ service at $281^{\circ} \mathrm{C}$, and fully embrittled or saturation condition.

27. Estimated and measured fracture toughness J-R curves for the cold-leg pump volute in the annealed, $13-\mathrm{y}$ service at $264^{\circ} \mathrm{C}$, and fully embrittled or saturation condition

28. Estimated and measured fracture toughness $\mathrm{J}-\mathrm{R}$ curves for the spare pump volute in the unaged and fully embrittled or saturation condition.

29. Estimated and measured tensile stress-vs.-strain curves at room temperature and $290^{\circ} \mathrm{C}$ for the cold-leg check valve after service for $\approx 13$ y at $264^{\circ} \mathrm{C}$

30. Estimated and measured tensile stress-vs.-strain curves at room temperature and $290^{\circ} \mathrm{C}$ for the hot-leg main shutoff valve after service for $\approx 13$ y at $281^{\circ} \mathrm{C}$ 
31. Estimated and measured tensile stress-vs.-strain curves at room temperature and $290^{\circ} \mathrm{C}$ for the cold-leg pump volute after service for $\approx 13$ y at $264^{\circ} \mathrm{C}$

32. Estimated and measured tensile stress-vs.-strain curves at room temperature and $290^{\circ} \mathrm{C}$ for material from cooler regions of the hot-leg main shutoff valve in the unaged and fully embrittled or aged condition.

33. Estimated and measured tensile stress-vs.-strain curves at room temperature and $290^{\circ} \mathrm{C}$ for the spare pump volute in the unaged and fully embrittled or aged

condition

34. Estimated and experimentally observed room-temperature Charpy-impact energy for the Ringhals hot- and crossover-leg elbows

35. Estimated fracture toughness J-R curves for the Ringhals hot- and crossover-leg elbows in the unaged condition, after service, and at saturation.

36. Variation of estimated room-temperature Charpy-impact energy with service time for the KRB pump cover plate.

37. Estimated and measured tensile stress-vs.-strain curves at room temperature and $290^{\circ} \mathrm{C}$ for the KRB pump cover plate in the annealed condition and after 8 y of service at $284^{\circ} \mathrm{C}$

38. Estimated and measured fracture toughness J-R curve for the KRB pump cover plate in the annealed or unaged condition, after service, and at saturation.....

\section{List of Tables}

1. Chemical composition, ferrite morphology, and hardness of cast stainless steel components from the Shippingport, KRB, and Ringhals reactors

2. Values of constants in Eq. 1 for Charpy transition curve of CF-8 cast SSs from the Shippingport reactor and KRB pump cover plate.

3. Measured and estimated Charpy-impact properties of cast stainless steel materials from the Shippingport, KRB, and Ringhals reactors .....

4. Measured and estimated tensile yield and flow stresses and $\mathrm{J}_{\mathrm{I}} \mathrm{C}$ values for serviceand laboratory-aged cast stainless steels 


\section{Nomenclature}

b Uncracked ligament of Charpy-impact specimen ( $\mathrm{mm})$.

B Thickness of Charpy-impact speciemn (mm).

C Coefficient of power-law $J-R$ curve expressed as $J_{d}=C(\Delta a)^{n}$.

$\mathrm{Cr}_{\text {eq }}$ Chromium equivalent for a material (wt.\%).

CV Room-temperature "normalized" Charpy-impact energy, i.e., Charpy-impact energy per unit fracture area, at any given service and aging time $\left(\mathrm{J} / \mathrm{cm}^{2}\right)$. Fracture area for a standard Charpy V-notch specimen (ASTM Specification E 23) is $0.8 \mathrm{~cm}^{2}$. Divide the value of impact energy in $\mathrm{J}$ by 0.8 to obtain "normalized" impact energy.

CVint Initial room-temperature "normalized" Charpy-impact energy of a material, i.e., unaged material $\left(\mathrm{J} / \mathrm{cm}^{2}\right)$.

CVsat Room-temperature "normalized" Charpy-impact energy of a material at saturation, i.e., minimum impact energy that would be achieved for the material after long-term service $\left(\mathrm{J} / \mathrm{cm}^{2}\right)$.

CMTR Certified material test record.

E Modulus of elasiticity (MPa).

$J_{d} \quad$ Deformation J per ASTM Specification E 813-85 or E 1152-87 $\left(\mathrm{kJ} / \mathrm{m}^{2}\right)$.

$\mathrm{n} \quad$ Exponent of power-law J-R curve.

$\mathrm{n}_{1} \quad$ Ramberg-Osgood parameter.

$\mathrm{Ni}_{\text {eq }} \quad$ Nickel equivalent for a material (wt.\%).

P Aging parameter, i.e., log of time of aging at $400^{\circ} \mathrm{C}$.

$\mathrm{P}_{\mathrm{m}} \quad$ Maximum load for instrumented Charpy-impact test $(\mathrm{N})$.

$\mathrm{Py}_{\mathrm{y}} \quad$ Yield load for instrumented Charpy-impact test $(\mathrm{N})$.

Q Activation energy for process of thermal embrittlement $(\mathrm{kJ} / \mathrm{mole})$.

$R_{f} \quad$ Ratio of tensile flow stress of aged and unaged cast stainless steel.

$\mathrm{R}_{\mathrm{y}} \quad$ Ratio of tensile yield stress of aged and unaged cast stainless steel.

$\mathrm{t} \quad$ Service or aging time (h).

$\mathrm{T}_{\mathrm{S}} \quad$ Service or aging temperature $\left({ }^{\circ} \mathrm{C}\right)$.

W Width of Charpy-impact specimen $(\mathrm{mm})$.

$\alpha \quad$ Shape factor of curve for change in room-temperature Charpy-impact energy with time and temperature of aging.

$\alpha_{1} \quad$ Ramberg-Osgood parameter.

$\beta \quad$ Half the maximum change in room-temperature Charpy-impact energy.

$\delta_{\mathrm{c}} \quad$ Ferrite content calculated from chemical composition of a material (\%).

$\Delta$ a Crack extension ( $\mathrm{mm})$. 
$\varepsilon \quad$ Engineering strain.

$\varepsilon_{0} \quad$ Reference strain in Ramberg-Osgood equation.

$\Phi \quad$ Material parameter.

$\theta \quad$ Aging behavior at $400^{\circ} \mathrm{C}$, i.e., log of time to achieve $\beta$ reduction in impact energy at $400^{\circ} \mathrm{C}$.

$\sigma_{f} \quad$ Engineering flow stress expressed as average value of yield and ultimate stress, i.e., $\left(\sigma_{y}+\sigma_{u}\right) / 2(\mathrm{MPa})$.

$\sigma_{\mathrm{o}} \quad$ Reference stress in Ramberg-Osgood equation (MPa).

$\sigma_{\mathrm{u}} \quad$ Engineering ultimate stress (MPa).

$\sigma_{\mathrm{y}} \quad$ Engineering yield stress (MPa).

In this report, all values of impact energy are considered to be for a standard Charpy-V-notch specimen per ASTM Specification E 23, i.e., $10 \times 10-\mathrm{mm}$ cross section and 2-mm V notch. Impact energies obtained on subsize specimens should be normalized with respect to the actual cross-sectional area and appropriate correction factors should be applied to account for size effects. Similarly, impact energy from other standards, e.g., U-notch specimen, should be converted to a Charpy-V-notch value by appropriate correlations.

SI units of measure have been used in this report. Conversion factors for measurements in British units are as follows:

$\begin{array}{lll}\text { To convert from } & \text { to } & \text { multiply by } \\ \text { in. } & \mathrm{mm} & 25.4 \\ \mathrm{~J}^{\star} & \mathrm{ft} \cdot \mathrm{lb} & 0.7376 \\ \mathrm{~kJ} / \mathrm{m}^{2} & \text { in.-lb/in. } 2 & 5.71015 \\ \mathrm{~kJ} / \mathrm{mole} & \mathrm{kcal} / \mathrm{mole} & 0.239\end{array}$

\footnotetext{
*When impact energy is expressed in $\mathrm{J} / \mathrm{cm}^{2}$, first multiply by 0.8 to obtain impact energy of a standard Charpy $\mathrm{V}$-notch specimen in J.
} 


\section{Executive Summary}

Cast duplex stainless steels are used extensively in the nuclear industry for valve bodies, pump casings, and primary coolant piping. The ferrite phase in the duplex structure of austenitic-ferritic stainless steels increases the tensile strength and improves the soundness of casting, weldability, and resistance to stress corrosion cracking of these steels. However, these steels are susceptible to thermal embrittlement after extended service at reactor operating temperatures. Recent data have shown that thermal embrittlement of cast stainless steel components can occur during the reactor design life of $40 \mathrm{y}$. Thermal aging of cast stainless steels at these temperatures causes an increase in hardness and tensile strength; a decrease in ductility, impact strength, and fracture toughness of the material; and a shift of the Charpy transition curve to higher temperatures. In general, the low-C CF-3 steels are the most resistant to thermal embrittlement, and the Mo-bearing, high-C CF-8M steels are the least resistant.

Therefore, mechanical-property degradation due to thermal embrittlement must be assessed so that the performance of cast stainless steel components during prolonged exposure to service temperatures can be evaluated, because rupture of the primary pressure boundary could lead to a loss-of-coolant accident and possible exposure of the public to radiation. A procedure and correlations have been developed at Argonne National Laboratory for estimating fracture toughness, tensile, and Charpy-impact properties of cast stainless steel components from known material information. Mechanical properties of a specific cast stainless steel are estimated from the extent and kinetics of thermal embrittlement. Because the embrittlement mechanisms and kinetics are complex, mechanical testing of actual component materials that have completed long in-reactor service is necessary to ensure that the mechanisms observed in accelerated aging experiments are the same as those occurring in reactors. Cast stainless steel materials from the decommissioned Shippingport reactor offered a unique opportunity to validate the correlations and benchmark the laboratory studies. The mechanical-property degradation of cast stainless steel components from the Shippingport reactor is characterized in this report. The results are compared with estimates from accelerated laboratory aging studies.

Cast stainless steel materials were obtained from four cold-leg check valves, three hot-leg main shutoff valves, and two pump volutes. The actual time-at-temperature for the materials was $\approx 13$ y at $\approx 281^{\circ} \mathrm{C}\left(538^{\circ} \mathrm{F}\right)$ for the hot-leg components and $\approx 264^{\circ} \mathrm{C}\left(507^{\circ} \mathrm{F}\right)$ for the cold-leg components. The various cast materials were analyzed to determine their chemical composition, hardness, grain structure, and ferrite content and distribution. All materials from the Shippingport reactor are CF-8 cast stainless steel, with ferrite contents in the range of $2-16 \%$. In general, hardness increases with increases in the ferrite content of the steel. Some differences in hardness and ferrite content were observed for material from different locations in the casting. Such differences appear to be related to compositional variations. All valve materials have a radially oriented columnar grain structure. The pump volutes exhibit a mixed grain structure of columnar and equiaxed grains. The materials contain a lacy ferrite with a mean ferrite spacing in the range of 150-300 $\mu \mathrm{m}$. The check-valve materials show a significant amount of carbides at the ferrite/austenite phase boundaries.

Charpy-impact, tensile, and fracture toughness properties of several cast stainless steel materials from the Shippingport reactor have been characterized. Baseline mechanical properties of the unaged material were determined from tests on either recovery-annealed material, 
i.e., material that had been annealed for $1 \mathrm{~h}$ at $550^{\circ} \mathrm{C}$ and then water quenched, or on material from a cooler region of the component. The Shippingport materials exhibited modest degradation of mechanical properties, as would be expected at the relatively low operating temperatures. The room-temperature Charpy-impact energies of the materials are relatively high and the mid-shelf Charpy transition temperatures are very low. Check valve materials were weaker than main valve materials because of the presence of phase-boundary carbides.

Some materials were aged further in the laboratory to determine the kinetics of embrittlement and the saturation or minimum fracture properties of a specific material. The results indicate that the Shippingport cast stainless steels are not very susceptible to thermal embrittlement at reactor operating temperatures. Even at saturation or fully embrittled condition, the room-temperature impact energy of the materials is $>60 \mathrm{~J} / \mathrm{cm}^{2}(>35 \mathrm{ft} \cdot \mathrm{lb})$ and the room-temperature $J_{d}$ value is $>600 \mathrm{~kJ} / \mathrm{m}^{2}\left(>3400 \mathrm{in} .-\mathrm{lb} / \mathrm{in} .{ }^{2}\right)$ at $5-\mathrm{mm}$ crack extension.

The values obtained for the reactor-aged materials show good agreement with estimations based on accelerated laboratory aging studies. The procedure and correlations for estimating thermal aging degradation of cast stainless steels predict accurate or slightly conservative values for Charpy-impact energy, tensile flow stress, fracture toughness $\mathrm{J}-\mathrm{R}$ curve, and $\mathrm{J}_{\mathrm{IC}}$. The correlations also successfully predict the mechanical properties of the Ringhals reactor hot- and crossover-leg elbows after $\approx 15 \mathrm{y}$ of service and the KRB reactor pump cover plate after $\approx 8 \mathrm{y}$ of service. 


\section{Acknowledgments}

This work was supported by the Office of the Nuclear Regulatory Research in the U.S. Nuclear Regulatory Commission (NRC), under FIN A2256, Program Manager: Edward O. Woolridge. The authors are grateful to A. Sather, L. Y. Bush, T. M. Galvin, G. M. Dragel, P. T. Toben, and W. F. Burke for their contribution to the experimental effort. The methodology and correlations for estimating mechanical properties of aged cast stainless steels have been developed as part of a program entitled "Long-Term Embrittlement of Cast Stainless Steels in LWR Systems," sponsored by the U.S. NRC, under FIN A2243, Program Manager: Joe Muscara. 
NUREG/CR-6275 


\section{Introduction}

Cast duplex stainless steels (SSs) are used extensively in the nuclear industry for valve bodies, pump casings, and primary coolant piping. The ferrite phase in the duplex structure of austenitic-ferritic SSs increases the tensile strength and improves the soundness of casting, weldability, and resistance to stress corrosion cracking of these steels. However, these steels are susceptible to thermal embrittlement after extended service at reactor operating temperatures, i.e., typically $282^{\circ} \mathrm{C}\left(540^{\circ} \mathrm{F}\right)$ for boiling water reactors, $288-327^{\circ} \mathrm{C}\left(550-621^{\circ} \mathrm{F}\right)$ for pressurized water reactor (PWR) primary coolant piping, and $343^{\circ} \mathrm{C}\left(650^{\circ} \mathrm{F}\right)$ for PWR pressurizers. Thermal aging of cast SSs at these temperatures causes an increase in hardness and tensile strength; decrease in ductility, impact strength, and fracture toughness of the material; and a shift of the Charpy transition curve to higher temperatures. Therefore, to evaluate the performance of cast SS components during prolonged exposure to service temperatures, we must assess the mechanical-property degradation that is due to thermal embrittlement, because rupture of the primary pressure boundary could lead to a loss-of-coolant accident and possible exposure of the public to radiation.

Investigations at Argonne National Laboratory $(A N L)^{1-8}$ and elsewhere ${ }^{9-16}$ have shown that thermal embrittlement of cast SSs (i.e., ASTM Specification A-351 grades ${ }^{*}$ CF-3, CF-3A, CF-8, CF-8A, and CF-8M) can occur during the reactor design life of $40 \mathrm{y}$. Cast SS components with even modest ferrite content, e.g., 10-15\% ferrite, may show significant thermal embrittlement. For example, the hot-leg elbow from the Ringhals 2 reactor showed poor fracture properties, e.g., room-temperature (RT) Charpy-impact energy of $36 \mathrm{~J}$ $(\approx 26 \mathrm{ft} \cdot \mathrm{lb})$ and fracture toughness $J_{I C}$ values of $150-330 \mathrm{~kJ} / \mathrm{m}^{2} \quad\left(856-1884 \mathrm{in} \cdot \mathrm{lb} / \mathrm{in}^{2}\right) .{ }^{17} \mathrm{In}$ general, various grades and heats of cast SS exhibit varying degrees of thermal embrittlement. The low-C CF-3 steels are the most resistant to thermal embrittlement, and the Mo-bearing, high-C CF-8M steels are the least resistant.

Thermal embrittlement of cast SSs results in brittle fracture associated with either cleavage of the ferrite or separation of the ferrite/austenite phase boundary. Aging of cast SSs at temperatures $<500^{\circ} \mathrm{C}\left(<932^{\circ} \mathrm{F}\right)$ leads to precipitation of additional phases in the ferrite, e.g., formation of a $\mathrm{Cr}$-rich $\alpha^{\prime}$ phase by spinodal decomposition; nucleation and growth of $\alpha^{\prime}$; precipitation of a $\mathrm{Ni}-$ and $\mathrm{Si}-$ rich $\mathrm{G}$ phase, $\mathrm{M}_{23} \mathrm{C}_{6}$, and $\gamma_{2}$ (austenite); and additional precipitation and/or growth of existing carbides at the ferrite/austenite phase boundaries. Thermal embrittlement is caused primarily by formation of the $\mathrm{Cr}$-rich $\alpha^{\prime}$ phase and, to some extent, by precipitation and growth of carbides at the phase boundaries. Formation of the $\alpha$ ' phase increases strain hardening and local tensile stress. Consequently, the critical stress level for brittle fracture is attained at higher temperatures. Predominantly brittle failure occurs when either the ferrite phase is continuous (e.g., in cast material with a large ferrite content) or the ferrite/austenite phase boundary provides an easy path for crack propagation (e.g., in high-C grades of cast steel with large phase-boundary carbides). The amount, size, and distribution of the ferrite phase in the duplex structure, and the presence of phase-boundary carbides are important parameters in controlling the degree or extent of thermal embrittlement.

\footnotetext{
*In this report, grades $\mathrm{CF}-3 \mathrm{~A}$ and $\mathrm{CF}-8 \mathrm{~A}$ are considered equivalent to $\mathrm{CF}-3$ and $\mathrm{CF}-8$, respectively. The A designation represents high tensile strength. The chemical composition of CF-3A and CF-8A are further restricted within the composition limits of $\mathrm{CF}-3$ and $\mathrm{CF}-8$, respectively, to obtain a ferrite/austenite ratio that results in higher ultimate and yield strengths.
} 
A procedure and correlations have been developed for estimating fracture toughness, tensile, and Charpy-impact properties of cast SS components from known material information. ${ }^{5-8}$ Mechanical properties of a specific cast SS are estimated from the extent and kinetics of thermal embrittlement. The extent of thermal embrittlement is characterized by the RT Charpy-impact energy. A correlation for the extent of thermal embrittlement at "saturation," i.e., the minimum impact energy that would be achieved for the material after long-term aging, is given in terms of the chemical composition. The extent of thermal embrittlement as a function of time and temperature of reactor service is estimated from the extent of embrittlement at saturation and from the correlations that describe the kinetics of embrittlement, which are also given in terms of chemical composition. The fracture toughness $\mathrm{J}-\mathrm{R}$ curve for the material is then obtained from the correlation between the fracture toughness parameters and the RT Charpy-impact energy that is used to characterize the extent of thermal embrittlement. Tensile yield and flow stresses, and Ramberg/Osgood parameters for tensile strain hardening are estimated from the flow stress of the unaged material and the kinetics of embrittlement. Fracture toughness $J_{I C}$ and tearing modulus can then be determined from the estimated $J-R$ curve and tensile flow stress.

Because the embrittlement mechanisms and kinetics are complex, mechanical testing of actual component materials that have completed long in-reactor service is necessary to ensure that the mechanisms observed in accelerated aging experiments are the same as those that occur in reactors. Cast SS materials from the decommissioned Shippingport reactor offered a unique opportunity to validate the correlations and benchmark the laboratory studies. Degradation of the mechanical properties of cast SS components from the Shippingport reactor has been characterized in this report. The results are compared with estimates from accelerated laboratory aging studies.

Degradation of the mechanical properties of cast SS materials from the hot-leg and crossover-leg elbows of the Ringhals 2 reactor in Sweden and from the recirculating-pump cover assembly of the KRB reactor in Gundremmingen, Germany, is also assessed and compared with experimental data. The elbows, constructed of CF-8M steel, were in service for $\approx 13 \mathrm{y}$ at $325^{\circ} \mathrm{C}\left(617^{\circ} \mathrm{F}\right)$ for the hot leg and at $291^{\circ} \mathrm{C}\left(556^{\circ} \mathrm{F}\right)$ for the crossover leg, and at hot standby for $\approx 2 \mathrm{y}$ at $303^{\circ} \mathrm{C}\left(577^{\circ} \mathrm{F}\right)$ for the hot leg and at $274^{\circ} \mathrm{C}\left(525^{\circ} \mathrm{F}\right)$ for the crossover leg. The recirculating-pump cover assembly of the KRB reactor was constructed of CF-8 steel and was in service for $\approx 8$ y at $284^{\circ} \mathrm{C}\left(543^{\circ} \mathrm{F}\right)$.

\section{Material Characterization}

Cast SS materials were obtained from four cold-leg check valves, three hot-leg main shutoff valves, and two pump volutes. One of the volutes was a "spare" that had seen service only during the first core loading; the other was in service for the entire life of the plant. The actual time-at-temperature for the materials was $\approx 13$ y at $\approx 281^{\circ} \mathrm{C}\left(538^{\circ} \mathrm{F}\right)$ for the hot-leg components and $\approx 264^{\circ} \mathrm{C}\left(507^{\circ} \mathrm{F}\right)$ for the cold-leg components. The components were in a hot-standby condition of $\approx 204^{\circ} \mathrm{C}\left(399^{\circ} \mathrm{F}\right)$ for an additional $\approx 2 \mathrm{y}$. Photographs of the check valve, main shutoff valve, and spare pump volute are shown in Fig. 1.

The various cast materials were characterized to determine their chemical composition, hardness, grain structure, and ferrite content and distribution. Samples were obtained from different locations of the casting and from different regions across the thickness of the wall. 


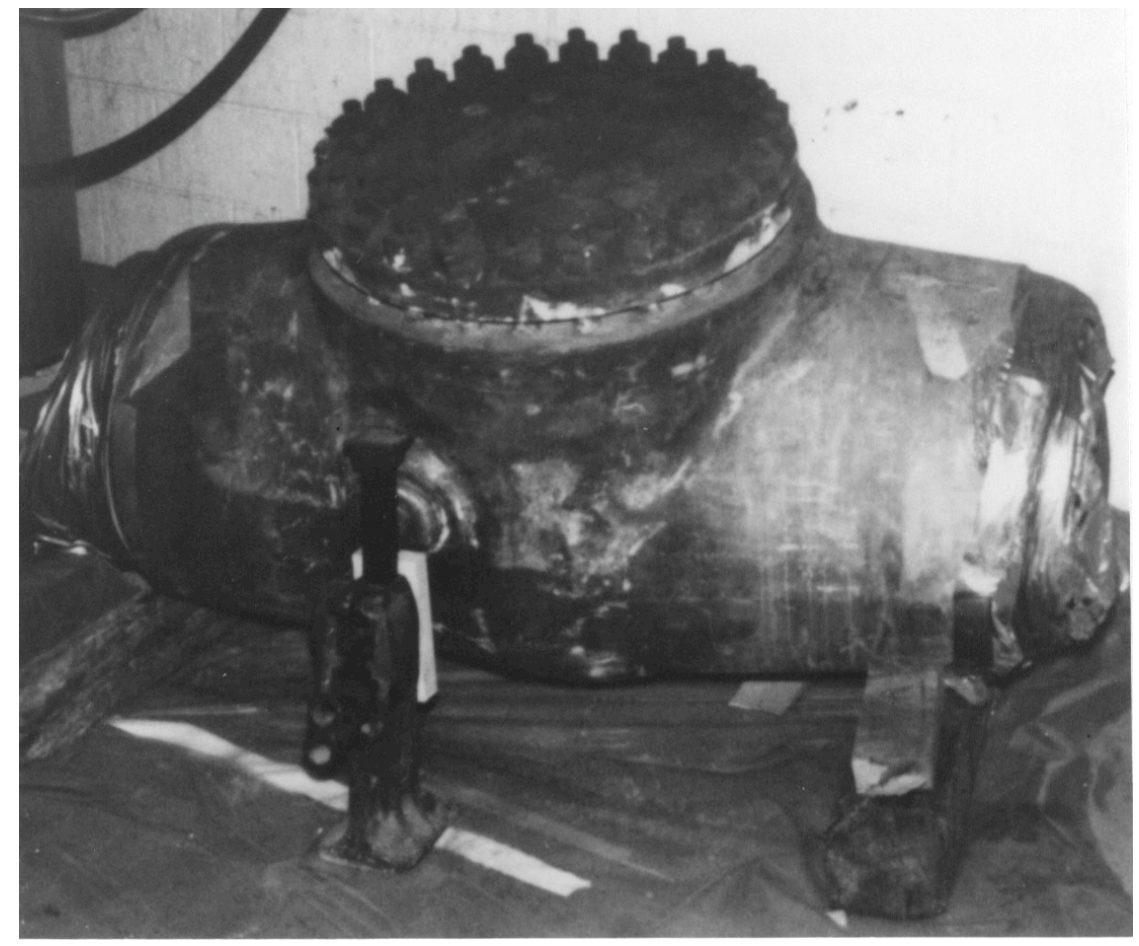

(a)

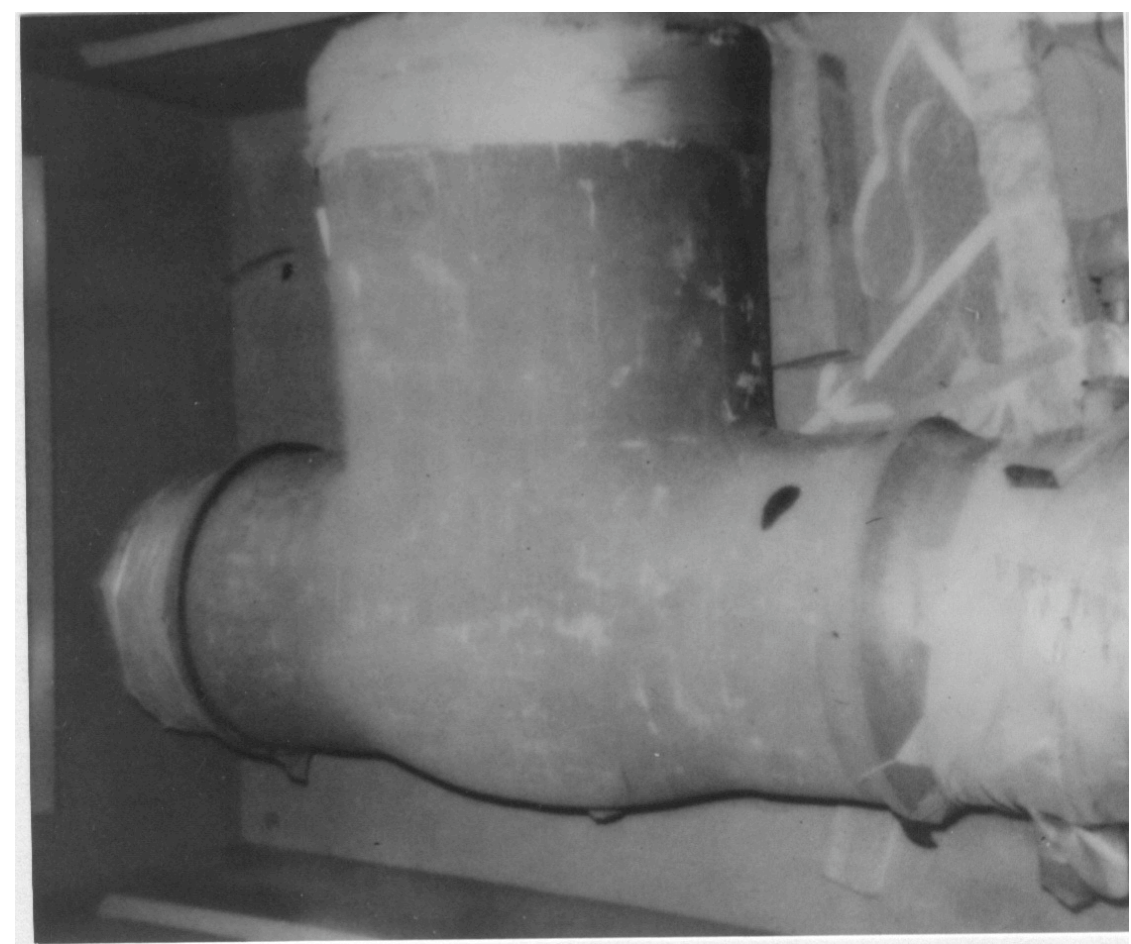

(b)

Figure 1. Photographs of (a) check valve, (b) main shutoff valve, and (c) spare pump volute from the Shippingport reactor 


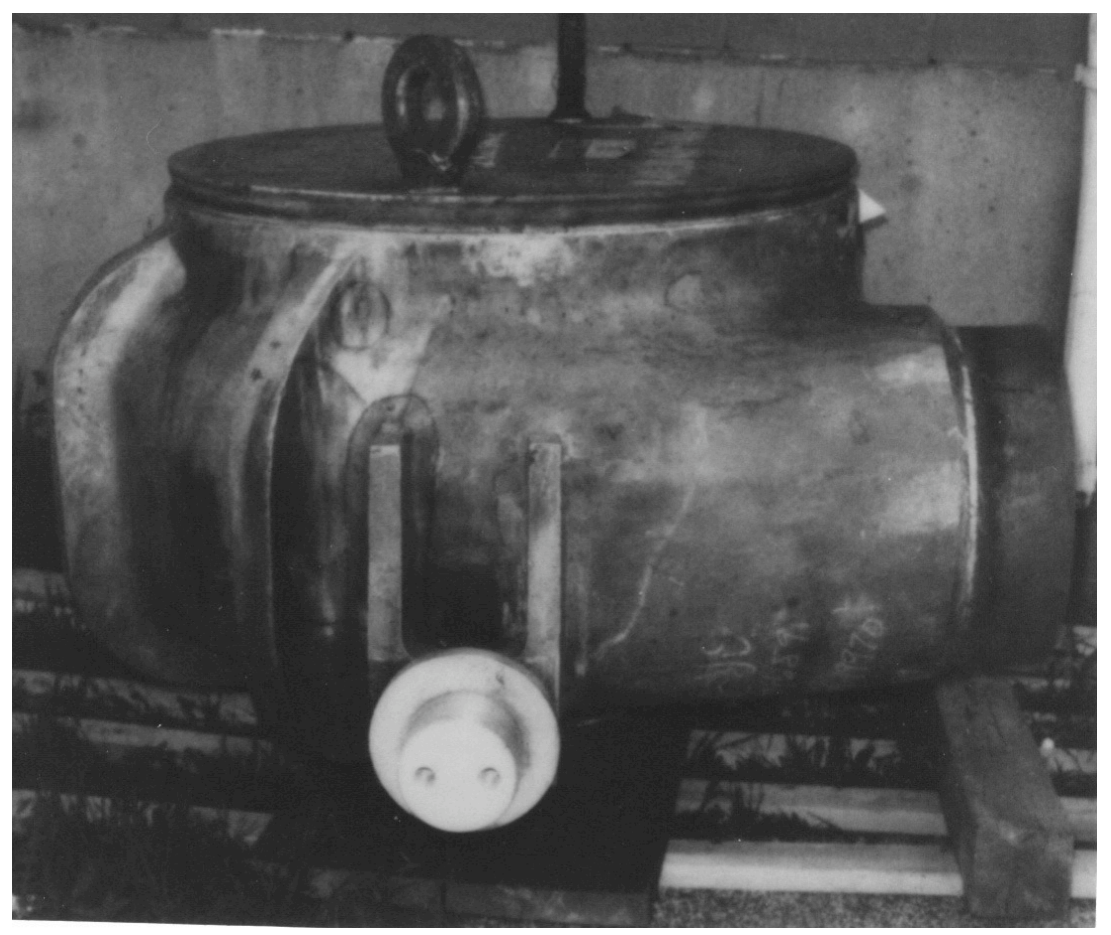

(c)

Figure 1. (Contd.)

The chemical composition, hardness, and amount and distribution of ferrite for the cast materials are given in Table 1. The chemical composition and ferrite content of the hot-leg and crossover-leg elbows from the Ringals 2 reactor and the pump cover plate from the KRB reactor are also included in Table 1. All materials from the Shippingport reactor are CF-8 cast SS with ferrite content in the range of $2-16 \%$. In general, hardness increases with increases in ferrite content of the steel. Some differences in hardness and ferrite content were observed for material from different locations in the casting. Such differences appear to be related to compositional variations.

All valve materials exhibit a radially oriented columnar grain structure. Typical examples of the grain structure for the check valves and main shutoff valves are shown in Figs. 2 and 3, respectively. The inner surface of all of the valves contained repair welds; an example is shown in Fig. 3. The pump volutes display a mixed grain structure of columnar and equiaxed grains, Fig. 4. The ferrite morphologies of the check valves, main shutoff valves, and the pump volutes are shown in Figs. 5, 6, and 7, respectively. The materials contain a lacy ferrite with a mean ferrite spacing in the range of $150-300 \mu \mathrm{m}$. The check valve materials show a significant amount of carbides at the ferrite/austenite phase boundaries. Furthermore, most of the phase boundaries have migrated. The original phase boundaries are decorated with carbides, which most likely formed during production heat treatment of the casting.

Microstructural examination indicates that the mechanism of low-temperature embrittlement of the cast materials is the same as that of laboratory-aged materials. ${ }^{18,19}$ All materials showed spinodal decomposition of ferrite to form a Cr-rich $\alpha^{\prime}$ phase. In addition, the materials from the check valve contained a $\mathrm{Ni}$ - and $\mathrm{Si}$-rich $\mathrm{G}$ phase in the ferrite, and $\mathrm{M}_{23} \mathrm{C}_{6}$ carbides at the austenite/ferrite phase boundary. An unexpected microstructural feature, i.e., $\sigma-p h a s e$ 
Table 1. Chemical composition, ferrite morphology, and hardness of cast stainless steel components from the Shippingport, KRB, and Ringhals reactors

\begin{tabular}{|c|c|c|c|c|c|c|c|c|c|c|c|c|c|}
\hline \multirow{2}{*}{$\begin{array}{c}\text { Mater. } \\
\text { ID }^{\mathrm{a}}\end{array}$} & \multicolumn{9}{|c|}{ Composition, wt.\% } & \multicolumn{2}{|c|}{ Ferrite,\% } & \multirow{2}{*}{$\begin{array}{c}\text { Ferrite } \\
\text { Spacing, } \\
\mu \mathrm{m}\end{array}$} & \multirow{2}{*}{$\begin{array}{c}\text { tard-nes } \\
\text { s, } \\
\mathrm{R}_{\mathrm{B}} \\
\end{array}$} \\
\hline & $\mathrm{C}$ & $\mathrm{Si}$ & $\mathrm{Mn}$ & $\mathrm{P}$ & $S$ & $\mathrm{Ni}$ & $\mathrm{Cr}$ & Mo & $\mathrm{Cu}$ & Calc. & Meas. & & \\
\hline \multicolumn{14}{|c|}{ Cold-Leg Check Valve ${ }^{b}$} \\
\hline CA4 & 0.056 & 0.0411 .45 & 1.10 & 0.018 & 0.009 & 8.84 & 20.26 & 0.01 & 0.07 & 10.8 & 10.9 & 157 & 79.8 \\
\hline CA7 & 0.058 & 0.0411 .43 & 1.09 & 0.018 & 0.009 & 8.72 & 20.22 & 0.01 & 0.07 & 10.9 & 10.0 & 148 & 78.6 \\
\hline CB7 & 0.052 & 0.0531 .36 & 1.07 & 0.018 & 0.011 & 8.85 & 19.12 & 0.02 & 0.06 & 5.9 & 3.2 & 296 & 75.0 \\
\hline \multicolumn{14}{|c|}{$\underline{\text { Hot-Leg Main Shutoff Valve }}$} \\
\hline MA1 & 0.052 & 0.0490 .22 & 0.72 & 0.039 & 0.013 & 10.50 & 20.74 & 0.24 & 0.13 & 5.2 & 9.5 & 217 & 76.9 \\
\hline MA9 & 0.052 & 0.0510 .24 & 0.72 & 0.041 & 0.011 & 10.54 & 20.78 & 0.24 & 0.13 & 5.1 & 10.0 & 245 & 77.6 \\
\hline MB2 & 0.042 & 0.0730 .51 & 0.72 & 0.043 & 0.017 & 10.77 & 19.74 & 0.19 & 0.12 & 2.6 & 1.9 & - & 74.2 \\
\hline \multicolumn{14}{|c|}{ Pump Volute $^{\mathrm{C}}$} \\
\hline VR & 0.046 & 0.0491 .14 & 0.50 & 0.027 & 0.017 & 9.56 & 20.79 & 0.04 & 0.07 & 9.8 & 16.2 & 181 & 82.9 \\
\hline PV & 0.108 & 0.0270 .89 & 1.11 & 0.032 & 0.008 & 9.30 & 19.83 & 0.38 & 0.25 & 4.7 & 13.0 & - & - \\
\hline \multicolumn{14}{|c|}{$\underline{\text { KRB Pump Cover Plate }}$} \\
\hline KRB & 0.062 & 0.0381 .17 & 0.31 & - & - & 8.03 & 21.99 & 0.17 & - & 27.7 & 34.0 & - & - \\
\hline \multicolumn{14}{|c|}{ Ringhals Reactor Elbows ${ }^{\mathrm{e}}$} \\
\hline $\mathrm{H}$ & 0.037 & 0.0441 .03 & 0.77 & 0.022 & 0.008 & 10.60 & 20.00 & 2.09 & 0.17 & 13.0 & 20.1 & - & - \\
\hline C & 0.039 & 0.0371 .11 & 0.82 & 0.020 & 0.012 & 10.50 & 19.60 & 2.08 & 0.08 & 12.3 & 19.8 & - & - \\
\hline
\end{tabular}

a For the valves, the second letter indicates the loop where the valve was located and the number designates the segment of the component from which the material was removed. Segments 1, 2, and 7 are from the top half of the valve body and segment 4 is from the bottom half. Segment 9 of the main shutoff valves is from a cooler region, i.e., casing for valve stem and bonnet.

b In service for $\approx 13$ y at $264^{\circ} \mathrm{C}$ for cold leg and at $281^{\circ} \mathrm{C}$ for hot leg.

c Spare pump volute VR in service only during initial core loading and $P V$ in service for $\approx 13$ y at $264^{\circ} \mathrm{C}$.

d In service for $\approx 8$ y at $284^{\circ} \mathrm{C}$.

e In service for $\approx 13$ y at $325^{\circ} \mathrm{C}$ for hot leg and at $291^{\circ} \mathrm{C}$ for crossover leg, and at hot standby for $\approx 2$ y at $303^{\circ} \mathrm{C}$ for hot leg and $274^{\circ} \mathrm{C}$ for crossover leg.

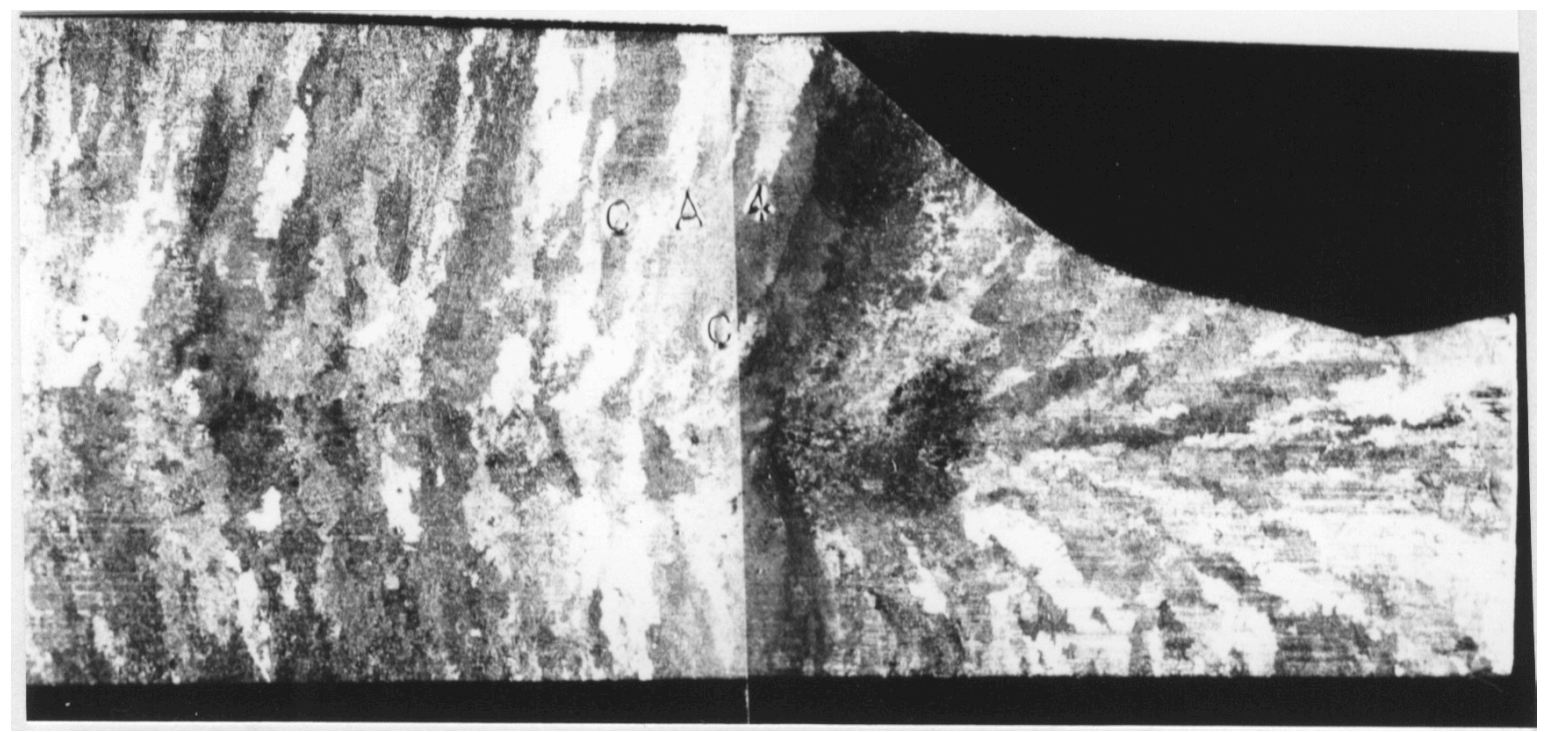

Figure 2. Microstructure along axial section of Loop A check valve from the Shippingport reactor 


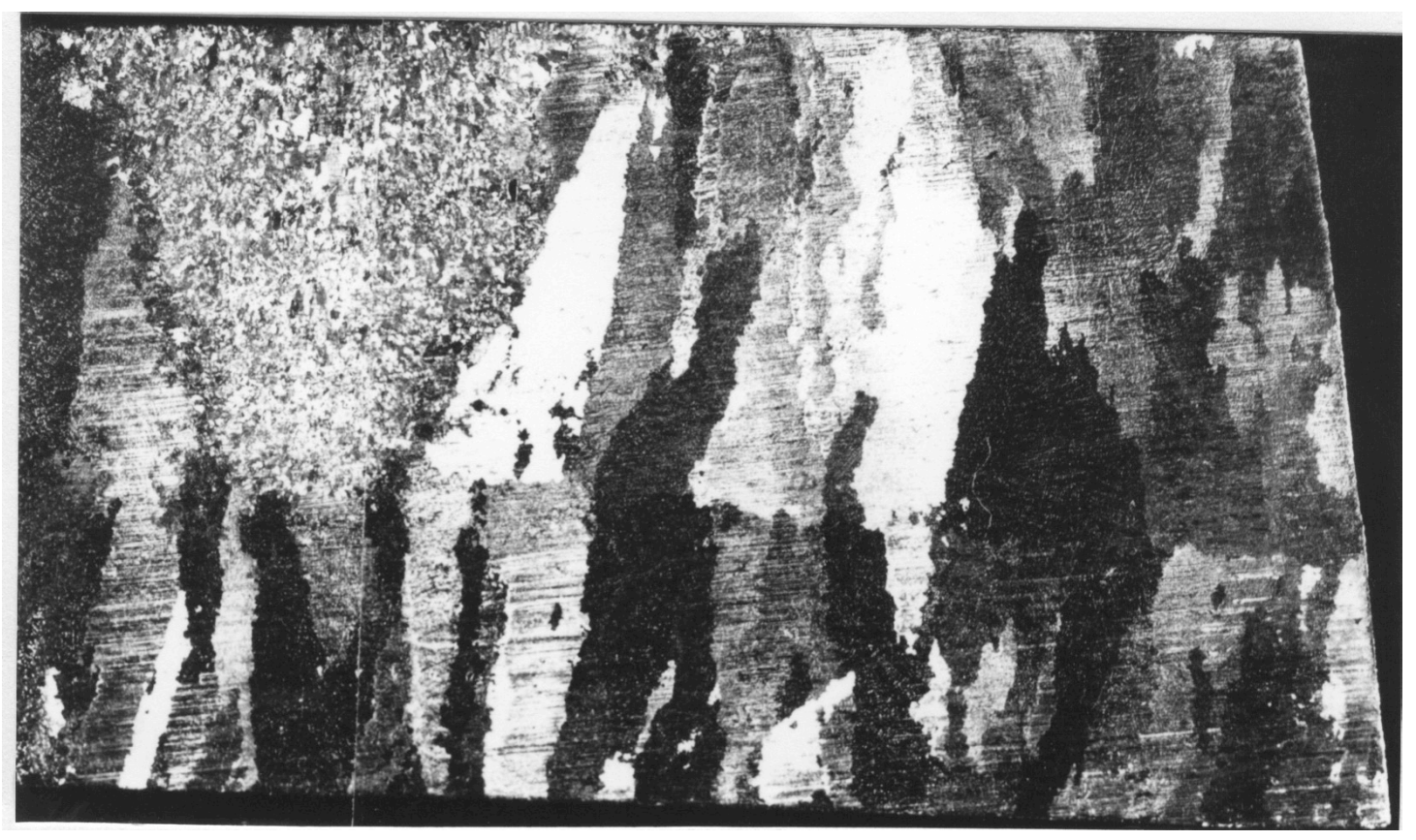

Figure 3. Microstructure along axial section of Loop B main shutoff valve from the Shippingport reactor. A repair weld is also seen on the outer diameter of the valve.

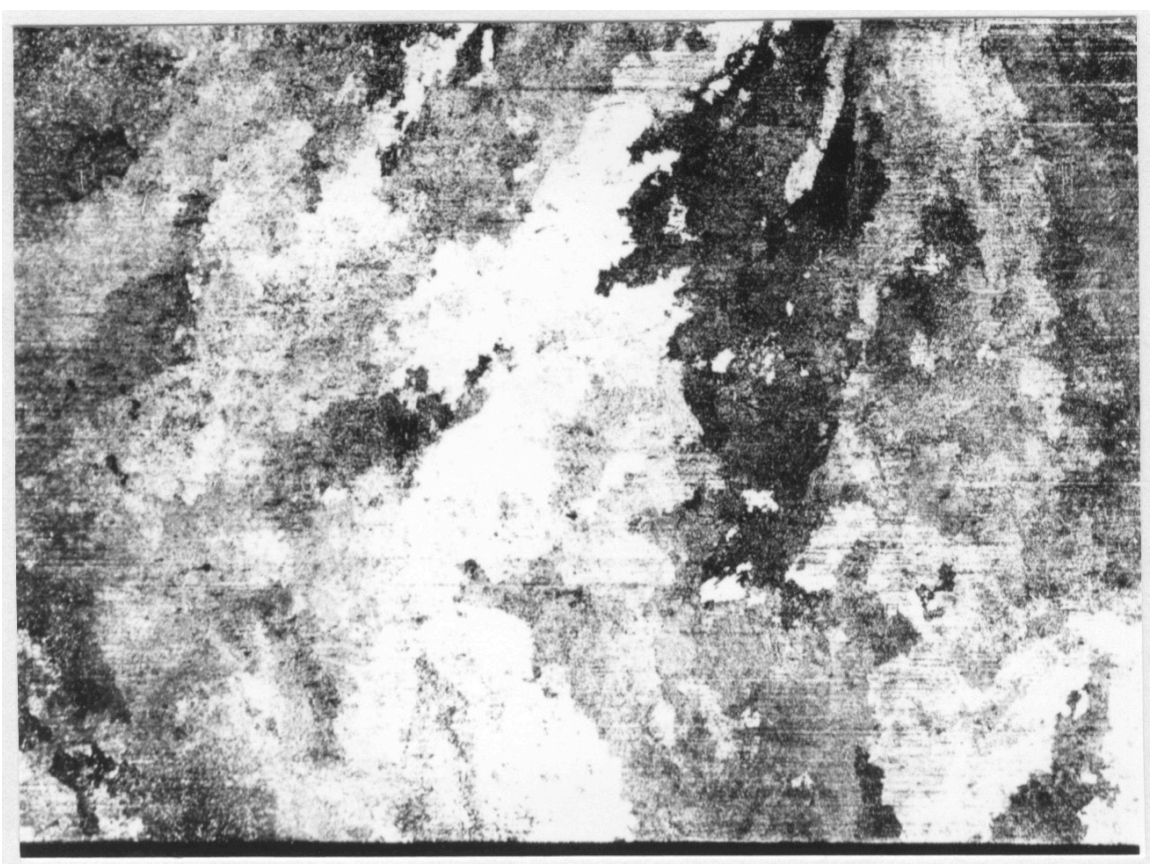

Figure 4. Microstructure along axial section of the spare volute from the Shippingport reactor 


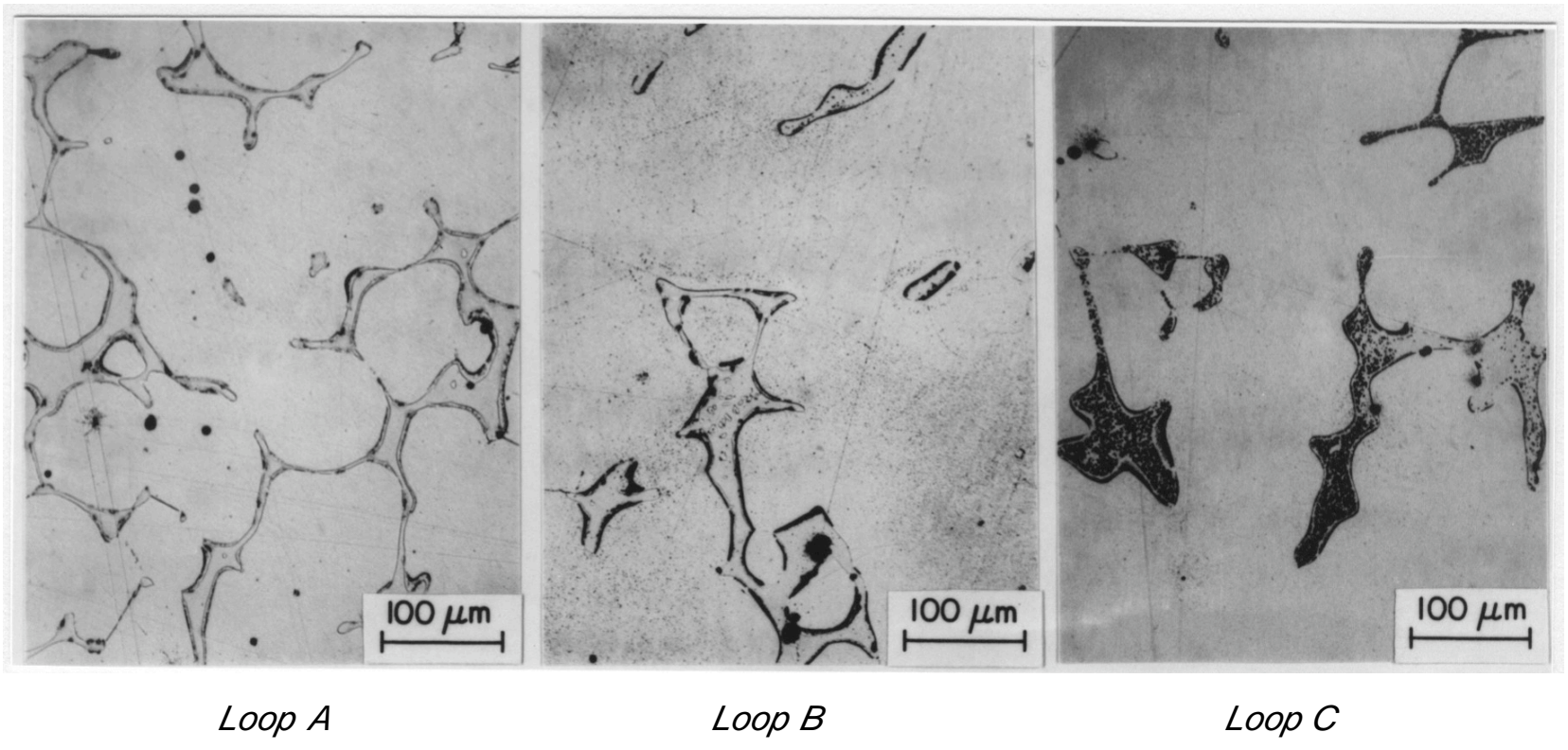

Figure 5. Ferrite morphology of cast materials from Loops $A, B$, and $C$ cold-leg check valves from the Shippingport reactor

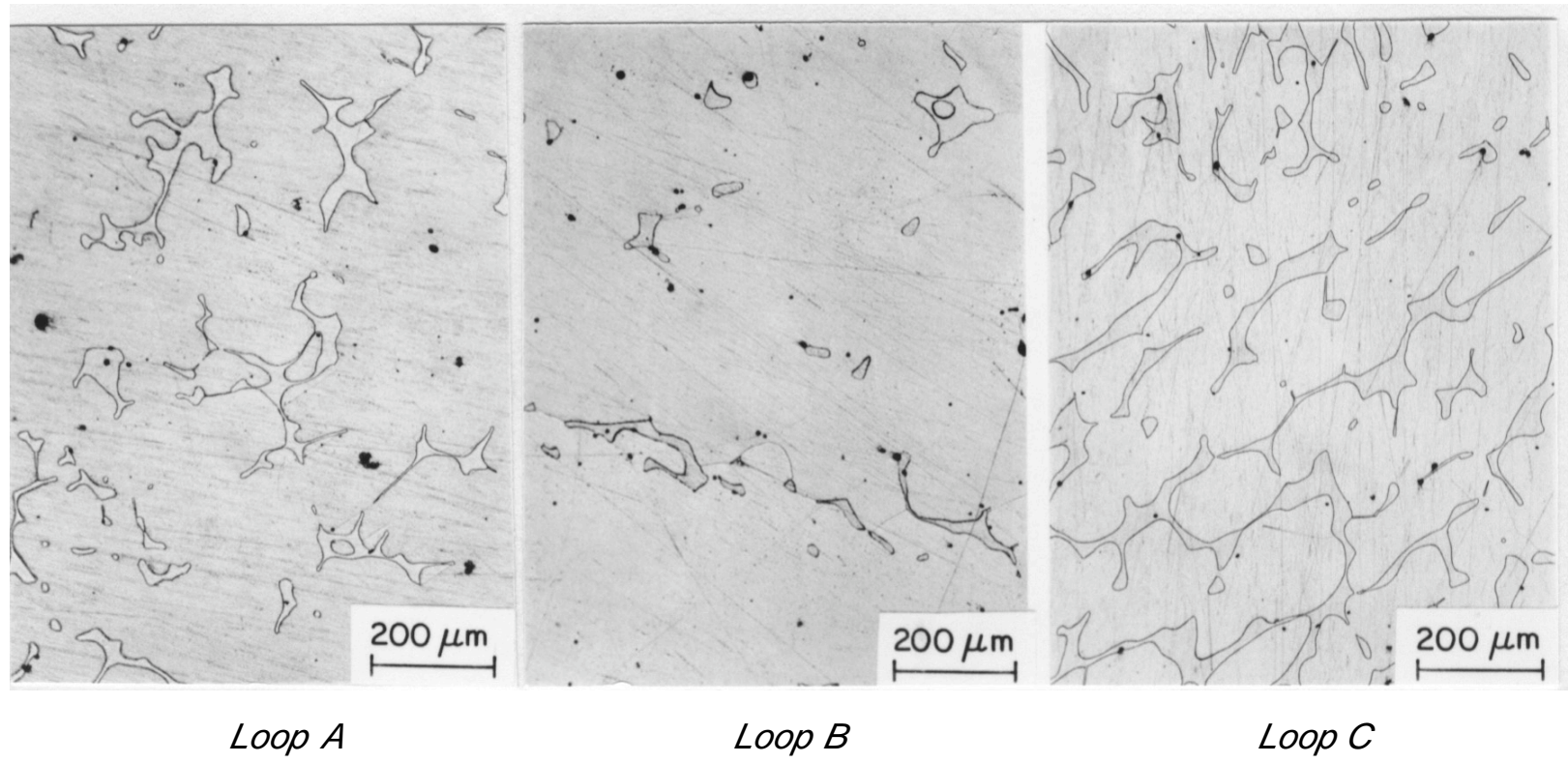

Figure 6. Ferrite morphology of cast materials from Loops A, B, and C hot-leg main shutoff valves from the Shippingport reactor 


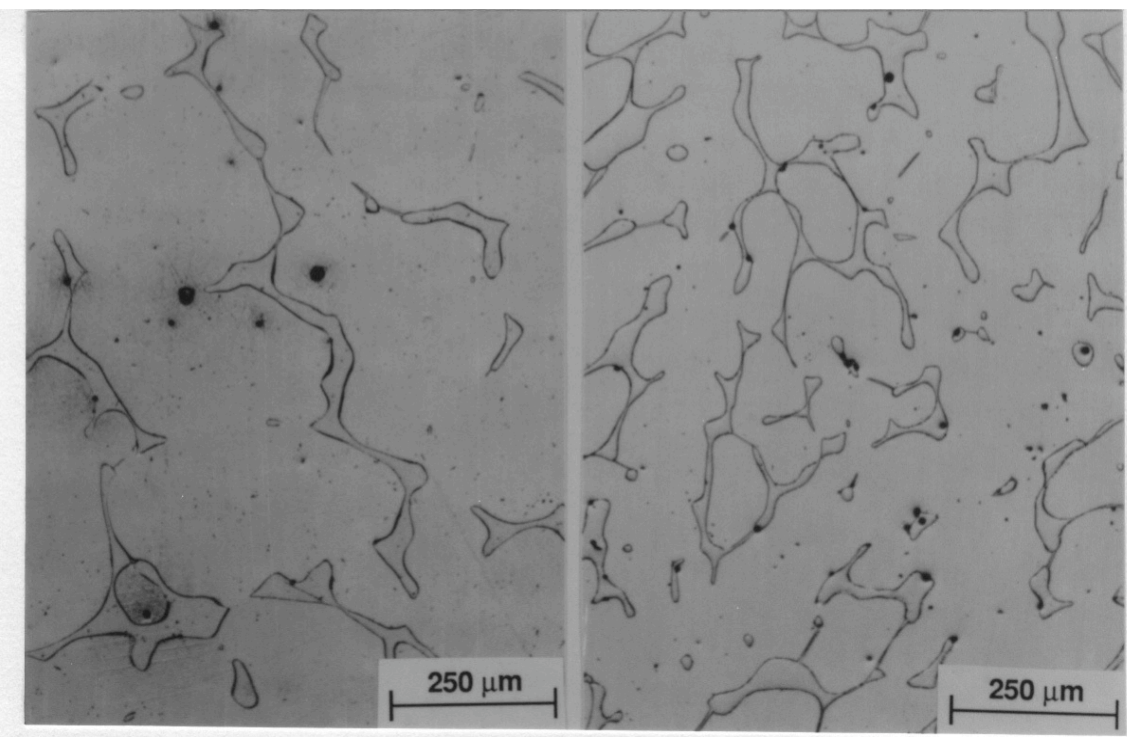

Cold-Leg Pump Volute

Spare Pump Volute

Figure 7. Ferrite morphology of cast materials from the cold-leg and spare pump volutes from the Shippingport reactor

precipitates on slip bands and stacking faults, was also observed in the austenite of the check valve material. Precipitation of $\sigma$ phase generally occurs at temperatures $>550^{\circ} \mathrm{C}\left(1022^{\circ} \mathrm{F}\right)$. The presence of $\sigma$ phase and phase-boundary migration indicate significant differences between the production heat treatment of the check valves and that of the other materials.

\section{Mechanical Properties}

Specimens for Charpy-impact, tensile, and fracture toughness tests were obtained from different locations across the thickness of the various components. All specimens were in the LC orientation. * Impact tests were conducted on standard Charpy V-notch specimens machined according to ASTM Specification E 23. A Dynatup Model 8000A drop-weight impact machine with an instrumented tup and data readout system was used for the tests. Tensile tests were performed on cylindrical specimens with a diameter of $5 \mathrm{~mm}$ and a gage length of $20 \mathrm{~mm}$. The tests were conducted at an initial strain rate of $4 \times 10^{-4} \mathrm{~s}^{-1}$. The fracture toughness J-R curve tests were conducted according to ASTM Specifications E 813-85 and E 1152-87. Compact-tension specimens, $25.4 \mathrm{~mm}$ thick, were used for the tests. The experimental procedure and test results for the Charpy-impact, tensile, and fracture toughness tests are given in Appendices A, B, and C, respectively. Preliminary results from this study have been presented earlier.20-22

\footnotetext{
* The first letter represents the direction normal to the plane of the crack; the second indicates the direction of crack propagation. $\mathrm{L}=$ longitudinal and $\mathrm{C}=$ circumferential.
} 


\subsection{Baseline Mechanical Properties}

The baseline mechanical properties for the unaged materials must be known to establish the effects of thermal aging during reactor service. Microstructural and annealing studies $3,4,18,19$ on laboratory- and reactor-aged materials have been conducted to investigate the possibility of recovering the mechanical properties of embrittled materials. The formation of the $\alpha^{\prime}$ phase by spinodal decomposition is the primary mechanism of thermal embrittlement. The $\alpha^{\prime}$ phase is not stable at temperatures $>550^{\circ} \mathrm{C}\left(1022^{\circ} \mathrm{F}\right)$. The mechanical properties can be recovered by annealing the embrittled cast stainless steels for $1 \mathrm{~h}$ at $550^{\circ} \mathrm{C}$ and then water quenching to dissolve the $\alpha^{\prime}$ phase while avoiding the formation of $\sigma$ phase.

The influence of annealing on the Charpy transition curves of three laboratory-aged heats and service-aged material from the KRB reactor is shown in Fig. 8. Heats 68, 69, and 75 were aged for $10,000 \mathrm{~h}$ at $400^{\circ} \mathrm{C}$ and the $\mathrm{KRB}$ pump cover plate was in service for $\approx 70,000$ at $284^{\circ} \mathrm{C}$. The Charpy-transition curve for the aged material is represented by dashed lines and open circles in Fig. 8. The thermally embrittled material was annealed for $1 \mathrm{~h}$ at $550^{\circ} \mathrm{C}$ and then water queched. The results indicate an essentially complete recovery from thermal embrittlement; the transition curves for the annealed materials agree well with those for the unaged steel. Microstructural examination of the annealed material showed no $\alpha$ phase, but the size and distribution of the $G$ phase were the same as in the aged material. ${ }^{18,19}$ The results indicate that baseline mechanical properties of unaged material can be determined from recovery-annealed material.

Charpy-impact tests were also conducted on material from a cooler region of the Shippingport Loop A main shutoff valve to obtain baseline properties. The Charpy transition curves of MA9 and recovery-annealed material from MA9 and MA1 are shown in Fig. 9. These materials are from the same valve, although MA9 is from a cooler region of the valve. The results indicate that the MA9 material suffered no thermal embrittlement; annealing had no effect on the transition curves. The results for annealed MA1 material also show good agreement with the transition curve for MA9. The upper-shelf energy (USE) of both materials is not constant but decreases with an increase in temperature. The average impact energies at room temperature and at $290^{\circ} \mathrm{C}\left(554^{\circ} \mathrm{F}\right)$, respectively, are 356 and $253 \mathrm{~J} / \mathrm{cm}^{2}$ for MA9, and 320 and $254 \mathrm{~J} / \mathrm{cm}^{2}$ for annealed MA1. The Charpy data were fitted with a hyperbolic tangent function of the form

$$
\mathrm{C}_{\mathrm{v}}=\mathrm{K}_{\mathrm{o}}+\mathrm{B}\left\{1+\tanh \left(\frac{\mathrm{T}-\mathrm{C}}{\mathrm{D}}\right)\right\}
$$

where $\mathrm{K}_{\mathrm{o}}$ is the lower-shelf energy, $\mathrm{T}$ is the test temperature in ${ }^{\circ} \mathrm{C}, \mathrm{B}$ is half the distance between the upper- and lower-shelf energy, $\mathrm{C}$ is the mid-shelf Charpy transition temperature (CTT) in ${ }^{\circ} \mathrm{C}$, and $\mathrm{D}$ is the half width of the transition region. The best-fit curves for MA9, with or without annealing, and for annealed MA1 indicate that the latter is marginally weaker; the CTT is $\approx 10^{\circ} \mathrm{C}$ higher and the average USE is $\approx 30 \mathrm{~J} / \mathrm{cm}^{2}$ lower for MA1. Such differences in impact energy are most likely due to minor variations in composition and structure of the materials from different locations of the casting. The Charpy data for MA9 and annealed MA1 may be represented by a single transition curve; the best-fit curve is shown in Fig. 9. 

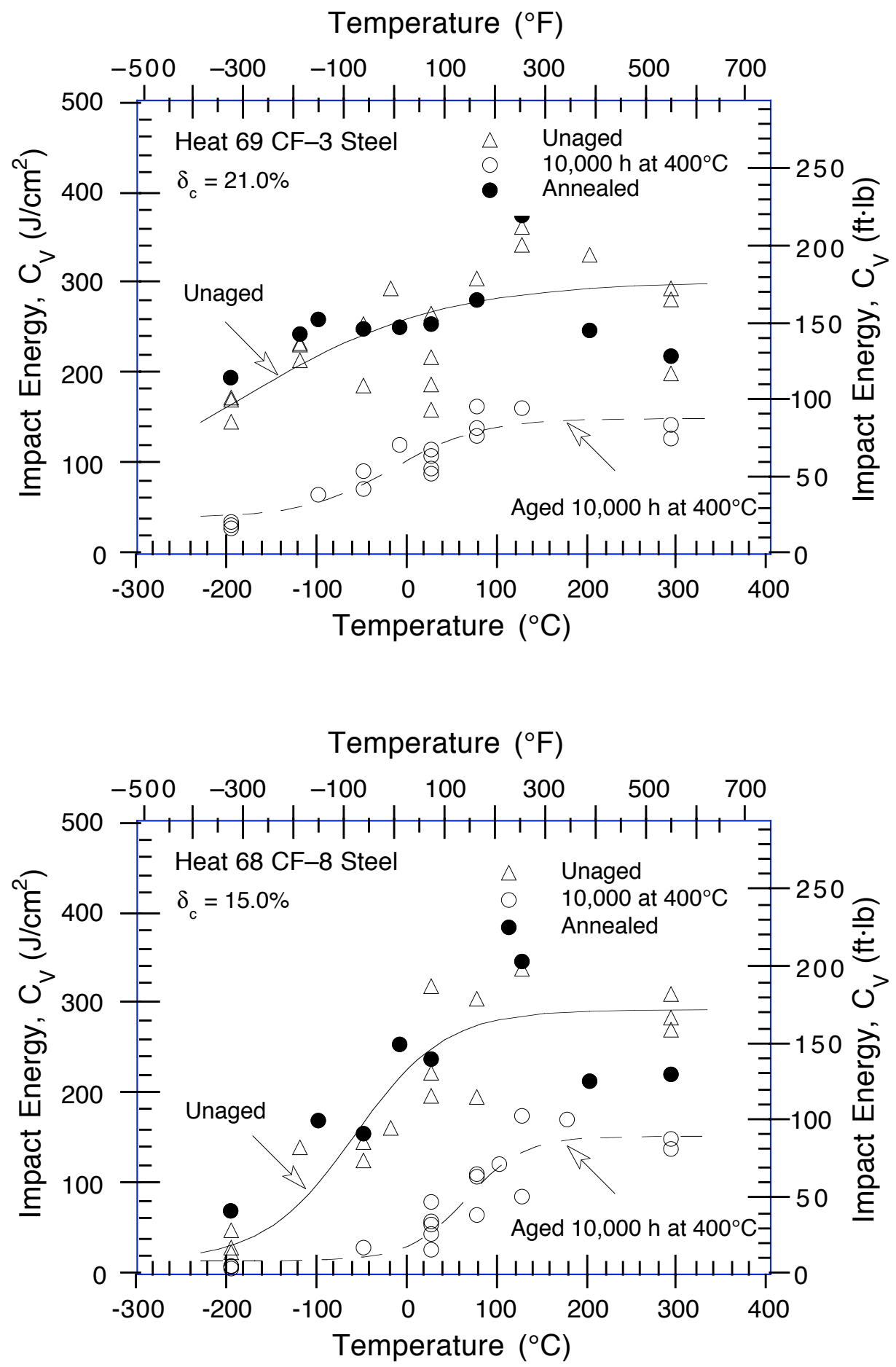

Figure 8. Effect of annealing for $1 \mathrm{~h}$ at $550^{\circ} \mathrm{C}$ and then water quenching on Charpy-transition curves for laboratory-aged Heats 69, 68, and 75 , and service-aged KRB pump cover plate. The dashed lines and open circles represent the transition curve before the annealing treatment. (Solid and dashed lines are best-fit curves.) 

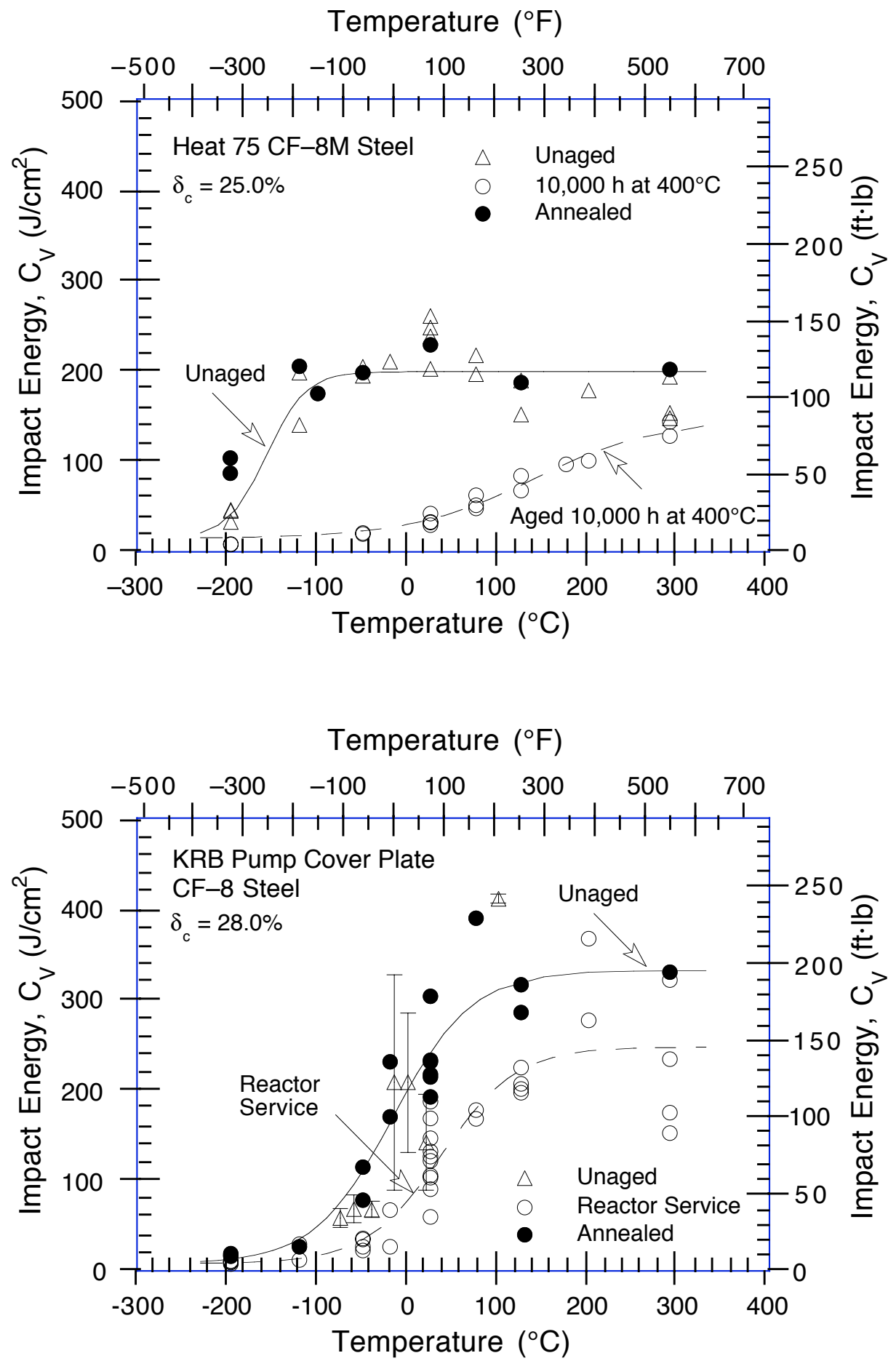

Figure 8. (Contd.) 


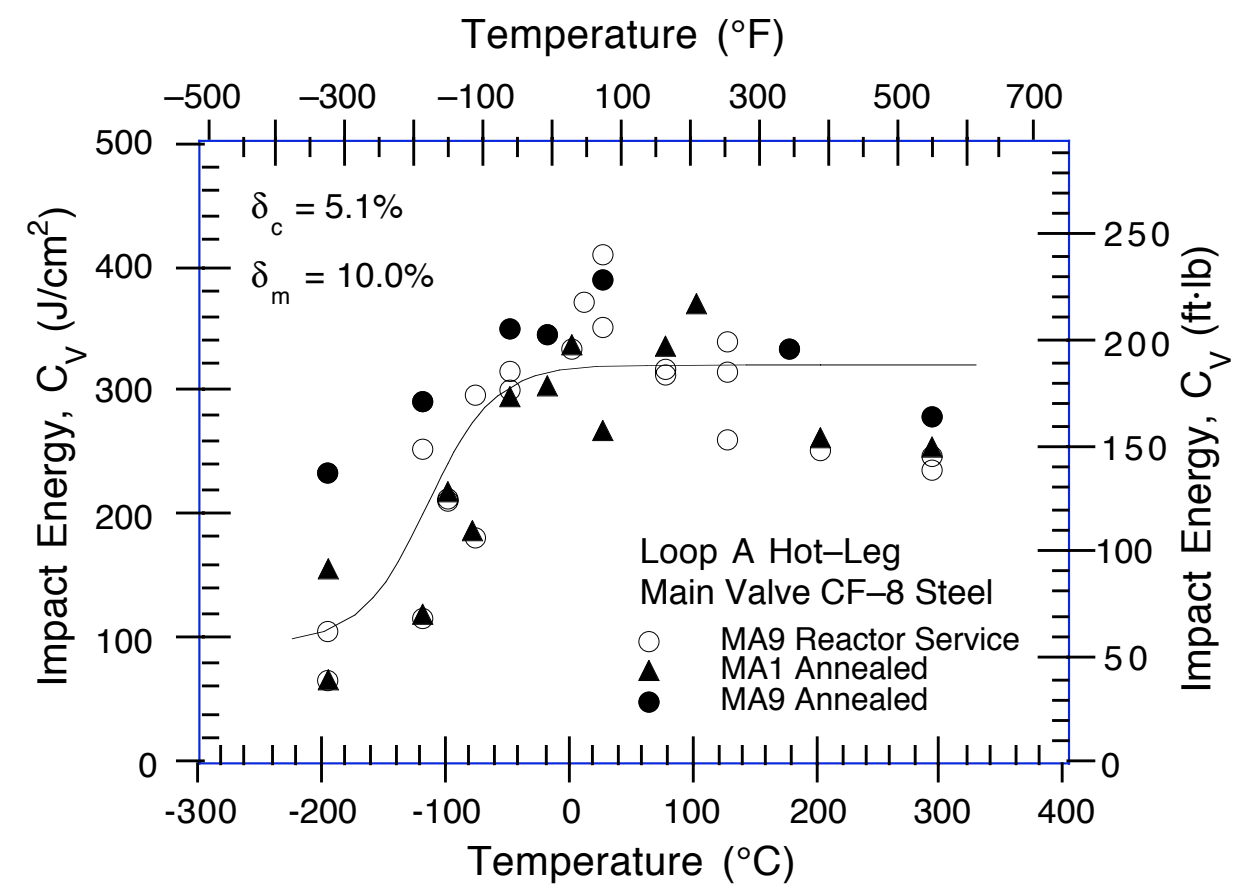

Figure 9. Effect of annealing on Charpy-transition curve of cast material from the hot-leg main shutoff valve. Material MA9 is from a cooler region of the valve. (Solid line is best-fit curve.)

\subsection{Charpy-Impact Energy}

Charpy impact data for the various cast materials from the Shippingport reactor are given in Appendix $A$ and the Charpy transition curves are shown in Figs. 10-12. The results for MA9 and recovery-annealed MA1 materials are shown as the baseline Charpy transition curve for MA1 in Fig. 10. The baseline transition curves for CA4 and PV are represented by the results for recovery-annealed materials. The Charpy data were fitted with the hyperbolic tangent expression given in Eq. 1; the values of the constants for the various materials are given in Table 2. The results indicate that the RT impact energy of the materials is relatively high and the mid-shelf CTT, i.e., constant $C$ in Eq. 1, is very low. The check valve materials CA4 and CB7 are weaker than MA1 and PV, e.g., the mid-shelf CTT is $\approx 100^{\circ} \mathrm{C}$ higher for CA4 and CB7. The higher CTTs are due to the presence of phase-boundary carbides in the check valve materials (Fig. 5). The carbides weaken the phase boundaries and thus promote failure by phase-boundary separation.

The decrease in impact strength from $\approx 13 \mathrm{y}$ of service at reactor temperatures is minimal for the materials. The RT Charpy-impact energy decreased from 188 to $145 \mathrm{~J} / \mathrm{cm}^{2}(111$ to $86 \mathrm{ft} \cdot \mathrm{lb})$ for check valve CA4, 320 to $299 \mathrm{~J} / \mathrm{cm}^{2}$ (189 to $176 \mathrm{ft} \cdot \mathrm{lb}$ ) for main valve MA1, and 424 to $322 \mathrm{~J} / \mathrm{cm}^{2}$ (250 to $190 \mathrm{ft} \cdot \mathrm{lb}$ ) for pump volute PV. The large difference in USE for the unaged and service-aged materials from Row 1 of MA1 (Fig. 10), is not due to thermal aging. The inner-15-mm region of the MA1 valve body contains a high density of inclusions/flaws and is inherently weak. The inner surface of all of the valves contained repair welds. However, no significant difference was noted in the chemical composition or ferrite content of the material across the thickness of the valve body. 
Table 2. Values of constants in Eq. 1 for Charpy transition curve of CF-8 cast SSs from the Shippingport reactor and KRB pump cover plate

\begin{tabular}{|c|c|c|c|c|c|c|}
\hline \multirow[b]{2}{*}{$\begin{array}{l}\text { Material } \\
\text { ID }\end{array}$} & \multicolumn{2}{|c|}{ Service Condition } & \multicolumn{4}{|c|}{ Constants } \\
\hline & $\begin{array}{l}\text { Temp., } \\
{ }^{\circ} \mathrm{C} \\
\end{array}$ & $\begin{array}{c}\text { Time, } \\
y\end{array}$ & $\begin{array}{c}\mathrm{K}_{\mathrm{o}} \\
\mathrm{J} / \mathrm{cm}^{2}\end{array}$ & $\begin{array}{c}\mathrm{B}, \\
\mathrm{J} / \mathrm{cm}^{2}\end{array}$ & $\begin{array}{l}\mathrm{C}, \\
{ }^{\circ} \mathrm{C}\end{array}$ & $\begin{array}{l}\mathrm{D}, \\
{ }^{\circ} \mathrm{C}\end{array}$ \\
\hline \multicolumn{7}{|c|}{ Cold-Leg Check Valves } \\
\hline CA4 & Annealed & - & 25 & 98.6 & -37.0 & 97.9 \\
\hline CA4 & 264 & 113,900 & 25 & 79.2 & -20.1 & 81.8 \\
\hline CB7 & 264 & 113,900 & 76 & 108.8 & 6.0 & 65.2 \\
\hline \multicolumn{7}{|c|}{$\underline{\text { Hot-Leg Main Shutoff Valve }}$} \\
\hline MA9a & Annealed & - & 96 & 112.0 & -116.3 & 54.1 \\
\hline MA9 & $<200$ & 113,900 & 83 & 110.1 & -110.7 & 48.3 \\
\hline MA9 & 400 & 10,000 & 10 & 90.8 & -23.6 & 127.8 \\
\hline$M A 1 / 23^{a}$ & Annealed & & 96 & 112.0 & -116.3 & 54.1 \\
\hline$M A 1 / 23^{b}$ & 281 & 113,900 & 73 & 87.6 & -114.2 & 29.8 \\
\hline $\mathrm{MA} 1 / 1^{\mathrm{c}}$ & 281 & 113,900 & 69 & 63.7 & -137.0 & 38.6 \\
\hline \multicolumn{7}{|c|}{ Pump Volutes } \\
\hline PV & Annealed & - & 150 & 116.2 & -151.9 & 109.7 \\
\hline PV & 264 & 113,900 & 75 & 109.4 & -141.9 & 49.5 \\
\hline VR & Unaged & - & 61 & 88.1 & -112.4 & 38.5 \\
\hline VR & 400 & 10,000 & 23 & 46.3 & 14.5 & 91.2 \\
\hline \multicolumn{7}{|c|}{ Pump Cover Plate } \\
\hline KRB & Annealed & - & 8 & 161.9 & -16.5 & 87.2 \\
\hline KRB & 284 & 8 & 8 & 119.7 & 36.8 & 83.2 \\
\hline
\end{tabular}

a Determined from combined data for MA9 and annealed MA9 and MA1.

b Material from Rows 2 \& 3, which corresponds to 15-45-mm region of the wall.

c Material from Row 1, which corresponds to inner-5-mm region of the wall.

d Obtained from the KRB reactor in Gundremmingen, Germany.

Unaged material from the spare pump volute and MA9 material from cooler regions of the main shutoff valve were aged in the laboratory for $10,000 \mathrm{~h}$ at $400^{\circ} \mathrm{C}$; the results are shown in Fig. 13. Both steels show a significant decrease in impact energy after thermal aging. The USE decreases from $\approx 320$ to $190 \mathrm{~J} / \mathrm{cm}^{2}$ for MA9 and from $\approx 235$ to $115 \mathrm{~J} / \mathrm{cm}^{2}$ for VR material. The mid-shelf CTT increases by 90 and $120^{\circ} \mathrm{C}$ for MA9 and VR materials, respectively. These curves represent the saturation condition, i.e., the minimum Charpy-impact energy that would be achieved by these materials after long-term aging.

\subsection{Tensile Properties}

Tensile tests were conducted at room temperature and at $290^{\circ} \mathrm{C}$ on service-aged materials from the Loop A cold-leg check valve and pump volute and from the hot-leg main shutoff valve; results are given in Appendix $B$. The results indicate that thermal aging during $\approx 15 \mathrm{y}$ of reactor service had no effect on yield stress and that the increase in ultimate stress is minimal for the three materials. 

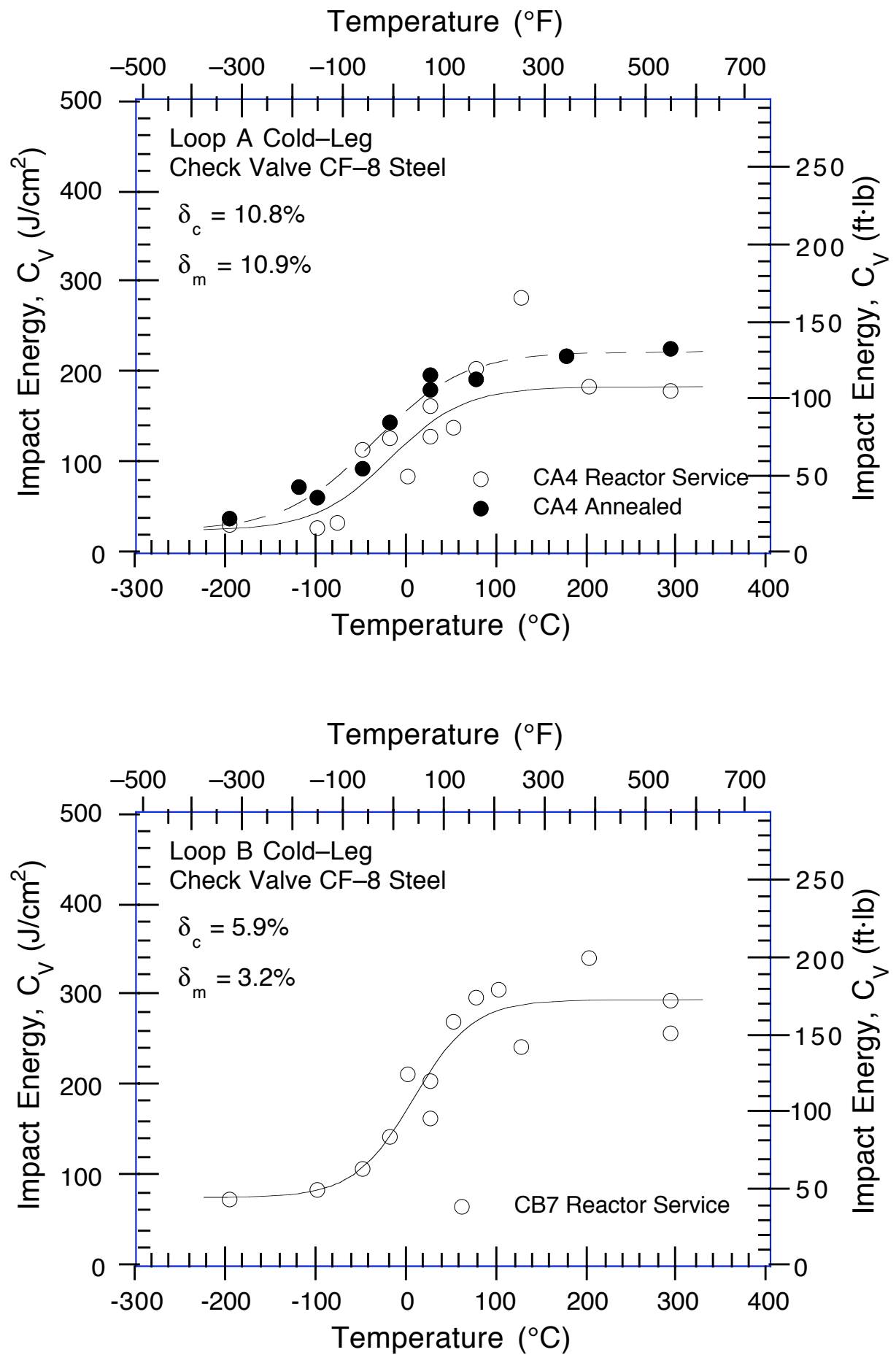

Figure 10. Charpy transition curves for Loop $A$ and $B$ cold-leg check valves after $13 y$ of service at $264^{\circ} \mathrm{C}$. (Solid and dashed lines represent best-fit curves for service-aged and annealed materials, respectively.) 

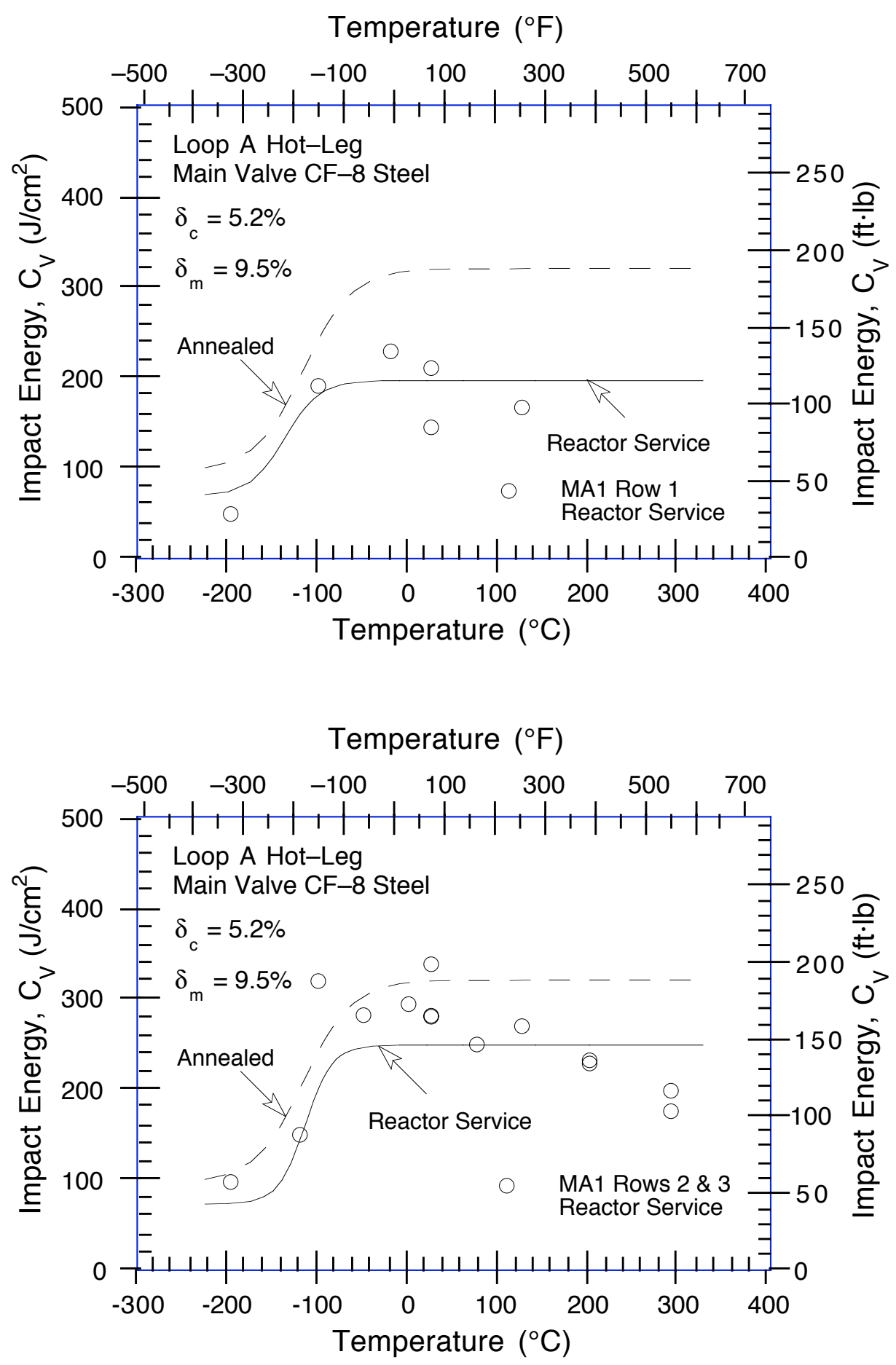

Figure 11. Charpy transition curves for Loop A hot-leg main shutoff valve after $13 y$ of service at $281^{\circ} \mathrm{C}$. Row 1 corresponds to inner 15- $\mathrm{mm}$ region and rows 2 and 3 represent 15- to 50- $\mathrm{mm}$ region of the valve body. (Solid and dashed lines are best-fit curves.) 


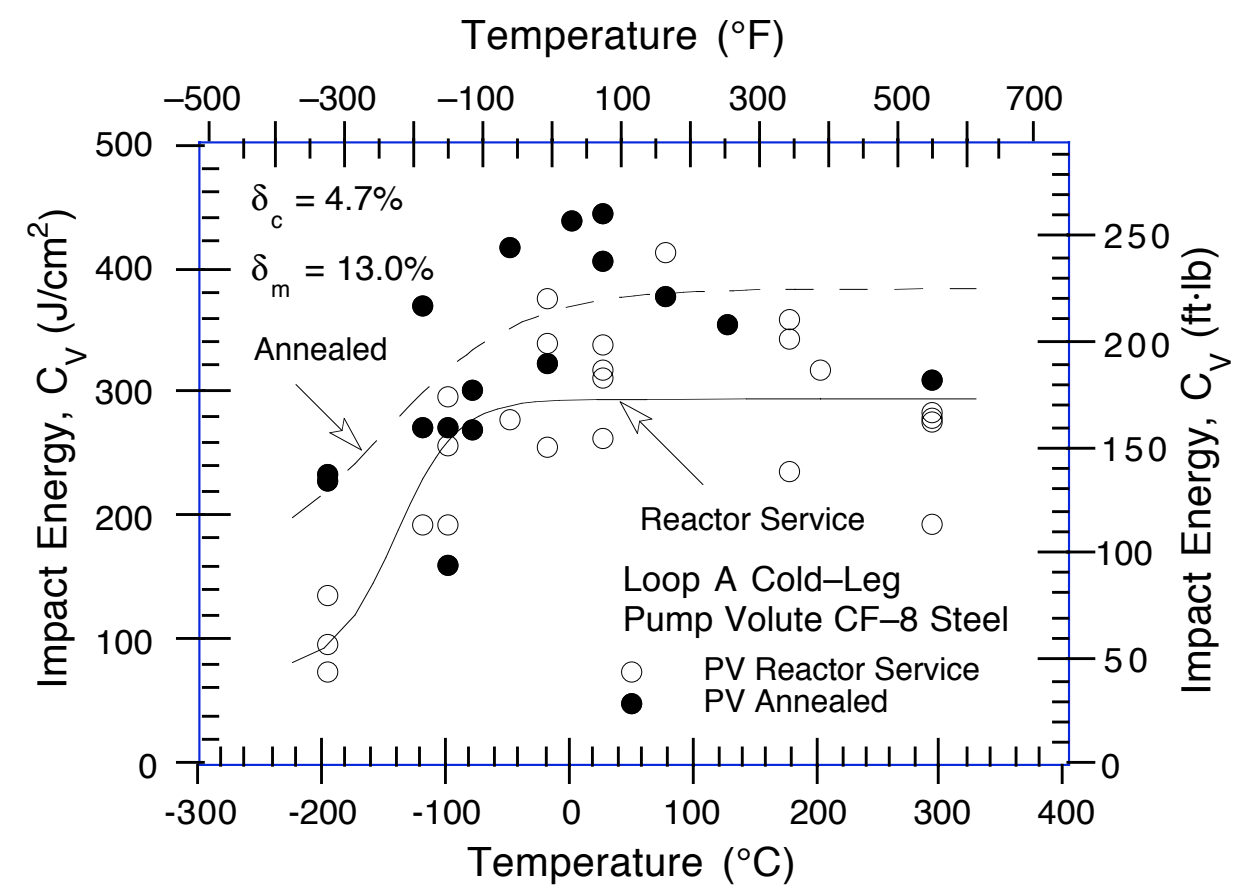

Figure 12. Charpy transition curves for Loop A pump volute after $13 y$ of service at $264^{\circ} \mathrm{C}$. (Solid and dashed lines represent best-fit curves for service-aged and annealed materials, respectively.)

Tensile properties were also estimated from the instrumented Charpy-impact test data. ${ }^{1,2,4}$ For a Charpy specimen, yield stress is given by

$$
\sigma_{\mathrm{y}}=1.50 \mathrm{P}_{\mathrm{y}}\left(\frac{\mathrm{B}}{\mathrm{Wb}^{2}}\right)
$$

and ultimate stress by

$$
\sigma_{\mathrm{u}}=2.28 \mathrm{P}_{\mathrm{m}}\left(\frac{\mathrm{B}}{\mathrm{Wb}^{2}}\right)
$$

where $\mathrm{Py}$ and $\mathrm{Pm}$ are the yield and maximum loads obtained from the load-time traces of the instrumented Charpy-impact test, $\mathrm{W}$ is the specimen width, $\mathrm{B}$ is the specimen thickness, and $\mathrm{b}$ is the uncracked ligament.23 The estimated values of yield and ultimate stress, the values obtained from tensile tests, and estimated tensile stresses for recovery-annealed materials are shown in Figs. 14 and 15. For all of the materials, the estimated tensile properties are in good agreement with measured values. The tensile strength of CA4, PV, and MA1 materials is comparable. Two specimens of MA1 (Fig. 15) showed low ultimate strength (and also poor ductility). These specimens were obtained from the inner-15- $\mathrm{mm}$ region of the valve body. The poor tensile properties are caused by inclusions in the material. As discussed above, the RT impact energy of Row 1 specimens is also low, e.g., $\approx 177 \pm 33 \mathrm{~J} / \mathrm{cm}^{2}$, compared with $\approx 299$ $\pm 33 \mathrm{~J} / \mathrm{cm}^{2}$ for specimens from other regions of the valve body. 

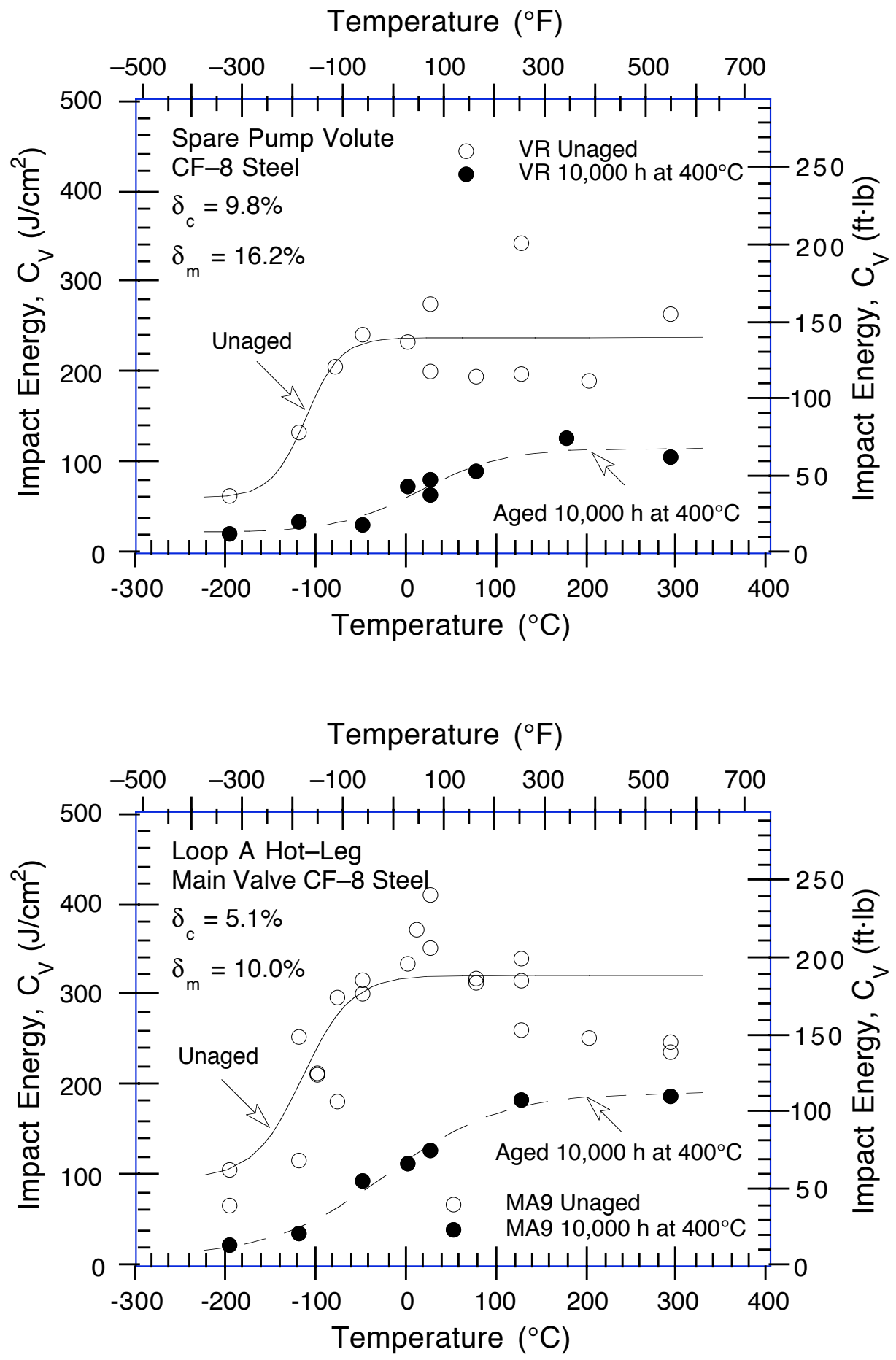

Figure 13. Charpy transition curves for materials from the spare pump volute and cooler region of the main shutoff valve before and after aging for $10,000 \mathrm{~h}$ at $400^{\circ} \mathrm{C}$. (Solid and dashed lines represent unaged and aged materials, respectively.) 

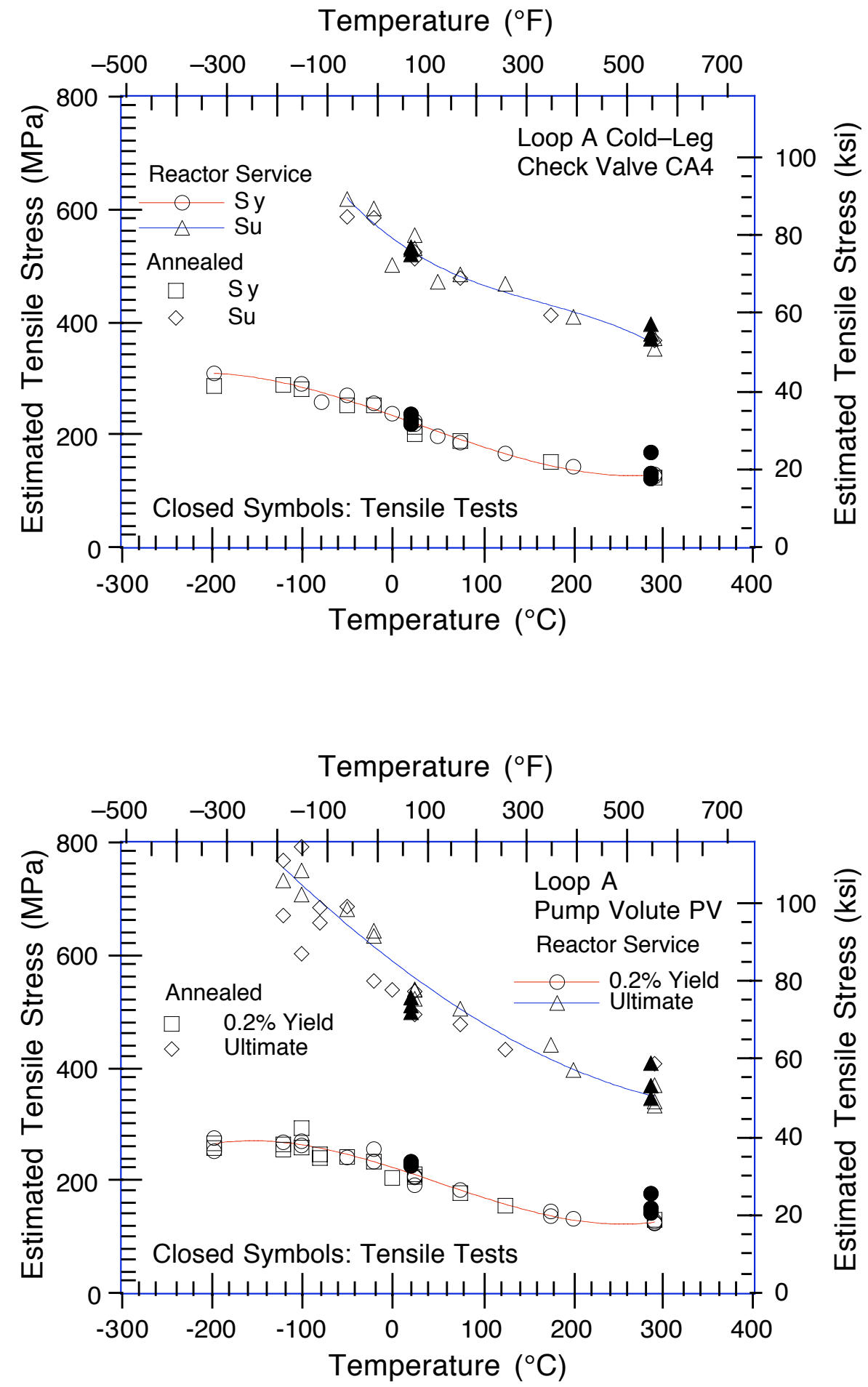

Figure 14. Yield and ultimate stresses estimated from Charpy-impact data and obtained from tensile tests for cold-leg check valve and pump volute, and estimated tensile stresses of annealed materials 

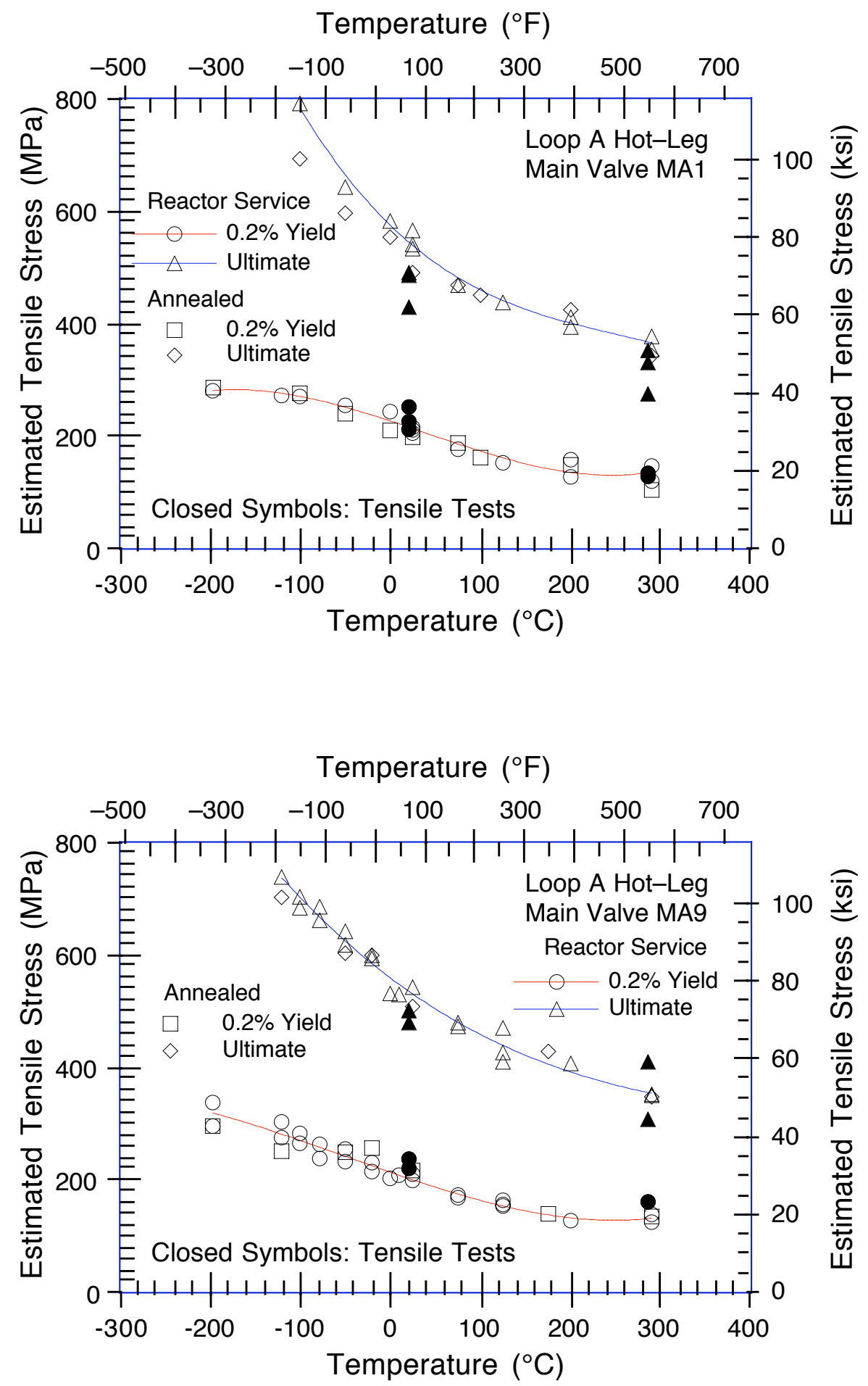

Figure 15. Yield and ultimate stresses estimated from Charpy-impact data and obtained from tensile tests for hot-leg main valve, and estimated tensile stresses of annealed materials. Material MA9 is from a cooler region of the valve. 
Tensile tests were also conducted on MA9 and VR materials before and after aging for $10,000 \mathrm{~h}$ at $400^{\circ} \mathrm{C}$. The experimental values of yield and ultimate stress and values estimated from the Charpy-impact data are shown in Fig. 16. These curves represent the saturation condition, i.e., the maximum increase in tensile strength achieved by these materials after long-term aging. The results indicate that, for both steels, the increase in yield stress is minimal and ultimate stress is increased by $\approx 4 \%$ for MA9 and by $\approx 15 \%$ for VR.

\subsection{Fracture Toughness}

Fracture toughness $\mathrm{J}-\mathrm{R}$ curve tests were conducted at room temperature and $290^{\circ} \mathrm{C}$ on materials from the cold-leg check valve and pump volute, hot-leg main shutoff valve, and the spare pump volute; results are given in Appendix C. The test data, as well as an analysis and qualification of the data, are also presented in Appendix C. The baseline J-R curves for unaged materials were obtained from tests on material from cooler regions of the component, e.g., material MA9, or from material that was annealed for $1 \mathrm{~h}$ at $550^{\circ} \mathrm{C}$ and water quenched to recover the aging degradation. Tests were also conducted on materials that were aged further in the laboratory for $10,000 \mathrm{~h}$ at $400^{\circ} \mathrm{C}$ to determine the saturation fracture toughness, i.e., the minimum toughness that will be achieved for the specific materials after long-term service.

The effect of thermal aging, either during service or in the laboatory, on the fracture toughness $\mathrm{J}-\mathrm{R}$ curves of the various materials are shown in Figs. 17-20. The $\mathrm{J}-\mathrm{R}$ curves are expressed by the power-law relation $J_{d}=D(\Delta a)^{n}$ per ASTM Specifications E 813-85 and E 1152-87. The results indicate that the decrease in fracture toughness from reactor service is relatively small because of the low operating temperatures and/or low ferrite content of the materials. Even the decrease in toughness at saturation is minimal for these materials, particularly at $290^{\circ} \mathrm{C}$. Only the saturation RT J-R curves for materials from pump volute PV and spare volute VR show a significant change in fracture toughness.

\section{Estimation of Mechanical Properties}

A procedure and correlations have been developed for estimating mechanical properties of cast SS components during reactor service from known material information.7,8 A flow diagram for estimating Charpy-impact energy and fracture toughness J-R curves of cast SS components is shown in Fig. 21. Section B of Fig. 21 describes the estimation of Charpy-impact energy and fracture toughness J-R curves at "saturation," i.e., the minimum impact energy and fracture toughness that would be achieved for the material after long-term aging. The only information needed for these estimations is the chemical composition of the material. Estimation of mechanical properties at any given time and temperature of service is described in Section $C$ of Fig. 21. The initial impact energy of the unaged material is required for these estimations. $A$ detailed description of the procedure and the correlations for estimating Charpy-impact, fracture toughness, and tensile properties of cast SS have been presented elsewhere;6-8 for convenience, the correlations are repeated in the following sections.

\subsection{Charpy-Impact Energy}

When a certified materials test record (CMTR) is available, the saturation RT impact energy of a specific cast SS is determined from the chemical composition and ferrite content of the 

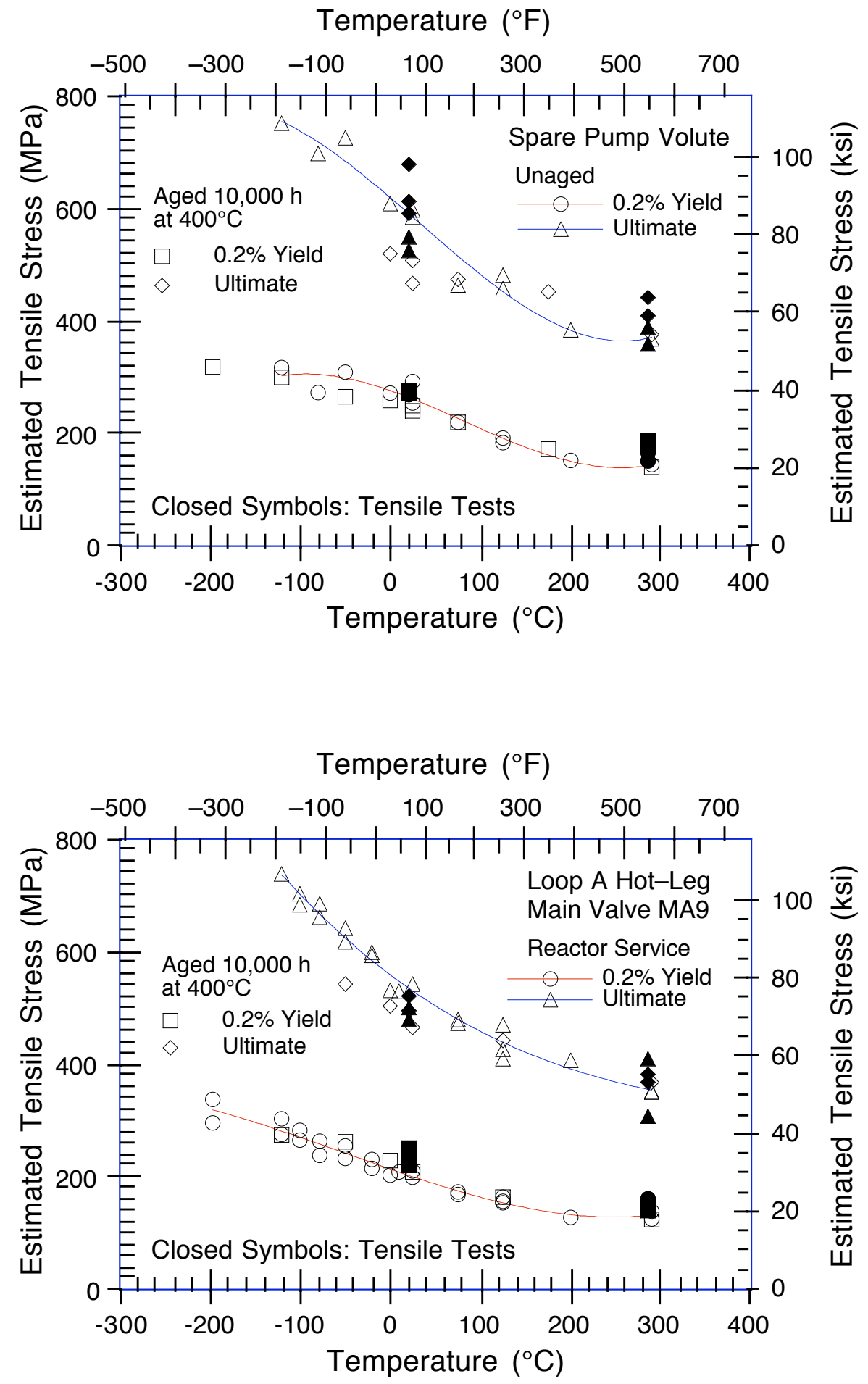

Figure 16. Yield and ultimate stresses estimated from Charpy-impact data and obtained from tensile tests for spare pump volute and hot-leg main valve before and after aging for $10,000 \mathrm{~h}$ at $400^{\circ} \mathrm{C}$ 

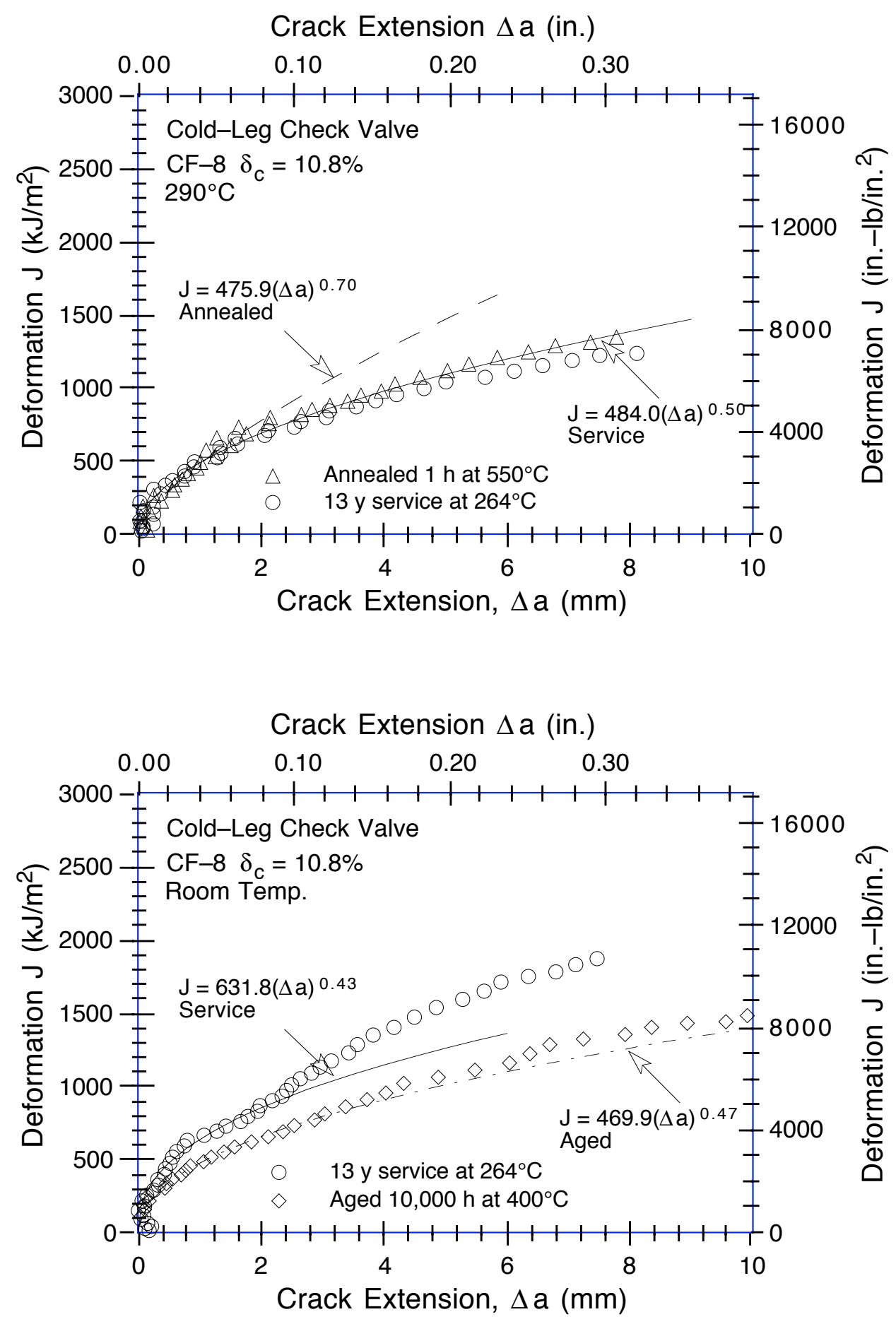

Figure 17. Fracture toughness $\mathrm{J}-R$ curves at room temperature and $290^{\circ} \mathrm{C}$ for annealed, service-aged, and laboratory-aged material from the cold-leg check valve. (Dashed, solid, and chain-dot lines are the best-fit power-law $\mathrm{J}-R$ curves for the annealed, service-aged, and laboratory-aged materials, respectively.) 

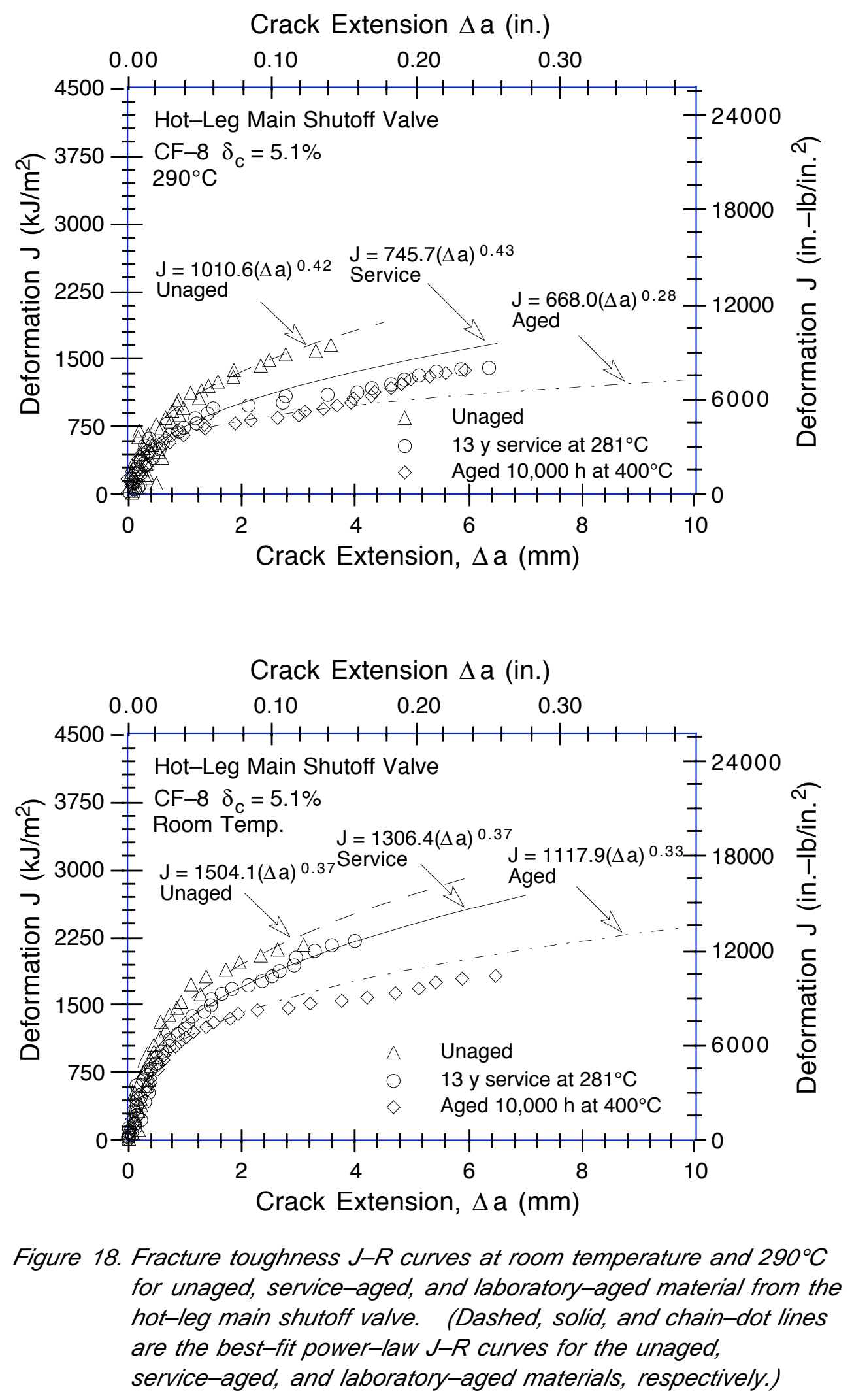

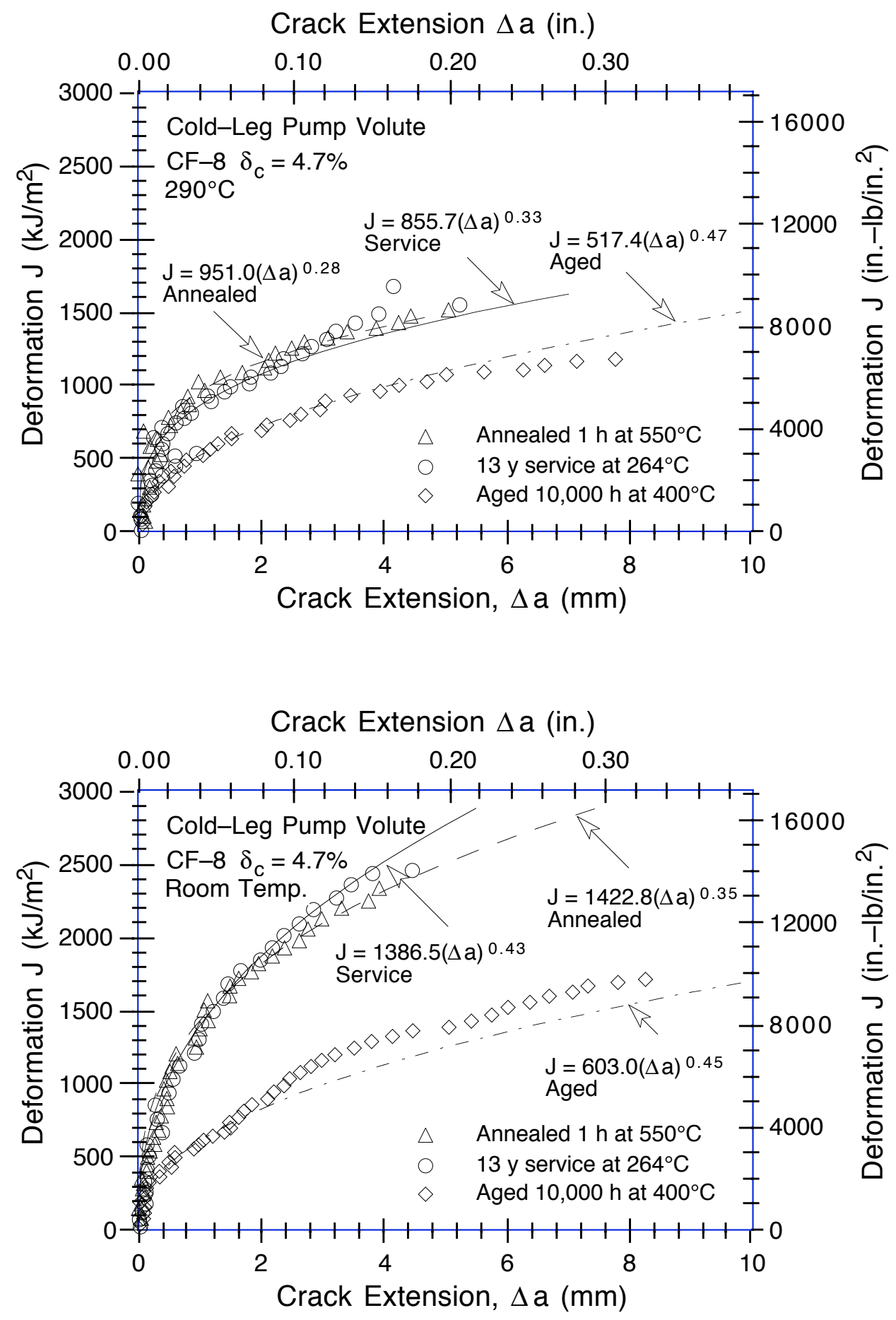

Figure 19. Fracture toughness $\mathrm{J}-R$ curves at room temperature and $290^{\circ} \mathrm{C}$ for annealed, service-aged, and laboratory-aged material from the cold-leg pump volute. (Dashed, solid, and chain-dot lines are the best-fit power-law J-R curves for the annealed, service-aged, and laboratory-aged materials, respectively.) 

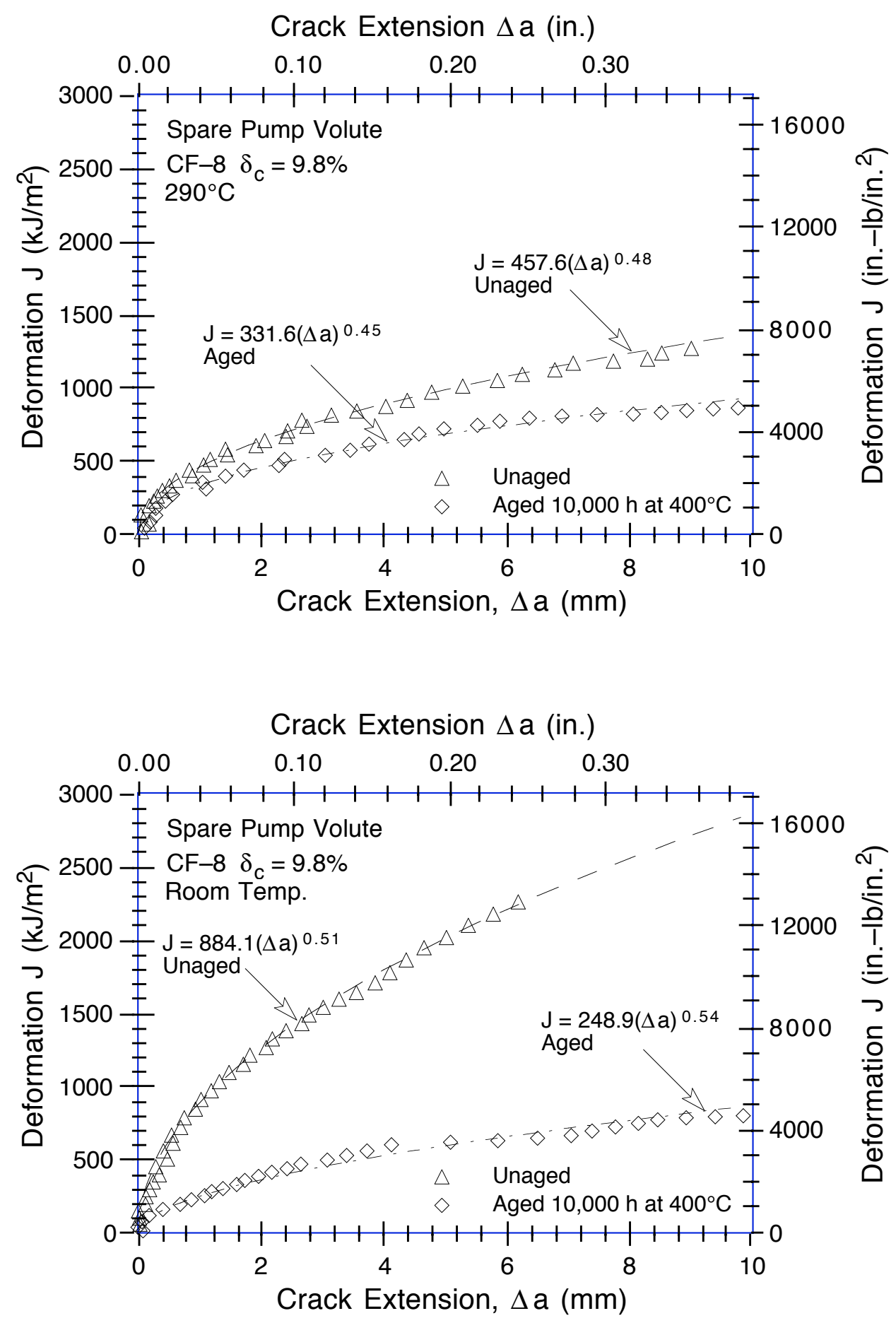

Figure 20. Fracture toughness $\mathrm{J}-R$ curves at room temperature and $290^{\circ} \mathrm{C}$ for unaged and laboratory-aged material from the spare pump volute. (Dashed and chain-dot lines are the best-fit power-law $J-R$ curves for the unaged and laboratory-aged materials, respectively.) 


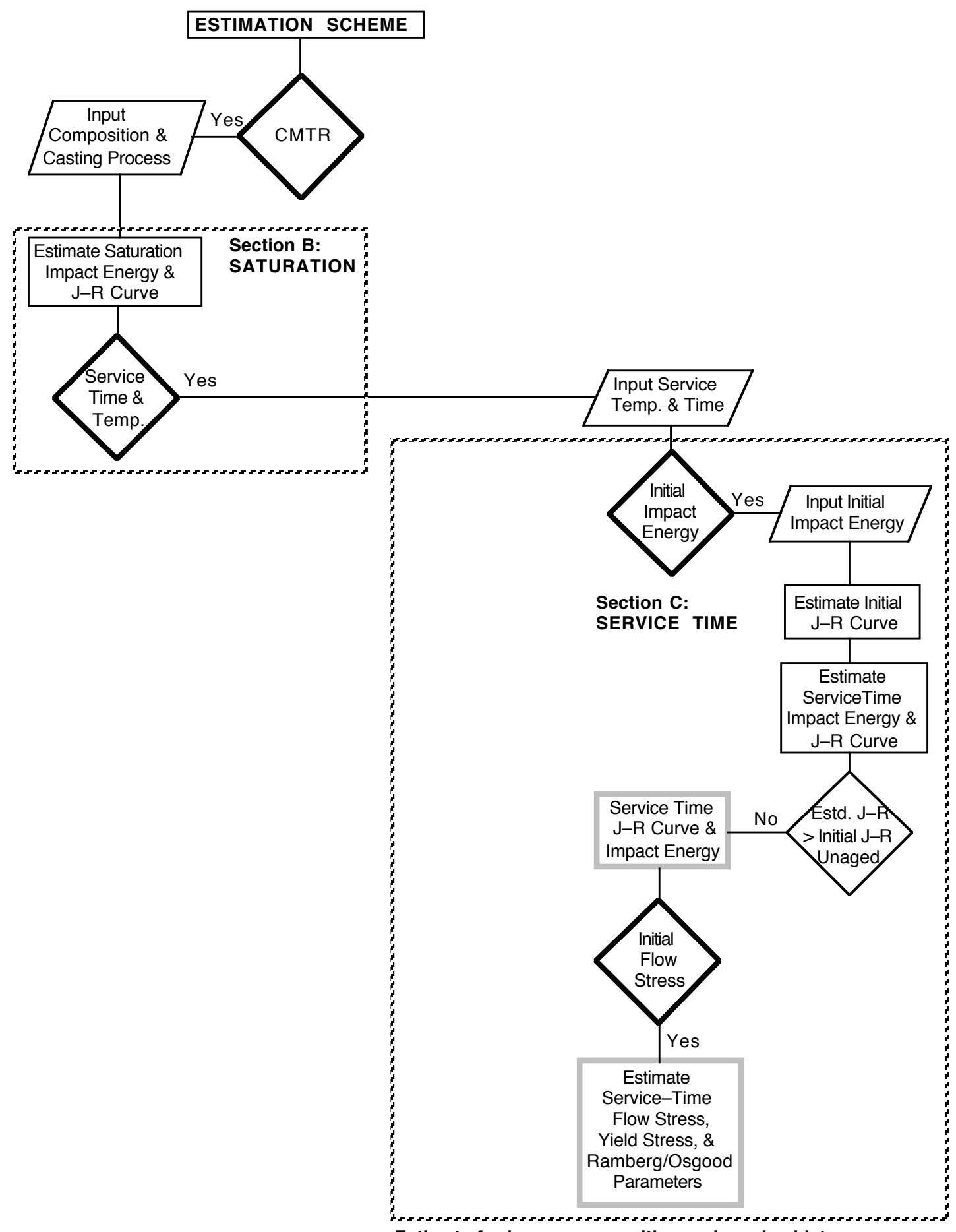

Estimate for known composition and service history

Figure 21. Flow diagram for estimating mechanical properties of cast materials obtained from the Shippingport reactor 
material. The ferrite content is calculated from chemical composition in terms of the Hull's equivalent factors 24

$$
\mathrm{Cr}_{\text {eq }}=\mathrm{Cr}+1.21(\mathrm{Mo})+0.48(\mathrm{Si})-4.99
$$

and

$$
\mathrm{Ni}_{\text {eq }}=(\mathrm{Ni})+0.11(\mathrm{Mn})-0.0086(\mathrm{Mn})^{2}+18.4(\mathrm{~N})+24.5(\mathrm{C})+2.77
$$

The ferrite content $\delta_{\mathrm{c}}$ is given by

$$
\delta_{\mathrm{c}}=100.3\left(\mathrm{Cr}_{\text {eq }} / \mathrm{Ni}_{\mathrm{eq}}\right)^{2}-170.72\left(\mathrm{Cr}_{\mathrm{eq}} / \mathrm{Ni} \text { eq }\right)+74.22
$$

The saturation RT impact energy for a specific cast SS is determined by two expressions, and the lower value is used for estimating fracture properties. For CF-3 and CF-8 steels, the saturation value of $\mathrm{RT}$ impact energy $\mathrm{C}_{V \text { sat }}$ is the lower value determined from

$$
\log _{10} \mathrm{C}_{\text {Vsat }}=1.15+1.36 \exp (-0.035 \Phi) \text {, }
$$

where the material parameter $\Phi$ is expressed as

$$
\Phi=\delta_{C}(C r+S i)(C+0.4 N)
$$

and from

$$
\begin{aligned}
\log _{10} \mathrm{CV}_{\text {Vsat }}= & 5.64-0.006 \delta_{\mathrm{C}}-0.185 \mathrm{Cr}+0.273 \mathrm{Mo}-0.204 \mathrm{Si} \\
& +0.044 \mathrm{Ni}-2.12(\mathrm{C}+0.4 \mathrm{~N})
\end{aligned}
$$

For CF-8M steel with $<10 \% \mathrm{Ni}$, the saturation value of $\mathrm{RT}$ impact energy $\mathrm{C}_{\mathrm{V} \text { sat }}$ is the lower value determined from

$$
\log _{10} \mathrm{C}_{\text {vsat }}=1.10+2.12 \exp (-0.041 \Phi)
$$

where the material parameter $\Phi$ is expressed as

$$
\Phi=\delta_{C}(N i+S i+M n)^{2}(C+0.4 N) / 5
$$

and from

$$
\begin{aligned}
\log _{10} \mathrm{C}_{\text {Vsat }}= & 7.28-0.011 \delta_{\mathrm{C}}-0.185 \mathrm{Cr}-0.369 \mathrm{Mo}-0.451 \mathrm{Si} \\
& -0.007 \mathrm{Ni}-4.71(\mathrm{C}+0.4 \mathrm{~N})
\end{aligned}
$$

For CF-8M steel with $>10 \% \mathrm{Ni}$, the saturation value of $\mathrm{RT}$ impact energy $\mathrm{C}_{\mathrm{V} \text { sat }}$ is the lower value determined from

$$
\log _{10} C_{V s a t}=1.10+2.64 \exp (-0.064 \Phi)
$$

where the material parameter $\Phi$ is expressed as 


$$
\Phi=\delta_{C}(N i+S i+M n)^{2}(C+0.4 N) / 5
$$

and from

$$
\begin{aligned}
\log _{10} \mathrm{C}_{\text {Vsat }}= & 7.28-0.011 \delta_{\mathrm{C}}-0.185 \mathrm{Cr}-0.369 \mathrm{Mo}-0.451 \mathrm{Si} \\
& -0.007 \mathrm{Ni}-4.71(\mathrm{C}+0.4 \mathrm{~N})
\end{aligned}
$$

If not known, the $\mathrm{N}$ content can be assumed to be $0.04 \mathrm{wt} \%$. The RT impact energy as a function of time and temperature of aging of a specific cast SS is determined from its estimated RT saturation impact energy $\mathrm{C}_{V \text { sat }}$ and the kinetics of embrittlement. The decrease in RT Charpy-impact energy $\mathrm{C}_{V}$ with time is expressed as

$$
\log _{10} \mathrm{C}_{\mathrm{v}}=\log _{10} \mathrm{C}_{\mathrm{Vsat}}+\beta\left\{1-\tanh \left(\frac{\mathrm{P}-\theta}{\alpha}\right)\right\}
$$

where the aging parameter $\mathrm{P}$ is defined by

$$
\mathrm{P}=\log _{10}(\mathrm{t})-\frac{1000 \mathrm{Q}}{19.143}\left(\frac{1}{\mathrm{~T}_{\mathrm{S}}+273}-\frac{1}{673}\right)
$$

The constants $\alpha$ and $\beta$ can be determined from the initial impact energy $\mathrm{C}_{V \text { int }}$ and saturation impact energy $\mathrm{C}_{V \text { sat }}$ as follows:

$$
\alpha=-0.585+0.795 \log _{10} C_{V s a t}
$$

and

$$
\beta=\left(\log _{10} \mathrm{C}_{\text {Vint }}-\log _{10} \mathrm{C}_{\mathrm{Vsat}}\right) / 2
$$

The value of $\theta$ varies with service temperature; it is 3.3 for temperatures $<280^{\circ} \mathrm{C}\left(<536^{\circ} \mathrm{F}\right), 2.9$ for temperatures between 280 and $330^{\circ} \mathrm{C}\left(536\right.$ and $\left.626^{\circ} \mathrm{F}\right)$, and 2.5 for temperatures between 330 and $360^{\circ} \mathrm{C}\left(626\right.$ and $\left.680^{\circ} \mathrm{F}\right)$. Activation energy for thermal embrittlement is expressed in terms of both chemical composition and the constant $\theta$. The activation energy $Q$ is given by

$$
\begin{aligned}
Q= & 10\left[74.52-7.20 \theta-3.46 \mathrm{Si}-1.78 \mathrm{Cr}-4.35 \mathrm{I}_{1} \mathrm{Mn}\right. \\
& \left.+\left(148-125 \mathrm{I}_{1}\right) \mathrm{N}-61 \mathrm{I}_{2} \mathrm{C}\right],
\end{aligned}
$$

where the indicators $I_{1}=0$ and $I_{2}=1$ for CF-3 or CF-8 steels and assume the values of 1 and 0 , respectively, for CF-8M steels. Equation 20 is applicable to compositions within ASTM Specification A 351, with an upper limit of $1.2 \mathrm{wt} \%$ for Mn content. Actual Mn content is used when materials contain up to $1.2 \mathrm{wt} . \% \mathrm{Mn}$; for steels that contain $>1.2 \mathrm{wt} \% \mathrm{Mn}, 1.2$ wt.\% is assumed. Furthermore, the values of $Q$ predicted from Eq. 20 should be between $65 \mathrm{~kJ} / \mathrm{mole}(15.5 \mathrm{kcal} / \mathrm{mole})$ minimum and $250 \mathrm{~kJ} / \mathrm{mole}(59.8 \mathrm{kcal} / \mathrm{mole})$ maximum; $\mathrm{Q}$ is assumed to be $65 \mathrm{~kJ} / \mathrm{mole}$ if the predicted values are lower, and $250 \mathrm{~kJ} / \mathrm{mole}$ if the predicted values are higher.

Room-temperature impact energies of the various service-aged materials from the Shippingport reactor were estimated from Eqs. 4-20. The initial impact energy of the unaged 
Table 3. Measured and estimated Charpy-impact properties of cast stainless steel materials from the Shippingport, KRB, and Ringhals reactors

\begin{tabular}{|c|c|c|c|c|c|c|c|c|c|c|c|c|c|c|c|c|c|}
\hline \multirow[b]{2}{*}{$\begin{array}{c}\text { Material } \\
\text { ID }\end{array}$} & \multirow{2}{*}{\multicolumn{2}{|c|}{$\begin{array}{c}\text { Initial Impact } \\
\text { Energy } \\
\text { CVint }^{\mathrm{a}} \\
\left(\mathrm{J} / \mathrm{cm}^{2}\right. \\
[\mathrm{ft} \cdot \mathrm{lb}])\end{array}$}} & \multicolumn{3}{|c|}{$\begin{array}{c}\text { Saturation Impact } \\
\text { Energy CVsat } \\
\left(\mathrm{J} / \mathrm{cm}^{2} \quad[\mathrm{ft} \cdot \mid \mathrm{lb}]\right) \\
\end{array}$} & \multicolumn{5}{|c|}{$\begin{array}{c}\text { Activation Energy } \\
(\mathrm{kJ} / \mathrm{mole}[\mathrm{kcal} / \mathrm{mole}]) \\
\text { Calculated from }\end{array}$} & \multirow[b]{2}{*}{$\beta$} & \multirow[b]{2}{*}{$\alpha$} & \multirow[b]{2}{*}{$P^{d}$} & \multicolumn{4}{|c|}{$\begin{array}{c}\text { Service Time Impact } \\
\text { Energy } \mathrm{CV}_{\mathrm{V}} \\
\left(\mathrm{J} / \mathrm{cm}^{2}[\mathrm{ft} \cdot \mathrm{lb}]\right)\end{array}$} \\
\hline & & & \multicolumn{2}{|c|}{ Meas. } & Estd. & $\begin{array}{c}\text { Meas. } \\
\theta^{\mathrm{b}}\end{array}$ & \multicolumn{2}{|c|}{$\begin{array}{c}\text { Meas. } \\
\theta\end{array}$} & \multicolumn{2}{|c|}{$\begin{array}{c}\text { Estd. } \\
\theta^{\mathrm{C}}\end{array}$} & & & & \multicolumn{2}{|c|}{ Meas. } & \multicolumn{2}{|c|}{ Estd. } \\
\hline \multicolumn{18}{|c|}{$\underline{\text { Shippingport Cold Leg }}$} \\
\hline CA4 & 188 & (111) & 64 & $(38) 59$ & (35 & 2.65 & 170 & (41) & ) 123 & (29) & 0.252 & 0.822 & 2.632 & 145 & (86) 1 & 155 & (91) \\
\hline CB7 & - & & - & 107 & $(63$ & - & - & & 167 & $(40)$ & - & 1.028 & - & 183 & $(108$ & - & \\
\hline $\mathrm{CC} 4$ & - & & - & 71 & $(42$ & - & - & & 166 & $(40)$ & - & 0.887 & - & 122 & (72) & - & \\
\hline PV & 424 & (250) & - & 106 & $(63$ & - & - & & 98 & (23) & 0.302 & 1.023 & 3.132 & 322 & $(1902$ & 237 & $(140$ \\
\hline \multicolumn{18}{|c|}{ Shippingport Hot Leg } \\
\hline MA1 & 320 & $(189)$ & 141 & $(83127$ & $(75$ & 3.40 & 164 & (39) & 200 & $(48)$ & 0.201 & 1.087 & 1.715 & 299 & $(1762$ & 292 & $(172$ \\
\hline MB2 & - & & - & 175 & $(10$ & - & - & & 250 & $(60)$ & - & 1.198 & - & - & & - & \\
\hline \multicolumn{18}{|c|}{$\underline{\text { Unaged Material }}$} \\
\hline MA9 & 357 & $(210)$ & 128 & $(7624$ & $(73$ & 2.70 & 216 & (52) & 202 & $(48)$ & 0.230 & 1.078 & - & 357 & $(210$ & - & \\
\hline VR & 237 & $(140)$ & 64 & $(38 ; 62$ & (37) & 2.40 & 207 & (50) & 171 & $(41)$ & 0.290 & 0.842 & - & 237 & $(140$ & - & \\
\hline \multicolumn{18}{|c|}{ KRB Pump Cover Plate } \\
\hline $\mathrm{KRB}$ & 232 & $(137)$ & 23 & $(14) 24$ & (14) & 2.44 & 156 & (37) & 123 & (29) & 0.488 & 0.519 & 2.849 & 131 & (77) & 84 & $(50)$ \\
\hline \multicolumn{18}{|c|}{ Ringhals Elbows } \\
\hline Hot-Leg & 262 & $(155)$ & - & 56 & (33) & - & - & & 121 & (29) & 0.334 & 0.807 & 3.714 & 45 & $(27)$ & 67 & $(40)$ \\
\hline Xover-Leg & 253 & $(149)$ & - & 65 & (38) & - & - & & 122 & (29) & 0.295 & 0.857 & 3.072 & 107 & (63) 1 & 112 & $(66)$ \\
\hline
\end{tabular}

a Obtained from recovery-annealed material.

b Experimental values determined from material that was aged further at $400^{\circ} \mathrm{C}$.

c The value of $\theta$ in Eq. 20 is 3.3 for $<280^{\circ} \mathrm{C}, 2.9$ for $280-330^{\circ} \mathrm{C}$, and 2.5 for $330-360^{\circ} \mathrm{C}$.

d Values correspond to activation energies obtained with estimated values of $\theta$ and the following service conditions: Shippingport Cold-Leg Components: $113,900 \mathrm{~h}$ at $264^{\circ} \mathrm{C}$.; Hot-Leg Components: $113,900 \mathrm{~h}$ at $281^{\circ} \mathrm{C}$. KRB Pump Cover Plate: $68,000 \mathrm{~h}$ at $284^{\circ} \mathrm{C}$.

Ringhals Hot-Leg Elbow: $78,650 \mathrm{~h}$ at $325^{\circ} \mathrm{C}\left(70,000 \mathrm{~h}\right.$ at $325^{\circ} \mathrm{C}$ and $22,000 \mathrm{~h}$ at $\left.303^{\circ} \mathrm{C}\right)$.

Ringhals Crossover-Leg Elbow: $79,760 \mathrm{~h}$ at $291^{\circ} \mathrm{C}\left(70,000 \mathrm{~h}\right.$ at $291^{\circ} \mathrm{C}$ and $22,000 \mathrm{~h}$ at $\left.274^{\circ} \mathrm{C}\right)$.

materials was determined from the data for recovery-annealed material. Some materials were aged further in the laboratory at 320,350 , and $400^{\circ} \mathrm{C}\left(608,662\right.$, and $\left.752^{\circ} \mathrm{F}\right)$ to validate the estimates of the saturation impact energy $\mathrm{C}_{V \text { sat }}$ and kinetics of thermal embrittlement for the materials. The results are summarized in Table 3. The change in estimated Charpy-impact energy with aging time at temperatures between reactor service temperature and $400^{\circ} \mathrm{C}$ is shown in Figs. 22-24. The high-temperature aging data for CA4 and MA1 materials represent service-aged material that was aged further in the laboratory; aging times were adjusted to include the effect of aging at reactor temperature. For example, service of $\approx 13 \mathrm{y}$ at a cold-leg temperature of $264^{\circ} \mathrm{C}$ corresponds to $234 \mathrm{~h}$ at $400^{\circ} \mathrm{C}$ for the $\mathrm{CA} 4$ material, and service of $\approx 13 \mathrm{y}$ at a hot-leg temperature of $281^{\circ} \mathrm{C}$ corresponds to $113 \mathrm{~h}$ at $400^{\circ} \mathrm{C}$ for MA1 material.

The changes in impact energy that were estimated from activation energies obtained with experimental values of $\theta$ show very good agreement with the experimental data at all temperatures; those estimated from activation energies with assumed values of $\theta$ show good agreement at temperatures $\leq 360^{\circ} \mathrm{C}$.

The impact energy for the main valve MA1 was estimated from the compositions of MA1 and MA9 materials; the differences in the compositions of the two materials are minor. 

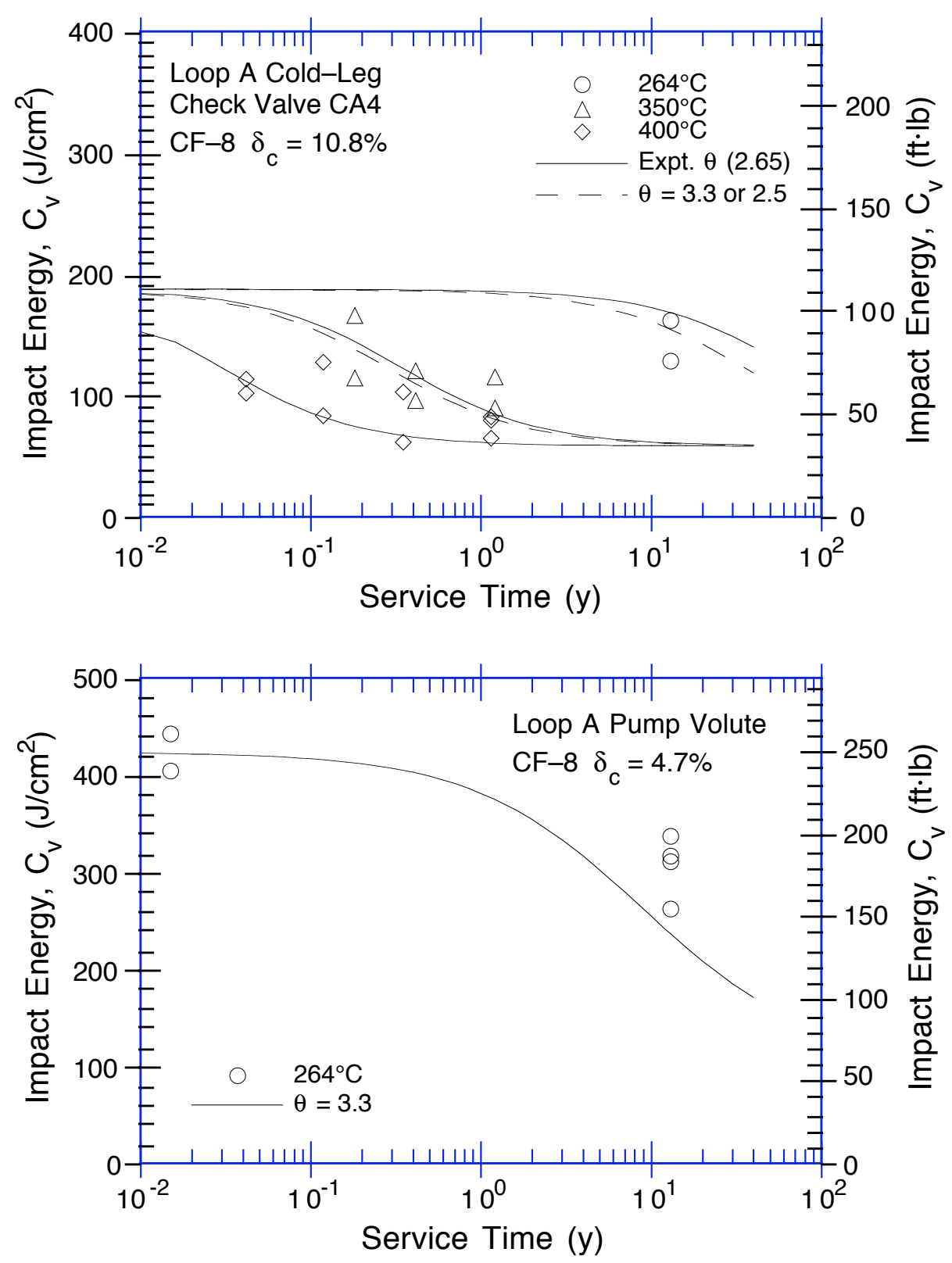

Figure 22. Variations of estimated room-temperature Charpy-impact energy with service time for Loop A cold-leg check valve CA4 and pump volute PV

Figures 23 and 24 show that, although the aging behavior at $400^{\circ} \mathrm{C}$ and the kinetics of embrittlement for MA1 and MA9 are significantly different, the estimates based on MA1 and MA9 agree well with the observed values for $\approx 13 \mathrm{y}$ of service at $281^{\circ} \mathrm{C}$. The aging behavior estimated from MA9 is slightly slower than that estimated from MA1.

The predicted minimum saturation RT impact energies also are in excellent agreement with the experimental data. The measured impact energies for the CA4, VR, MA1, and MA9 materials aged at $400^{\circ} \mathrm{C}$ achieve saturation at the predicted values. 

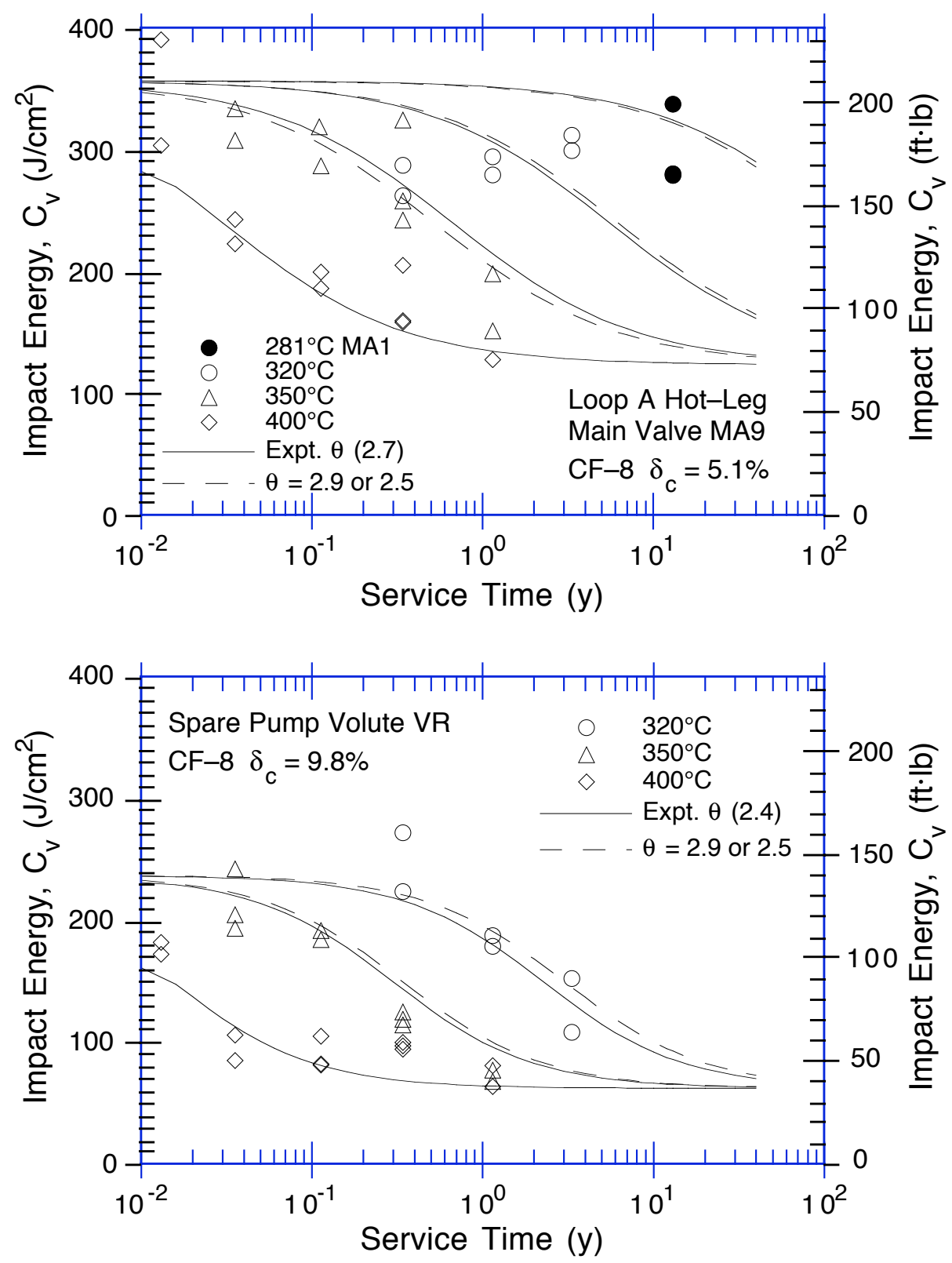

Figure 23. Variations of estimated room-temperature Charpy-impact energy with time for materials from cooler region of the hot-leg main valve MA9 and spare pump volute VR

\subsection{Fracture Toughness}

The fracture toughness J-R curve for a specific cast SS can be estimated from its RT Charpy-impact energy, $C_{V}$. The $\mathrm{J}-\mathrm{R}$ curve is expressed by the power-law relation $\mathrm{J}_{\mathrm{d}}=\mathrm{C} \Delta \mathrm{a}^{\text {n }}$ per ASTM Specifications E 813-85 and E 1152-87. At room temperature, the fracture toughness $\mathrm{J}-\mathrm{R}$ curve for static-cast $\mathrm{CF}-8$ steel is given by

$$
J_{d}=49\left[C_{V}\right]^{0.52}[\Delta a]^{n}
$$




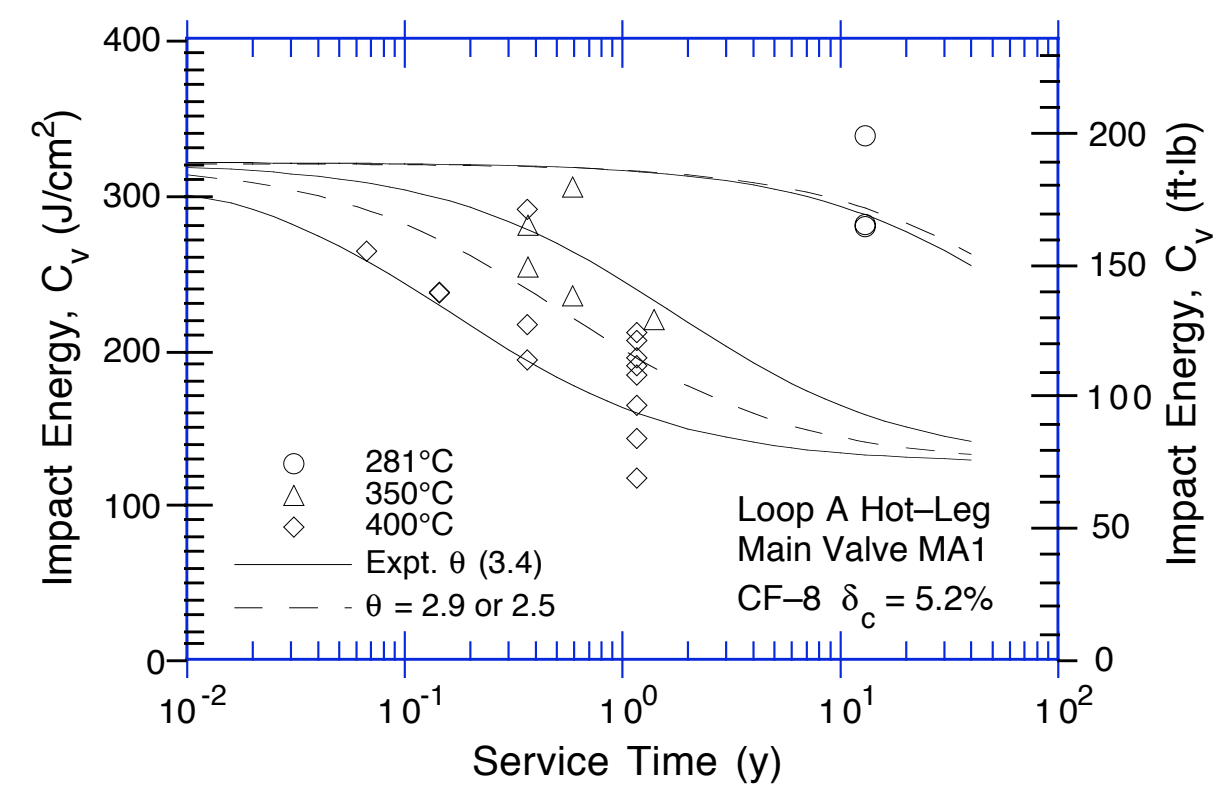

Figure 24. Variation of estimated room-temperature Charpy-impact energy with service time for Loop A hot-leg main valve MA1

where the exponent $\mathrm{n}$ is expressed as

$$
\mathrm{n}=0.20+0.12 \log _{10}\left[\mathrm{C}_{\mathrm{V}}\right]
$$

and for static-cast CF-8M steel, by

$$
J_{d}=16\left[C_{V}\right]^{0.67}[\Delta \mathrm{a}]^{\mathrm{n}},
$$

where the exponent $\mathrm{n}$ is expressed as

$$
n=0.23+0.08 \log _{10}\left[C_{V}\right] \text {. }
$$

At $290^{\circ} \mathrm{C}\left(554^{\circ} \mathrm{F}\right)$, the fracture toughness $\mathrm{J}-\mathrm{R}$ curve for static-cast $\mathrm{CF}-8$ steels is given by

$$
J_{d}=102\left[C_{V}\right]^{0.28}[\Delta a]^{n},
$$

where the exponent $\mathrm{n}$ is expressed as

$$
\mathrm{n}=0.21+0.09 \log _{10}\left[\mathrm{C}_{\mathrm{V}}\right]
$$

and for static-cast CF-8M steel, by

$$
J_{d}=49\left[C_{v}\right]^{0.41}[\Delta a]^{n},
$$

where the exponent $n$ is expressed as

$$
\mathrm{n}=0.23+0.06 \log _{10}\left[\mathrm{C}_{\mathrm{V}}\right] \text {. }
$$


The $\mathrm{J}-\mathrm{R}$ curve at any intermediate temperature can be linearly interpolated from the estimated values of $\mathrm{C}$ and $\mathrm{n}$ at room temperature and at $290^{\circ} \mathrm{C}$.

The fracture toughness J-R curves for the CA4, MA1, and PV materials after reactor service were estimated from Eqs. 7-28 and RT Charpy-impact energies for the materials were determined by the procedure described in Section 4.1. For all materials, the saturation fracture toughness $J-R$ curve, i.e., the minimum J-R curve that would be achieved for the specific composition after long-term aging, was estimated from Eqs. 7-28 and saturation RT impact energy, $\mathrm{C}_{V \text { sat. }}$. However, the initial fracture toughness $\mathrm{J}-\mathrm{R}$ curve was used as an upper bound for the material. The correlations described in Eqs. 7-28 account for the degradation of mechanical properties of typical heats of cast SS. They do not consider the initial fracture properties of the unaged material. Some heats of cast SSs may exhibit a low initial fracture toughness, and the estimated $\mathrm{J}-\mathrm{R}$ curve may be higher than the initial curve. When the estimated $\mathrm{J}-\mathrm{R}$ curve is higher than the initial fracture toughness $\mathrm{J}-\mathrm{R}$ curve, the latter is used as the $J-R$ curve of the material. The failure mechanism of materials with low initial fracture toughness is controlled by processes other than those that cause thermal embrittlement of cast SSs; such materials will undergo little or no change in fracture toughness because of thermal aging during service.

The CMTR for a specific cast SS component provides information on chemical composition, tensile strength, and possibly Charpy-impact energy of the material; fracture toughness is not available in CMTRs. The fracture toughness $\mathrm{J}-\mathrm{R}$ curve for unaged material was obtained by using the initial RT Charpy-impact energy, $\mathrm{C}_{V \text { int }}$, instead of $\mathrm{C}_{V}$ in Eqs. 21-28. The estimated and experimental fracture toughness $\mathrm{J}-\mathrm{R}$ curves at room temperature and at $290^{\circ} \mathrm{C}$ for the CA4, MA1, PV, and VR materials in the unaged or recovery-annealed condition, after service, and at saturation, are shown in Figs. 25-28.

The estimated J-R curves either show good agreement, e.g., CA4 and VR materials, or are slightly lower (30-50\%) than the experimental results, e.g., MA1 and PV materials. The somewhat conservative estimates are expected for some compositions of cast SSs; the criteria used in developing the estimation scheme ensure that the estimated mechanical properties are adequately conservative for cast SSs as defined by ASTM Specification A-351.5-8 They do not consider the effects of metallurgical differences that may arise from differences in production heat treatment or casting processes and, therefore, may be overly conservative for some steels. The estimates are consistent with the experimental data. For example, the estimation scheme predicts relatively modest decreases in fracture toughness for the materials after reactor service. Also, the correlations predicted that the spare pump volute VR would exhibit the observed saturation fracture toughness, which was lower than that for the other materials.

\subsection{Tensile Properties}

Thermal aging of cast SSs increases their tensile strength, particularly their ultimate stress. The increase in yield or flow stress of aged cast SSs is estimated from a correlation between the ratio of tensile yield or flow stress of aged, and unaged material and the aging parameter, P.6,8 At room temperature, the tensile-flow-stress ratio $R_{f}=\left(\sigma_{f}\right.$ aged $\left./ \sigma_{f_{\text {unaged }}}\right)$ for CF-8 steel is given by

$$
R_{f}=0.84+0.08 P
$$


Crack Extension $\Delta$ a (in.)
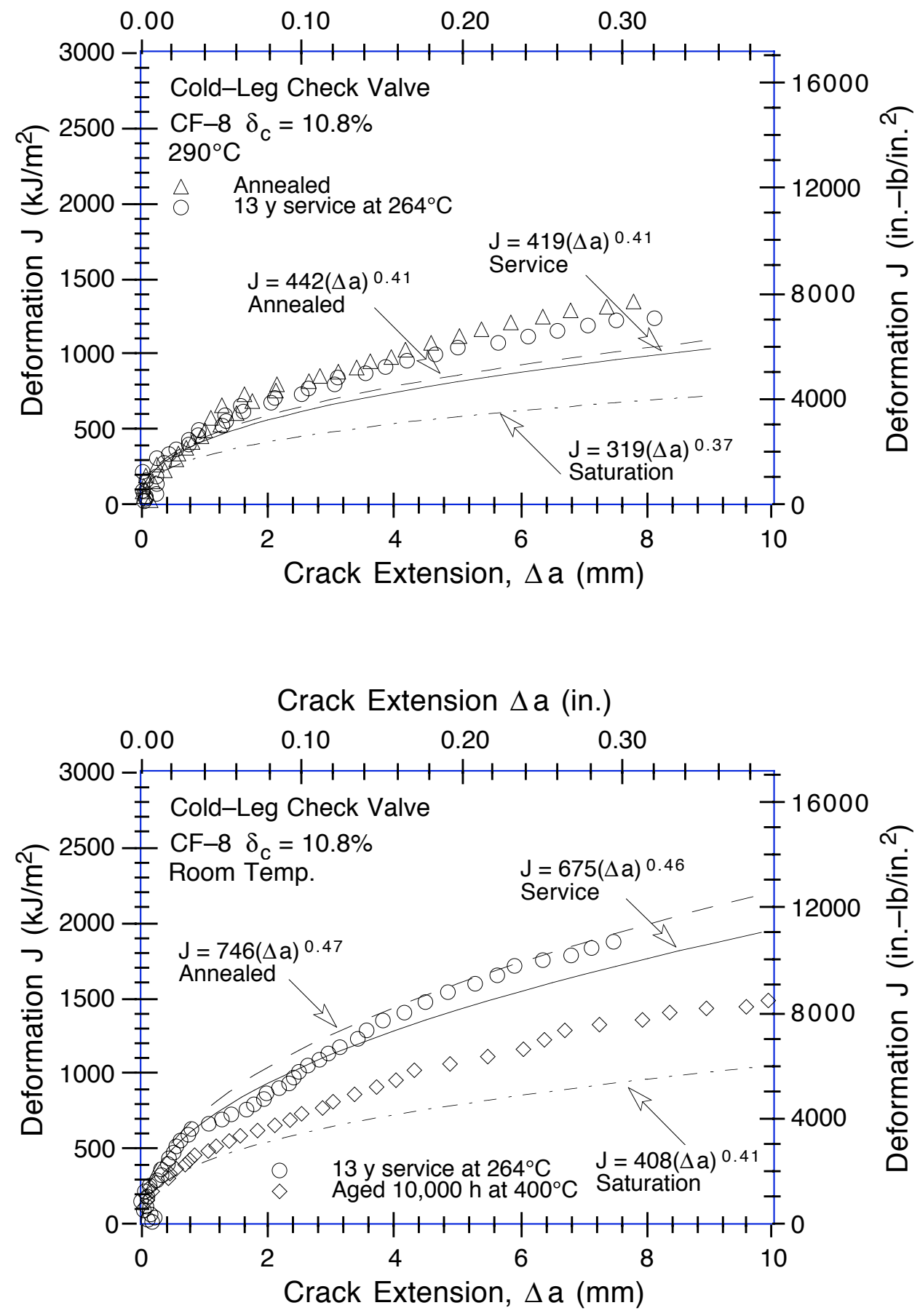

Figure 25. Estimated and measured fracture toughness $J-R$ curves for the cold-leg check valve in the annealed, 13-y service at $264^{\circ} \mathrm{C}$, and fully embrittled or saturation condition. (Dashed, solid, and chain-dot lines are the best-fit power-law $J-R$ curves for annealed, service-aged, and laboratory-aged materials, respectively.) 
Crack Extension $\Delta$ a (in.)
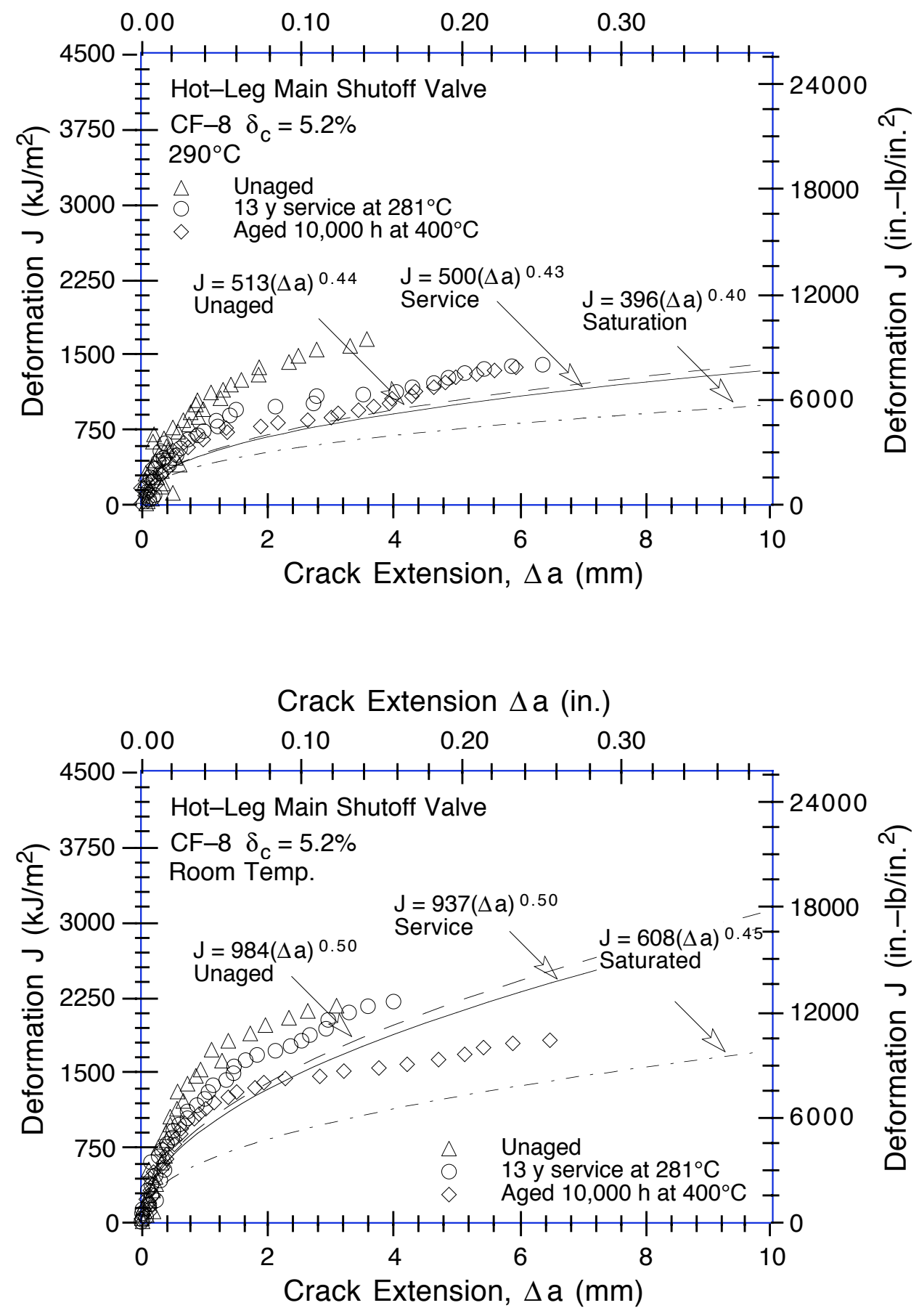

Figure 26. Estimated and measured fracture toughness $J-R$ curves for the hot-leg main shutoff valve in essentially unaged, 13-y service at $281^{\circ} \mathrm{C}$, and fully embrittled or saturation condition. (Dashed, solid, and chain-dot lines are the best-fit power-law $\mathrm{J}-R$ curves for unaged, service-aged, and laboratory-aged materials, respectively.) 

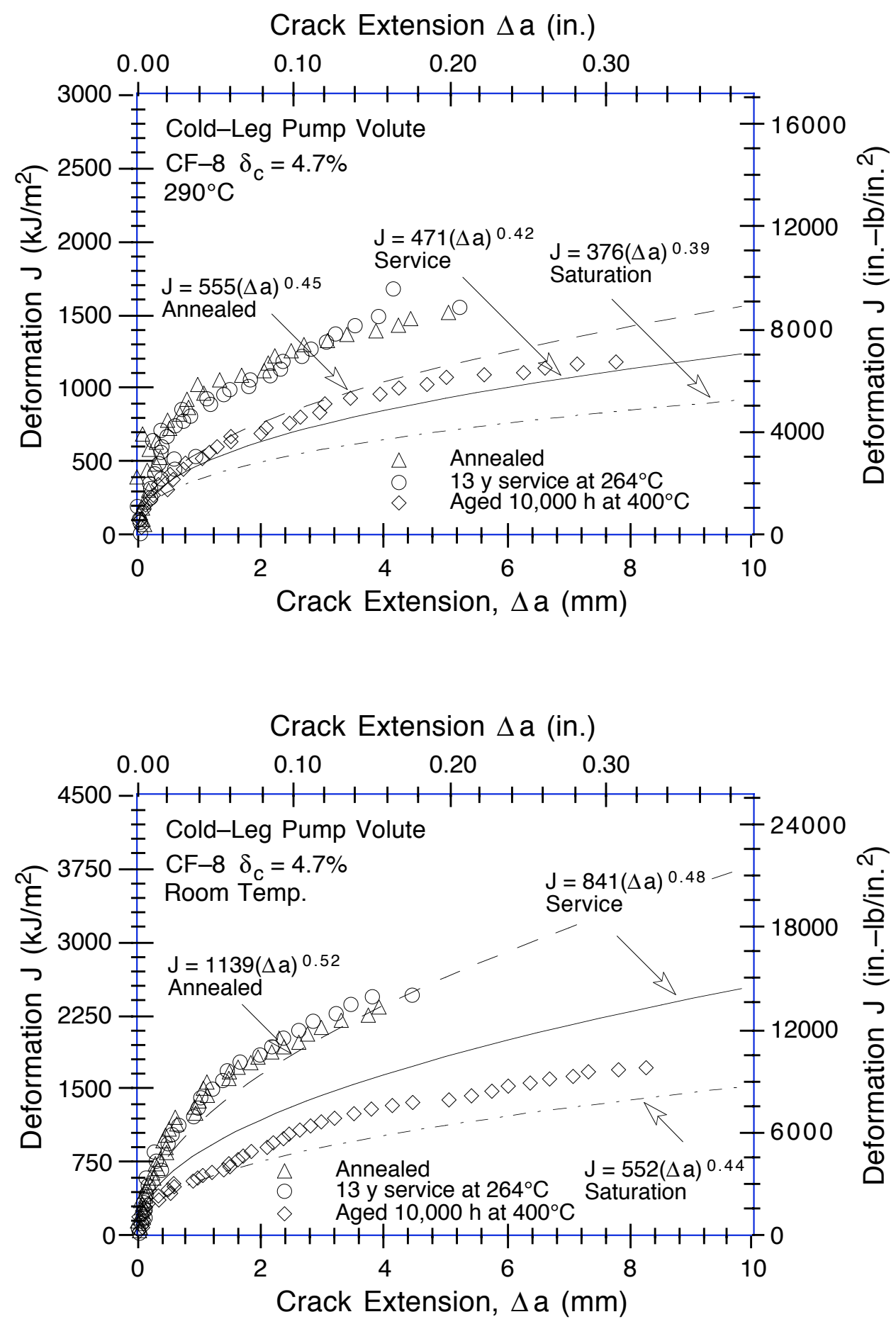

Figure 27. Estimated and measured fracture toughness $J-R$ curves for the cold-leg pump volute in the annealed, 13-y service at $264^{\circ} \mathrm{C}$, and fully embrittled or saturation condition. (Dashed, solid, and chain-dot lines are the best-fit power-law $J-R$ curves for annealed, service-aged, and laboratory-aged materials, respectively.) 
Crack Extension $\Delta$ a (in.)
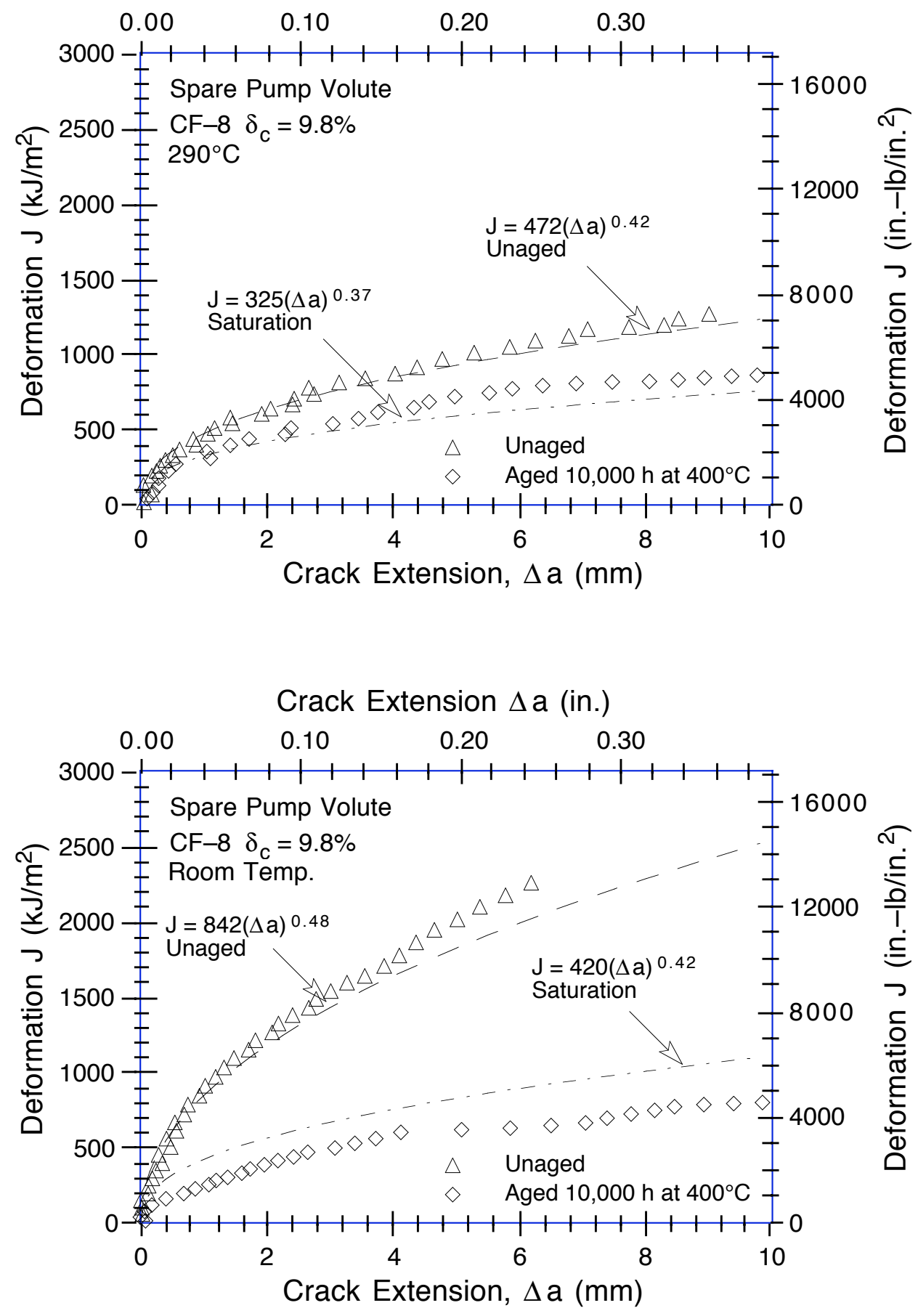

Figure 28. Estimated and measured fracture toughness $J-R$ curves for the spare pump volute in the unaged and fully embrittled or saturation condition. (Dashed and chain-dot lines are the best-fit power-law $\mathcal{J}-R$ curves for unaged and laboratory-aged materials, respectively.) 
and for CF-8M steel, by

$$
R_{f}=0.77+0.10 P \quad\left(1.00 \leq R_{f} \leq 1.19\right) .
$$

At $290^{\circ} \mathrm{C}\left(554^{\circ} \mathrm{F}\right)$, the tensile-flow-stress ratio for $\mathrm{CF}-8$ steel is given by

$$
R_{f}=0.83+0.09 P \quad\left(1.00 \leq R_{f} \leq 1.14\right)
$$

and for CF-8M steel, by

$$
R_{f}=0.69+0.14 P \quad\left(1.00 \leq R_{f} \leq 1.24\right) .
$$

The data on tensile properties of cast stainless steels indicate that the increase in yield stress due to thermal aging is much lower than the increase in ultimate stress. At room temperature, the tensile-yield-stress ratio $R_{y}=\left(\sigma_{\text {yaged }} / \sigma_{y}\right.$ unaged $)$ for CF- 8 steel is given by

$$
R_{y}=0.798+0.076 P \quad\left(1.00 \leq R_{y} \leq 1.10\right)
$$

and for CF-8M steel, by

$$
R_{y}=0.708+0.092 P \quad\left(1.00 \leq R_{y} \leq 1.10\right) .
$$

At $290^{\circ} \mathrm{C}\left(554^{\circ} \mathrm{F}\right)$, the tensile-yield-stress ratio for CF-8 steel is given by

$$
R_{y}=0.788+0.086 P \quad\left(1.00 \leq R_{y} \leq 1.09\right)
$$

and for CF-8M steel, by

$$
R_{y}=0.635+0.129 P \quad\left(1.00 \leq R_{y} \leq 1.14\right) \text {. }
$$

The minimum and maximum values of the ratio $R_{f}$ are given for each grade of steel and temperature, i.e., a minimum or maximum value is assumed, respectively, when the calculated ratio is smaller than the minimum or greater than the maximum. Equations 29-36 are valid for service temperatures between 280 and $330^{\circ} \mathrm{C}\left(536\right.$ and $\left.626^{\circ} \mathrm{F}\right)$ and ferrite content $>7 \%$ for CF-8M steel and $>10 \%$ for CF-3 and CF-8 steels. Thermal aging has little or no effect on the tensile strength of cast SSs with low ferrite content.

Experimental and estimated tensile yield and flow stress at $290^{\circ} \mathrm{C}\left(554^{\circ} \mathrm{F}\right)$ and at room temperature for the various Shippingport materials are given in Table 4. The materials from the hot-leg main shutoff valve and cold-leg pump volute contain $<10 \%$ ferrite and, therefore, would show little or no increase in tensile strength. As borne out by experimental data, the tensile strength of these materials remains unchanged after service. Although Eqs. 29-36 are recommended for service temperatures between 280 and $330^{\circ} \mathrm{C}$, the increase in tensile yield and flow stress for the cold-leg check valve after service at $264^{\circ} \mathrm{C}$ and the spare pump volute that was aged at $400^{\circ} \mathrm{C}$ in the laboratory was obtained from these correlations and Eqs. 17 and 20. A $\theta$ value of 3.3 was used for the check valve. The estimated values presented in Table 4 show good agreement with the measured values.

Fracture toughness $J_{I C}$ values for service-aged materials were determined from the estimated $\mathrm{J}-\mathrm{R}$ curve and flow stress, and are also given in Table 4. The estimated values of $J_{I C}$ 
Table 4. Measured and estimated tensile yield and flow stresses and J/C values for serviceand laboratory-aged cast stainless steelsa

\begin{tabular}{|c|c|c|c|c|c|c|c|c|c|}
\hline \multirow{2}{*}{$\begin{array}{l}\text { Material } \\
\text { ID }\end{array}$} & \multirow{2}{*}{$\begin{array}{c}\text { Test } \\
\text { Temp. }\left({ }^{\circ} \mathrm{C}\right)\end{array}$} & \multicolumn{3}{|c|}{ Yield Stress $(\mathrm{MPa})^{\mathrm{b}}$} & \multicolumn{3}{|c|}{ Flow Stress $(\mathrm{MPa})^{\mathrm{b}}$} & \multicolumn{2}{|c|}{$J_{I C}\left(\mathrm{~kJ} / \mathrm{m}^{2}\right)$} \\
\hline & & Unaged & Measured & Estimated & Unaged & Measured & Estimated & Measured & Estimated \\
\hline \multicolumn{10}{|c|}{ Service-Aged Material from the Shippingport Reactor } \\
\hline \multirow[t]{2}{*}{$\overline{\mathrm{CA} 4}$} & 25 & $(208)$ & $228 \quad(222)$ & 208 & ( 363 ) & $377 \quad(382)$ & 381 & 476 & 503 \\
\hline & 290 & $(125)$ & 142 (128) & 127 & $(246)$ & $262(245)$ & 263 & 361 & 316 \\
\hline \multirow[t]{2}{*}{ MA1 } & 25 & 229 & 231 & 229 & 360 & 350 & 360 & 1407 & 825 \\
\hline & 290 & 160 & 132 & 160 & 260 & 237 & 260 & 739 & 395 \\
\hline \multirow[t]{2}{*}{ PV } & 25 & $(209)$ & $230 \quad(202)$ & 209 & ( 362 ) & $370 \quad(368)$ & 362 & 1509 & 699 \\
\hline & 290 & (131) & $157 \quad(126)$ & 131 & $(269)$ & $266 \quad(237)$ & 269 & 858 & 362 \\
\hline \multicolumn{10}{|c|}{ Service-Aged Material from the KRB Reactor } \\
\hline \multirow[t]{2}{*}{ KRB } & 25 & 298 & 296 & 302 & 428 & 428 & 457 & 263,396 & 323 \\
\hline & 290 & 178 & 201 & 184 & 294 & 329 & 320 & 681 & 243 \\
\hline \multicolumn{10}{|c|}{$\begin{array}{l}\text { Service-Aged Material from the Ringhals } 2 \\
\text { Reactor }\end{array}$} \\
\hline \multirow[t]{2}{*}{$\begin{array}{l}\text { Hot- } \\
\text { Leg }\end{array}$} & 25 & 272 & 267 & 286 & 399 & 424 & 455 & 250,330 & 169 \\
\hline & 290 & 167 & 163 & 186 & 277 & 306 & 335 & - & 192 \\
\hline \multirow{3}{*}{$\begin{array}{l}\text { Xover-L } \\
\text { eg }\end{array}$} & 25 & 242 & 256 & 242 & 369 & 392 & 397 & 960,525 & 252 \\
\hline & & & & & & & & $960, \quad 600$ & \\
\hline & 290 & 184 & 148 & 190 & 290 & 277 & 325 & - & 243 \\
\hline \multicolumn{10}{|c|}{ Essentially Unaged Material from the Shippingport Reactor Aged for $10,000 \mathrm{~h}$ at $400^{\circ} \mathrm{C}$ in the Laboratory } \\
\hline \multirow[t]{2}{*}{ MA9 } & 25 & 229 & 236 & 229 & 360 & 372 & 360 & 1094 & 442 \\
\hline & 290 & 160 & 144 & 160 & 260 & 260 & 260 & 629 & 294 \\
\hline \multirow[t]{2}{*}{ VR } & 25 & 273 & 274 & 300 & 405 & 438 & 470 & 123 & 269 \\
\hline & 290 & 159 & 185 & 173 & 267 & 305 & 304 & 214 & 228 \\
\hline \multicolumn{10}{|c|}{$\begin{array}{l}\text { The service conditions for the materials are as follows: } \\
\text { Shippingport Cold-Leg Components: } 113,900 \mathrm{~h} \text { at } 264^{\circ} \mathrm{C} \text {. } \\
\text { Shippingport Hot-Leg Components: } 113,900 \mathrm{~h} \text { at } 281^{\circ} \mathrm{C} \text {. } \\
\text { KRB Pump Cover Plate: } 68,000 \mathrm{~h} \text { at } 284^{\circ} \mathrm{C} \text {. } \\
\text { Ringhals Hot-Leg Elbow: } 78,650 \mathrm{~h} \text { at } 325^{\circ} \mathrm{C}\left(70,000 \mathrm{~h} \text { at } 325^{\circ} \mathrm{C} \text { and } 22,000 \mathrm{~h} \text { at } 303^{\circ} \mathrm{C}\right) \text {. } \\
\text { Ringhals Crossover-Leg Elbow: } 79,760 \mathrm{~h} \text { at } 291^{\circ} \mathrm{C}\left(70,000 \mathrm{~h} \text { at } 291^{\circ} \mathrm{C} \text { and } 22,000 \mathrm{~h} \text { at } 274^{\circ} \mathrm{C}\right) \text {. } \\
\text { b Baseline tensile properties of unaged materials were obtained as follows: } \\
\text { Values in parantheses were determined from instrumented Charpy-impact tests. } \\
\text { Experimental values of MA9 were used for MA1. }\end{array}$} \\
\hline
\end{tabular}

show very good agreement with the measured value for CA4 and VR materials and are 30-50\% lower for MA1, MA9, and PV materials. As mentioned earlier in this section, these correlations do not consider the effect of microstuctural differences and may be conservative for some materials.

The engineering stress-vs.-strain behavior of aged cast stainless steel can also be obtained from the estimated flow stress. 6,8 The engineering stress-vs.-strain curve is expressed by the Ramberg-Osgood equation

$$
\frac{\varepsilon}{\varepsilon_{\mathrm{o}}}=\frac{\sigma}{\sigma_{\mathrm{o}}}+\alpha_{1}\left(\frac{\sigma}{\sigma_{\mathrm{o}}}\right)^{\mathrm{n}_{1}}
$$


where $\sigma$ and $\varepsilon$ are engineering stress and strain, respectively; $\sigma_{0}$ is an arbitrary reference stress, often assumed to be equal to flow or yield stress; the reference strain $\varepsilon_{0}=\sigma_{0} / E ; \alpha_{1}$ and $n_{1}$ are Ramberg-Osgood parameters; and $\mathrm{E}$ is elastic modulus. The Ramberg-Osgood equation can be rearranged to the form

$$
\frac{E \varepsilon-\sigma}{\sigma_{\mathrm{f}}}=\alpha_{1}\left(\frac{\sigma}{\sigma_{\mathrm{f}}}\right)^{\mathrm{n}_{1}} \text {. }
$$

For all grades of cast stainless steel, the parameter $n_{1}$ does not change with thermal aging. The parameter $\alpha_{1}$ decreases with aging and shows good correlation with the flow stress $\sigma_{f}$ of the material. For engineering stress-vs.-strain curves up to $5 \%$ strain, the Ramberg-Osgood parameters at room temperature, for $\mathrm{CF}-8$ steels, are given by

$$
\alpha_{1}=157.9-0.300 \sigma_{f} \quad\left(n_{1}=6.4\right)
$$

and for CF-8M steel, by

$$
\alpha_{1}=50.9-0.0724 \sigma_{f} \quad\left(n_{1}=5.6\right) .
$$

At $290^{\circ} \mathrm{C}\left(554^{\circ} \mathrm{F}\right)$, the Ramberg-Osgood parameters for engineering stress-vs.-strain curves up to $5 \%$ strain, for CF-8 steels, are given by

$$
\alpha_{1}=153.3-0.373 \sigma_{f} \quad\left(n_{1}=7.1\right) ;
$$

and for CF-8M steel, by

$$
\alpha_{1}=145.9-0.314 \sigma_{f} \quad\left(n_{1}=6.6\right) .
$$

Estimated and measured tensile stress-vs.-strain curves at room temperature and at $290^{\circ} \mathrm{C}$ for the various Shippingport materials are shown in Figs. 29-33. Values of $200 \mathrm{GPa}$ at room temperature and $180 \mathrm{GPa}$ at $290^{\circ} \mathrm{C}$ were used for elastic modulus $\mathrm{E}$ in Eq. 38. The estimated curves show excellent agreement with the experimental data.

\section{Ringhals Reactor Elbows}

Investigation of the hot- and crossover-leg elbows from the Ringhals reactor indicated significant degradation of impact strength and fracture toughness of the hot-leg elbow after $15 \mathrm{y}$ of service at $325^{\circ} \mathrm{C}$, whereas the crossover-leg elbow in service at $291^{\circ} \mathrm{C}$, showed only moderate degradation. ${ }^{17}$ The mechanical properties of the Ringhals elbows were estimated from the correlations presented in Section 4 for CF-8M steel that contained $>10 \% \mathrm{Ni}$. Information on the chemical composition and initial Charpy-impact energy and tensile strength of the unaged materials was used in the estimations; $\theta$ was assumed to be 2.9. The results for Charpy-impact and tensile properties are summarized in Tables 3 and 4, respectively.

The experimental data and estimated decrease in impact energy for hot- and crossover-leg elbows during service at 325 and $291^{\circ} \mathrm{C}$, respectively, are shown in Fig. 34 . The estimated value of $67 \mathrm{~J} / \mathrm{cm}^{2}$ for the hot-leg elbow is marginally higher than the measured average values of $45 \mathrm{~J} / \mathrm{cm}^{2}$ (equivalent Charpy $\mathrm{V}$-notch impact energy converted from U-notch value) and 

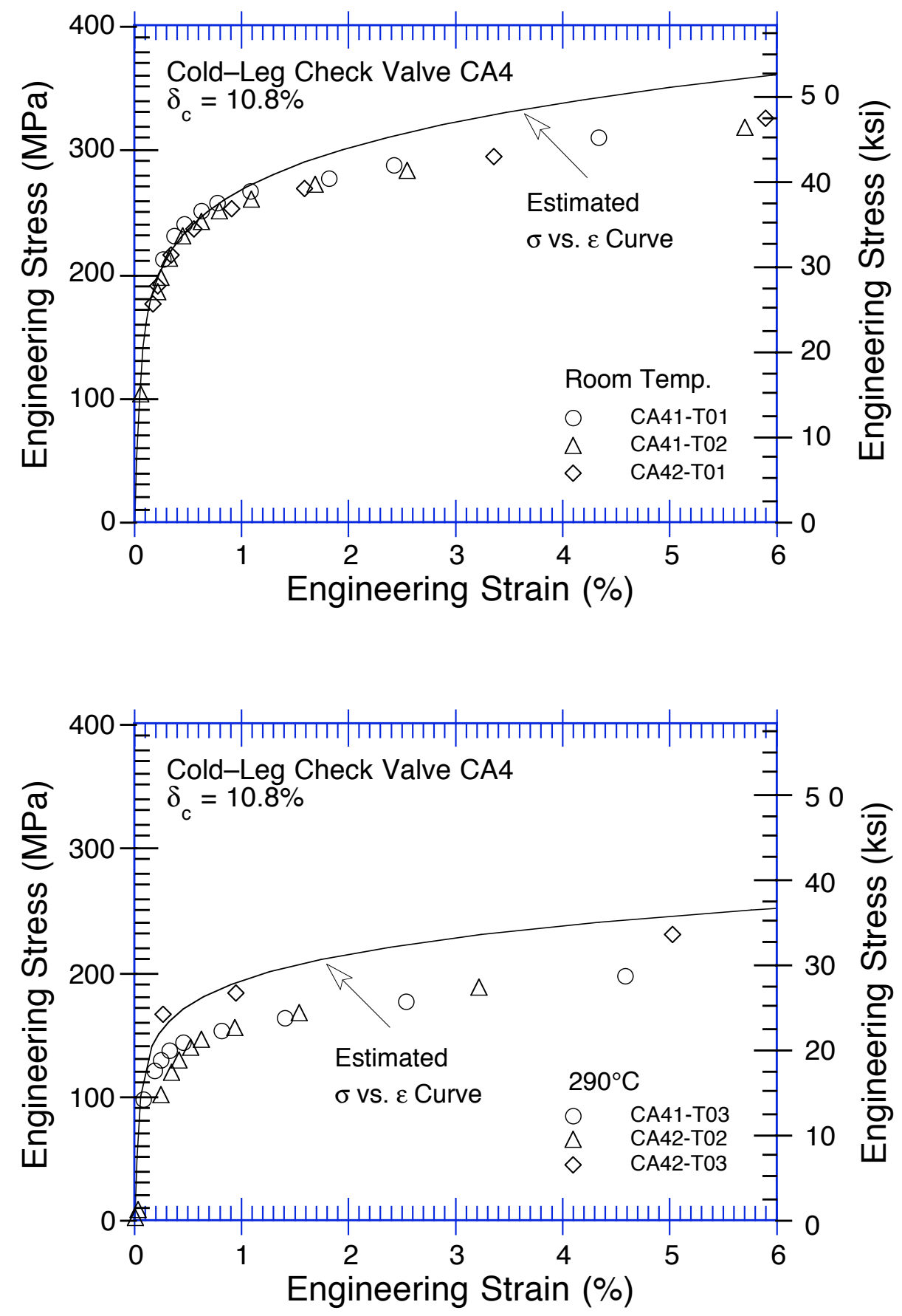

Figure 29. Estimated and measured tensile stress-vs.-strain curves at room temperature and $290^{\circ} \mathrm{C}$ for the cold-leg check valve after service for $\approx 13$ y at $264^{\circ} \mathrm{C}$ 

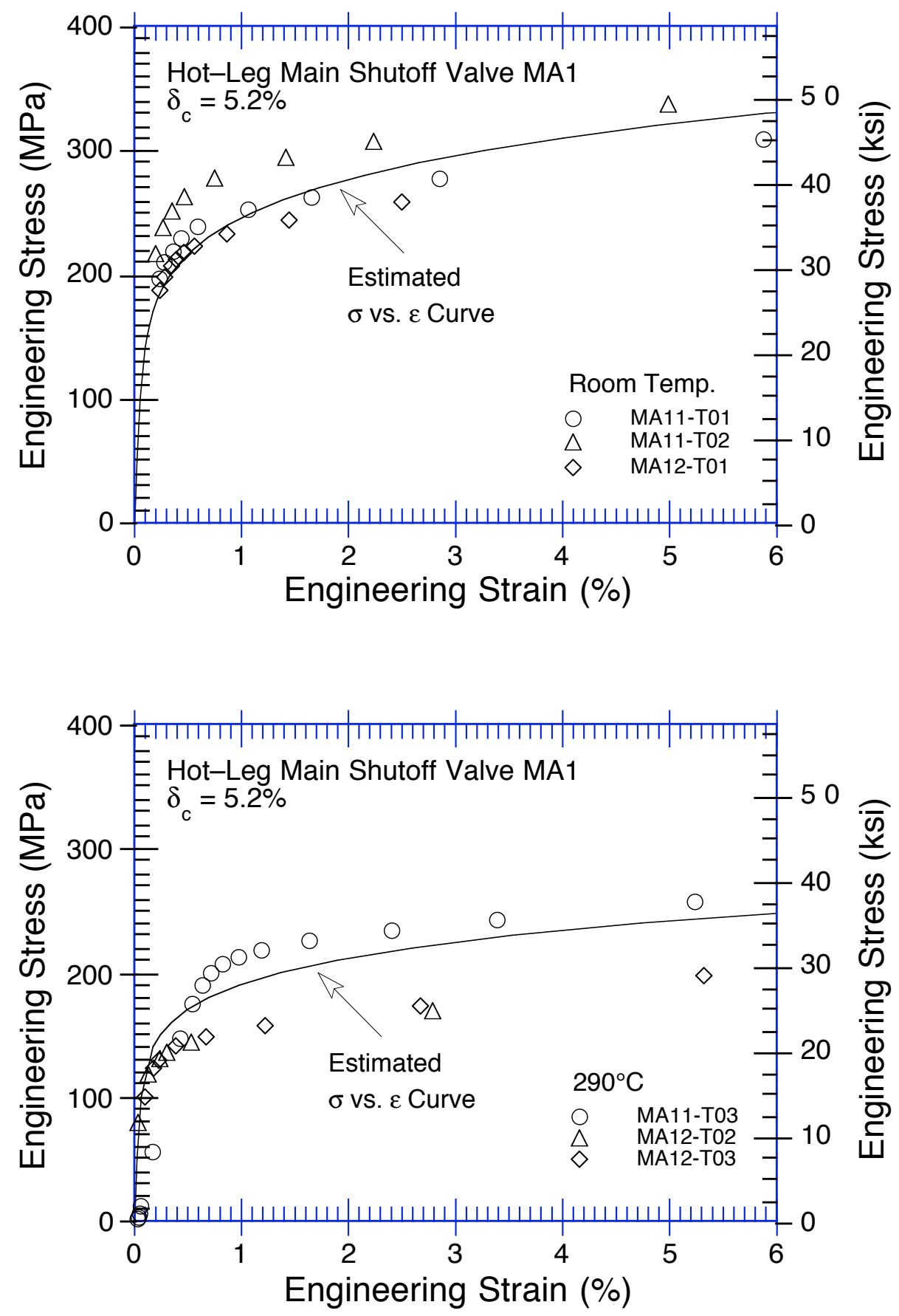

Figure 30. Estimated and measured tensile stress-vs.-strain curves at room temperature and $290^{\circ} \mathrm{C}$ for the hot-leg main shutoff valve after service for $\approx 13 \mathrm{y}$ at $281^{\circ} \mathrm{C}$ 

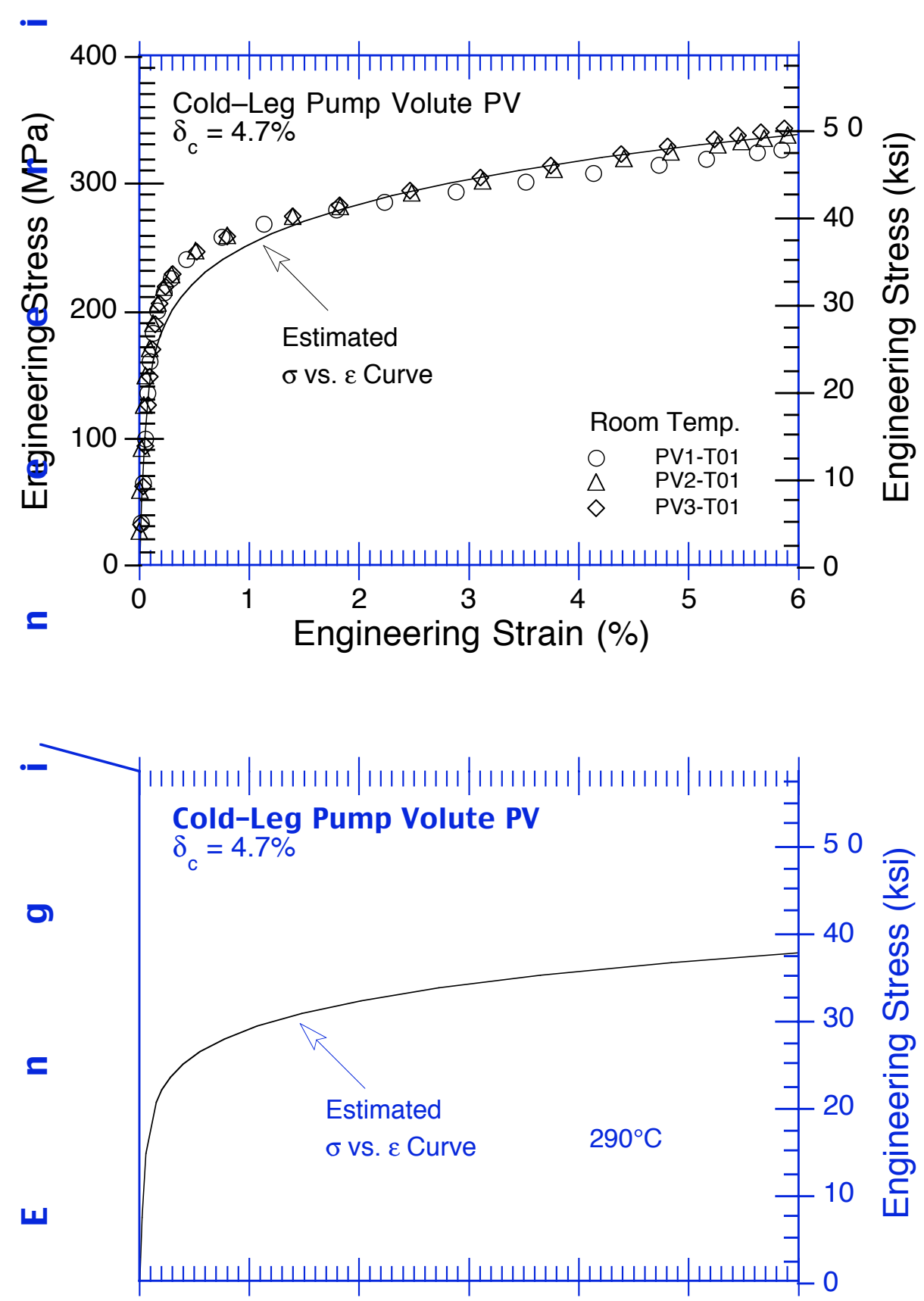

Engineering Strain (\%)

Figure 31. Estimated and measured tensile stress-vs.-strain curves at room temperature and $290^{\circ} \mathrm{C}$ for the cold-leg pump volute after service for $\approx 13$ y at $264^{\circ} \mathrm{C}$ 

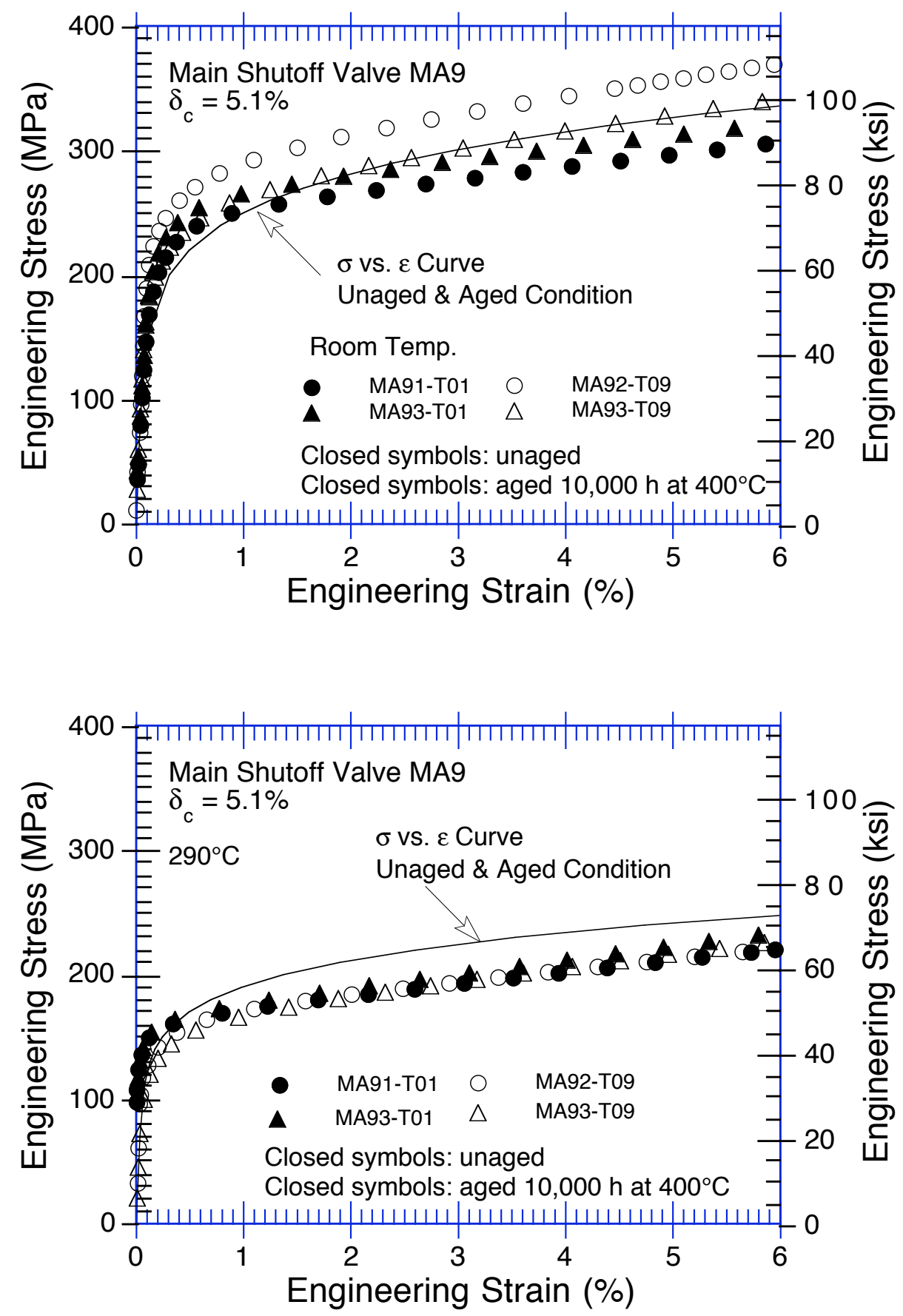

Figure 32. Estimated and measured tensile stress-vs.-strain curves at room temperature and $290^{\circ} \mathrm{C}$ for material from cooler regions of the hot-leg main shutoff valve in the unaged and fully embrittled or aged condition 

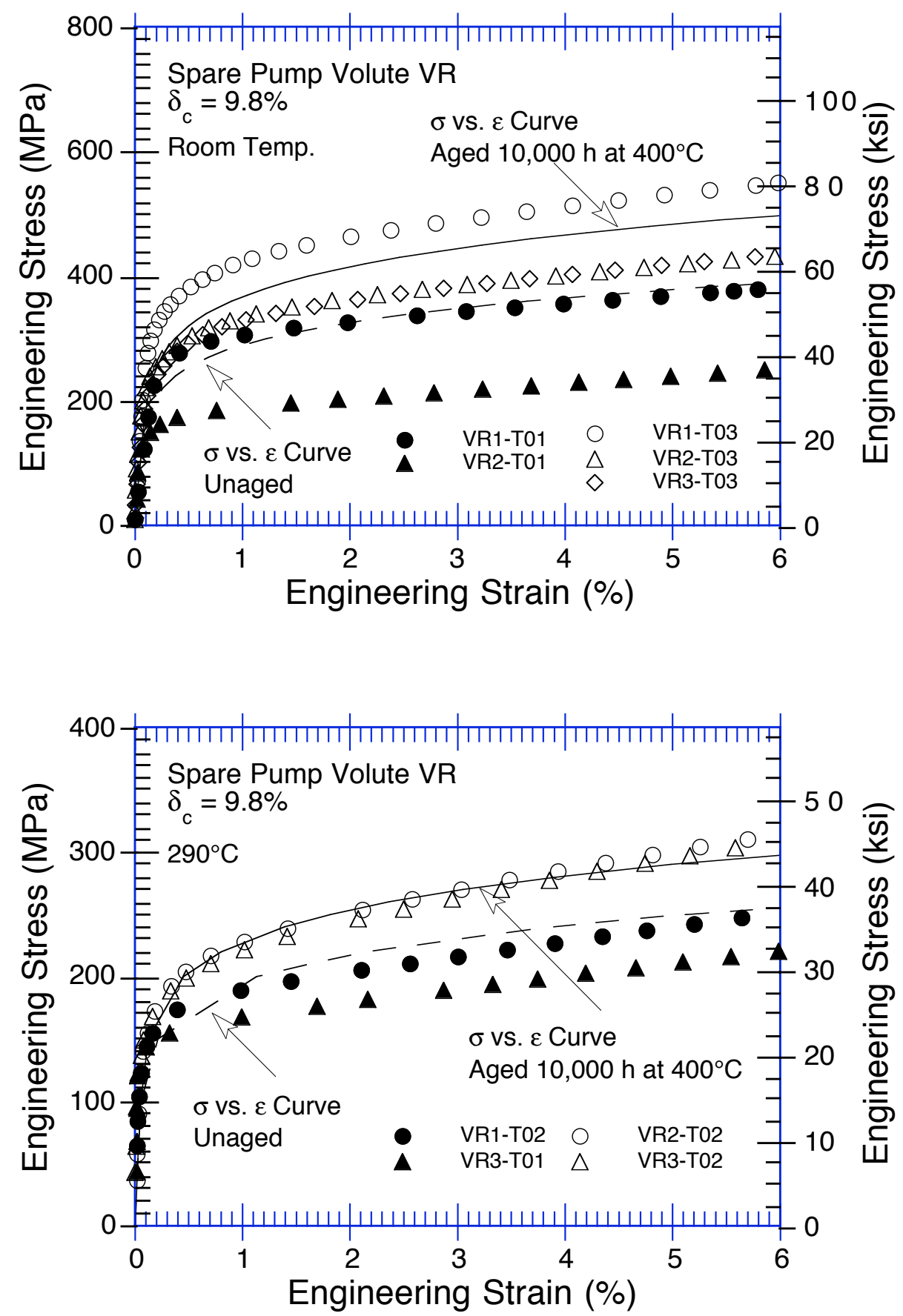

Figure 33. Estimated and measured tensile stress-vs.-strain curves at room temperature and $290^{\circ} \mathrm{C}$ for the spare pump volute in the unaged and fully embrittled or aged condition 


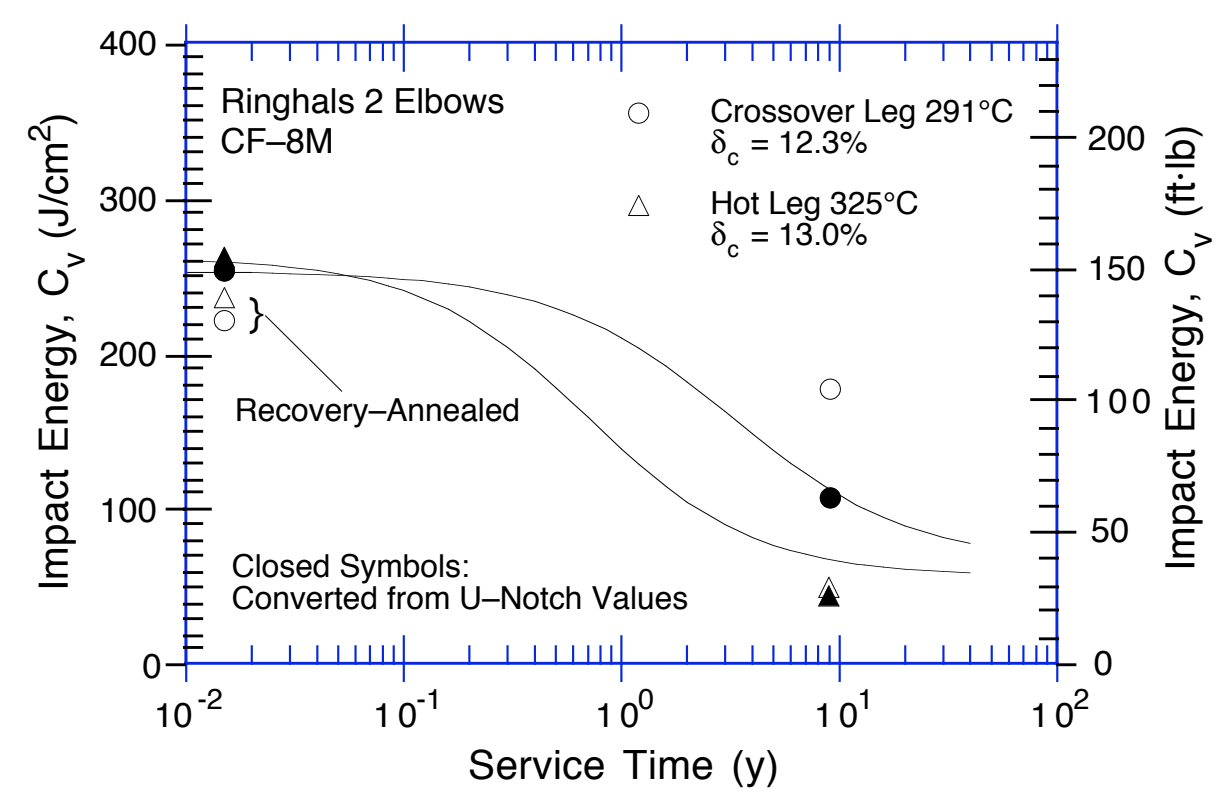

Figure 34. Estimated and experimentally observed room-temperature Charpy-impact energy for the Ringhals hot-and crossover-leg elbows. (Solid lines represent estimated decrease in impact energy.)

$50 \mathrm{~J} / \mathrm{cm}^{2}$ (from Charpy $\mathrm{V}$-notch specimens). The estimated $112 \mathrm{~J} / \mathrm{cm}^{2} \mathrm{impact}$ energy for the crossover-leg agrees well with the $107 \mathrm{~J} / \mathrm{cm}^{2}$ measured from $\mathrm{U}$-notch specimens and is significantly lower than the $177 \mathrm{~J} / \mathrm{cm}^{2}$ obtained from $\mathrm{V}$-notch specimens. The difference between the $\mathrm{V}$ - and $\mathrm{U}$-notch impact energy for the crossover-leg elbow is most likely due to a significant variation in the ferrite content of the material. The saturation impact energies for hot- and crossover-leg elbows are estimated to be 56 and $67 \mathrm{~J} / \mathrm{cm}^{2}$, respectively.

Fracture toughness $\mathrm{J}-\mathrm{R}$ curves can be estimated from the impact energy. Room-temperature $\mathrm{J}-\mathrm{R}$ curves for hot- and crossover-leg elbows after $\approx 15 \mathrm{y}$ of service are shown in Fig. 35 . Only the experimental $J_{I C}$ values (not the complete $J-R$ curve) have been reported for these materials. 17 The tensile yield and flow stresses and $J_{I C}$ at room temperature and $290^{\circ} \mathrm{C}$ for the Ringhals elbows were also estimated by the procedure described in Section 4.3; the results are given in Table 4. The estimated tensile properties are in good agreement with the measured values. The $J_{I C}$ for the hot-leg elbow also is comparable to the measured value, whereas that for the crossover-leg elbow is $\mathbf{5 0 - 7 0 \% ~ l o w e r . ~ A s ~ m e n t i o n e d ~ a b o v e , ~ t h e ~ f e r r i t e ~ c o n t e n t ~ o f ~ t h e ~}$ crossover-leg elbow varies significantly. Furthermore, the correlations do not consider the effect of microstuctural differences and may be conservative for some materials.

\section{KRB Reactor Pump Cover Plate}

The mechanical properties of the pump cover plate assembly from the KRB reactor were also estimated from the correlations presented in Section 4. The material was in service at $284^{\circ} \mathrm{C}$ for $\approx 8 \mathrm{y}$. The results for Charpy-impact and tensile properties are summarized in Tables 3 and 4, respectively. The variation of experimental and estimated RT Charpy-impact energy with service time or after aging at 320,350 , and $400^{\circ} \mathrm{C}$ in the laboratory, is shown in Fig. 36. 
Crack Extension $\Delta$ a (in.)
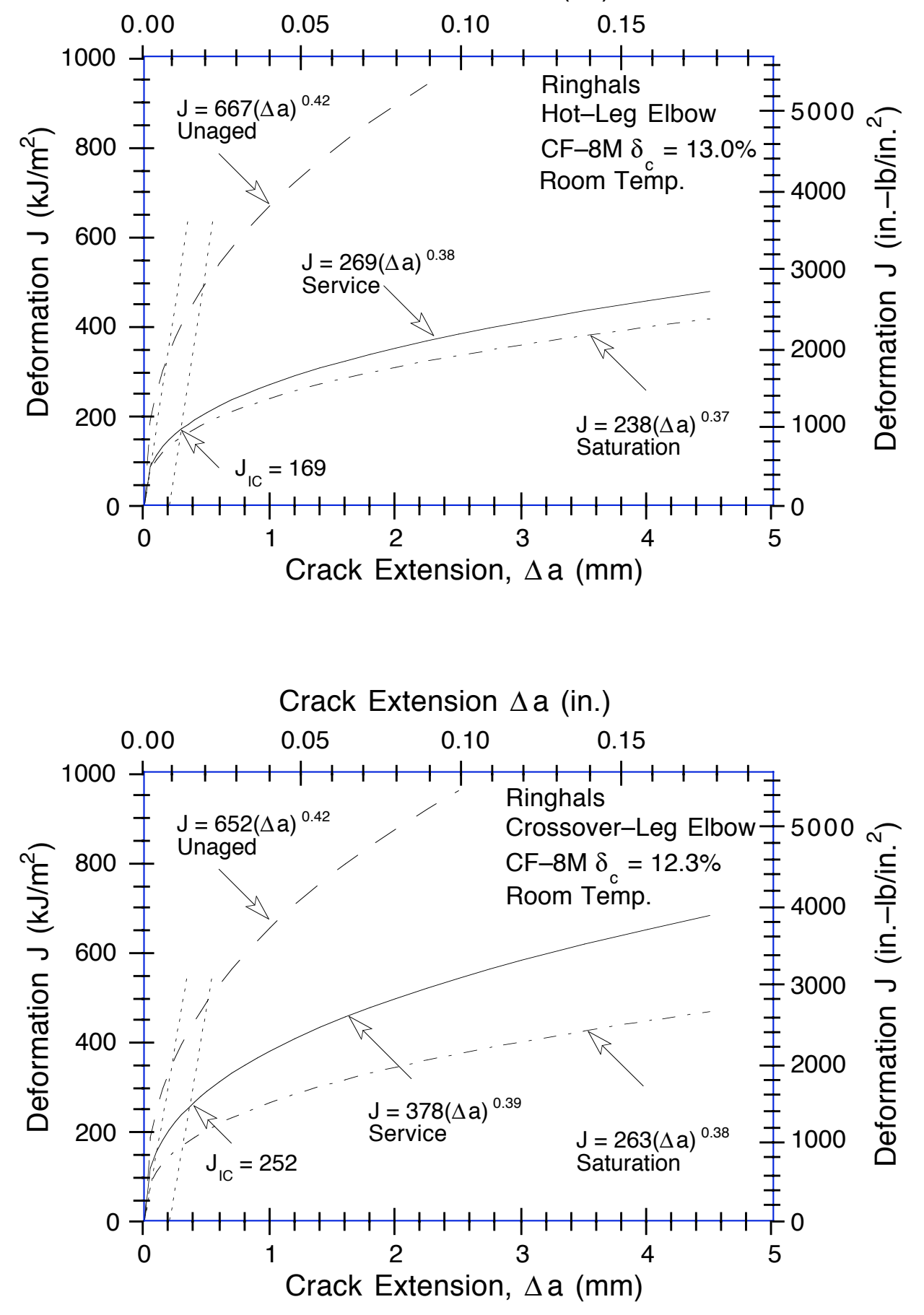

Figure 35. Estimated fracture toughness $J-R$ curves for the Ringhals hotand crossover-leg elbows in the unaged condition, after service, and at saturation. (Dashed, solid, and chain-dot lines are the estimated power-law $\mathrm{J}-R$ curves for unaged, service-aged, and fully embrittled or aged material, respectively.) 


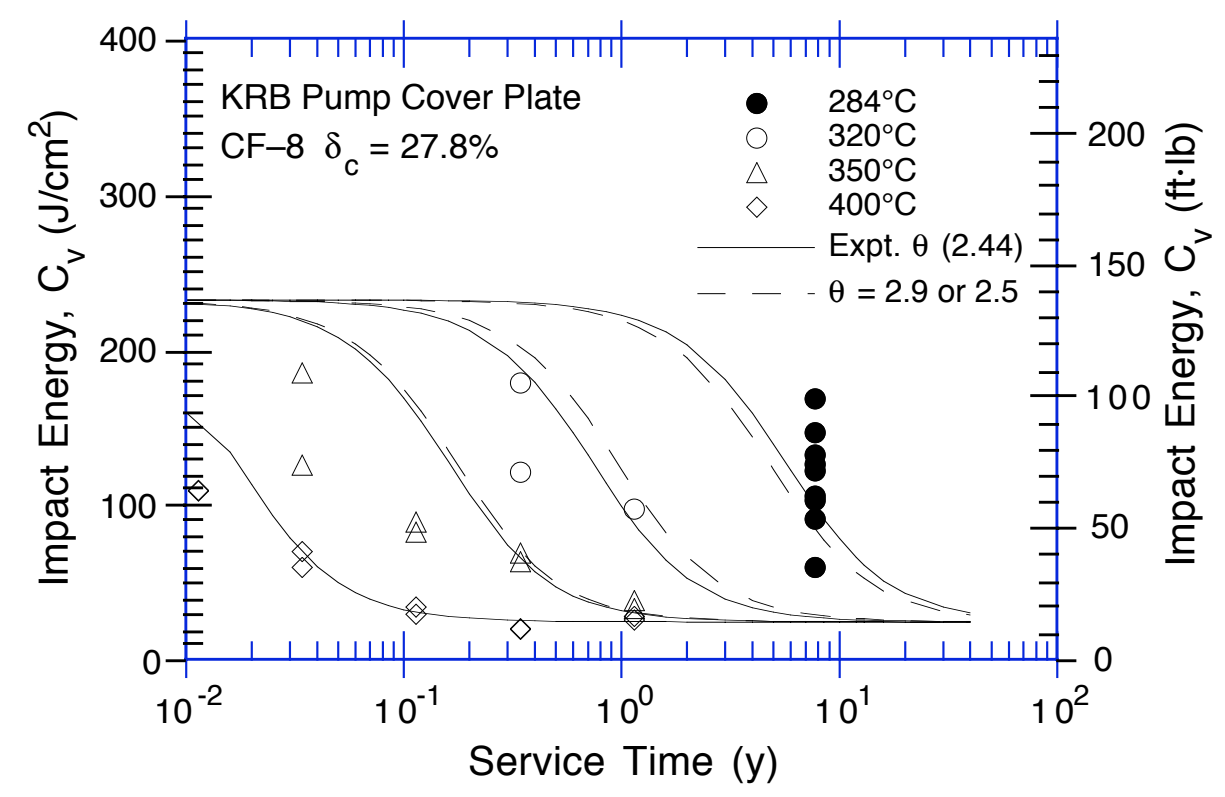

Figure 36. Variation of estimated room-temperature Charpy-impact energy with service time for the KRB pump cover plate

The estimated and measured tensile stress-vs.-strain curves for annealed and service-aged material are presented in Fig. 37. The estimates show very good agreement with the test results. Information on the chemical composition and initial Charpy-impact energy and tensile strength of the unaged materials was used in these estimations.

Fracture toughness $\mathrm{J}-\mathrm{R}$ curves for the material in the unaged or annealed condition, after service for $\approx 8 \mathrm{y}$ at $284^{\circ} \mathrm{C}$ and at saturation, were determined from the estimated impact energies for the specific aging condition and are shown in Fig. 38. The JIC values at room temperature and $290^{\circ} \mathrm{C}$ were also obtained from the estimated $\mathrm{J}-\mathrm{R}$ curve and tensile flow stress; results are given in Table 4. The estimated fracture toughness shows good agreement with the measured value at room temperature and is somewhat lower at $290^{\circ} \mathrm{C}$.

\section{Conclusions}

Charpy-impact, tensile, and fracture toughness properties of several cast SS materials from the Shippingport reactor have been characterized. Baseline mechanical properties for the unaged material were determined from tests on either recovery-annealed material, i.e., material that had been annealed for $1 \mathrm{~h}$ at $550^{\circ} \mathrm{C}$ and then water quenched, or on material from a cooler region of the component. The Shippingport materials exhibit modest degradation of mechanical properties because of the relatively low operating temperatures and/or low ferrite content of the materials.

Thermal aging during $\approx 15 \mathrm{y}$ of reactor service had no effect on yield stress and the increase in ultimate stress is minimal for all materials. The RT Charpy-impact energy decreased from 188 to $145 \mathrm{~J} / \mathrm{cm}^{2}$ (111 to $86 \mathrm{ft} \cdot \mathrm{lb}$ ) for the check valve CA4, from 320 to $299 \mathrm{~J} / \mathrm{cm}^{2}$ (189 to $176 \mathrm{ft} \cdot \mathrm{lb}$ ) for the main valve MA1, and from 424 to $322 \mathrm{~J} / \mathrm{cm}^{2}$ (250 to $190 \mathrm{ft} \cdot \mathrm{lb}$ ) for the pump volute PV. However, the RT Charpy-impact energies of the materials are relatively high and the 

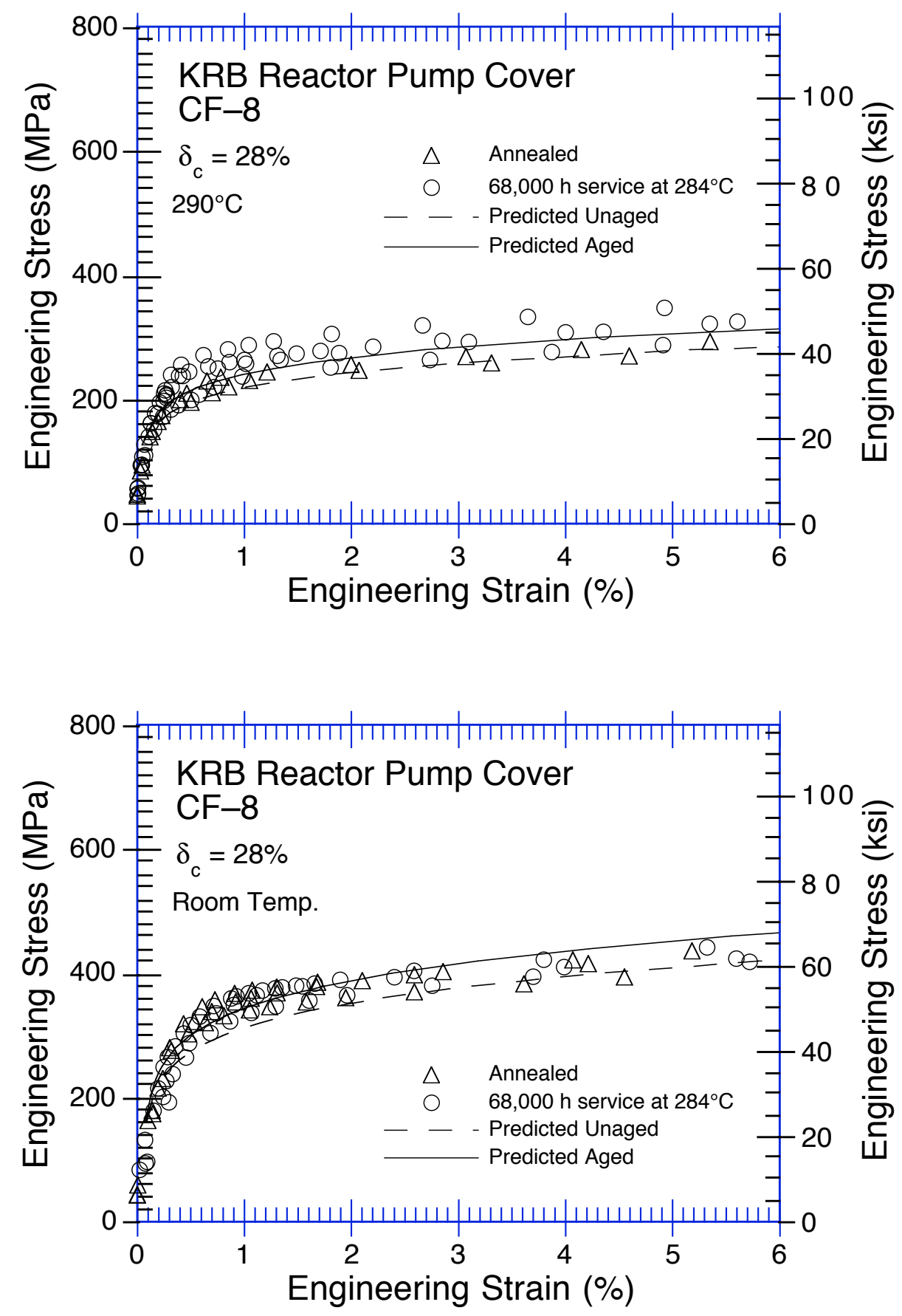

Figure 37. Estimated and measured tensile stress-vs.-strain curves at room temperature and $290^{\circ} \mathrm{C}$ for the KRB pump cover plate in the annealed condition and after $8 y$ of service at $284^{\circ} \mathrm{C}$ 

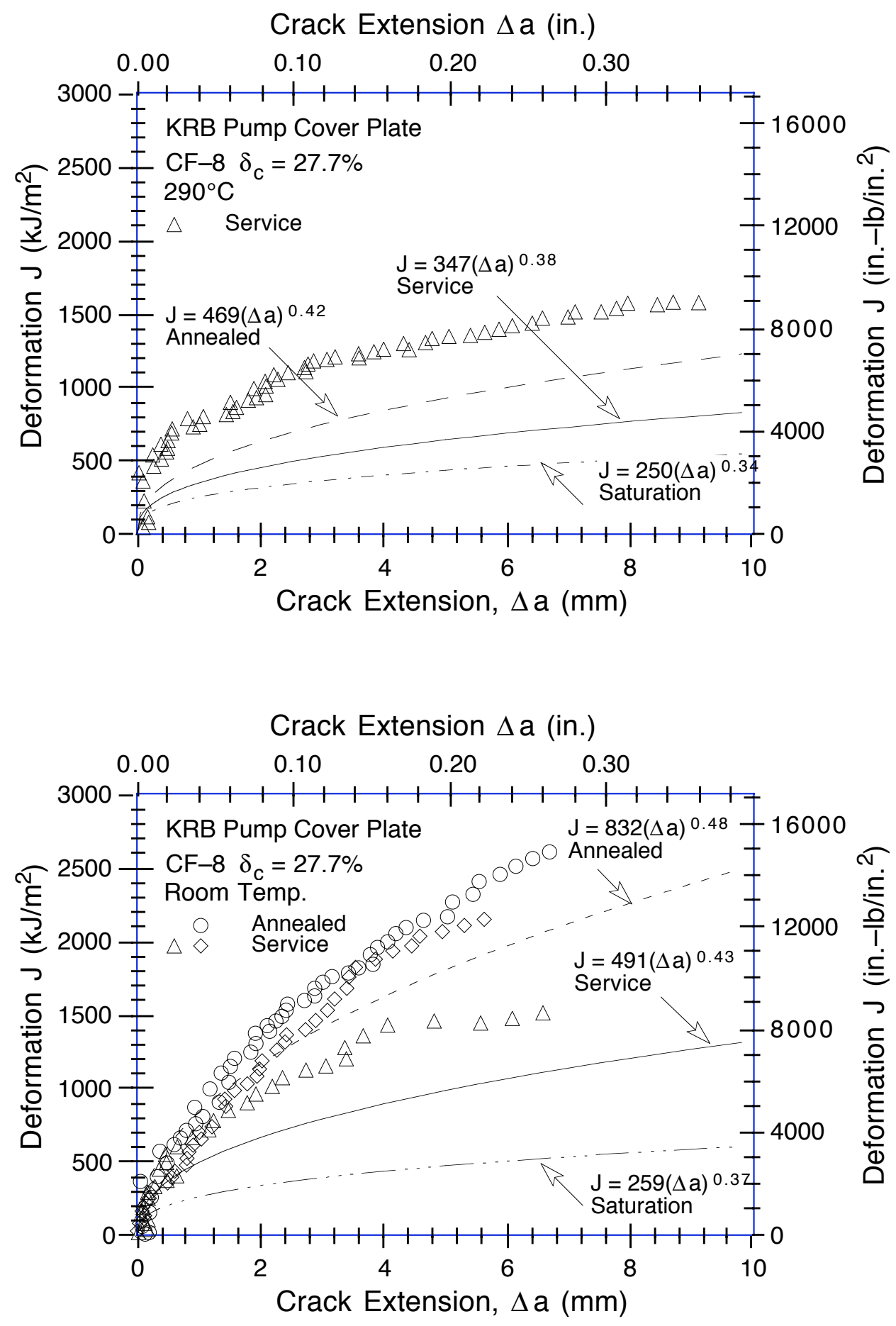

Figure 38. Estimated and measured fracture toughness $J-R$ curve for the $K R B$ pump cover plate in the annealed or unaged condition, after service, and at saturation. (Dashed, solid, and chain-dot lines are the estimated power-law $J-R$ curves for annealed, service-aged, and fully embrittled or aged material, respectively.) 
mid-shelf CTTs are very low. The check valve materials CA4 and CB7 are weaker than the material from the main valve MA1 and pump volute PV. Also, the mid-shelf CTT is $\approx 100^{\circ} \mathrm{C}$ higher for the check valves because of the presence of phase-boundary carbides that weaken the phase boundaries and thereby promote failure by phase-boundary separation. The results also indicate that the decrease in fracture toughness from reactor service is minimal.

Some materials were aged further in the laboratory to obtain the kinetics of embrittlement and determine the saturation or minimum fracture properties for the specific material. The results indicate that the Shippingport cast SSs are not very susceptible to thermal embrittlement at reactor operating temperatures. Even at saturation or fully embrittled condition, the RT impact energy of the materials is $>60 \mathrm{~J} / \mathrm{cm}^{2}$ (>35 ft.lb) and the $R T J_{d}$ value is $>600 \mathrm{~kJ} / \mathrm{m}^{2}$ (>3400 in. $-\mathrm{lb} / \mathrm{in} .^{2}$ ) at $5-\mathrm{mm}$ crack extension.

The results are compared with estimations based on accelerated laboratory aging studies. The procedure and correlations developed at ANL for estimating thermal aging degradation of cast SSs predicted accurate or slightly conservative values for Charpy-impact energy, tensile flow stress, fracture toughness $J-R$ curve, and $J_{I C}$ for the Shippingport materials. For example, the correlations predicted only modest decreases in Charpy-impact energy and fracture toughness of the materials after service. The somewhat conservative estimates are expected for some compositions of cast SSs because the criteria used in developing the estimation scheme ensure that the estimated mechanical properties are adequately conservative for cast SSs as defined by ASTM Specification A-351. The correlations do not consider the effects of metallurgical differences that may arise from differences in production heat treatment or casting processes and, therefore, are somewhat conservative for some steels. The correlations successfully predicted the mechanical properties of the Ringhals reactor hot- and crossover-leg elbows after $\approx 15 \mathrm{y}$ of service and of the KRB reactor pump cover plate after $\approx 8 \mathrm{y}$ of service.

\section{References}

1. O. K. Chopra and H. M. Chung, "Aging Degradation of Cast Stainless Steels: Effects on Mechanical Properties," in Environmental Degradation of Materials in Nuclear Power Systems-Water Reactors, G. J. Theus and J. R. Weeks, eds., The Metallurgical Society, Warrendale, PA, pp. 737-748 (1988).

2. O. K. Chopra and H. M. Chung, "Effect of Low-Temperature Aging on the Mechanical Properties of Cast Stainless Steels," in Properties of Stainless Stee/s in Elevated-Temperature Service, M. Prager, ed., MPC Vol. 26, PVP Vol. 132, ASME, New York, pp. 79-105 (1988).

3. O. K. Chopra, "Thermal Aging of Cast Stainless Steels: Mechanisms and Predictions," in Fatigue, Degradation, and Fracture - 1990, W. H. Bamford, C. Becht, S. Bhandari, J. D. Gilman, L. A. James, and M. Prager, eds., MPC Vol. 30, PVP Vol. 195, ASME, New York, pp. 193-214 (1990).

4. O. K. Chopra and A. Sather, Initial Assessment of the Mechanisms and Significance of Low-Temperature Embrittlement of Cast Stainless Steels in LWR Systems, NUREG/CR-5385, ANL-89/17 (August 1990). 
5. O. K. Chopra, "Thermal Aging of Cast Stainless Steels in LWR Systems: Estimation of Mechanical Properties," in Nuclear Plant Systems/Components Aging Management and Life Extension, I. T. Kisisel, J. Sinnappan, R. W. Carlson, and W. H. Lake, eds., PVP Vol. 228, ASME, New York, pp. 79-92 (1992).

6. O. K. Chopra, Estimation of Fracture Toughness of Cast Stainless Steels during Thermal Aging in LWR Systems - Revision 1, NUREG/CR-4513 Rev. 1, ANL-93/22 (August 1994).

7. O. K. Chopra and W. J. Shack, Assessment of Thermal Embrittlement of Cast Stainless Steels, NUREG/CR-6177, ANL-94/2 (May 1994).

8. W. F. Michaud, P. T. Toben, W. K. Soppet, and O. K. Chopra, Tensile-Property Characterization of Thermally Aged Cast Stainless Steels, NUREG/CR-6142, ANL-93/35 (February 1994).

9. A. Trautwein and W. Gysel, "Influence of Long-Time Aging of CF-8 and CF-8M Cast Steel at Temperatures Between 300 and $500^{\circ} \mathrm{C}$ on the Impact Toughness and the Structure Properties," in Spectrum, Technische Mitteilungen aus dem+GF+Konzern, No. 5 (May 1981); also in Stainless Steel Castings, V. G. Behal and A. S. Melilli, eds., STP 756, ASTM, Philadelphia, PA, pp. 165-189 (1982).

10. E. I. Landerman and W. H. Bamford, "Fracture Toughness and Fatigue Characteristics of Centrifugally Cast Type 316 Stainless Steel Pipe after Simulated Thermal Service Conditions," in Ductility and Toughness Considerations in Elevated-Temperature Service, MPC 8, ASME, New York, pp. 99-127 (1978).

11. S. Bonnet, J. Bourgoin, J. Champredonde, D. Guttmann, and M. Guttmann, "Relationship between Evolution of Mechanical Properties of Various Cast Duplex Stainless Steels and Metallurgical and Aging Parameters: An Outline of Current EDF Programmes," Mater. Sci. Technol., 6, 221-229 (1990).

12. P. H. Pumphrey and K. N. Akhurst, "Aging Kinetics of CF3 Cast Stainless Steel in Temperature Range 300-400 C," Mater. Sci. Technol., 6, 211-219 (1990).

13. G. Slama, P. Petrequin, and T. Mager, "Effect of Aging on Mechanical Properties of Austenitic Stainless Steel Castings and Welds," presented at SMIRT Post-Conference Seminar 6, Assuring Structural Integrity of Steel Reactor Pressure Boundary Components, Aug. 29-30, 1983, Monterey, CA.

14. Y. Meyzaud, P. Ould, P. Balladon, M. Bethmont, and P. Soulat, "Tearing Resistance of Aged Cast Austenitic Stainless Steel," presented at Int. Conf. on Thermal Reactor Safety (NUCSAFE 88), Oct. 1988, Avignon, France.

15. P. McConnell and J. W. Sheckherd, Fracture Toughness Characterization of Thermally Embrittled Cast Duplex Stainless Steel, Report NP-5439, Electric Power Research Institute, Palo Alto, CA (September 1987).

16. G. E. Hale and S. J. Garwood, "The Effect of Aging on the Fracture Behaviour of Cast Stainless Steel and Weldments," Mater. Sci. Technol., 6, 230-235 (1990). 
17. C. Jansson, "Degradation of Cast Stainless Steel Elbows after 15 Years in Service," presented at Fontevraud // Int. Symp., Sept. 10-14, 1990, Royal Abbey of Fontevraud, France.

18. H. M. Chung, "Thermal Aging of Decommissioned Reactor Cast Stainless Steel Components and Methodology for Life Prediction," in Life Assessment and Life Extension of Power Plant Components, T. V. Narayanan, C. B. Bond, J. Sinnappan, A. E. Meligi, M. Prager, T. R. Mager, J. D. Parker, and K. Means, eds., PVP Vol. 171, ASME, New York, pp. 111-125 (1989).

19. H. M. Chung and T. R. Leax, "Embrittlement of Laboratory and Reactor Aged CF3, CF8, and CF8M Duplex Stainless Steels," Mater. Sci. and Technol. 6, 249-262 (1990).

20. W. H. Shack, O. K. Chopra, and H. M. Chung, "Aging Studies on Materials from the Shippingport Reactor," in Compilation of Contract Research for the Materials Engineering Branch, Division of Engineering: Annual Report for FY 1988, NUREG-0975, Vol. 7, p. 218 (May 1989).

21. O. K. Chopra, "Studies of Aged Cast Stainless Steel from the Shippingport Reactor," in Proc. 18th Water Reactor Safety Information Meeting, U.S. Nuclear Regulatory Commission, NUREG/CP-0114 Vol. 3, p. 369 (April 1991).

22. O. K. Chopra, "Evaluation of Aging Degradation of Structural Components," in Proc. of the Aging Research Information Conference, NUREG/CP-0122, Vol. 2, pp. 369-386 (1992).

23. W. L. Server, "Impact Three-Point Bend Testing for Notched and Precracked Specimens," J. Testing and Eval. 6, 29 (1978).

24. L. S. Aubrey, P. F. Wieser, W. J. Pollard, and E. A. Schoefer, "Ferrite Measurement and Control in Cast Duplex Stainless Steel," in Stainless Steel Castings, V. G. Behal and A. S. Melilli, eds., ASTM STP 756, pp. 126-164 (1982). 
NUREG/CR-6275 


\section{Appendix A}

\section{Charpy-Impact Energy}

Charpy-impact tests were conducted on Charpy-impact V-notch specimens (Fig. A-1) according to American Society for Testing and Materials (ASTM) Specification E 23. A Dynatup Model 8000A drop-weight impact machine with an instrumented tup and data readout system was used for the Charpy-impact tests. The available energy and impact velocity of the machine can be varied by altering the weight of the crosshead and the drop height; maximum energy and velocity obtainable with the machine were $1.3 \mathrm{~kJ}$ and $4 \mathrm{~m} / \mathrm{s}$, respectively. Load- and energy-time data were obtained from an instrumented tup and recorded on a dual-beam storage oscilloscope. The instrumented tup consists of a striking head and a strain gauge with a four-arm semiconductor bridge circuit. The strain gauge, which measures the compressive load on the tup during the test, was calibrated by a dynamic loading technique. Initial and final velocities of the tup were measured optically. The load-time traces from each test were digitized and stored on a floppy disk for analysis. Total energy was computed from the load-time trace; the value was corrected for the effects of tup velocity.

The instrumented tup and data readout instrumentation were periodically calibrated by fracturing standard V-notch specimens fabricated from 6061-T6 aluminum and 4340 steel with a hardness of Rockwell $R_{C}$ 54. Amplifier gain was adjusted from the load- and energy-time traces for the aluminum specimen so that the recorded load limit coincided with the load limit for the material (i.e., $7.74 \mathrm{kN}$ ). The linearity of the calibration was established from the results for the 4340 steel specimen, which has a higher limit load. Accuracy of the impact-test
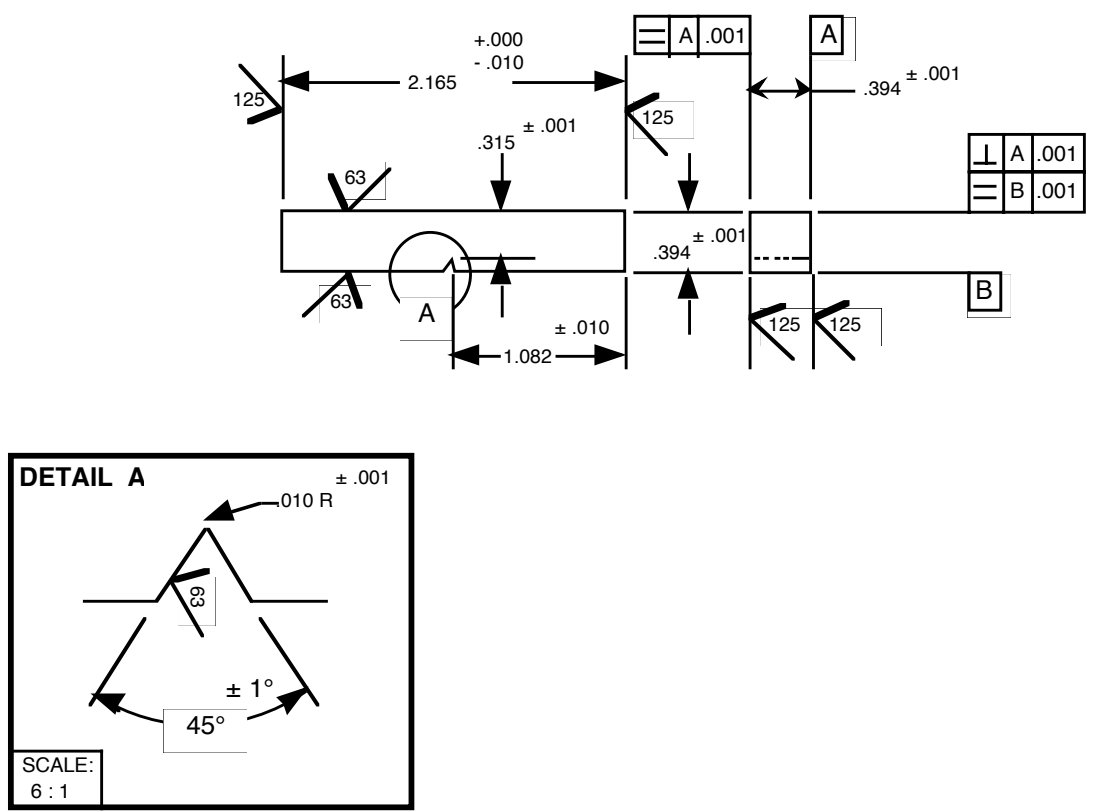

Figure A-1. Configuration of Charpy-impact test specimen: units of measure are inches 
machine was also checked periodically with Standard Reference Materials 2092 and 2096 (with Charpy-impact energies of 16.41 and $104.12 \mathrm{~J}$, respectively) obtained from the National Institute of Standards and Technology. Tests on the reference materials were performed at $-40^{\circ} \mathrm{C}\left(-40^{\circ} \mathrm{F}\right)$ in accordance with the testing procedures of Section 11 of ASTM E 23.

The specimens for high-temperature tests were heated by resistance heating. Pneumatic clamps were used to make electrical connections and hold the specimens in position on the anvils. The anvils were electrically insulated from the base plate. Power to the specimen was interrupted immediately before impact to release the clamps and remove any constraint on the specimen. The temperature was monitored and controlled by a thermocouple attached to the specimen. Specimens for the low-temperature tests were cooled in either a refrigerated bath or liquid nitrogen.

Charpy-impact test specimens were obtained from different locations across the thickness of the various components. Baseline mechanical properties for the unaged materials were obtained from either the material from a cooler region of the component or from recovery-annealed material, i.e., service-aged material that has been annealed for $1 \mathrm{~h}$ at $550^{\circ} \mathrm{C}\left(1022^{\circ} \mathrm{F}\right)$ and then water-quenched. Some materials were aged further in the laboratory, at 320, 350, and $400^{\circ} \mathrm{C}\left(608,662\right.$, and $\left.752^{\circ} \mathrm{F}\right)$, to validate the estimates of the saturation impact energy $\mathrm{C}_{V}$ sat and activation energy for embrittlement of the materials. The results are listed in Tables A-1 and A-2.

The values of $0.2 \%$ yield and maximum load for each test are also listed in Tables A-1 and A-2, and may be used for estimating tensile properties of the cast materials. For a Charpy specimen, the yield stress is estimated from the expression

$$
\sigma_{y}=\mathrm{CPy} \mathrm{B} / \mathrm{Wb}^{2} \text {, }
$$

taken from Ref. A-1, where Py is the yield load, $W$ is the specimen width, $B$ is the specimen thickness, $\mathrm{b}$ is the uncracked ligament, and $\mathrm{C}$ is a constant. The yield load was obtained from the load-time traces of the Charpy tests. Deviation from linearity in the load-time trace occurred at 125-150 $\mu$ s for the various heats. The load at $200 \mu \mathrm{s}$ was estimated to represent a $0.2 \%$ yield stress. The actual time for $0.2 \%$ yield varies with the strain hardening rate of the material; the load at $0.2 \%$ yield can be obtained from a power-law fit of the data. The error in the estimated values was $<5 \%$ for the various tests. The ultimate stress was also obtained from the impact data by means of Eq. $\mathrm{A}-1$ and the maximum load $\mathrm{Pm}$. The constant $\mathrm{C}$ was determined by comparing the tensile and Charpy-impact data. The best value of the constant for yield stress was 1.50 for steels of all grades. The constant for ultimate stress was 2.28 for CF-3 and CF-8 steels and 2.54 for CF-8M steel. The estimated values of tensile stress are based on the assumption that strain rate effects are insignificant for the various heats and aging conditions. Equation $\mathrm{A}-1$ should not be used for estimating ultimate stress at temperatures corresponding to the lower-shelf and transition regions.

\section{References}

A-1. W. L. Server, "Impact Three-Point Bend Testing for Notched and Precracked Specimens," J. Test. Eval., 6, 29 (1978). 
Table A-1. Charpy-impact test results for cast stainless steel materials from the Shippingport reactor

\begin{tabular}{|c|c|c|c|c|c|c|c|c|}
\hline \multirow{2}{*}{$\begin{array}{c}\text { Specimen } \\
\text { ID }\end{array}$} & \multirow{2}{*}{$\begin{array}{c}\text { Material } \\
\text { ID }^{\mathrm{a}}\end{array}$} & \multirow{2}{*}{$\begin{array}{l}\text { Temp. } \\
\left({ }^{\circ} \mathrm{C}\right) \\
\end{array}$} & \multicolumn{2}{|c|}{ Impact Energy } & \multicolumn{2}{|c|}{ Yield Load } & \multicolumn{2}{|c|}{ Maximum Load } \\
\hline & & & $\left(\mathrm{J} / \mathrm{cm}^{2}\right)$ & $(f t \cdot l b)^{b}$ & $(\mathrm{kN})$ & $(\mathrm{kip})$ & $(\mathrm{kN})$ & $(\mathrm{kip})$ \\
\hline \multicolumn{9}{|c|}{ Reactor Service ${ }^{\mathrm{C}}$} \\
\hline CA43-01 & CA4 & -197 & 31.1 & 18.3 & 13.192 & 2.966 & 15.213 & 3.420 \\
\hline CA41-01 & CA4 & -100 & 28.1 & 16.6 & 12.391 & 2.786 & 12.391 & 2.786 \\
\hline CA43-03 & CA4 & -78 & 33.8 & 19.9 & 10.995 & 2.472 & 12.420 & 2.792 \\
\hline CA42-02 & CA4 & -50 & 114.1 & 67.3 & 11.522 & 2.590 & 17.332 & 3.896 \\
\hline CA42-01 & CA4 & -20 & 126.8 & 74.8 & 10.946 & 2.461 & 16.854 & 3.789 \\
\hline CA44-01 & CA4 & 0 & 84.3 & 49.7 & 10.145 & 2.281 & 14.051 & 3.159 \\
\hline CA41-02 & CA4 & 25 & 162.1 & 95.6 & 9.354 & 2.103 & 15.535 & 3.492 \\
\hline CA44-02 & CA4 & 25 & 128.5 & 75.8 & 9.589 & 2.156 & 14.881 & 3.345 \\
\hline CA43-04 & CA4 & 50 & 138.2 & 81.5 & 8.427 & 1.894 & 13.211 & 2.970 \\
\hline CA43-02 & CA4 & 75 & 202.8 & 119.7 & 7.948 & 1.787 & 13.582 & 3.053 \\
\hline CA41-03 & CA4 & 125 & 281.4 & 166.0 & 7.118 & 1.600 & 13.123 & 2.950 \\
\hline CA44-03 & CA4 & 200 & 183.3 & 108.1 & 6.142 & 1.381 & 11.473 & 2.579 \\
\hline CA42-03 & CA4 & 290 & 179.0 & 105.6 & 5.546 & 1.247 & 9.891 & 2.224 \\
\hline CA43-05 & CA4 & 290 & 178.9 & 105.6 & 5.390 & 1.212 & 10.419 & 2.342 \\
\hline CB72-01 & CB7 & -197 & 73.6 & 43.4 & 12.430 & 2.794 & 18.601 & 4.182 \\
\hline CB71-01 & CB7 & -100 & 83.8 & 49.4 & 11.717 & 2.634 & 16.531 & 3.716 \\
\hline CB72-02 & CB7 & -50 & 107.0 & 63.1 & 10.956 & 2.463 & 15.369 & 3.455 \\
\hline CB71-02 & CB7 & -20 & 142.4 & 84.0 & 10.262 & 2.307 & 16.922 & 3.804 \\
\hline CB73-01 & CB7 & 0 & 211.2 & 124.6 & 8.983 & 2.019 & 15.428 & 3.468 \\
\hline CB71-03 & CB7 & 25 & 162.4 & 95.8 & 9.022 & 2.028 & 14.012 & 3.150 \\
\hline CB73-02 & CB7 & 25 & 203.7 & 120.2 & 8.700 & 1.956 & 14.666 & 3.297 \\
\hline CB73-03 & CB7 & 50 & 269.4 & 158.9 & 7.733 & 1.738 & 13.592 & 3.056 \\
\hline CB73-03 & CB7 & 75 & 295.9 & 174.6 & 7.489 & 1.684 & 13.592 & 3.056 \\
\hline CB73-04 & CB7 & 100 & 304.6 & 179.7 & 6.454 & 1.451 & 11.317 & 2.544 \\
\hline CB71-04 & CB7 & 125 & 241.5 & 142.5 & 6.874 & 1.545 & 12.313 & 2.768 \\
\hline CB72-05 & CB7 & 200 & 339.3 & 200.2 & 5.458 & 1.227 & 11.464 & 2.577 \\
\hline CB71-05 & CB7 & 290 & 292.1 & 172.3 & 5.097 & 1.146 & 10.712 & 2.408 \\
\hline CB72-04 & CB7 & 290 & 256.1 & 151.1 & 5.488 & 1.234 & 10.302 & 2.316 \\
\hline CC43-02 & $\mathrm{CC} 4$ & -197 & 26.5 & 15.6 & 12.850 & 2.878 & 12.850 & 2.889 \\
\hline CC44-01 & $\mathrm{CC} 4$ & -120 & 39.1 & 23.1 & 14.022 & 3.152 & 14.022 & 3.152 \\
\hline CC44-03 & $\mathrm{CC4}$ & 0 & 104.2 & 61.5 & 10.458 & 2.351 & 14.041 & 3.157 \\
\hline CC43-03 & $\mathrm{CC} 4$ & 25 & 121.7 & 71.8 & 9.686 & 2.177 & 14.198 & 3.192 \\
\hline CC44-02 & $\mathrm{CC} 4$ & 125 & 216.3 & 127.6 & 7.079 & 1.591 & 12.186 & 2.740 \\
\hline CC43-01 & $\mathrm{CC4}$ & 290 & 306.3 & 180.7 & 5.605 & 1.260 & 11.239 & 2.527 \\
\hline MA11-05 & MA1 & -197 & 49.4 & 29.1 & 13.924 & 3.130 & 15.115 & 3.398 \\
\hline MA11-01 & MA1 & -100 & 190.6 & 112.5 & 13.026 & 2.928 & 21.902 & 4.924 \\
\hline MA11-02 & MA1 & -20 & 228.8 & 135.0 & 9.764 & 2.195 & 16.580 & 3.727 \\
\hline MA11-03 & MA1 & 25 & 144.5 & 85.3 & 10.106 & 2.272 & 14.207 & 3.194 \\
\hline MA11-06 & MA1 & 25 & 210.0 & 123.9 & 8.524 & 1.916 & 14.325 & 3.220 \\
\hline MA11-04 & MA1 & 125 & 167.0 & 98.5 & 8.671 & 1.949 & 12.889 & 2.898 \\
\hline MA12-01 & MA1 & -197 & 96.9 & 57.2 & 12.001 & 2.698 & 19.148 & 4.305 \\
\hline MA12-05 & MA1 & -120 & 149.3 & 88.1 & 11.649 & 2.619 & 18.631 & 4.188 \\
\hline MA13-04 & MA1 & -100 & 318.6 & 188.0 & 11.561 & 2.599 & 22.185 & 4.987 \\
\hline MA12-02 & MA1 & -50 & 281.1 & 165.8 & 10.887 & 2.447 & 18.025 & 4.052 \\
\hline MA13-01 & MA1 & 0 & 293.7 & 173.3 & 10.399 & 2.338 & 16.346 & 3.675 \\
\hline MA12-06 & MA1 & 25 & 279.2 & 164.7 & 8.817 & 1.982 & 14.959 & 3.363 \\
\hline MA13-02 & MA1 & 25 & 337.6 & 199.2 & 9.237 & 2.077 & 15.877 & 3.569 \\
\hline MA13-05 & MA1 & 25 & 280.7 & 165.6 & 9.032 & 2.030 & 15.174 & 3.411 \\
\hline MA12-03 & MA1 & 75 & 249.0 & 146.9 & 7.577 & 1.703 & 13.143 & 2.955 \\
\hline MA13-06 & MA1 & 125 & 269.3 & 158.9 & 6.532 & 1.468 & 12.284 & 2.762 \\
\hline MA12-07 & MA1 & 200 & 227.8 & 134.4 & 5.468 & 1.229 & 11.063 & 2.487 \\
\hline
\end{tabular}


Table A-1. (Contd.)

\begin{tabular}{|c|c|c|c|c|c|c|c|c|}
\hline \multirow{2}{*}{$\begin{array}{c}\text { Specimen } \\
\text { ID }\end{array}$} & \multirow{2}{*}{$\begin{array}{c}\text { Material } \\
I^{a}\end{array}$} & \multirow{2}{*}{$\begin{array}{l}\text { Temp. } \\
\left({ }^{\circ} \mathrm{C}\right) \\
\end{array}$} & \multicolumn{2}{|c|}{ Impact Energy } & \multicolumn{2}{|c|}{ Yield Load } & \multicolumn{2}{|c|}{ Maximum Load } \\
\hline & & & 2 & & $(\mathrm{kN})$ & $(\mathrm{kip})$ & $(\mathrm{kN})$ & kip) \\
\hline MA13-07 & MA1 & 200 & 231.7 & 136.7 & 6.786 & 1.526 & 11.551 & 597 \\
\hline 12-04 & MA1 & 290 & 197.6 & 116.6 & 6.318 & 1.420 & 10.594 & 382 \\
\hline & IA1 & 290 & 75.2 & 103.4 & & 1.159 & & \\
\hline MA91-01 & A99 & 197 & 6.8 & 39.4 & 14.412 & 3.240 & 17.361 & 903 \\
\hline & AA9 & 197 & 06.2 & 62.7 & 12.625 & 2.838 & 19.617 & 410 \\
\hline MA92-01 & MA9 & -120 & 252.4 & 148.9 & 12.938 & 2.909 & 20.720 & 658 \\
\hline MA94-01 & MA9 & -120 & 116.2 & 68.6 & 11.766 & 2.645 & 16.746 & 3.765 \\
\hline MA91-02 & MA9 & -100 & 2.3 & 125.3 & 12.069 & 2.713 & 19. & \\
\hline MA93-02 & MA9 & -100 & 10.7 & 124.3 & 11.317 & 2.544 & 19.168 & 4.309 \\
\hline MA92-02 & MA9 & -78 & 295.5 & 174.3 & 11.249 & 2.529 & 19.226 & 4.322 \\
\hline MA94-02 & MA9 & -78 & 1.2 & 106.9 & 10.184 & 2.289 & 18. & 4.173 \\
\hline MA91-03 & MA9 & -50 & 9.7 & 176.8 & 9.940 & & 17. & 894 \\
\hline MA93-03 & MA9 & -50 & 314.7 & 185.7 & 10.878 & 2.445 & 18.006 & 4.048 \\
\hline MA92-03 & MA9 & -20 & 9.1 & 259.1 & & 2.070 & 16. & 3.745 \\
\hline & $M \triangle O$ & 20 & & 242.8 & & 2.219 & 16. & .778 \\
\hline-04 & & 0 & & 196.3 & & & 14. & 52 \\
\hline MA94-04 & MA9 & 10 & 0.2 & 218.4 & & 2.004 & 14. & 339 \\
\hline & & & & & & & 15. & \\
\hline & & 2 & & & & 2.022 & 15. & \\
\hline MA92-05 & MA9 & 75 & 316.7 & 186.9 & 7.401 & 1.664 & 13.465 & 3.027 \\
\hline-05 & MA9 & 7 & .1 & .1 & & 1.624 & 13. & 83 \\
\hline-05 & MA9 & 25 & 8.5 & 199.7 & & 1.576 & 13. & 66 \\
\hline-06 & MA9 & 125 & 9.8 & 153.3 & 18 & 1.510 & 11.971 & 2.691 \\
\hline & & & & & & 1.2 & 11. & \\
\hline & $M$ & 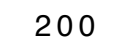 & 1.3 & 148.3 & & 1.236 & 11. & 73 \\
\hline MA91-06 & MA9 & 290 & 46.4 & 145.4 & 5.927 & 1.332 & 9.8 & 2.215 \\
\hline MA93-06 & MA9 & 290 & & 138.8 & & 1.209 & & 2.226 \\
\hline $\mathrm{PV} 1$ & DY & -197 & 3.5 & 6.9 & 6 & 2.645 & 18 & 4.215 \\
\hline & & 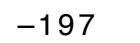 & & .2 & & & 20 & \\
\hline & & -12 & .5 & 113.6 & 54 & 2.575 & 20. & \\
\hline PV1 & PI & -100 & 256.4 & 151.3 & 11.522 & 2.590 & 19.841 & 4.460 \\
\hline & & -100 & & 174.5 & 11. & 2.520 & 21. & 4.726 \\
\hline & & -5 & .4 & .7 & 1 & 2.318 & 19. & 4.294 \\
\hline & $P V$ & -20 & 8.2 & 199.5 & 10.917 & 2.454 & 18.025 & 4.052 \\
\hline & PY & -20 & 374.2 & 220.8 & & 2.241 & 17.781 & 3.997 \\
\hline & & & & & & 1.991 & 15. & 3.398 \\
\hline & $P V$ & 2 & 6.9 & 187.0 & 17 & 1.982 & 15.106 & 3.396 \\
\hline & PV & 25 & 37.3 & 199.0 & & 1.846 & 14.666 & 3.297 \\
\hline & & & & & & 1.765 & 14. & 3.183 \\
\hline & 政 & 1 & .6 & .0 & & 1.3 & 12. & 2.779 \\
\hline PV2-05 & PV & 175 & 342.1 & 201.8 & 6.240 & 1.403 & 11.229 & 2.524 \\
\hline & & & & & & 1.271 & 11.1 & 2.498 \\
\hline & & & & & & 1.229 & 10 & 1320 \\
\hline & PV & & .8 & & & 1.201 & 9.345 & 2.101 \\
\hline PV3-06 & PV & 290 & 275.6 & 162.6 & 5.322 & 1.196 & 9.550 & 2.147 \\
\hline PV6-01 & PV & -197 & .6 & 44.0 & 11. & 2.544 & 16.277 & 3.659 \\
\hline & PV & 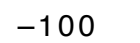 & .5 & 113.6 & 4 & 2.575 & 20. & 4.618 \\
\hline & & & & 150.6 & & 2.459 & 16.5 & \\
\hline & PV & 25 & 262.4 & 154.8 & & 2.099 & 15.496 & 3.484 \\
\hline PV6-05 & PV & 175 & 235.6 & 139.0 & 7.021 & 1.578 & 12.284 & 2.762 \\
\hline PV6-06 & PV & 290 & 278.6 & 164.4 & 6.327 & 1.422 & 10.507 & 2.362 \\
\hline
\end{tabular}


Table A-1. (Contd.)

\begin{tabular}{|c|c|c|c|c|c|c|c|c|}
\hline \multirow{2}{*}{$\begin{array}{c}\text { Specimen } \\
\text { ID }\end{array}$} & \multirow{2}{*}{$\begin{array}{c}\text { Material } \\
\text { ID }^{\mathrm{a}}\end{array}$} & \multirow{2}{*}{$\begin{array}{r}\text { Temp. } \\
\left({ }^{\circ} \mathrm{C}\right) \\
\end{array}$} & \multicolumn{2}{|c|}{ Impact Energy } & \multicolumn{2}{|c|}{ Yield Load } & \multicolumn{2}{|c|}{ Maximum Load } \\
\hline & & & $\left(\mathrm{J} / \mathrm{cm}^{2}\right)$ & $(f t \cdot l b)^{b}$ & $(\mathrm{kN})$ & $(\mathrm{kip})$ & $(\mathrm{kN})$ & $(\mathrm{kip})$ \\
\hline \multicolumn{9}{|l|}{ Annealedd } \\
\hline CA42-10 & CA4 & -197 & 38.4 & 22.7 & 12.235 & 2.751 & 14.637 & 3.291 \\
\hline CA41-12 & CA4 & -120 & 72.7 & 42.9 & 12.293 & 2.764 & 17.478 & 3.929 \\
\hline CA44-08 & CA4 & -100 & 61.2 & 36.1 & 12.010 & 2.700 & 15.115 & 3.398 \\
\hline CA42-11 & CA4 & -50 & 93.1 & 54.9 & 10.770 & 2.421 & 16.443 & 3.697 \\
\hline CA43-11 & CA4 & -20 & 144.2 & 85.1 & 10.760 & 2.419 & 16.385 & 3.683 \\
\hline CA41-10 & CA4 & 25 & 196.1 & 115.7 & 8.593 & 1.932 & 14.373 & 3.231 \\
\hline CA42-12 & CA4 & 25 & 179.8 & 106.1 & 9.149 & 2.057 & 14.705 & 3.306 \\
\hline CA44-09 & CA4 & 75 & 191.7 & 113.1 & 8.095 & 1.820 & 13.397 & 3.012 \\
\hline CA43-10 & CA4 & 175 & 216.9 & 128.0 & 6.484 & 1.458 & 11.551 & 2.597 \\
\hline CA41-11 & CA4 & 290 & 225.3 & 132.9 & 5.331 & 1.198 & 10.321 & 2.320 \\
\hline MA11-12 & MA1 & -196 & 66.9 & 39.5 & 12.167 & 2.735 & 14.598 & 3.282 \\
\hline MA11-11 & MA1 & -120 & 119.6 & 70.6 & 10.966 & 2.465 & 14.793 & 3.326 \\
\hline MA11-10 & MA1 & -80 & 186.7 & 110.2 & 10.760 & 2.419 & 17.752 & 3.991 \\
\hline MA11-09 & MA1 & -20 & 303.2 & 178.9 & 9.804 & 2.204 & 15.194 & 3.416 \\
\hline MA11-08 & MA1 & 25 & 62.2 & 36.7 & 10.194 & 2.292 & 11.522 & 2.590 \\
\hline MA12-12 & MA1 & -196 & 156.3 & 92.2 & 12.235 & 2.751 & 21.540 & 4.842 \\
\hline MA12-11 & MA1 & -100 & & 128.8 & 11.786 & 2.650 & 19.431 & 4.368 \\
\hline MA12-10 & MA1 & -50 & 294.7 & 173.9 & 10.243 & 2.303 & 16.736 & 3.762 \\
\hline MA13-12 & MA1 & 0 & 336.1 & 198.3 & 9.003 & 2.024 & 15.526 & 3.490 \\
\hline MA12-09 & MA1 & 25 & 267.1 & 157.6 & 8.476 & 1.905 & 13.768 & 3.095 \\
\hline MA13-11 & MA1 & 75 & 334.9 & 197.6 & 8.026 & 1.804 & 13.133 & 2.952 \\
\hline MA12-09 & MA1 & 100 & 369.3 & 217.9 & 6.923 & 1.556 & 12.645 & 2.843 \\
\hline MA13-10 & MA1 & 200 & 261.6 & 154.3 & 6.376 & 1.433 & 11.922 & 2.680 \\
\hline MA13-09 & MA1 & 290 & 254.0 & 149.9 & 4.492 & 1.010 & 9.638 & 2.167 \\
\hline MA91-15 & MA9 & -197 & 3.0 & 137.5 & 12.645 & 2.843 & 24.753 & 5.565 \\
\hline MA92-15 & MA9 & -120 & 290.7 & 171.5 & 10.741 & 2.415 & 19.6 & 4.428 \\
\hline MA94-16 & MA9 & -50 & 348.9 & 205.9 & 10.643 & 2.393 & 16.922 & 3.804 \\
\hline MA95-02 & MA9 & -20 & 344.1 & 203.0 & 10.956 & 2.463 & 16.824 & 3.782 \\
\hline MA95-01 & MA9 & 25 & 388.1 & 229.0 & 9.286 & 2.088 & 14.276 & 3.209 \\
\hline MA94-17 & MA9 & 175 & 332.9 & 196.4 & 5.976 & 1.343 & 12.030 & 2.704 \\
\hline MA95-12 & MA9 & 290 & 278.5 & 164.3 & 5.781 & 1.300 & 9.774 & 2.197 \\
\hline PV1-09 & PV & -197 & 228.2 & 134.6 & 11.356 & 2.553 & 22.742 & 5.113 \\
\hline PV2-09 & PV & -197 & 233.4 & 137.7 & 10.995 & 2.472 & 22.107 & 4.970 \\
\hline PV1-10 & PV & -120 & 368.6 & 217.5 & 11.298 & 2.540 & 21.511 & 4.836 \\
\hline PV3-09 & PV & -120 & 270.7 & 159.7 & 10.887 & 2.447 & 18.797 & 4.226 \\
\hline PV1-11 & PV & -100 & 270.8 & 159.8 & 12.508 & 2.812 & 22.185 & 4.987 \\
\hline PV2-10 & PV & -100 & 160.3 & 94.6 & 11.063 & 2.487 & 16.902 & 3.800 \\
\hline PV2-11 & PV & -80 & 301.2 & 177.7 & 10.555 & 2.373 & 19.168 & 4.309 \\
\hline PV3-10 & PV & -80 & 269.3 & 158.9 & 10.262 & 2.307 & 18.416 & 4.140 \\
\hline PV3-11 & PV & -50 & 415.5 & 245.1 & 10.331 & 2.323 & 19.236 & 4.324 \\
\hline PV3-12 & PV & -20 & 322.4 & 190.2 & 9.999 & 2.248 & 15.526 & 3.490 \\
\hline PV2-12 & PV & 0 & 436.7 & 257.7 & 8.769 & 1.971 & 15.106 & 3.396 \\
\hline PV1-12 & PV & 25 & 404.6 & 238.7 & 9.032 & 2.030 & 13.885 & 3.121 \\
\hline PV2-13 & PV & 25 & 442.9 & 261.3 & 8.827 & 1.984 & 15.018 & 3.376 \\
\hline PV3-13 & PV & 75 & 375.9 & 221.8 & 7.597 & 1.708 & 13.368 & 3.005 \\
\hline PV1-13 & PV & 125 & 353.7 & 208.7 & 6.669 & 1.499 & 12.128 & 2.726 \\
\hline PV3-14 & PV & 290 & 309.1 & 182.4 & 5.576 & 1.254 & 11.444 & 2.573 \\
\hline
\end{tabular}


Table A-1. (Contd.)

\begin{tabular}{|c|c|c|c|c|c|c|c|c|}
\hline \multirow{2}{*}{$\begin{array}{c}\text { Specimen } \\
\text { ID }\end{array}$} & \multirow{2}{*}{$\begin{array}{c}\text { Material } \\
I^{a}\end{array}$} & \multirow{2}{*}{$\begin{array}{l}\text { Temp. } \\
\left({ }^{\circ} \mathrm{C}\right) \\
\end{array}$} & \multicolumn{2}{|c|}{ Impact Energy } & \multicolumn{2}{|c|}{ Yield Load } & \multicolumn{2}{|c|}{ Maximum Load } \\
\hline & & & $\left(\mathrm{J} / \mathrm{cm}^{2}\right)$ & $(f t \cdot l b)^{b}$ & $(\mathrm{kN})$ & $(\mathrm{kip})$ & $(\mathrm{kN})$ & $(\mathrm{kip})$ \\
\hline \multicolumn{9}{|c|}{ Unaged Spare Volute $\mathrm{e}$} \\
\hline VR1-02 & VR & -197 & 63.3 & 37.3 & 12.500 & 2.805 & 16.766 & 3.769 \\
\hline VR2-02 & VR & -120 & 133.3 & 78.6 & 13.534 & 3.043 & 21.091 & 4.741 \\
\hline VR2-04 & VR & -80 & 205.5 & 121.2 & 11.659 & 2.621 & 19.558 & 4.397 \\
\hline VR3-02 & VR & -50 & 240.8 & 142.1 & 13.172 & 2.961 & 20.349 & 4.575 \\
\hline VR1-03 & VR & 0 & 232.3 & 137.1 & 11.620 & 2.612 & 17.078 & 3.839 \\
\hline VR1-01 & VR & 25 & 200.0 & 118.0 & 12.479 & 2.805 & 16.766 & 3.769 \\
\hline VR3-01 & VR & 25 & 274.2 & 161.8 & 10.839 & 2.437 & 16.395 & 3.686 \\
\hline VR2-03 & VR & 75 & 194.2 & 114.6 & 9.374 & 2.107 & 13.006 & 2.924 \\
\hline VR2-01 & VR & 125 & 197.5 & 116.5 & 8.222 & 1.848 & 12.831 & 2.885 \\
\hline VR3-03 & VR & 125 & 341.3 & 201.4 & 7.851 & 1.765 & 13.504 & 3.036 \\
\hline VR3-04 & VR & 200 & 189.9 & 112.0 & 6.503 & 1.462 & 10.780 & 2.423 \\
\hline VR1-04 & VR & 290 & 263.5 & 155.5 & 6.200 & 1.394 & 10.341 & 2.325 \\
\hline \multicolumn{9}{|c|}{ Aged $10,000 \mathrm{~h}$ at $400^{\circ} \mathrm{C}$} \\
\hline MA91-10 & MA9 & -197 & 23.4 & 13.8 & 10.321 & 2.320 & 10.321 & 2.320 \\
\hline MA94-09 & MA9 & -120 & 36.0 & 21.2 & 11.737 & 2.639 & 12.372 & 2.781 \\
\hline MA91-11 & MA9 & -50 & 93.6 & 55.2 & 11.190 & 2.516 & 15.213 & 3.420 \\
\hline MA94-10 & MA9 & 0 & 113.0 & 66.7 & 9.794 & 2.202 & 14.129 & 3.176 \\
\hline MA92-10 & MA9 & 25 & 127.6 & 75.3 & 8.915 & 2.004 & 13.055 & 2.935 \\
\hline MA94-11 & MA9 & 125 & 183.0 & 108.0 & 7.021 & 1.578 & 12.420 & 2.792 \\
\hline MA95-06 & MA9 & 290 & 186.7 & 110.2 & 5.312 & 1.194 & 10.341 & 2.325 \\
\hline VR1-09 & VR & -197 & 21.3 & 12.6 & 13.592 & 3.056 & 13.592 & 3.056 \\
\hline VR2-09 & VR & -120 & 34.9 & 20.6 & 12.772 & 2.871 & 14.637 & 3.291 \\
\hline VR1-10 & VR & -50 & 31.4 & 18.5 & 11.327 & 2.546 & 11.883 & 2.671 \\
\hline VR2-10 & VR & 0 & 73.7 & 43.5 & 11.044 & 2.483 & 14.582 & 3.278 \\
\hline VR1-11 & VR & 25 & 81.0 & 47.8 & 10.253 & 2.305 & 14.237 & 3.201 \\
\hline VR3-09 & VR & 25 & 64.0 & 37.8 & 10.653 & 2.395 & 13.084 & 2.941 \\
\hline VR2-11 & VR & 75 & 90.2 & 53.2 & 9.403 & 2.114 & 13.299 & 2.990 \\
\hline VR3-10 & VR & 175 & 126.6 & 74.7 & 7.382 & 1.660 & 12.674 & 2.849 \\
\hline VR3-11 & VR & 290 & 105.7 & 62.4 & 5.995 & 1.348 & 10.536 & 2.369 \\
\hline
\end{tabular}


Table A-2. Room-temperature Charpy-impact data for Shippingport cast stainless stee/s aged further in the laboratory

\begin{tabular}{|c|c|c|c|c|c|c|c|c|c|}
\hline \multirow{2}{*}{$\begin{array}{c}\text { Specimen } \\
\mathrm{ID}^{\mathrm{a}}\end{array}$} & \multirow{2}{*}{$\begin{array}{c}\text { Material } \\
I^{\mathrm{b}}\end{array}$} & \multicolumn{2}{|c|}{ Aging Condition } & \multicolumn{2}{|c|}{ Impact Energy } & \multicolumn{2}{|c|}{ Yield Load } & \multicolumn{2}{|c|}{ Maximum Load } \\
\hline & & Temp. $\left({ }^{\circ} \mathrm{C}\right)$ & Time $(\mathrm{h})$ & $\left(\mathrm{J} / \mathrm{cm}^{2}\right)$ & $(\mathrm{ft} \cdot \mathrm{lb})^{\mathrm{c}}$ & $(\mathrm{kN})$ & (kip) & $(\mathrm{kN})$ & (kip) \\
\hline CA41-10 & CA4 & Annealed & - & 196.1 & 115.7 & 8.593 & 1.932 & 14.373 & 3.231 \\
\hline CA42-12 & CA4 & Annealed & - & 179.8 & 106.1 & 9.149 & 2.057 & 14.705 & 3.306 \\
\hline CA41-02 & CA4 & Reactor Aged & - & 162.1 & 95.6 & 9.354 & 2.103 & 15.535 & 3.492 \\
\hline CA44-02 & CA4 & Reactor Aged & - & 128.5 & 75.8 & 9.589 & 2.156 & 14.881 & 3.345 \\
\hline CA41-04 & CA4 & 350 & 986 & 114.8 & 67.7 & 9.891 & 2.224 & 15.067 & 3.387 \\
\hline CA44-06 & CA4 & 350 & 986 & 166.4 & 98.2 & 10.253 & 2.305 & 15.379 & 3.457 \\
\hline CA41-07 & CA4 & 350 & 3000 & 96.2 & 56.8 & 9.618 & 2.162 & 14.285 & 3.211 \\
\hline CA42-07 & CA4 & 350 & 3000 & 120.8 & 71.3 & 9.227 & 2.074 & 14.188 & 3.190 \\
\hline CA41-08 & CA4 & 350 & 10000 & 83.1 & 49.0 & 9.755 & 2.193 & 14.159 & 3.183 \\
\hline CA42-08 & CA4 & 350 & 10000 & 115.7 & 68.3 & 9.569 & 2.151 & 15.897 & 3.574 \\
\hline CA43-09 & CA4 & 350 & 10000 & 90.3 & 53.3 & 9.188 & 2.065 & 13.309 & 2.992 \\
\hline CA41-09 & CA4 & 400 & 312 & 114.1 & 67.3 & 9.227 & 2.074 & 14.647 & 3.293 \\
\hline CA44-07 & CA4 & 400 & 312 & 102.3 & 60.4 & 8.876 & 1.995 & 13.905 & 3.126 \\
\hline CA41-06 & CA4 & 400 & 986 & 84.0 & 49.6 & 9.852 & 2.215 & 13.280 & 2.985 \\
\hline CA42-06 & CA4 & 400 & 986 & 128.1 & 75.6 & 9.833 & 2.211 & 15.223 & 3.422 \\
\hline CA41-05 & CA4 & 400 & 3000 & 61.9 & 36.5 & 10.302 & 2.316 & 12.840 & 2.887 \\
\hline CA42-05 & CA4 & 400 & 3000 & 103.2 & 60.9 & 9.755 & 2.193 & 14.481 & 3.255 \\
\hline CA42-04 & CA4 & 400 & 10000 & 82.8 & 48.9 & 9.589 & 2.156 & 13.905 & 3.126 \\
\hline CA43-06 & CA4 & 400 & 10000 & 80.2 & 47.3 & 9.804 & 2.204 & 13.485 & 3.031 \\
\hline CA44-04 & CA4 & 400 & 10000 & 65.3 & 38.5 & 9.774 & 2.197 & 12.616 & 2.836 \\
\hline CB7 & CB7 & Iged & - & 162.4 & 95.8 & 9.022 & 2.028 & 14 & 3.150 \\
\hline CB73-02 & CB7 & Reactor Aged & - & 203.7 & 120.2 & 8.700 & 1.956 & 14.666 & 3.297 \\
\hline CB71-07 & CB7 & 400 & 312 & 163.8 & 96.6 & 9.657 & 2.171 & 14.940 & 3.359 \\
\hline CB73-09 & CB7 & 400 & 312 & 263.9 & 155.7 & 8.798 & 1.978 & 14.988 & 3.369 \\
\hline CB71-08 & CB7 & 400 & 986 & 158.4 & 93.5 & 9.120 & 2.050 & 13.875 & 3.119 \\
\hline CB72-08 & CB7 & 400 & 986 & 186.4 & 110.0 & 9.159 & 2.059 & 14.159 & 3.183 \\
\hline CB71-09 & CA4 & 400 & 3000 & 189.1 & 111.6 & 9.628 & 2.164 & 13.963 & 3.139 \\
\hline CB72-09 & CA4 & 400 & 3000 & 191.4 & 112.9 & 9.520 & 2.140 & 13.534 & 3.043 \\
\hline MA11-08 & MA1 & Annealed & - & 62.2 & 36.7 & 10.194 & 2.292 & 11.522 & 2.590 \\
\hline MA11-06 & MA1 & Reactor Aged & - & 210.0 & 123.9 & 8.524 & 1.916 & 14.325 & 3.220 \\
\hline MA11-04 & MA1 & Reactor Aged & - & 144.5 & 85.3 & 10.106 & 2.272 & 14.207 & 3.194 \\
\hline MA11-18 & MA1 & 350 & 1052 & 68.1 & 40.2 & 9.364 & 2.105 & 11.610 & 2.610 \\
\hline MA11-17 & MA1 & 350 & 2987 & 159.2 & 93.9 & 9.403 & 2.114 & 14.256 & 3.205 \\
\hline MA11-16 & MA1 & 350 & 10000 & 160.4 & 94.6 & 9.716 & 2.184 & 14.539 & 3.268 \\
\hline MA11-19 & MA1 & 400 & 379 & 56.3 & 33.2 & 9.589 & 2.156 & 11.092 & 2.494 \\
\hline MA11-15 & MA1 & 400 & 1052 & 47.9 & 28.3 & 8.632 & 1.941 & 9.833 & 2.211 \\
\hline MA11-14 & MA1 & 400 & 2987 & 96.3 & 56.8 & 10.428 & 2.344 & 13.885 & 3.121 \\
\hline MA11-20 & MA1 & 400 & 2987 & 58.1 & 34.3 & 9.930 & 2.232 & 10.321 & 2.320 \\
\hline MA11-13 & MA1 & 400 & 10000 & 123.7 & 73.0 & 9.198 & 2.068 & 13.758 & 3.093 \\
\hline MA11-25 & MA1 & 400 & 10000 & 138.2 & 81.5 & 9.159 & 2.059 & 14.022 & 3.152 \\
\hline MA11-28 & MA1 & 400 & 10000 & 159.8 & 94.3 & 11.034 & 2.481 & 15.930 & 3.581 \\
\hline $\mathrm{MA}$ & N & & - & .1 & 157.6 & 76 & 1. & 13 & 3.095 \\
\hline MA12-06 & MA1 & Reactor Aged & - & 279.2 & 164.7 & 8.817 & 1.982 & 14.959 & 3.363 \\
\hline MA13-02 & MA1 & Reactor Aged & - & 337.6 & 199.2 & 9.237 & 2.077 & 15.877 & 3.569 \\
\hline MA13-05 & MA1 & Reactor Aged & - & 280.7 & 165.6 & 9.032 & 2.030 & 15.174 & 3.411 \\
\hline MA12-18 & MA1 & 350 & 1052 & 280.2 & 165.3 & 8.524 & 1.916 & 14.598 & 3.282 \\
\hline MA13-18 & MA1 & 350 & 1052 & 253.3 & 149.4 & 8.612 & 1.936 & 14.715 & 3.308 \\
\hline MA12-17 & MA1 & 350 & 2987 & 304.8 & 179.8 & 8.739 & 1.965 & 14.783 & 3.323 \\
\hline MA13-17 & MA1 & 350 & 2987 & 234.7 & 138.5 & 9.794 & 2.202 & 15.203 & 3.418 \\
\hline
\end{tabular}


Table A-2. (Contd.).

\begin{tabular}{|c|c|c|c|c|c|c|c|c|c|}
\hline \multirow{2}{*}{$\begin{array}{c}\text { Specimen } \\
\text { ID }^{\mathrm{a}}\end{array}$} & \multirow{2}{*}{$\begin{array}{c}\text { Material } \\
I D^{b}\end{array}$} & \multicolumn{2}{|c|}{ Aging Condition } & \multicolumn{2}{|c|}{ Impact Energy } & \multicolumn{2}{|c|}{ Yield Load } & \multicolumn{2}{|c|}{ Maximum Load } \\
\hline & & Temp. $\left({ }^{\circ} \mathrm{C}\right)$ & Time $(\mathrm{h})$ & $\left(\mathrm{J} / \mathrm{cm}^{2}\right)$ & $(\mathrm{ft} \cdot \mathrm{lb})^{\mathrm{c}}$ & $(k N)$ & $(k i p)$ & $(\mathrm{kN})$ & (kip) \\
\hline MA12-16 & MA1 & 350 & 10000 & 219.0 & 129.2 & 8.651 & 1.945 & 14.139 & 3.179 \\
\hline MA13-16 & MA1 & 350 & 10000 & & & & & & \\
\hline MA12-19 & MA1 & 400 & 379 & 263.4 & 155.4 & 8.437 & 1.897 & 14.852 & 3.339 \\
\hline MA12-15 & MA1 & 400 & 1052 & 236.8 & 139.7 & 8.007 & 1.800 & 14.012 & 3.150 \\
\hline MA13-15 & MA1 & 400 & 1052 & 236.4 & 139.5 & 8.417 & 1.892 & 14.998 & 3.372 \\
\hline MA12-14 & MA1 & 400 & 2987 & 193.3 & 114.0 & 9.481 & 2.131 & 14.334 & 3.222 \\
\hline MA12-20 & MA1 & 400 & 2987 & 230.3 & 135.9 & 10.253 & 2.305 & 15.545 & 3.495 \\
\hline MA13-14 & MA1 & 400 & 2987 & 216.0 & 127.4 & 9.911 & 2.228 & 15.682 & 3.525 \\
\hline MA12-13 & MA1 & 400 & 10000 & 194.6 & 114.8 & 8.769 & 1.971 & 14.676 & 3.299 \\
\hline MA13-13 & MA1 & 400 & 10000 & 117.1 & 69.1 & 10.145 & 2.281 & 13.700 & 3.080 \\
\hline MA12-25 & MA1 & 400 & 10000 & 164.2 & 96.9 & 9.120 & 2.050 & 14.246 & 3.203 \\
\hline MA12-26 & MA1 & 400 & 10000 & 189.4 & 111.7 & 8.642 & 1.943 & 13.983 & 3.144 \\
\hline MA12-27 & MA1 & 400 & 10000 & 239.2 & 141.1 & 8.856 & 1.991 & 15.067 & 3.387 \\
\hline MA12-28 & MA1 & 400 & 10000 & 211.0 & 124.5 & 8.612 & 1.936 & 14.862 & 3.341 \\
\hline MA13-22 & MA1 & 400 & 10000 & 142.5 & 84.1 & 9.276 & 2.085 & 14.520 & 3.264 \\
\hline MA13-23 & MA1 & 400 & 10000 & 183.5 & 108.3 & 8.905 & 2.002 & 15.067 & 3.387 \\
\hline MA13-24 & MA1 & 400 & 10000 & 205.8 & 121.4 & 8.974 & 2.017 & 15.281 & 3.435 \\
\hline MA & M & A & - & & 0 & 6 & 2. & 1 & 09 \\
\hline MA91-04 & MA9 & Reactor Aged & - & 350.2 & 206.6 & 8.515 & 1.914 & 15.233 & 3.425 \\
\hline MA93-04 & MA9 & Reactor Aged & - & 408.6 & 241.1 & 8.993 & 2.022 & 15.223 & 3.422 \\
\hline MA91-14 & MA9 & 320 & 2989 & 287.4 & 169.6 & 9.911 & 2.228 & 15.340 & 3.449 \\
\hline MA92-14 & MA9 & 320 & 2989 & 262.5 & 154.9 & 8.817 & 1.982 & 14.325 & 3.220 \\
\hline MA91-07 & MA9 & 320 & 10000 & 279.4 & 164.8 & 9.169 & 2.061 & 14.705 & 3.306 \\
\hline MA92-07 & MA9 & 320 & 10000 & 294.4 & 173.7 & 8.651 & 1.945 & 14.744 & 3.315 \\
\hline MA94-07 & MA9 & 320 & 29170 & 312.2 & 184.2 & 9.433 & 2.121 & 15.936 & 3.583 \\
\hline MA95-03 & MA9 & 320 & 29170 & 299.5 & 176.7 & 9.950 & 2.237 & 16.404 & 3.688 \\
\hline MA93-18 & MA9 & 350 & 311 & 334.1 & 197.1 & 8.788 & 1.976 & 14.403 & 3.238 \\
\hline MA94-18 & MA9 & 350 & 311 & 307.9 & 181.7 & 8.749 & 1.967 & 14.666 & 3.297 \\
\hline MA95-14 & MA9 & 350 & 311 & 416.7 & 245.9 & 8.993 & 2.022 & 15.028 & 3.378 \\
\hline MA91-18 & MA9 & 350 & 986 & 286.9 & 169.3 & 9.882 & 2.222 & 14.608 & 3.284 \\
\hline MA92-18 & MA9 & 350 & 986 & 319.0 & 188.2 & 8.954 & 2.013 & 13.953 & 3.137 \\
\hline MA91-13 & MA9 & 350 & 2987 & 242.3 & 143.0 & 9.442 & 2.123 & 14.491 & 3.258 \\
\hline MA92-12 & MA9 & 350 & 2987 & 258.3 & 152.4 & 9.003 & 2.024 & 14.139 & 3.179 \\
\hline MA92-13 & MA9 & 350 & 2987 & 324.7 & 191.6 & 9.061 & 2.037 & 14.998 & 3.372 \\
\hline MA91-09 & MA9 & 350 & 10000 & 151.7 & 89.5 & 9.999 & 2.248 & 15.399 & 3.462 \\
\hline MA94-08 & MA9 & 350 & 10000 & 198.2 & 116.9 & 8.964 & 2.015 & 14.569 & 3.275 \\
\hline MA91-17 & MA9 & 400 & 115 & 303.8 & 179.2 & 9.188 & 2.066 & 14.471 & 3.253 \\
\hline MA92-17 & MA9 & 400 & 115 & 390.2 & 230.2 & 8.192 & 1.842 & 14.442 & 3.247 \\
\hline MA93-15 & MA9 & 400 & 312 & 243.1 & 143.4 & 8.358 & 1.879 & 14.647 & 3.293 \\
\hline MA95-11 & MA9 & 400 & 312 & 222.8 & 131.5 & 9.188 & 2.066 & 14.471 & 3.253 \\
\hline MA91-16 & MA9 & 400 & 986 & 186.5 & 110.0 & 9.520 & 2.140 & 15.018 & 3.376 \\
\hline MA92-16 & MA9 & 400 & 986 & 199.7 & 117.8 & 9.354 & 2.103 & 14.315 & 3.218 \\
\hline MA93-14 & MA9 & 400 & 2987 & 205.4 & 121.2 & 9.423 & 2.118 & 14.832 & 3.334 \\
\hline MA94-14 & MA9 & 400 & 2987 & 158.4 & 93.5 & 9.462 & 2.127 & 14.393 & 3.236 \\
\hline MA95-10 & MA9 & 400 & 2987 & 159.8 & 94.3 & 10.458 & 2.351 & 14.080 & 3.165 \\
\hline MA92-10 & MA9 & 400 & 10000 & 127.6 & 75.3 & 8.915 & 2.004 & 13.055 & 2.935 \\
\hline VR1-01 & VR & Unaged & - & 200.0 & 118.0 & 12.479 & 2.805 & 16.766 & 3.769 \\
\hline VR3-01 & VR & Unaged & - & 274.2 & 161.8 & 10.839 & 2.437 & 16.395 & 3.686 \\
\hline VR $1-13$ & VR & 320 & 2989 & 223.9 & 132.1 & 11.434 & 2.570 & 15.916 & 3.578 \\
\hline VR2-13 & VR & 320 & 2989 & 271.9 & 160.4 & 10.477 & 2.355 & 16.746 & 3.765 \\
\hline
\end{tabular}


Table A-2. (Contd.).

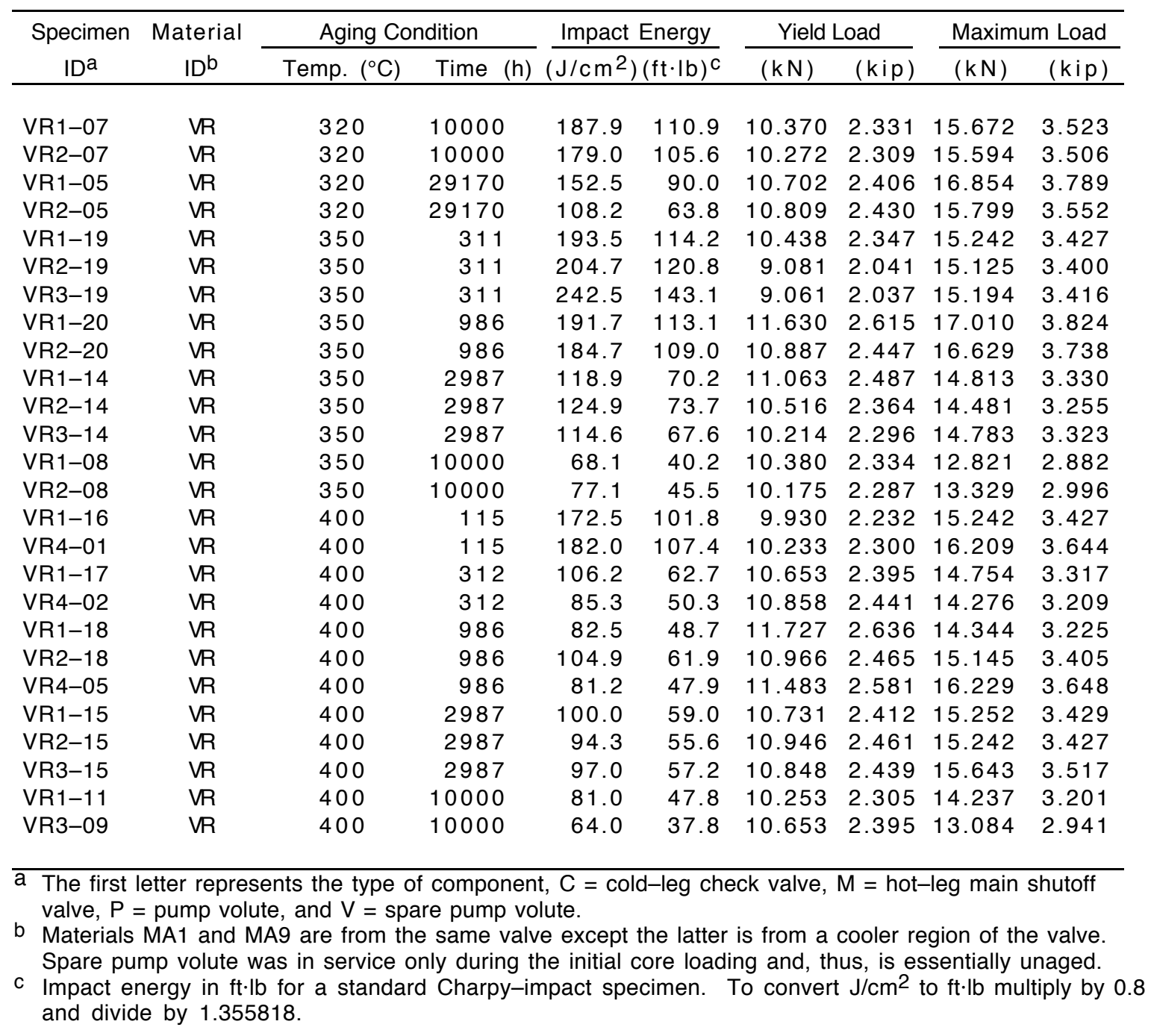




\section{Appendix B}

\section{Tensile Properties}

Tensile tests were performed at room temperature and at $290^{\circ} \mathrm{C}\left(554^{\circ} \mathrm{F}\right)$ according to ASTM Specification E 8 and E 21 in an Instron tensile test machine with a maximum loading capacity of $90 \mathrm{kN}$ (20 kips). Cylindrical specimens with a diameter of $5.08 \mathrm{~mm}(0.2 \mathrm{in}$.) and a gage length of $20.3 \mathrm{~mm}$ (0.8 in.), shown in Fig. B-1, were used for all of the tests. An axial extensometer, with an initial gage length of $20.3 \mathrm{~mm}$ (0.8 in.), was used for continuous measurement of strain during RT tests.

Tests at elevated temperatures were conducted in a forced-air recirculating furnace, with a clip gage mounted on the specimen grips. Total strain in the specimen gage length was determined from correlations developed from RT tests conducted with both clip gages attached to the specimen grips and the extensometer mounted on the specimen gage length. Thermocouples were mounted above and below the specimen gage length to monitor and control the temperature within $\pm 2^{\circ} \mathrm{C}$. An IBM computer was used to digitize load, crosshead movement, and axial displacement data, and store it on floppy disks. Analog traces of engineering stress-vs.-engineering stain were also obtained for each test. The true fracture stress was obtained from the fracture load and cross-sectional area at fracture. Tensile test data for the various materials are given in Table B-1.

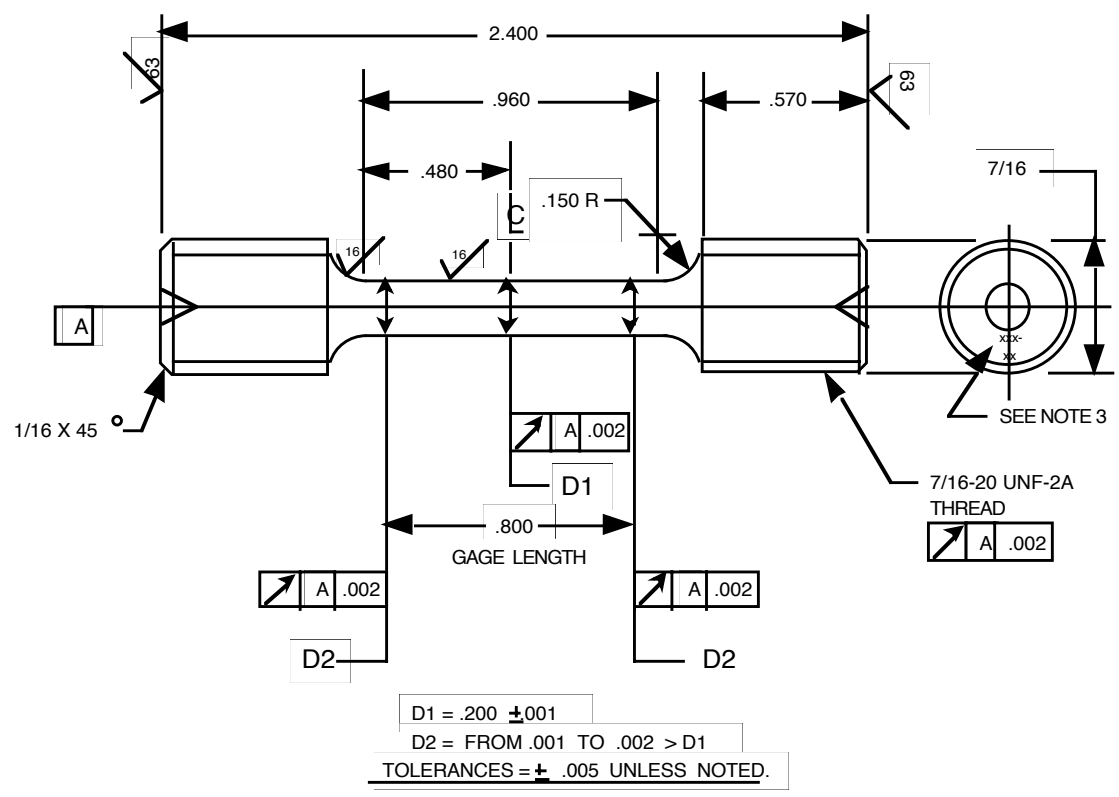

\footnotetext{
1. THE .800 INCH GAGE LENGTH TO HAVE UNIFORM SLOPE FROM MAX. DIA. D2 TO MIN. DIA. D1. UNIFORM SLOPE MUST NOT EXCEED .004 CHANGE IN DIA. PER 1 INCH CHANGE IN LENGTH.

2. ALL RADII MUST BLEND WITHOUT UNDERCUTS OR STEPS.

3. DIMENSIONS AND SPECIFICATIONS TYPICAL BOTH ENDS

4. ALL SURFACES TO BE FREE OF BURRS.
}

Figure B-1. Configuration of tensile test specimen: units of measure are inches 
Table B-1. Tensile test results for cast stainless stees from the Shippingport reactor

\begin{tabular}{|c|c|c|c|c|c|c|c|c|c|}
\hline \multirow{3}{*}{$\begin{array}{c}\text { Specimen } \\
\mathrm{ID}^{\mathrm{a}}\end{array}$} & \multirow{3}{*}{$\begin{array}{l}\text { Test } \\
\text { Temp. } \\
\left({ }^{\circ} \mathrm{C}\right) \\
\end{array}$} & \multicolumn{4}{|c|}{ Engineering Stress } & \multirow{2}{*}{\multicolumn{2}{|c|}{$\begin{array}{l}\text { True } \\
\text { Fracture Stress }\end{array}$}} & \multirow{3}{*}{$\begin{array}{c}\text { Elonga- } \\
\text { tion } \\
(\%)\end{array}$} & \multirow{3}{*}{$\begin{array}{c}\text { Red. ir } \\
\text { Area } \\
(\%)\end{array}$} \\
\hline & & \multicolumn{2}{|c|}{$0.2 \%$ Yield } & \multicolumn{2}{|c|}{ Ultimate } & & & & \\
\hline & & $(\mathrm{MPa})$ & $(\mathrm{ksi})$ & $(\mathrm{MPa})$ & $(\mathrm{ksi})$ & (MPa) & $(\mathrm{ksi})$ & & \\
\hline \multicolumn{10}{|c|}{ Cold Leg Check Valves ${ }^{b}$} \\
\hline CA41-T01 & 25 & 237.1 & 34.39 & 528.3 & 76.62 & 1268.7 & 184.01 & 63.5 & 66.0 \\
\hline CA41-T02 & 25 & 226.8 & 32.89 & 519.3 & 75.32 & 1404.0 & 203.63 & 57.9 & 73.7 \\
\hline CA42-T01 & 25 & 218.7 & 31.72 & 532.6 & 77.25 & 1466.0 & 212.63 & 60.3 & 68.6 \\
\hline CA41-T03 & 290 & 123.2 & 17.87 & 378.6 & 54.91 & 704.9 & 102.24 & 44.1 & 57.8 \\
\hline CA42-T02 & 290 & 132.2 & 19.17 & 370.2 & 53.69 & - & - & 32.7 & 35.5 \\
\hline CA42-T03 & 290 & 169.9 & 24.64 & 396.3 & 57.48 & 731.3 & 106.07 & 35.9 & 54.0 \\
\hline PV1-T01 & 25 & 230.1 & 33.37 & 523.6 & 75.94 & 1407.4 & 204.13 & 67.8 & 75.1 \\
\hline PV2-T01 & 25 & 226.4 & 32.84 & 510.1 & 73.98 & 1502.5 & 217.92 & 56.6 & 84.9 \\
\hline PV3-T01 & 25 & 233.8 & 33.91 & 497.7 & 72.19 & 1494.1 & 216.70 & 50.0 & 85.0 \\
\hline PV1-T02 & 290 & 143.3 & 20.78 & 345.6 & 50.13 & 678.4 & 98.39 & 29.1 & 62.1 \\
\hline PV2-T02 & 290 & 177.5 & 25.74 & 408.8 & 59.29 & 515.6 & 74.78 & 39.8 & 37.9 \\
\hline PV3-T02 & 290 & 151.4 & 21.96 & 368.6 & 53.46 & 961.5 & 139.45 & 46.6 & 69.2 \\
\hline \multicolumn{10}{|c|}{ Hot Leg Main Shutoff Valves ${ }^{\mathrm{c}}$} \\
\hline MA11-T01 & 25 & 226.8 & 32.89 & 490.9 & 71.20 & 1659.4 & 240.68 & 40.2 & 82.0 \\
\hline MA11-T02 & 25 & 252.3 & 36.59 & 429.6 & 62.31 & - & - & 22.8 & 30.9 \\
\hline MA12-T01 & 25 & 212.6 & 30.84 & 486.0 & 70.49 & 1374.7 & 199.38 & 27.4 & 73.6 \\
\hline MA11-T03 & 290 & - & - & 275.9 & 40.02 & - & - & 10.2 & 13.3 \\
\hline MA12-T02 & 290 & 129.6 & 18.80 & 330.9 & 47.99 & 520.0 & 75.42 & 32.6 & 47.6 \\
\hline MA12-T03 & 290 & 134.6 & 19.52 & 353.0 & 51.20 & 701.4 & 101.73 & 31.2 & 64.3 \\
\hline \multicolumn{10}{|l|}{ Unagedd } \\
\hline MA91-T01 & 25 & 221.1 & 32.07 & 479.9 & 69.60 & 1154.7 & 167.48 & 67.1 & 77.2 \\
\hline MA93-T01 & 25 & 237.5 & 34.45 & 500.8 & 72.63 & 1468.2 & 212.94 & 65.0 & 79.1 \\
\hline MA94-T01 & 290 & 161.3 & 23.39 & 410.4 & 59.52 & 646.8 & 93.81 & 37.5 & 46.1 \\
\hline MA92-T01 & 290 & 158.5 & 22.99 & 308.6 & 44.76 & - & - & 24.6 & 41.7 \\
\hline VR1-T01 & 25 & 276.8 & 40.15 & 525.2 & 76.17 & 1182.1 & 171.45 & 42.9 & 75.8 \\
\hline VR2-T01 & 25 & 269.1 & 39.03 & 548.7 & 79.58 & 822.5 & 119.29 & 65.3 & 58.8 \\
\hline VR1-T02 & 290 & 166.3 & 24.12 & 388.8 & 56.39 & 630.5 & 91.45 & 32.1 & 51.1 \\
\hline VR3-T01 & 290 & 151.7 & 22.00 & 359.1 & 52.08 & 521.0 & 75.56 & 32.9 & 44.9 \\
\hline \multicolumn{10}{|c|}{ Aged $10,000 \mathrm{~h}$ at $400^{\circ} \mathrm{C}$} \\
\hline MA92-T09 & 25 & 251.6 & 36.49 & 520.9 & 75.55 & 930.5 & 134.96 & 25.3 & 58.1 \\
\hline MA93-T09 & 25 & 221.1 & 32.07 & 495.0 & 71.79 & 1487.8 & 215.79 & 39.8 & 73.7 \\
\hline MA92-T11 & 290 & 148.2 & 21.49 & 367.9 & 53.36 & 603.0 & 87.46 & 37.0 & 50.6 \\
\hline MA93-T11 & 290 & 140.0 & 20.31 & 382.4 & 55.46 & 604.3 & 87.65 & 35.3 & 47.7 \\
\hline VR1-T03 & 25 & - & 51.42 & 678.0 & 98.34 & 1249.4 & 181.21 & 18.0 & 50.3 \\
\hline VR2-T03 & 25 & 276.9 & 40.16 & 611.6 & 88.71 & 813.4 & 117.97 & 45.0 & 44.0 \\
\hline VR3-T03 & 25 & 271.7 & 39.41 & 590.7 & 85.67 & 1238.2 & 179.59 & 36.4 & 57.7 \\
\hline VR2-T02 & 290 & 186.6 & 27.06 & 409.2 & 59.35 & 348.1 & 50.49 & 18.6 & 31.0 \\
\hline VR3-T02 & 290 & 182.8 & 26.51 & 441.8 & 64.08 & 604.4 & 87.66 & 26.2 & 35.1 \\
\hline
\end{tabular}

a First two letters represent the material identification.

b In service for $\approx 13$ y at $264^{\circ} \mathrm{C}$.

C In service for $\approx 13$ y at $281^{\circ} \mathrm{C}$.

d Material from cooler region of the component or essentially unaged. 


\section{Appendix C}

\section{J-R Curve Characterization}

The J-R curve tests were performed according to ASTM Specifications E 813-85 (Standard Test Method for $\mathrm{J}_{\mathrm{IC}}$, a Measure of Fracture Toughness) and E 1152-87 (Standard Test Method for Determining J-R Curve). Compact-tension (CT) specimens, $25.4 \mathrm{~mm}$ (1 in.) thick with $10 \%$ side grooves, were used for the tests. The CT specimen design, shown in Fig. C-1, is similar to the specimen of ASTM Specification E 399, the notch region is modified in accordance with E 813 and E 5112, to permit measurement of load-line displacement by axial extensometer. The extensometer was mounted on razor blades that were screwed onto the specimen along the load line.

Prior to testing, the specimens were fatigue-precracked at room temperature and at load levels within the linear elastic range. The final ratio of crack length to width (a/W) after pre-

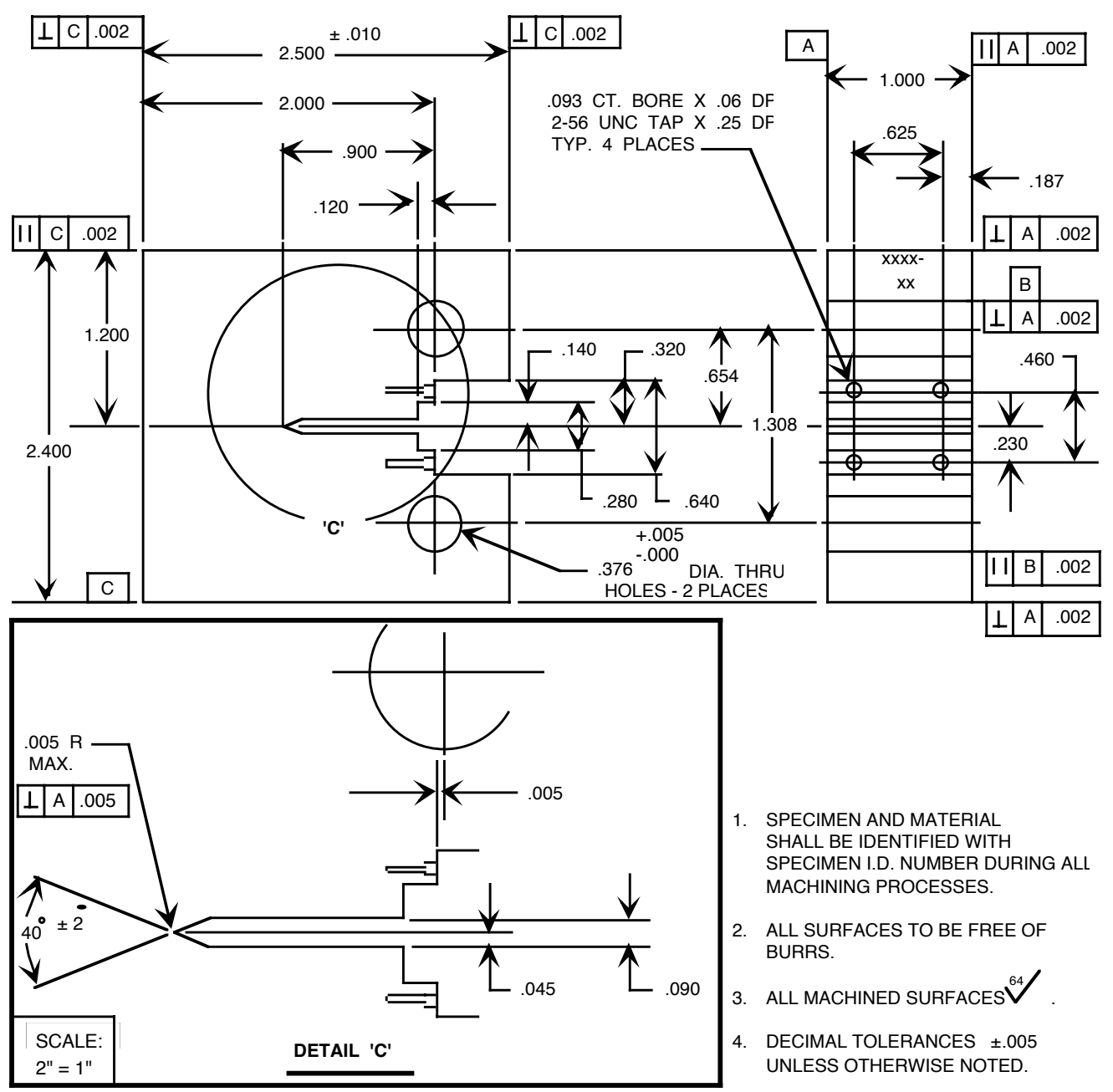

Figure C-1. Configuration of compact-tension test specimen: units of measure are inches 
cracking was $\approx 0.55$. The final $1-\mathrm{mm}(\approx 0.04-$ in. $)$ crack extension was carried out at a load range of $13-1.3 \mathrm{kN}$ (2.92-0.292 kip), i.e., during precracking $\mathrm{K}_{\max }$ was $<25 \mathrm{MPa} \cdot \mathrm{m}^{1 / 2}(22.6$ $\mathrm{ksi} \cdot \mathrm{in} .{ }^{1 / 2}$ ). After precracking, all specimens were side-grooved by $20 \%$ of the total specimen thickness, i.e., $10 \%$ per side, to ensure uniform crack growth during testing.

The J-R curve tests were performed on an Instron testing machine with $90 \mathrm{kN}$ (20 kip) maximum load capacity. The load and load-line displacement data were digitized with digital voltmeters and stored on a disk for posttest analysis and correction of test data. The single-specimen compliance procedure was used to estimate crack extension. Rotation and modulus corrections were applied to the compliance data. Both deformation theory and modified forms of the $\mathrm{J}$ integral were evaluated for each test.

After each test, the specimen was heated to $350^{\circ} \mathrm{C}$ to heat-tint the exposed fracture surface. The specimen was then fractured at liquid $\mathrm{N}$ temperature. The initial (i.e., fatigue precrack) and final (test) crack lengths were measured optically for both halves of the fractured specimen. The crack lengths were determined by the $9 / 8$ averaging technique, i.e., the two near-surface measurements were averaged and the resultant value was averaged with the remaining seven measurements.

The fracture toughness $J_{I C}$ values were determined in accordance with ASTM Specification $E$ 813-81 and $E$ 813-85. For the former, $J_{I C}$ is defined as the intersection of the blunting line given by $\mathrm{J}=2 \sigma_{f} \Delta \mathrm{a}$, and the linear fit of the $\mathrm{J}-\mathrm{vs} .-\Delta \mathrm{a}$ test data between the $0.15-$ and $1.5-\mathrm{mm}$ exclusion lines. The flow stress $\sigma_{f}$, is the average of the $0.2 \%$ yield stress and the ultimate stress. The ASTM Specification E 813-85 procedure defines $J_{I C}$ as the intersection of the 0.2-mm offset line with the power-law fit (of the form $\mathrm{J}=\mathrm{C} \Delta \mathrm{a}^{\mathrm{n}}$ ) of the test data between the exclusion lines. J-R curve tests on cast stainless steels indicate that a slope of four times the flow stress $\left(4 \sigma_{f}\right)$ for the blunting line expresses the J-vs. $-\Delta$ a data better than the slope of $2 \sigma_{f}$ defined in E 813-81 or E 813-85. The fracture toughness $J_{I C}$ values were determined with the $4 \sigma_{f}$ slope.

The tearing modulus was also evaluated for each test. The tearing modulus is given by $T=$ $E(d J / d a) / \sigma_{f}{ }^{2}$, where $E$ is the Young's modulus and $\sigma_{f}$ is the flow stress. The ASTM E 813-81 value of tearing modulus is determined from the slope $\mathrm{dJ} / \mathrm{da}$ of the linear fit to the J-vs. $-\Delta a$ data. For the power-law curve fits, an average value of $\mathrm{dJ} / \mathrm{da}$ was calculated $\mathrm{C}^{-1}$ to obtain the average tearing modulus.

The fracture toughness results at room temperature and $290^{\circ} \mathrm{C}$ for service-aged material from the cold-leg check valve CA4, hot-leg main shutoff valve MA1, and pump volute PV, and relatively unaged material from the spare pump volute $V R$ and cooler regions of the main shutoff valve MA9, are given in Table $\mathrm{C}-1$. The test data, as well as an analysis and qualification of the data, are presented in Tables C-2 to C-61. Photographs of the fracture surface of the test specimens and deformation and modified $\mathrm{J}-\mathrm{R}$ curves for the various materials are shown in Figs. C-2 to C-61. The blunting, 0.2- $\mathrm{mm}$ offset, and 1.5- $\mathrm{mm}$ offset lines are shown as dashed lines in the figures.

\section{Data Analysis Procedures}

The compliance method was used to determine the crack length during the tests. The Hudak-Saxena calibration equation $\mathrm{C}^{-2}$ was used to relate the specimen load-line elastic com- 
pliance $C_{i}$ on an unloading/loading sequence with the crack length $a_{i}$. The compliance, i.e., slope $(\Delta \delta / \Delta \mathrm{P})$ of the load-line displacement-vs.-load record obtained during the unloading/loading sequence, is given by

$$
\mathrm{U}_{\mathrm{LL}}=\frac{1}{\left(\mathrm{~B}_{\mathrm{e}} \mathrm{E}_{\mathrm{e}} \mathrm{C}_{\mathrm{i}}\right)^{1 / 2}+1}
$$

and

$$
\begin{aligned}
\mathrm{a}_{\mathrm{i}} / \mathrm{W}= & 1.000196-4.06319\left(\mathrm{U}_{\mathrm{LL}}\right)+11.242\left(\mathrm{U}_{\mathrm{LL}}\right)^{2}-106.043\left(\mathrm{U}_{\mathrm{LL}}\right)^{3} \\
& +464.335\left(\mathrm{U}_{\mathrm{LL}}\right)^{4}-650.677\left(\mathrm{U}_{\mathrm{LL}}\right)^{5},
\end{aligned}
$$

where $E_{e}$ is the effective elastic modulus, $B_{e}$ is the effective specimen thickness expressed as $B$ $-\left(B-B_{N}\right)^{2} / B$, and $W$ is specimen width.

Both rotation and modulus corrections are applied to the compliance data. The modulus correction $\mathrm{C}^{-2}$ is used to account for the uncertainties in testing, i.e., in the values of initial crack length determined by compliance and measured optically. The effective modulus $E_{M}$ is determined from

$$
E_{e}=\frac{1}{C_{o} B_{e}}\left(\frac{W+a_{o}}{W-a_{o}}\right)^{1 / 2} f\left(\frac{a_{o}}{W}\right)
$$

and

$$
\begin{aligned}
f\left(\frac{a_{o}}{W}\right)= & 2.163+12.219\left(\frac{a_{o}}{W}\right)-20.065\left(\frac{a_{o}}{W}\right)^{2}-0.9925\left(\frac{a_{o}}{W}\right)^{3} \\
& +20.609\left(\frac{a_{o}}{W}\right)^{4}-9.9314\left(\frac{a_{o}}{W}\right)^{5}
\end{aligned}
$$

where $C_{0}$ is initial compliance, $B_{e}$ is effective specimen thickness, and $a_{0}$ is the initial physical crack size measured optically.

To account for crack-opening displacement in CT specimens, the crack size should be corrected for rotation. $\mathrm{C}-3$ The corrected compliance is calculated from

$$
\theta=\operatorname{Sin}^{-1}\left[\left(\frac{\mathrm{d}_{\mathrm{m}}}{2}+\mathrm{D}\right) /\left(\mathrm{D}^{2}+\mathrm{R}^{2}\right)^{1 / 2}\right]-\tan ^{-1}\left(\frac{\mathrm{D}}{\mathrm{R}}\right)
$$

and

$$
\mathrm{C}_{\mathrm{c}}=\mathrm{C}_{\mathrm{m}} /\left[\left(\frac{\mathrm{H}^{*}}{\mathrm{R}} \operatorname{Sin} \theta-\operatorname{Cos} \theta\right)\left(\frac{\mathrm{D}}{\mathrm{R}} \operatorname{Sin} \theta-\operatorname{Cos} \theta\right)\right],
$$

where $\mathrm{C}_{c}$ and $\mathrm{C}_{m}$ are the corrected and measured elastic compliance at the load line, $\mathrm{H}^{*}$ is the initial half span of load points, $R$ is the radius of rotation of the crack centerline $(=(W+a) / 2)$, a is the updated crack length, $D$ is one-half of the initial distance between the displacement points (i.e., half gage length), $d_{m}$ is the total measured load-line displacement, and $\theta$ is the angle of rotation of a rigid-body element about the unbroken midsection line. 
The $\mathrm{J}$ value is calculated at any point on the load-vs.-load-line displacement record by means of the relationship

$$
\mathbf{J}=\mathbf{J}_{\mathrm{el}}+\mathbf{J}_{\mathrm{pl}},
$$

where $J_{e l}$ is the elastic component of $J$ and $J_{p l}$ is the plastic component of $J$. For a CT specimen, at a point corresponding to the coordinates $\mathrm{P}_{\mathrm{i}}$ and $\delta_{\mathrm{i}}$ on the specimen load-vs.-load-line displacement record, $a_{i}$ is $\left(a_{0}+\Delta a_{i}\right)$, and the deformation $\mathrm{J}$ is given by

$$
\mathbf{J}_{\mathrm{d}(\mathrm{i})}=\frac{\left(\mathrm{K}_{\mathrm{i}}\right)^{2}\left(1-v^{2}\right)}{\mathrm{E}_{\mathrm{e}}}+\mathbf{J}_{\mathrm{pl}(\mathrm{i})},
$$

where, from ASTM method E 399,

$$
\mathrm{K}_{(\mathrm{i})}=\left[\frac{\mathrm{P}_{\mathrm{i}}}{\left(\mathrm{BB}_{\mathrm{N}} \mathrm{W}_{\mathrm{e}}\right)^{1 / 2}}\right] \mathrm{f}\left(\frac{\mathrm{a}_{\mathrm{i}}}{\mathrm{W}}\right),
$$

with

$$
\begin{aligned}
\mathrm{f}\left(\frac{\mathrm{a}_{\mathrm{i}}}{\mathrm{W}}\right)=\left[2+\left(\frac{\mathrm{a}_{\mathrm{i}}}{\mathrm{W}}\right)\right][ & 0.886+4.64\left(\frac{\mathrm{a}_{\mathrm{i}}}{\mathrm{W}}\right)-13.32\left(\frac{\mathrm{a}_{\mathrm{i}}}{\mathrm{W}}\right)^{2}+14.72\left(\frac{\mathrm{a}_{\mathrm{i}}}{\mathrm{W}}\right)^{3} \\
& \left.-5.6\left(\frac{\mathrm{a}_{\mathrm{i}}}{\mathrm{W}}\right)^{4}\right] /\left[1-\left(\frac{\mathrm{a}_{\mathrm{i}}}{\mathrm{W}}\right)\right]^{3 / 2}
\end{aligned}
$$

and

$$
\mathbf{J}_{\mathrm{pl}(\mathrm{i})}=\left[\mathbf{J}_{\mathrm{pl}(\mathrm{i}-1)}+\left(\frac{\eta_{\mathrm{i}}}{\mathrm{b}_{\mathrm{i}}}\right) \frac{\mathrm{A}_{\mathrm{pl}(\mathrm{i})}-\mathrm{A}_{\mathrm{pl}(\mathrm{i}-1)}}{\mathrm{B}_{\mathrm{N}}}\right]\left[1-\left(\frac{\gamma_{\mathrm{i}}}{\mathrm{b}_{\mathrm{i}}}\right)\left(\mathrm{a}_{\mathrm{i}}-\mathrm{a}_{\mathrm{i}-1}\right)\right],
$$

where $v$ is Poisson's ratio, $b$ is the uncracked ligament, $A_{p l}$ is the plastic component of the area under the load-vs.-load-line displacement record, and $\eta \imath \sigma$ a factor that accounts for the tensile component of the load as given by

$$
\eta_{\mathrm{i}}=2+0.522 \mathrm{~b}_{\mathrm{i}} / \mathrm{W},
$$

and $\gamma$, a factor that accounts for limited crack growth as given by

$$
\gamma_{\mathrm{i}}=1+0.76 \mathrm{~b}_{\mathrm{i}} / \mathrm{W} .
$$

The modified $\mathrm{J}$ values $\left(\mathrm{J}_{\mathrm{M}}\right)$ are calculated from the relationship (from Ref. C-4)

$$
\mathbf{J}_{\mathrm{M}(\mathrm{i})}=\mathbf{J}_{\mathrm{d}(\mathrm{i})}+\Delta \mathbf{J}_{\mathrm{i}},
$$

where

$$
\Delta \mathbf{J}_{\mathrm{i}}=\Delta \mathbf{J}_{\mathrm{i}-1}+\left(\frac{\gamma_{\mathrm{i}}}{\mathbf{b}_{\mathrm{i}}}\right) \mathbf{J}_{\mathrm{pl}(\mathrm{i})}\left(\mathrm{a}_{\mathrm{i}}-\mathbf{a}_{\mathrm{i}-1}\right) .
$$

According to ASTM Specification E 1152-87, the $J_{D}-R$ curves are valid only for crack growth up to $10 \%$ of the initial uncracked ligament. Also, they show a dependence on specimen size. The 
$J_{M}-R$ curves have been demonstrated to be independent of specimen size and yield valid results for larger crack growth.

\section{Data Qualification}

The various validity criteria specified in ASTM Specification E 813-85 for JIC and in ASTM Specification E 1152-87 for J-R curves, were used to qualify the results from each test. The various criteria include maximum values of crack extension and $\mathrm{J}$-integrals; limits for initial uncracked ligaments, effective elastic modulus, and optically measured physical crack lengths; and spacing of $\mathrm{J}-\Delta$ a data points. The $\omega$ criterion (from Ref. $\mathrm{C}-5$ ) was also used to ensure that a region of $\mathrm{J}$ dominance exists.

For the present investigation, most of the unaged or service-aged specimens yielded invalid $J_{I C}$ values because of the relatively high toughness of the material. The reasons for the discrepancies are data-point spacing, shape of the final crack front, or size of the uncracked ligament. In general, the size of the uncracked ligament or the specimen thickness was inadequate because of the relatively high toughness of the material. The $J_{\max }$ limit for the $\mathrm{J}-\mathrm{vs} .-\Delta \mathrm{a}$ data was ignored in most tests to obtain a good power-law fit of the test data.

All tests showed significant load relaxation during the unloading/reloading cycle for estimating the crack length by elastic compliance. All unloadings were $25 \%$ of the load. The load at the end of the unloading/reloading cycle was always lower than it was at the start of the unloading cycle. The difference was appreciable for the RT tests. Therefore, the initial $20-30 \%$ of the unloading curve was ignored in estimating crack length.

\section{References}

C-1. A. L. Hiser, F. J. Loss, and B. H. Menke, J-R Curve Characterization of Irradiated Low Upper Shelf Welds, NUREG/CR-3506, MEA-2028, Materials Engineering Associates, Inc., Lanham, MD (April 1984).

C-2. A. Saxena and S. J. Hudak, Jr., "Review and Extention of Compliance Information for Common Crack Growth Specimen," Int. J. Fracture, 5, Vol. 14, 453-468 (1978).

C-3. F. J. Loss, B. H. Menke, and R. A. Gray, Jr., "Development of J-R Curve Procedures," in NRL-EPRI Research Program (RP 886-2), Evaluation and Prediction of Neutron Embrittlement in Reactor Pressure Vessel Materials Annual Progress Report for FY 1978, J. R. Hawthorn, ed., NRL Report 8327, Naval Research Laboratory, Annapolis, MD (August 1979).

C-4. H. A. Ernst, "Material Resistance and Instability Beyond J-Controlled Crack Growth," Elastic-Plastic Fracture: Second Sym., Vol. I: Inelastic Crack Analysis, ASTM STP 803, American Society for Testing and Materials, Philadelphia (1983).

C-5. J. W. Hutchinson and P. C. Paris, "The Theory of Stability Analysis of J-Controlled Crack Growth," Elastic Plastic Fracture, ASTM STP 668, American Society for Testing and Materials, Philadelphia, pp. 37-64 (1983). 


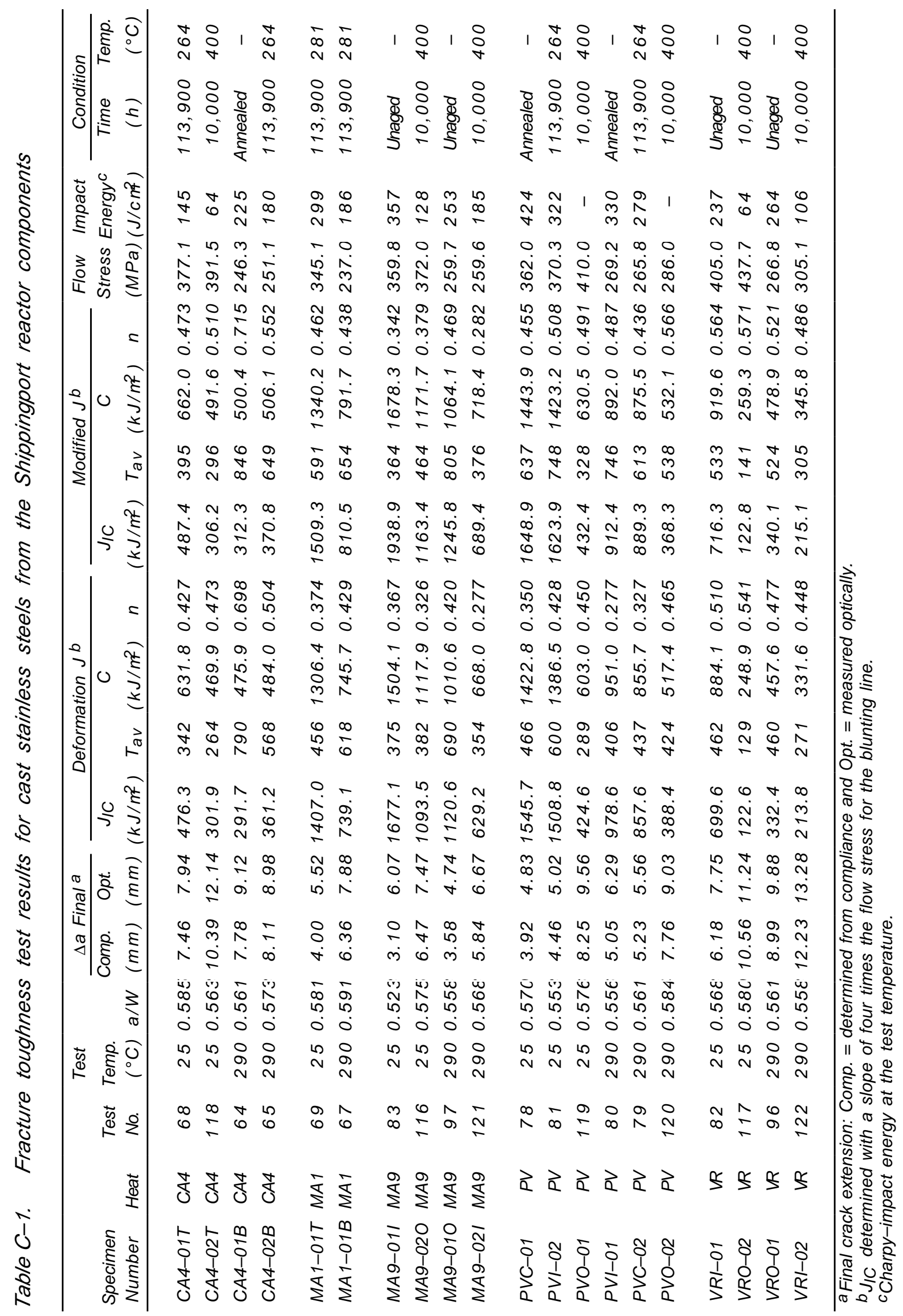


Table C-2. Test data for specimen CA4-01T

\begin{tabular}{|c|c|c|c|c|c|}
\hline \multicolumn{2}{|c|}{$\begin{array}{l}\text { Test Number } \\
\text { Material Type } \\
\text { Aging Temp. } \\
\text { Spec. Thickness } \\
\text { Spec. Width }\end{array}$} & $\begin{array}{l}0068 \\
: C F-8 \\
: 264^{\circ} \mathrm{C} \\
25.35 \mathrm{~mm} \\
50.82 \mathrm{~mm}\end{array}$ & \multicolumn{2}{|c|}{$\begin{array}{l}\text { Test Temp. } \\
\text { Heat Number } \\
\text { Aging Time } \\
\text { Net Thickness } \\
\text { Flow Stress }\end{array}$} & $\begin{array}{l}: 25^{\circ} \mathrm{C} \\
: \mathrm{CA} \\
: 113,900 \mathrm{~h} \\
: 20.34 \mathrm{~mm} \\
: 377.10 \mathrm{MPa}\end{array}$ \\
\hline $\begin{array}{c}\text { Unload } \\
\text { Number }\end{array}$ & $\begin{array}{c}J_{d} \\
\left(k J / m^{2}\right)\end{array}$ & $\begin{array}{c}J_{m} \\
\left(k J / m^{2}\right)\end{array}$ & $\begin{array}{c}\Delta a \\
(\mathrm{~m} \mathrm{~m})\end{array}$ & $\begin{array}{l}\text { Load } \\
(\mathrm{kN})\end{array}$ & $\begin{array}{c}\text { Deflection } \\
(\mathrm{m} \mathrm{m})\end{array}$ \\
\hline 1 & 11.57 & 11.61 & 0.1818 & 17.005 & 0.225 \\
\hline 2 & 25.72 & 25.70 & 0.1164 & 20.151 & 0.376 \\
\hline 3 & 42.36 & 42.53 & 0.2230 & 21.725 & 0.526 \\
\hline 4 & 63.25 & 63.22 & 0.1595 & 22.992 & 0.708 \\
\hline 5 & 88.31 & 87.80 & 0.0505 & 24.043 & 0.910 \\
\hline 6 & 114.75 & 114.49 & 0.0914 & 24.859 & 1.115 \\
\hline 7 & 147.16 & 146.23 & 0.0078 & 25.658 & 1.360 \\
\hline 8 & 180.85 & 180.93 & 0.1083 & 26.322 & 1.610 \\
\hline 9 & 215.68 & 215.26 & 0.0667 & 27.047 & 1.860 \\
\hline 10 & 251.41 & 252.09 & 0.1440 & 27.680 & 2.114 \\
\hline 11 & 285.83 & 288.39 & 0.2580 & 28.212 & 2.361 \\
\hline 12 & 321.41 & 325.33 & 0.3304 & 28.698 & 2.610 \\
\hline 13 & 359.53 & 363.24 & 0.3203 & 29.035 & 2.861 \\
\hline 14 & 396.49 & 402.78 & 0.4305 & 29.381 & $\begin{array}{l}3.112 \\
3.11\end{array}$ \\
\hline 15 & 434.71 & 441.37 & 0.4449 & 29.892 & 3.361 \\
\hline 16 & 472.62 & 481.47 & 0.5224 & 30.197 & 3.610 \\
\hline 17 & 511.96 & 522.14 & 0.5655 & 30.593 & 3.863 \\
\hline 18 & 551.50 & 563.82 & 0.6300 & 30.734 & 4.117 \\
\hline 19 & 588.38 & 605.10 & 0.7528 & 30.762 & 4.366 \\
\hline 20 & 626.24 & 644.92 & 0.8042 & 30.766 & 4.609 \\
\hline 21 & 661.23 & $\begin{array}{l}690.99 \\
690\end{array}$ & $\begin{array}{l}1.0754 \\
1.075\end{array}$ & 30.709 & 4.879 \\
\hline 22 & 689.96 & 728.52 & $\begin{array}{l}1.2798 \\
\text {. }\end{array}$ & 30.486 & 5.109 \\
\hline 23 & 724.47 & 770.15 & 1.4362 & 30.247 & 5.360 \\
\hline 24 & 755.21 & 812.21 & 1.6725 & 30.278 & 5.609 \\
\hline 25 & 790.56 & 853.49 & $\begin{array}{l}1.01200 \\
1.7900\end{array}$ & 30.251 & 5.859 \\
\hline 26 & 825.10 & 896.29 & 1.9458 & 30.198 & 6.110 \\
\hline 27 & 864.69 & 938.04 & 1.9845 & 30.318 & 6.359 \\
\hline 28 & 898.54 & 983.65 & 2.1855 & 29.997 & 6.618 \\
\hline 29 & 930.48 & 1025.20 & 2.3431 & 29.926 & 6.864 \\
\hline 30 & 968.85 & 1068.14 & 2.4147 & 29.891 & 7.117 \\
\hline 31 & 1005.35 & 1110.42 & 2.5017 & 29.852 & 7.361 \\
\hline 32 & 1047.91 & 1162.83 & 2.6430 & 29.947 & 7.660 \\
\hline 33 & 1087.29 & 1215.67 & 2.8272 & 29.816 & 7.961 \\
\hline 34 & 1128.79 & 1267.78 & $\begin{array}{l}2.9664 \\
\end{array}$ & 29.710 & 8.261 \\
\hline 35 & 1168.16 & 1321.31 & 3.1442 & 29.350 & 8.564 \\
\hline $\begin{array}{l}30 \\
36\end{array}$ & 1223.55 & 1400.79 & $\begin{array}{l}0.1442 \\
3.4291\end{array}$ & 28.998 & $\begin{array}{l}0.011 \\
9.011\end{array}$ \\
\hline 37 & 1280.04 & 1469.89 & 3.5707 & 28.841 & 9.412 \\
\hline 38 & 1345.43 & 1559.06 & 3.8215 & 28.325 & 9.912 \\
\hline 39 & 1399.58 & 1647.93 & 4.1677 & 28.008 & 10.414 \\
\hline 40 & 1469.38 & 1752.88 & 4.4962 & 27.516 & 11.012 \\
\hline 41 & 1534.86 & 1858.68 & 4.8504 & 26.742 & 11.612 \\
\hline 42 & 1587.69 & 1963.10 & 5.2789 & 25.823 & 12.214 \\
\hline 43 & 1644.41 & 2064.12 & 5.6274 & 24.956 & 12.812 \\
\hline 44 & 1708.70 & 2165.24 & 5.9021 & 24.432 & 13.413 \\
\hline 45 & 1746.72 & 2266.44 & 6.3516 & 23.345 & 14.010 \\
\hline 46 & 1778.46 & 2363.29 & 6.7955 & 22.583 & 14.606 \\
\hline 47 & 1826.17 & 2460.15 & 7.1156 & 21.905 & 15.209 \\
\hline $\begin{array}{l}47 \\
48\end{array}$ & 1866.97 & 2556.83 & 7.4643 & 21.336 & 15.803 \\
\hline
\end{tabular}


Table C-3. Deformation JIC and J-R curve results for specimen CA4-01T

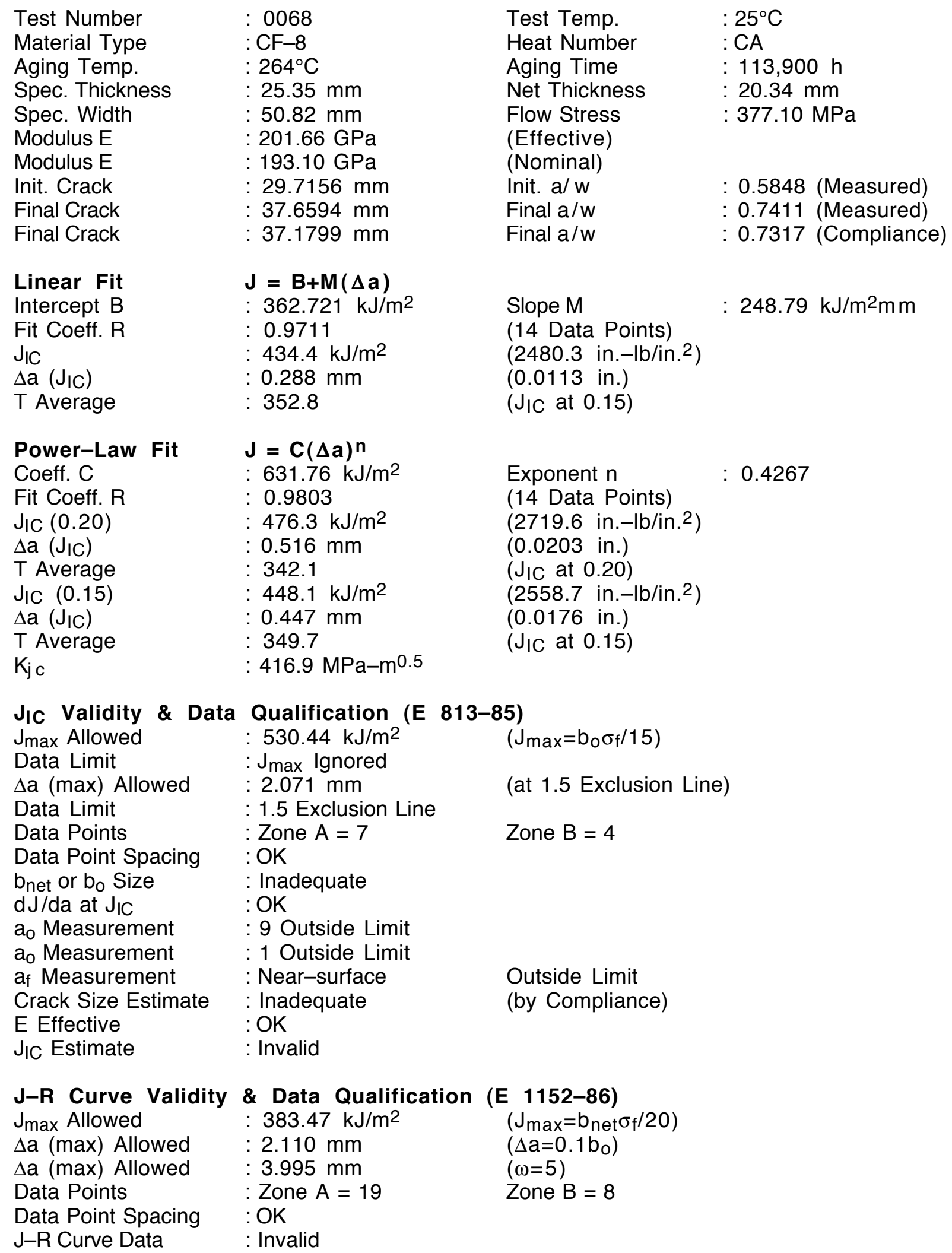


Table C-4. Modified J/C and J-R curve results for specimen CA4-01T

\begin{tabular}{|c|c|c|c|}
\hline $\begin{array}{l}\text { Linear Fit } \\
\text { Intercept B } \\
\text { Fit Coeff. R } \\
\mathrm{J}_{\mathrm{IC}} \\
\Delta \mathrm{a}\left(\mathrm{J}_{\mathrm{IC}}\right) \\
\mathrm{T} \text { Average }\end{array}$ & $\begin{array}{l}\mathbf{J}=\mathbf{B}+\mathbf{M}(\Delta \mathbf{a}) \\
: 348.207 \mathrm{~kJ} / \mathrm{m}^{2} \\
: 0.9800 \\
: 431.8 \mathrm{~kJ} / \mathrm{m}^{2} \\
: 0.286 \mathrm{~mm} \\
: 414.0\end{array}$ & $\begin{array}{l}\text { Slope } M \\
(14 \text { Data Points) } \\
\left(2465.5 \text { in.-lb/in. }{ }^{2}\right) \\
(0.0113 \text { in. }) \\
\left(J_{I C} \text { at } 0.15\right)\end{array}$ & : $291.92 \mathrm{~kJ} / \mathrm{m}^{2} \mathrm{~mm}$ \\
\hline $\begin{array}{l}\text { Power-Law Fit } \\
\text { Coeff. C } \\
\text { Fit Coeff. R } \\
\mathrm{J}_{\mathrm{IC}}(0.20) \\
\Delta \mathrm{a}\left(\mathrm{J}_{\mathrm{IC}}\right) \\
\text { T Average } \\
\mathrm{J}_{\mathrm{IC}}(0.15) \\
\Delta \mathrm{a}\left(\mathrm{J}_{\mathrm{IC}}\right) \\
\mathrm{T}_{\mathrm{C}} \text { Average } \\
\mathrm{K}_{\mathrm{j}} \mathrm{c}\end{array}$ & $\begin{array}{l}\mathbf{J}=\mathbf{C}(\Delta \mathbf{a})^{\mathbf{n}} \\
: 661.98 \mathrm{~kJ} / \mathrm{m}^{2} \\
: 0.9861 \\
: 487.4 \mathrm{~kJ} / \mathrm{m}^{2} \\
: 0.523 \mathrm{~mm} \\
: 395.3 \\
: 454.5 \mathrm{~kJ} / \mathrm{m}^{2} \\
: 0.451 \mathrm{~mm} \\
: 403.5 \\
: 436.7 \mathrm{MPa}-\mathrm{m}^{0.5}\end{array}$ & $\begin{array}{l}\text { Exponent } n \\
(14 \text { Data Points) } \\
\left(2783.0 \text { in.-lb/in. }{ }^{2}\right) \\
(0.0206 \text { in.) } \\
\left(\mathrm{J}_{\mathrm{IC}} \text { at } 0.20\right) \\
\left(2595.5 \text { in.-lb/in. }{ }^{2}\right) \\
(0.0178 \text { in. }) \\
\left(\mathrm{J}_{\mathrm{IC}} \text { at } 0.15\right)\end{array}$ & 0.4726 \\
\hline
\end{tabular}

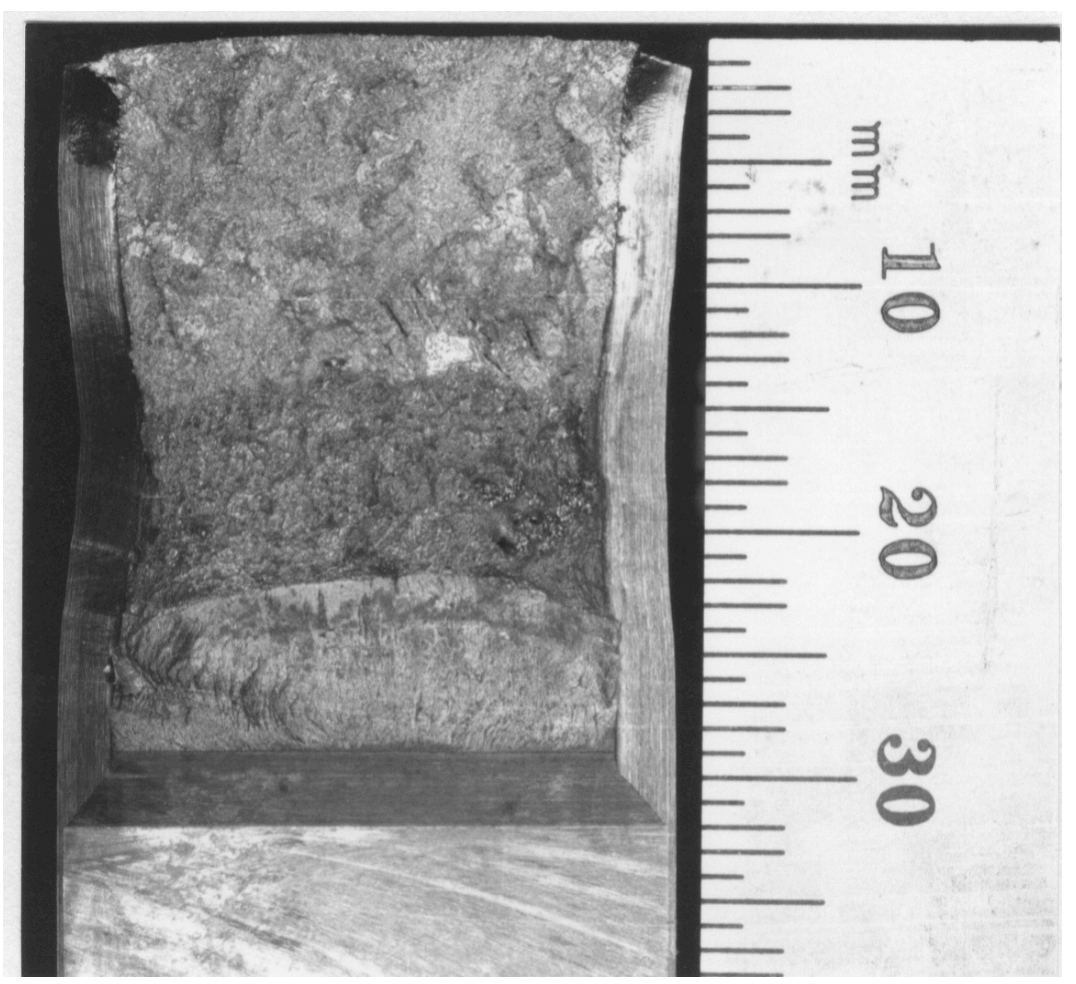

Figure C-2. Fracture surface of the cold-leg check valve CA4 tested at room temperature after $13 y$ of service at $264^{\circ} \mathrm{C}$ 


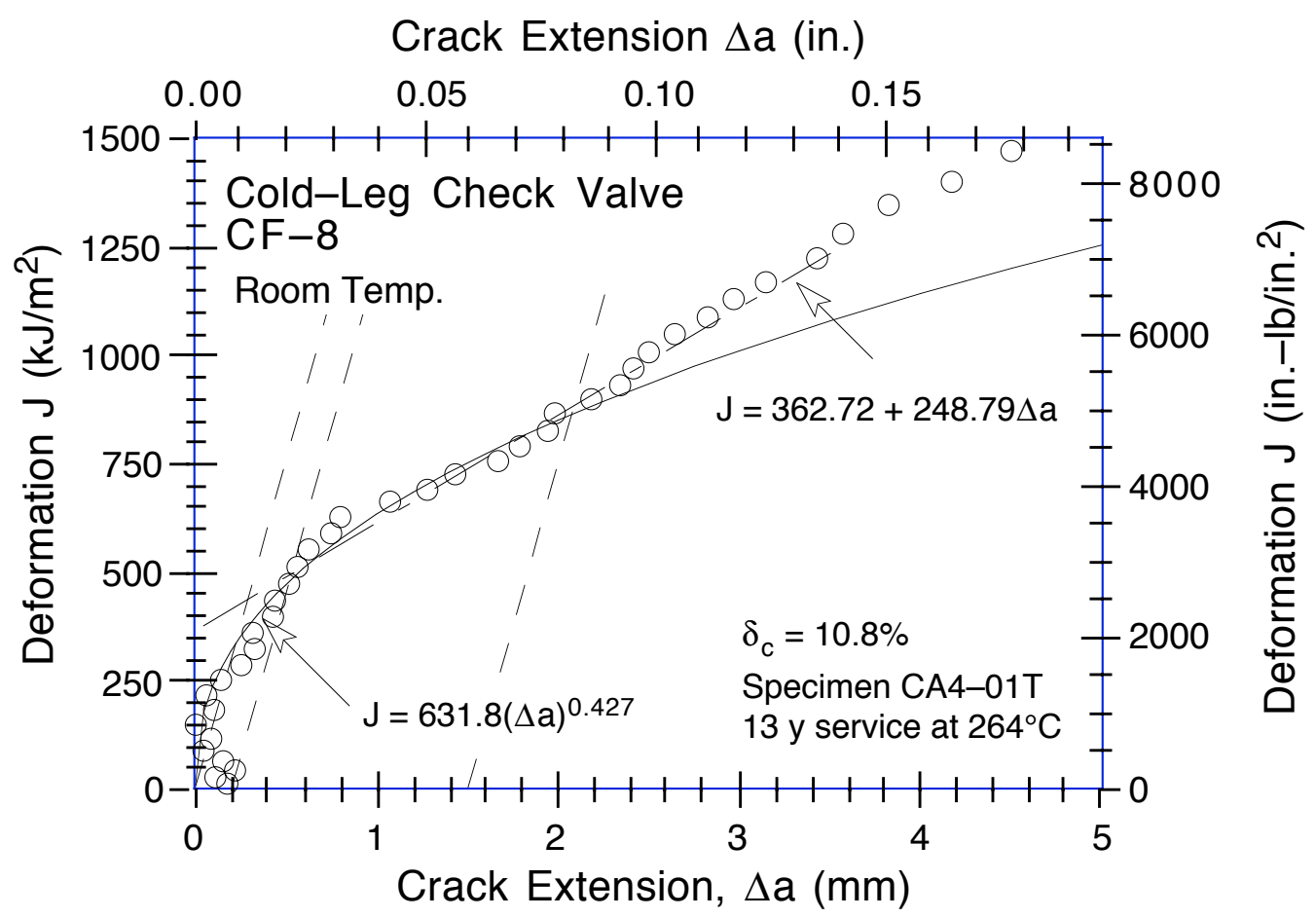

Figure $C-3$. Deformation $J-R$ Curve at room temperature for the cold-leg check valve CA4 after $13 y$ of service at $264^{\circ} \mathrm{C}$

Crack Extension $\Delta$ a (in.)

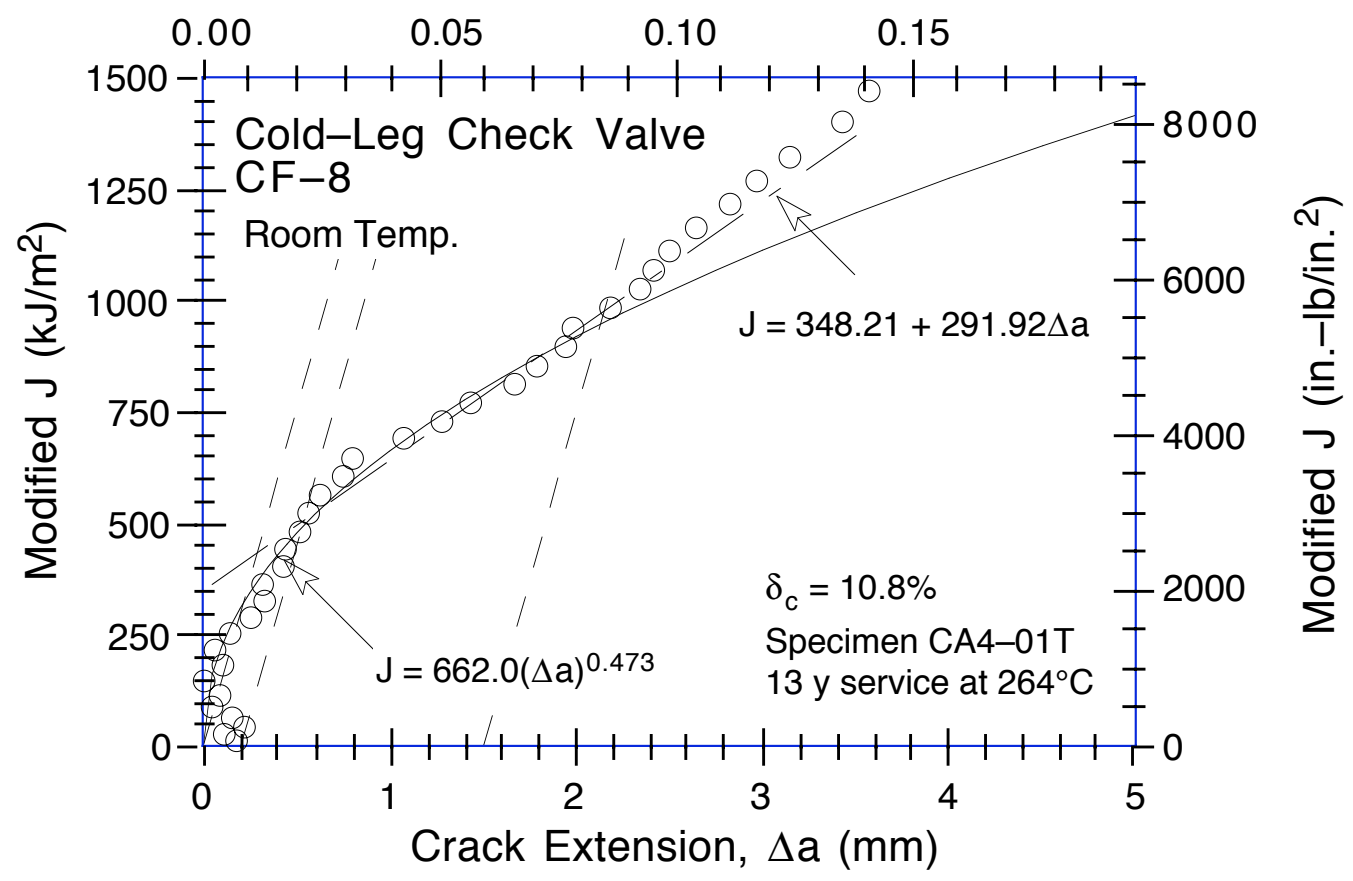

Figure $C-4$. Modified J-R Curve at room temperature for the cold-leg check valve CA4 after 13 y of service at $264^{\circ} \mathrm{C}$ 
Table C-5. Test data for specimen CA4-02T

\begin{tabular}{|c|c|c|c|c|c|}
\hline $\begin{array}{l}\text { Test Nun } \\
\text { Material } \\
\text { Aging Te } \\
\text { Spec. Th } \\
\text { Spec. Wi }\end{array}$ & $\begin{array}{l}\text { ber } \\
\text { ype } \\
\text { np. } \\
\text { kness } \\
\text { th }\end{array}$ & $\begin{array}{l}\mathrm{mm} \\
\mathrm{mm}\end{array}$ & $\begin{array}{l}\text { Test } \\
\text { Heat } \\
\text { Aging } \\
\text { Net T } \\
\text { Flow }\end{array}$ & : & $\begin{array}{l}0 \mathrm{~h} \\
1 \mathrm{~mm} \\
50 \mathrm{MPa}\end{array}$ \\
\hline $\begin{array}{c}\text { Unload } \\
\text { Number }\end{array}$ & $\begin{array}{c}J_{d} \\
\left(k J / m^{2}\right)\end{array}$ & $\begin{array}{c}J_{m} \\
\left(k J / m^{2}\right)\end{array}$ & $\begin{array}{c}\Delta \mathrm{a} \\
(\mathrm{m} \mathrm{m})\end{array}$ & $\begin{array}{l}\text { Load } \\
(\mathrm{kN})\end{array}$ & $\begin{array}{c}\text { Deflection } \\
(\mathrm{m} \mathrm{m})\end{array}$ \\
\hline 1 & 13.15 & 13.15 & -0.0142 & 18.339 & 0.253 \\
\hline 2 & 39.06 & 39.05 & -0.0175 & 22.886 & 0.504 \\
\hline 3 & 75.24 & 75.14 & -0.0447 & 25.528 & 0.805 \\
\hline 4 & 114.89 & 114.70 & -0.0593 & 27.161 & 1.106 \\
\hline 5 & 156.29 & 157.49 & 0.1113 & 28.486 & 1.407 \\
\hline 6 & 184.78 & 185.81 & 0.0939 & 29.332 & 1.609 \\
\hline 7 & 214.05 & 216.10 & 0.1835 & 29.737 & 1.810 \\
\hline 8 & 243.88 & 245.52 & 0.1525 & 30.389 & 2.008 \\
\hline 9 & 274.46 & 277.47 & 0.2433 & 30.793 & 2.212 \\
\hline 10 & 302.51 & 308.83 & 0.4407 & 31.337 & 2.409 \\
\hline 11 & 333.02 & 339.75 & 0.4629 & 31.406 & 2.610 \\
\hline 12 & 363.61 & 372.47 & 0.5667 & 31.636 & 2.810 \\
\hline 13 & 393.01 & 404.98 & 0.7060 & 31.815 & 3.009 \\
\hline 14 & 423.98 & 437.68 & 0.7772 & 31.964 & 3.211 \\
\hline 15 & 454.88 & 470.54 & 0.8522 & 32.270 & 3.410 \\
\hline 16 & 482.98 & 504.73 & 1.0688 & 31.907 & 3.611 \\
\hline 17 & 511.76 & 537.12 & 1.1891 & 32.315 & 3.809 \\
\hline 18 & 547.47 & 579.68 & 1.4006 & 32.199 & 4.059 \\
\hline 19 & 583.81 & 622.16 & 1.5766 & 31.789 & 4.311 \\
\hline 20 & 615.76 & 664.29 & 1.8499 & 31.382 & 4.559 \\
\hline 21 & 653.80 & 713.02 & $\begin{array}{l}2.1166 \\
\end{array}$ & 31.167 & 4.849 \\
\hline 22 & 686.96 & 756.62 & 2.3618 & 30.899 & 5.109 \\
\hline 23 & 729.27 & 807.05 & 2.5402 & 30.611 & 5.410 \\
\hline 24 & 765.04 & 858.88 & 2.8714 & 30.468 & 5.710 \\
\hline 25 & 806.57 & 908.89 & 3.0358 & 30.199 & 6.012 \\
\hline 26 & 857.20 & 978.52 & 3.3770 & 29.744 & 6.411 \\
\hline 27 & 904.82 & 1046.75 & 3.7220 & 29.074 & 6.813 \\
\hline 28 & 950.91 & 1112.52 & 4.0310 & 28.497 & 7.206 \\
\hline 29 & 1015.46 & 1197.04 & 4.3200 & 27.904 & 7.707 \\
\hline 30 & 1058.96 & 1282.45 & 4.8867 & 26.693 & 8.208 \\
\hline 31 & 1107.87 & 1378.94 & 5.4831 & 25.041 & 8.807 \\
\hline 32 & 1154.52 & 1473.53 & 6.0447 & 24.472 & 9.407 \\
\hline 33 & 1217.98 & 1567.02 & 6.3724 & 23.992 & 10.005 \\
\hline 34 & 1281.94 & 1662.96 & 6.6979 & 23.301 & 10.606 \\
\hline 35 & 1320.15 & 1758.46 & 7.2468 & 21.823 & 11.209 \\
\hline 36 & 1350.21 & 1863.14 & 7.9197 & 20.353 & 11.911 \\
\hline 37 & 1398.62 & 1962.83 & 8.3544 & 19.481 & 12.609 \\
\hline 38 & 1427.55 & 2063.56 & 8.9290 & 17.744 & 13.310 \\
\hline 39 & 1437.16 & 2155.22 & 9.5555 & 16.562 & 14.004 \\
\hline 40 & 1478.57 & 2245.44 & 9.9090 & 15.873 & 14.706 \\
\hline 41 & 1499.98 & 2337.17 & 10.3935 & 14.633 & 15.406 \\
\hline
\end{tabular}


Table C-6. Deformation J/C and J-R curve results for specimen CA4-02T

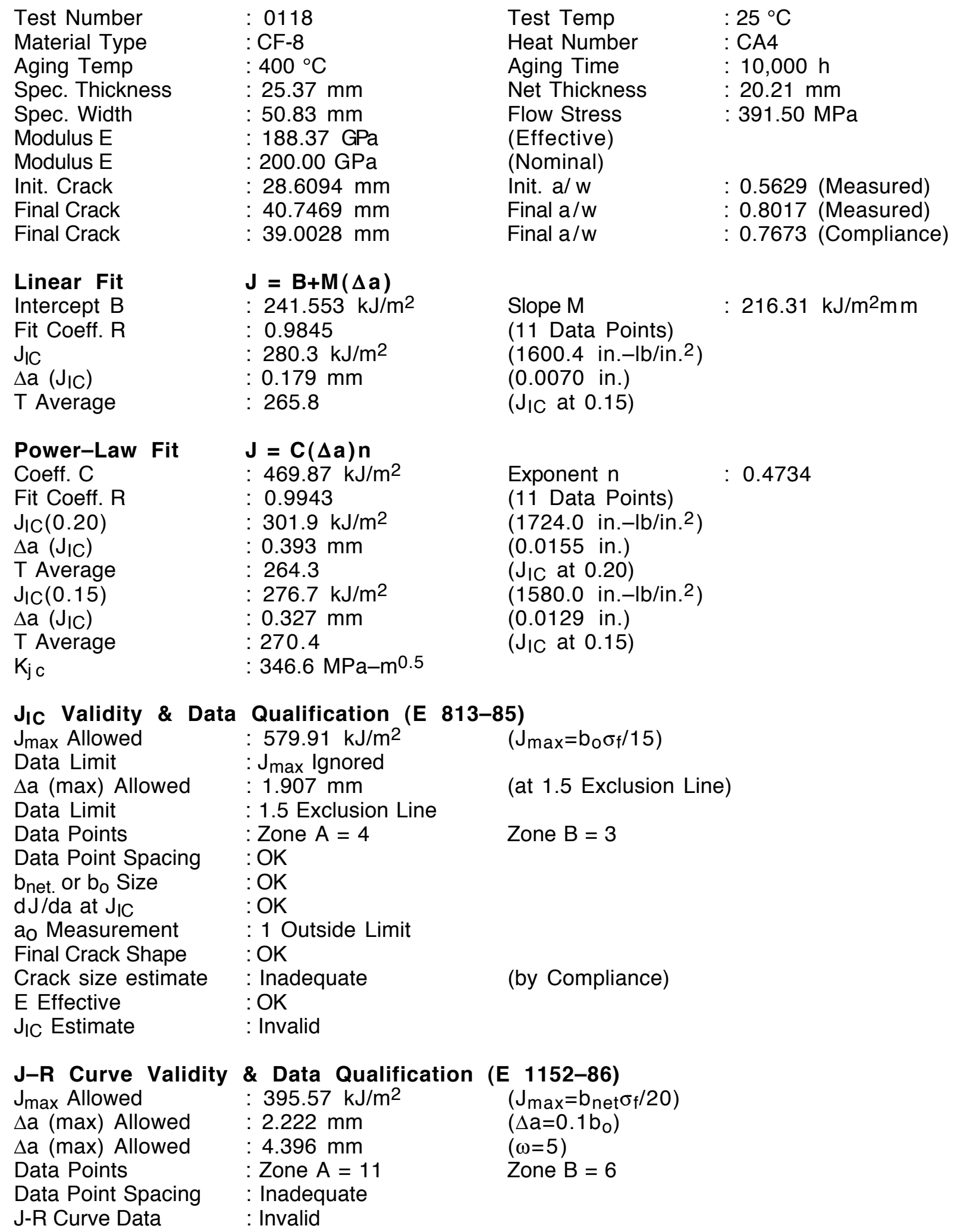


Table $C-7$. Modified J/C and $\mathrm{J}-R$ curve results for specimen CA4-02T

\begin{tabular}{|c|c|c|c|}
\hline $\begin{array}{l}\text { Linear Fit } \\
\text { Intercept B } \\
\text { Fit Coeff. R } \\
\mathrm{J}_{\mathrm{IC}} \\
\Delta \mathrm{a}\left(\mathrm{J}_{\mathrm{IC}}\right) \\
\mathrm{T} \text { Average }\end{array}$ & $\begin{array}{l}\mathbf{J}=\mathbf{B}+\mathbf{M}(\Delta \mathbf{a}) \\
: 233.201 \mathrm{~kJ} / \mathrm{m}^{2} \\
: 0.9894 \\
: 276.6 \mathrm{~kJ} / \mathrm{m}^{2} \\
: 0.177 \mathrm{~mm} \\
: 302.1\end{array}$ & $\begin{array}{l}\text { Slope M } \\
\text { (11 Data Points) } \\
\left(1579.6 \text { in.-lb/in. }{ }^{2}\right) \\
(0.0070 \text { in. }) \\
(\mathrm{J} 1 \mathrm{C} \text { at } 0.15)\end{array}$ & : $245.81 \mathrm{~kJ} / \mathrm{m}^{2} \mathrm{~mm}$ \\
\hline $\begin{array}{l}\text { Power-Law Fit } \\
\text { Coeff. C } \\
\text { Fit Coeff. R } \\
\mathrm{J}_{\mathrm{IC}}(0.20) \\
\Delta \mathrm{a}\left(\mathrm{J}_{\mathrm{IC}}\right) \\
\mathrm{T} \text { Average } \\
\mathrm{J}_{\mathrm{IC}}(0.15) \\
\Delta \mathrm{a} \text { (Jic) } \\
\text { T Average } \\
\mathrm{K}_{\mathrm{i} \text { c }}\end{array}$ & $\begin{array}{l}\mathbf{J}=\mathbf{C}(\Delta \mathbf{a})^{\mathbf{n}} \\
: 491.57 \mathrm{~kJ} / \mathrm{m}^{2} \\
: 0.9960 \\
: 306.2 \mathrm{~kJ} / \mathrm{m}^{2} \\
: 0.396 \mathrm{~mm} \\
: 296.4 \\
: 278.1 \mathrm{~kJ} / \mathrm{m}^{2} \\
: 0.328 \mathrm{~mm} \\
: 302.8 \\
: 360.4 \mathrm{MPa}-\mathrm{m}^{0.5}\end{array}$ & $\begin{array}{l}\text { Exponent } n \\
(11 \text { Data Points) } \\
\left(1748.5 \text { in.-lb/in. }{ }^{2}\right) \\
(0.0156 \text { in.) } \\
\left(\mathrm{J}_{\mathrm{IC}} \text { at } 0.20\right) \\
\left(1588.2 \text { in. }-\mathrm{lb} / \text { in. }^{2}\right) \\
(0.0129 \text { in.) } \\
\left(\mathrm{J}_{\mathrm{IC}} \text { at } 0.15\right)\end{array}$ & 0.5103 \\
\hline
\end{tabular}

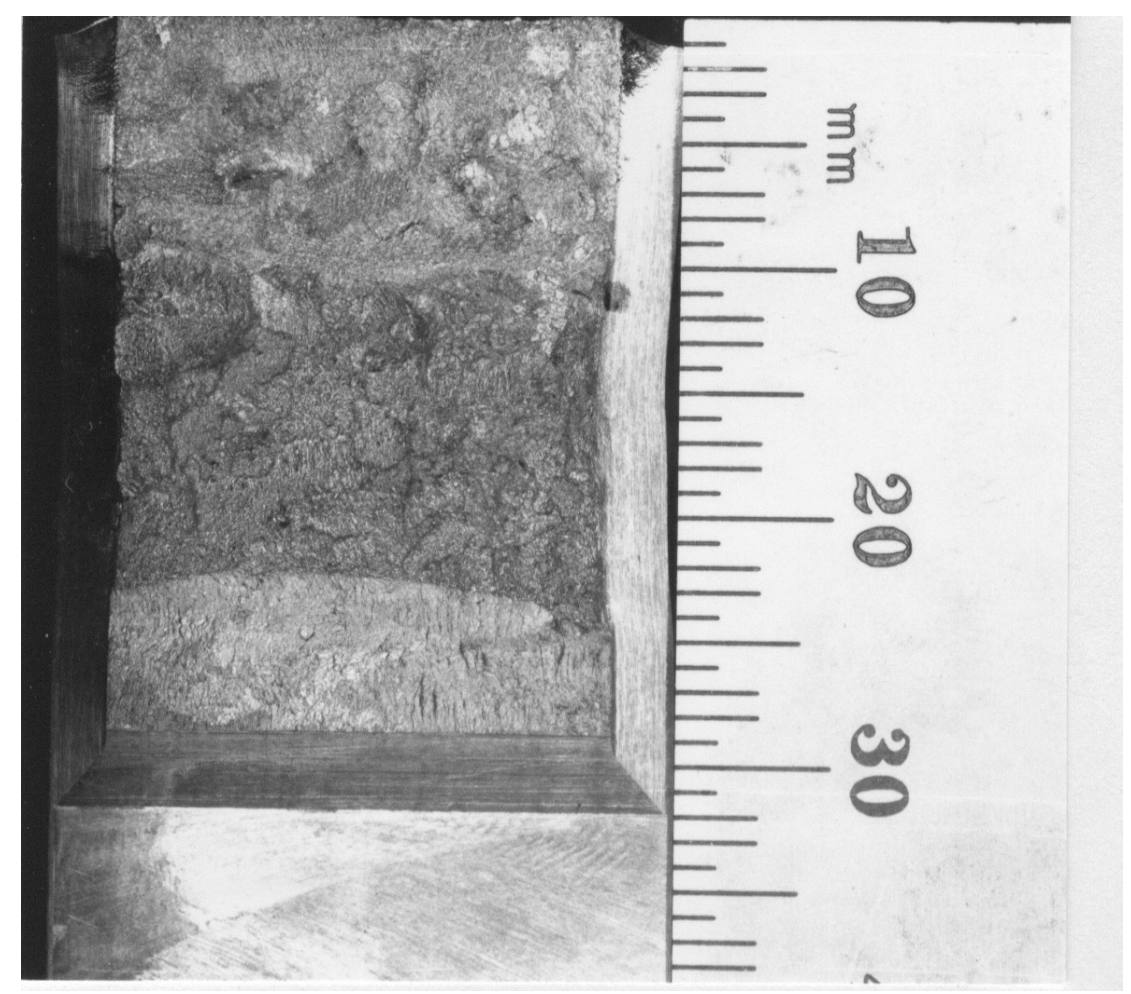

Figure C-5. Fracture surface of service-aged CA4 material from the cold-leg check valve aged further for $10,000 \mathrm{~h}$ at $400^{\circ} \mathrm{C}$ and tested at $25^{\circ} \mathrm{C}$ 


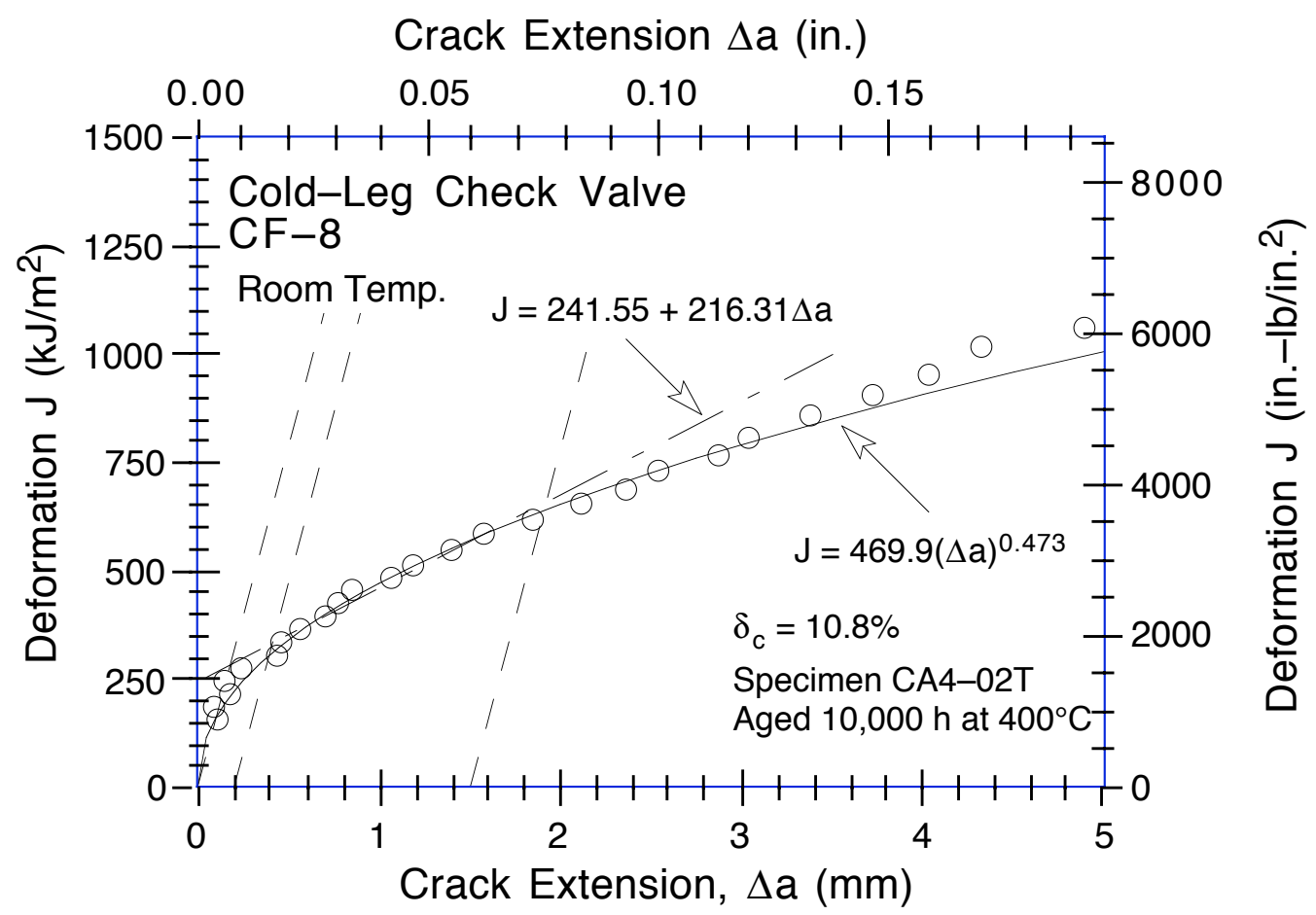

Figure $C-6$. Deformation $J-R$ Curve at room temperature for material from the cold-leg check valve CA4 aged for $10,000 \mathrm{~h}$ at $400^{\circ} \mathrm{C}$ after service

Crack Extension $\Delta$ a (in.)

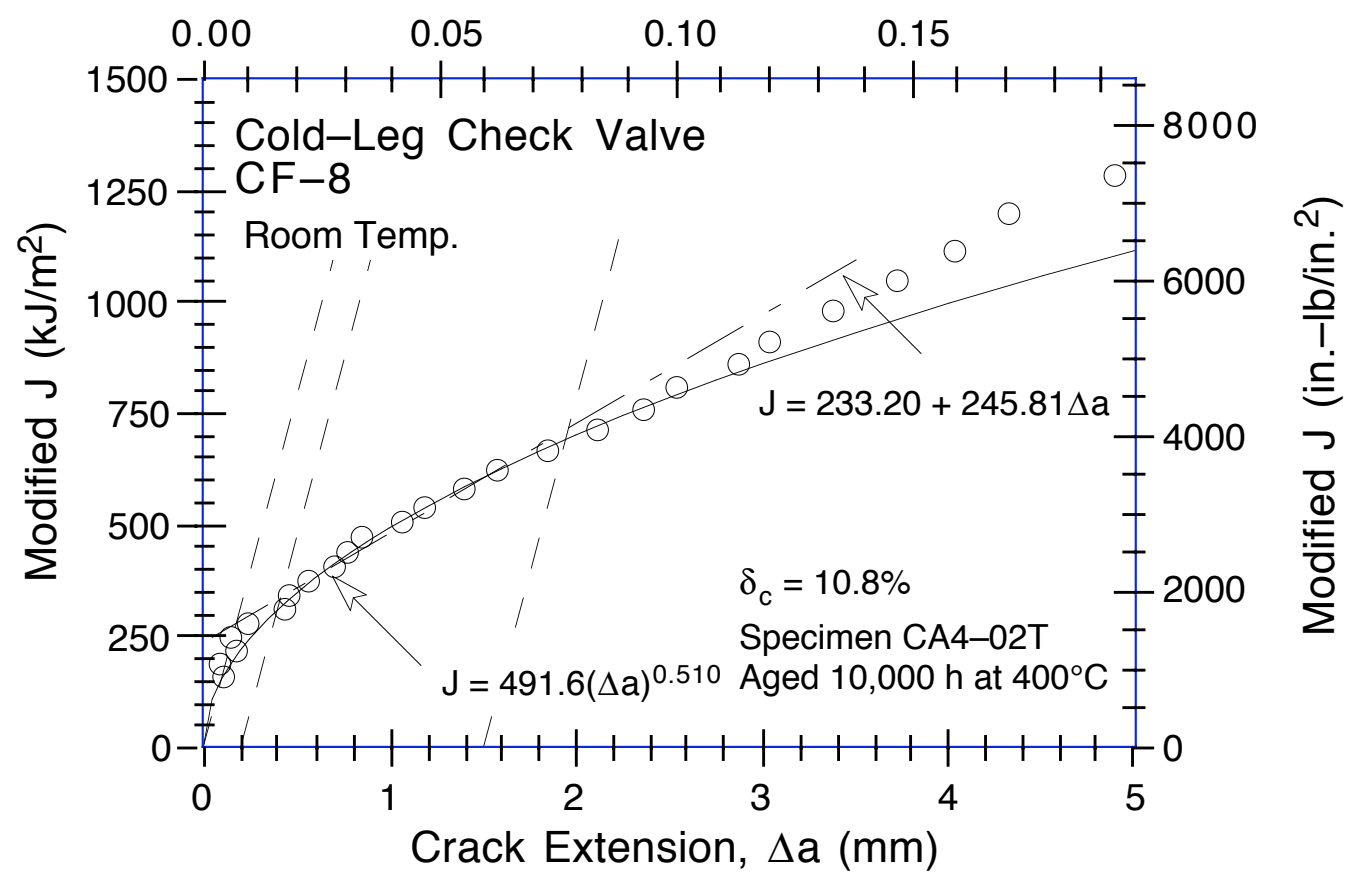

Figure $C-7$. Modified $J-R$ Curve at room temperature for material from the cold-leg check valve CA4 aged for $10,000 \mathrm{~h}$ at $400^{\circ} \mathrm{C}$ after service 
Table C-8. Test data for specimen CA4-01B

\begin{tabular}{|c|c|c|c|c|c|}
\hline \multicolumn{2}{|c|}{$\begin{array}{l}\text { Test Number } \\
\text { Material Type } \\
\text { Aging Temp. } \\
\text { Spec. Thickness } \\
\text { Spec. Width }\end{array}$} & $\begin{array}{l}: 0064 \\
: C F-8 \\
: 550^{\circ} \mathrm{C} \\
: 25.37 \mathrm{~mm} \\
: 50.80 \mathrm{~mm}\end{array}$ & \multicolumn{2}{|c|}{$\begin{array}{l}\text { Test Temp. } \\
\text { Heat Number } \\
\text { Aging Time } \\
\text { Net. Thickness } \\
\text { Flow Stress }\end{array}$} & $\begin{array}{c}\mathrm{mm} \\
0 \mathrm{MPa}\end{array}$ \\
\hline $\begin{array}{c}\text { Unload } \\
\text { Number }\end{array}$ & $\begin{array}{c}J_{d} \\
\left(k J / m^{2}\right)\end{array}$ & $\begin{array}{c}J_{m} \\
\left(k J / m^{2}\right)\end{array}$ & $\begin{array}{c}\Delta \mathrm{a} \\
(\mathrm{m} \mathrm{m})\end{array}$ & $\begin{array}{l}\text { Load } \\
(\mathrm{kN})\end{array}$ & $\begin{array}{c}\text { Deflection } \\
(\mathrm{m} \mathrm{m})\end{array}$ \\
\hline 1 & 9.44 & 9.43 & -0.0234 & 13.753 & 0.257 \\
\hline 2 & 28.57 & 28.79 & 0.1610 & 16.375 & 0.510 \\
\hline 3 & 53.58 & 53.51 & 0.0511 & 17.611 & 0.808 \\
\hline 4 & 85.38 & 85.24 & 0.0348 & 18.721 & 1.157 \\
\hline 5 & 118.76 & 118.73 & 0.0526 & 19.594 & 1.509 \\
\hline 6 & 152.93 & 154.06 & 0.1895 & 20.222 & 1.862 \\
\hline 7 & 188.91 & 188.90 & 0.0826 & $\begin{array}{l}20.774 \\
\end{array}$ & 2.209 \\
\hline 8 & 223.44 & 227.19 & 0.3793 & 21.401 & 2.561 \\
\hline 9 & 261.94 & 263.82 & 0.2537 & 21.868 & 2.910 \\
\hline 10 & 296.86 & 304.08 & 0.5658 & 22.248 & 3.261 \\
\hline 11 & 336.25 & 344.01 & 0.5938 & 22.561 & 3.621 \\
\hline 12 & 373.62 & 384.12 & 0.7191 & 22.867 & 3.964 \\
\hline 13 & 411.74 & 424.77 & 0.8239 & 23.125 & 4.311 \\
\hline 14 & 450.03 & 466.73 & 0.9613 & 23.239 & 4.662 \\
\hline 15 & 490.03 & 508.44 & 1.0200 & 23.496 & 5.010 \\
\hline 16 & 526.04 & 552.08 & 1.2618 & 23.708 & 5.360 \\
\hline 17 & 572.89 & 593.63 & 1.1071 & 23.992 & 5.710 \\
\hline 18 & 604.21 & 640.04 & 1.5180 & 23.954 & 6.063 \\
\hline 19 & 654.38 & 680.99 & 1.2850 & 24.163 & 6.412 \\
\hline 20 & 681.38 & 727.98 & 1.7625 & 24.236 & 6.759 \\
\hline 21 & 728.53 & 769.83 & 1.6439 & 24.212 & 7.107 \\
\hline 22 & 753.16 & 817.57 & 2.1348 & 24.017 & 7.458 \\
\hline 23 & 794.97 & 860.11 & 2.1494 & 23.780 & 7.808 \\
\hline 24 & $\begin{array}{l}815.57 \\
815\end{array}$ & 907.21 & $\begin{array}{l}2.6585 \\
2.65\end{array}$ & 23.500 & $\begin{array}{l}8.159 \\
8.159\end{array}$ \\
\hline 25 & 849.30 & 950.25 & 2.8289 & 23.323 & 8.506 \\
\hline 26 & 878.69 & 996.38 & 3.1216 & 23.125 & 8.857 \\
\hline 27 & 906.39 & 1041.60 & 3.4148 & 22.837 & 9.207 \\
\hline 28 & 945.98 & 1094.52 & 3.6264 & 22.364 & 9.619 \\
\hline 29 & 975.27 & 1145.75 & 3.9596 & 22.079 & 10.012 \\
\hline 30 & 1023.90 & 1209.84 & 4.1807 & 21.582 & 10.516 \\
\hline 31 & 1070.69 & 1287.07 & 4.5895 & 21.269 & 11.110 \\
\hline 32 & 1112.58 & 1364.25 & 5.0364 & 20.635 & 11.714 \\
\hline 33 & 1158.09 & 1438.41 & 5.3790 & 19.982 & 12.310 \\
\hline 34 & 1205.31 & 1526.53 & 5.8386 & 19.287 & 13.012 \\
\hline $\begin{array}{l}34 \\
35\end{array}$ & 1242.99 & 1612.18 & $\begin{array}{l}6.3479 \\
6.340\end{array}$ & 18.539 & 13.710 \\
\hline 36 & 1283.47 & 1696.59 & 6.7892 & 17.753 & 14.413 \\
\hline 37 & 1307.39 & 1779.99 & 7.3584 & 17.086 & 15.112 \\
\hline 38 & 1342.81 & 1861.46 & 7.7776 & 16.502 & 15.811 \\
\hline
\end{tabular}


Table C-9. Deformation $J_{I C}$ and $J-R$ curve results for specimen CA4-01B

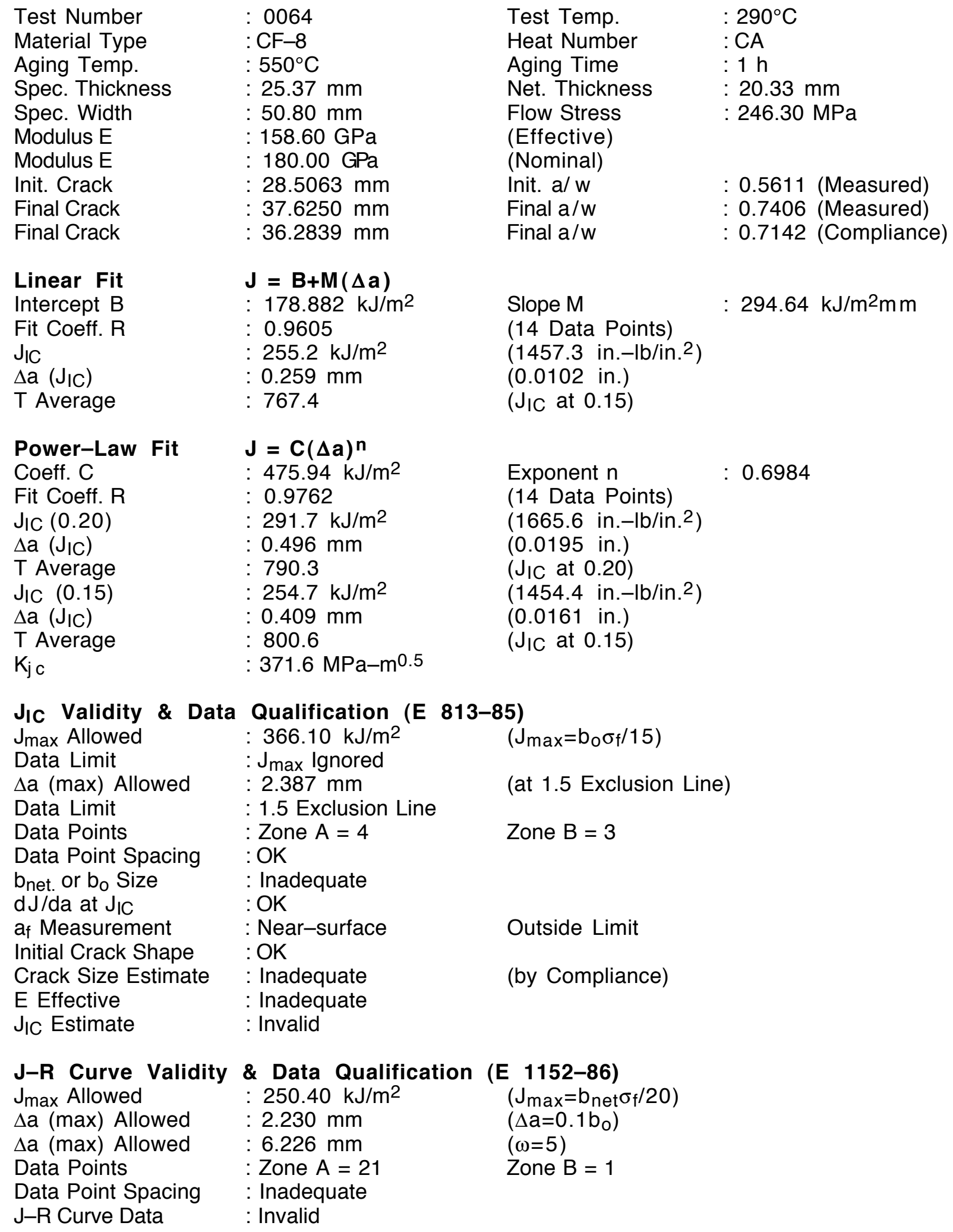


Table C-10. Modified JIC and $J-R$ curve results for specimen CA4-01B

\begin{tabular}{|c|c|c|c|}
\hline $\begin{array}{l}\text { Linear Fit } \\
\text { Intercept B } \\
\text { Fit Coeff. R } \\
\mathrm{J}_{\mathrm{IC}} \\
\Delta \mathrm{a}\left(\mathrm{J}_{\mathrm{IC}}\right) \\
\mathrm{T} \text { Average }\end{array}$ & $\begin{array}{l}\mathbf{J}=\mathbf{B}+\mathbf{M}(\Delta \mathbf{a}) \\
: 179.004 \mathrm{~kJ} / \mathrm{m}^{2} \\
: 0.9673 \\
: 265.3 \mathrm{~kJ} / \mathrm{m}^{2} \\
: 0.269 \mathrm{~mm} \\
: 834.9\end{array}$ & $\begin{array}{l}\text { Slope M } \\
\text { (14 Data Points) } \\
\left(1515.1 \text { in.-lb/in. }{ }^{2}\right) \\
(0.0106 \text { in.) } \\
\left(J_{I C} \text { at } 0.15\right)\end{array}$ & $320.56 \mathrm{~kJ} / \mathrm{m}^{2} \mathrm{~mm}$ \\
\hline $\begin{array}{l}\text { Power-Law Fit } \\
\text { Coeff. C } \\
\text { Fit Coeff. R } \\
\mathrm{J}_{\mathrm{IC}}(0.20) \\
\Delta \mathrm{a}\left(\mathrm{J}_{\mathrm{IC}}\right) \\
\mathrm{T} \text { Average } \\
\mathrm{J}_{\mathrm{IC}}(0.15) \\
\Delta \mathrm{a}\left(\mathrm{J}_{\mathrm{IC}}\right) \\
\mathrm{T}_{\mathrm{C}} \text { Average } \\
\mathrm{K}_{\mathrm{j} \mathrm{c}}\end{array}$ & $\begin{array}{l}\mathbf{J}=\mathbf{C}(\Delta \mathbf{a})^{\mathbf{n}} \\
: 500.42 \mathrm{~kJ} / \mathrm{m}^{2} \\
: 0.9778 \\
: 312.3 \mathrm{~kJ} / \mathrm{m}^{2} \\
: 0.517 \mathrm{~mm} \\
: 845.5 \\
: 272.0 \mathrm{~kJ} / \mathrm{m}^{2} \\
: 0.426 \mathrm{~mm} \\
: 855.9 \\
: 388.3 \mathrm{MPa}-\mathrm{m}^{0.5}\end{array}$ & $\begin{array}{l}\text { Exponent } n \\
(14 \text { Data Points) } \\
\left(1783.6 \text { in.-lb/in. }{ }^{2}\right) \\
(0.0204 \text { in.) } \\
\left(\mathrm{J}_{\mathrm{IC}} \text { at } 0.20\right) \\
\left(1553.4 \text { in. }-\mathrm{lb} / \text { in. }^{2}\right) \\
(0.0168 \text { in.) } \\
\left(\mathrm{J}_{\mathrm{IC}} \text { at } 0.15\right)\end{array}$ & 0.7145 \\
\hline
\end{tabular}

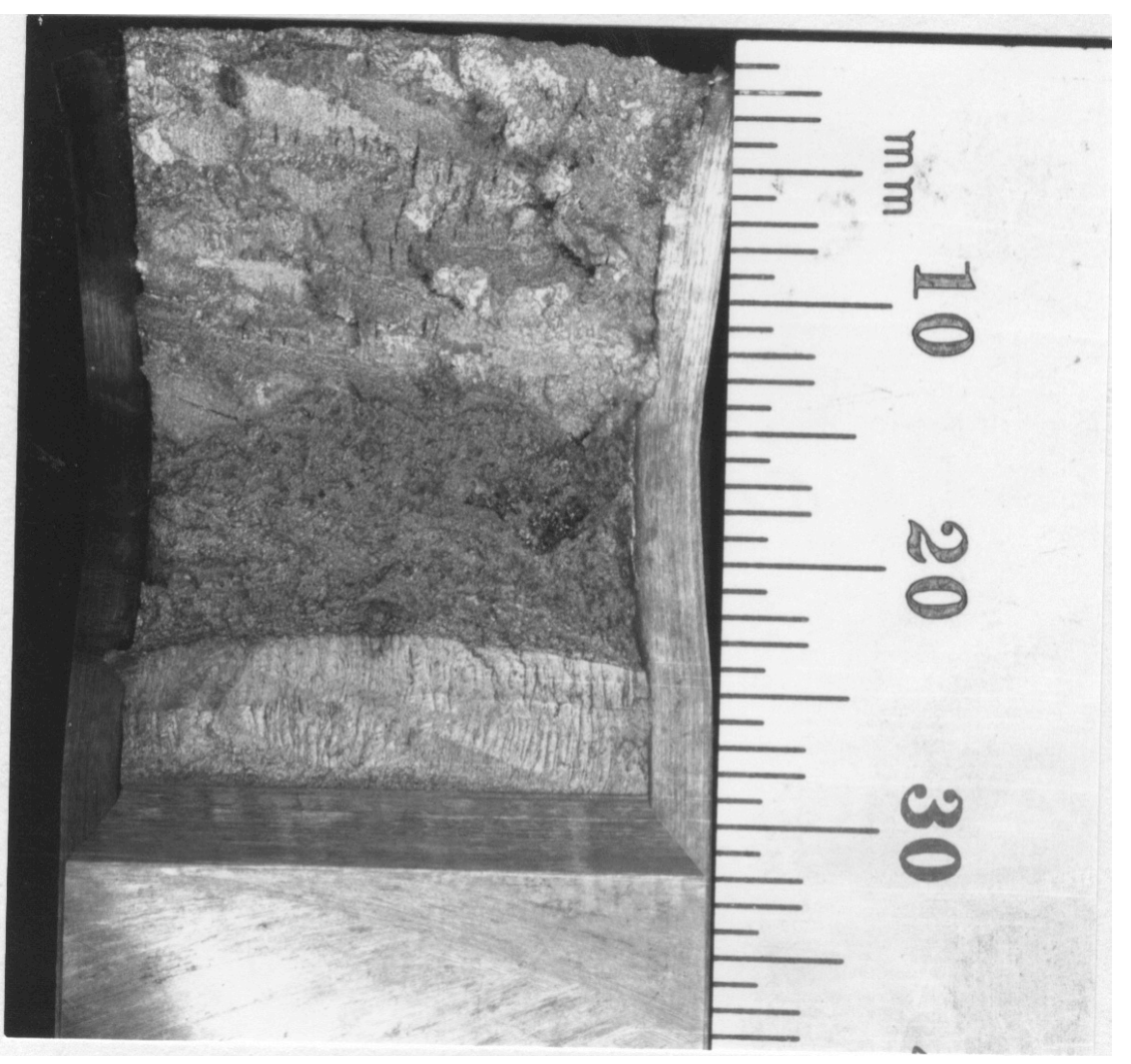

Figure C-8. Fracture surface of recovery-annealed material from the cold-leg check valve CA4 tested at $290^{\circ} \mathrm{C}$ 


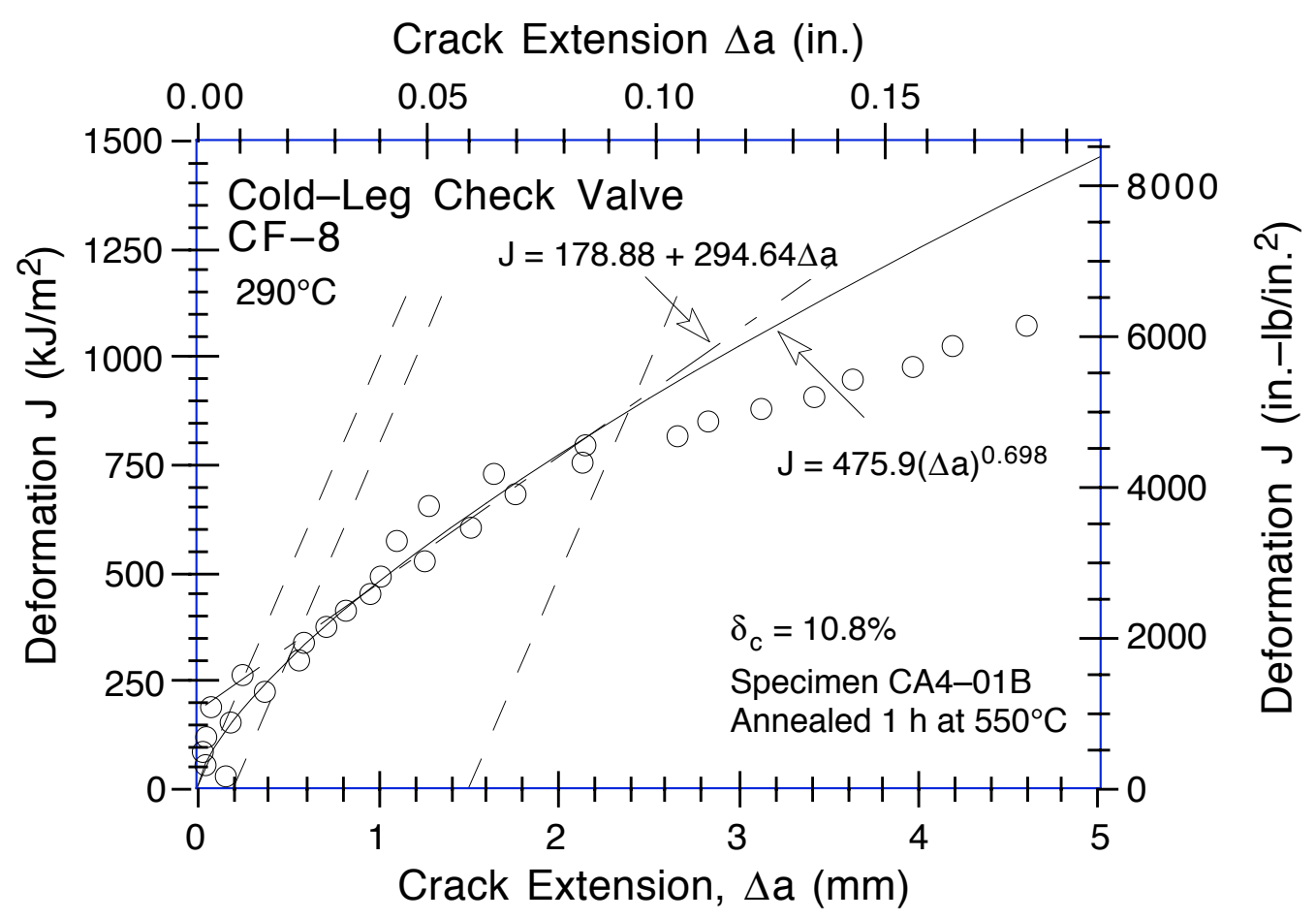

Figure C-9. Deformation J-R Curve at $290^{\circ} \mathrm{C}$ for material from the cold-leg check valve CA4 annealed for $1 \mathrm{~h}$ at $550^{\circ} \mathrm{C}$ and water quenched

Crack Extension $\Delta \mathrm{a}$ (in.)

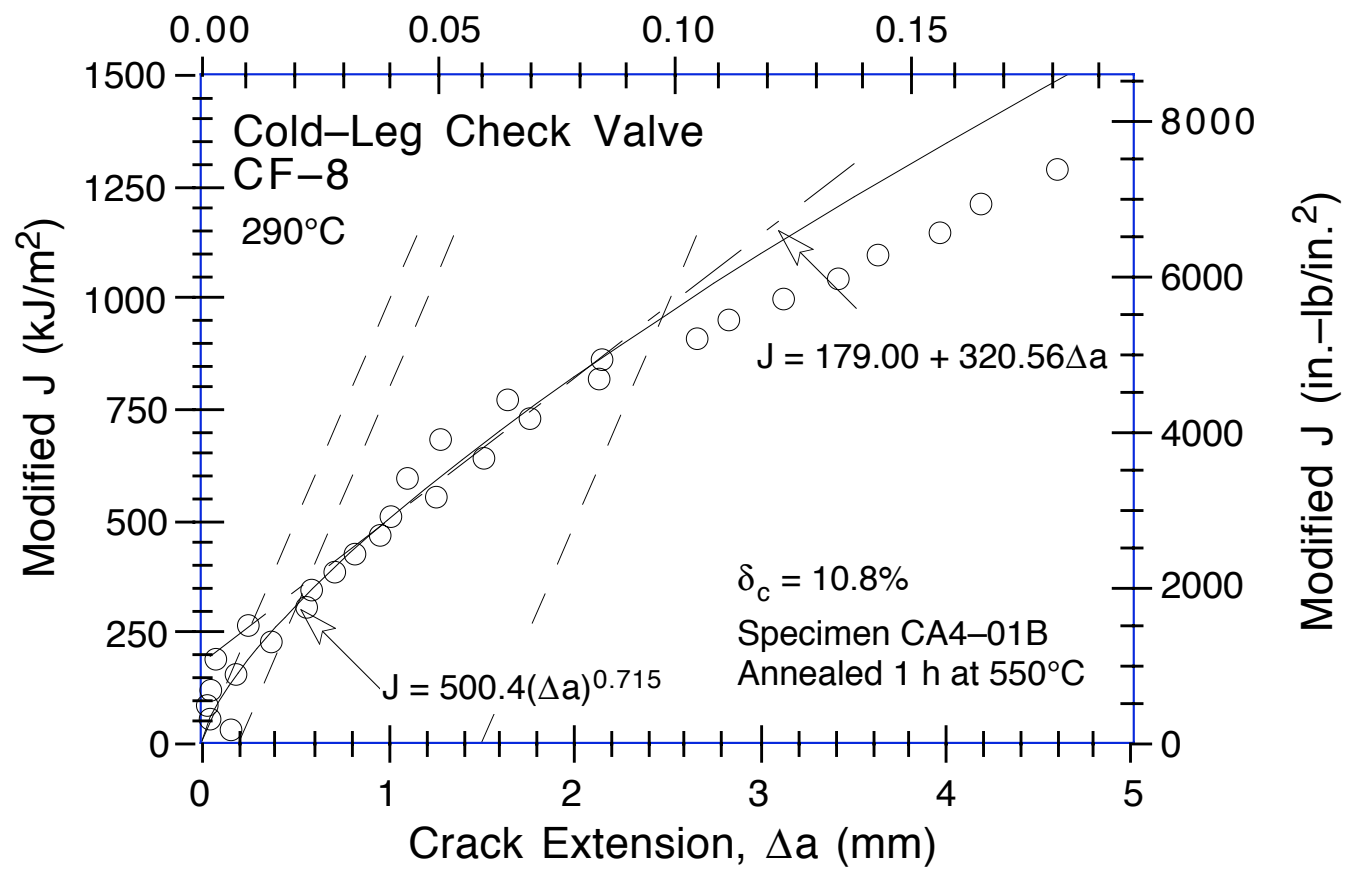

Figure C-10. Modified J-R Curve at $290^{\circ} \mathrm{C}$ for material from the cold-leg check valve CA4 annealed for $1 \mathrm{~h}$ at $550^{\circ} \mathrm{C}$ and water quenched 
Table C-11. Test data for specimen CA4-02B

\begin{tabular}{|c|c|c|c|c|c|}
\hline $\begin{array}{l}\text { Test Nun } \\
\text { Material } \\
\text { Aging Te } \\
\text { Spec. Th } \\
\text { Spec. Wi }\end{array}$ & $\begin{array}{l}\text { ber } \\
\text { ype } \\
\text { hp. } \\
\text { kness } \\
\text { th }\end{array}$ & $\mathrm{mm}$ & $\begin{array}{l}\text { Test } \\
\text { Heat } \\
\text { Aging } \\
\text { Net. } \\
\text { Flow }\end{array}$ & & $\begin{array}{l}00 \mathrm{~h} \\
\mathrm{~mm} \\
0 \mathrm{MPa}\end{array}$ \\
\hline $\begin{array}{l}\text { Unload } \\
\text { Number }\end{array}$ & $\begin{array}{c}J_{d} \\
\left(k J / m^{2}\right)\end{array}$ & $\begin{array}{c}J_{m} \\
\left(k J / m^{2}\right)\end{array}$ & $\begin{array}{c}\Delta \mathrm{a} \\
(\mathrm{m} \mathrm{m})\end{array}$ & $\begin{array}{l}\text { Load } \\
(\mathrm{kN})\end{array}$ & $\begin{array}{c}\text { Deflection } \\
(\mathrm{m} \mathrm{m})\end{array}$ \\
\hline 1 & 7.42 & 7.41 & -0.0503 & 12495 & 0.262 \\
\hline 2 & 20.60 & 20.69 & 0.0554 & 14.193 & 0.455 \\
\hline 3 & 35.74 & 35.87 & 0.0819 & 15.220 & 0.659 \\
\hline 4 & 51.63 & 51.75 & 0.0796 & 15.950 & 0.859 \\
\hline 5 & 67.90 & 68.64 & 0.2515 & 16.622 & 1.058 \\
\hline 6 & 90.30 & 89.97 & 0.0347 & 17.224 & 1.312 \\
\hline 7 & 113.18 & 111.91 & -0.1169 & 17.849 & 1.556 \\
\hline 8 & 134.80 & 136.39 & 0.2590 & 18.354 & 1.809 \\
\hline 9 & 158.95 & 159.04 & 0.0942 & 18.834 & 2.060 \\
\hline 10 & 181.67 & 183.38 & 0.2480 & 19.247 & 2.301 \\
\hline 11 & 213.90 & 212.98 & 0.0345 & 19.769 & 2.606 \\
\hline 12 & 247.31 & 243.83 & -0.1444 & 20.089 & 2.909 \\
\hline 13 & 271.94 & 276.75 & 0.3755 & 20.562 & 3.209 \\
\hline 14 & 304.30 & 306.96 & 0.2552 & 20.905 & 3.510 \\
\hline 15 & 334.11 & 340.63 & 0.4496 & 21.247 & 3.810 \\
\hline 16 & 364.73 & 373.69 & 0.5622 & 21.480 & 4.110 \\
\hline 17 & 394.08 & 407.87 & 0.7661 & 21.729 & 4.410 \\
\hline 18 & 427.80 & 441.49 & 0.7621 & 21.974 & 4.709 \\
\hline 19 & 458.89 & 476.77 & 0.9131 & 22.197 & 5.008 \\
\hline 20 & 493.65 & 511.76 & 0.9205 & 22.433 & 5.309 \\
\hline 21 & 519.37 & 549.26 & 1.2886 & 22.535 & 5.613 \\
\hline 22 & 551.92 & 583.92 & 1.3506 & 22.572 & 5.910 \\
\hline 23 & 588.73 & 620.22 & 1.3366 & 22.609 & 6.211 \\
\hline 24 & 615.36 & 657.90 & 1.6233 & 22.593 & 6.510 \\
\hline 25 & 652.20 & 692.91 & 1.5784 & 22.670 & 6.806 \\
\hline 26 & 671.68 & 733.07 & 2.0614 & 22.533 & 7.116 \\
\hline 27 & 703.54 & 767.60 & $\begin{array}{l}2.1208 \\
\end{array}$ & 22.499 & 7.409 \\
\hline 28 & 728.66 & 812.71 & 2.5423 & 22.278 & 7.757 \\
\hline 29 & 765.72 & 855.11 & $\begin{array}{l}2.6491 \\
\end{array}$ & 22.009 & 8.107 \\
\hline 30 & 794.90 & 906.37 & 3.0662 & 21.676 & 8.507 \\
\hline 31 & 840.26 & 954.39 & 3.1137 & 21.610 & 8.905 \\
\hline 32 & 867.30 & 1007.21 & 3.5503 & 21.239 & 9.311 \\
\hline 33 & 909.20 & 1068.70 & 3.8622 & 20.760 & 9.807 \\
\hline 34 & 949.05 & 1131.46 & 4.2061 & 20.246 & 10.311 \\
\hline 35 & 991.94 & 1205.99 & 4.6509 & 19.737 & 10.909 \\
\hline 36 & 1037.69 & 1278.64 & 5.0059 & 18.917 & 11.511 \\
\hline 37 & 1070.75 & 1363.07 & 5.6427 & 18.110 & 12.210 \\
\hline 38 & 1110.87 & 1444.01 & 6.1182 & 17.203 & 12.910 \\
\hline 39 & 1148.95 & 1524.53 & 6.5846 & 16.654 & 13.607 \\
\hline 40 & 1183.54 & 1604.70 & 7.0582 & 16.074 & 14.307 \\
\hline 41 & 1217.87 & 1684.53 & 7.5061 & 15.465 & 15.011 \\
\hline 42 & 1231.04 & 1762.46 & 8.1139 & 14.286 & 15.716 \\
\hline
\end{tabular}


Table C-12. Deformation $J_{I C}$ and $J-R$ curve results for specimen CA4-02B

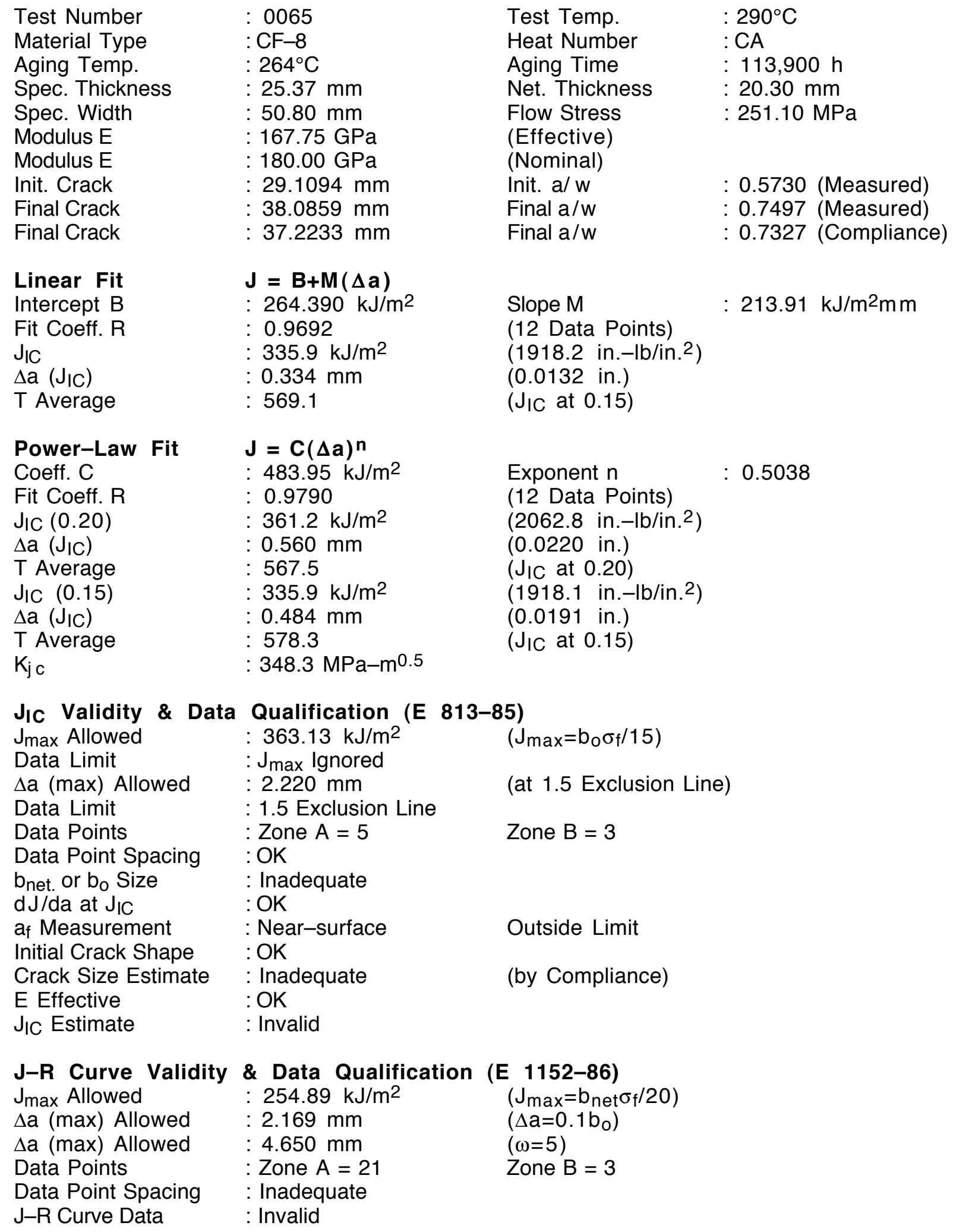


Table C-13. Modified J/C and J-R curve results for specimen CA4-02B

\begin{tabular}{|c|c|c|c|}
\hline $\begin{array}{l}\text { Linear Fit } \\
\text { Intercept B } \\
\text { Fit Coeff. R } \\
\mathrm{J}_{\mathrm{IC}} \\
\Delta \mathrm{a}\left(\mathrm{J}_{\mathrm{IC}}\right) \\
\mathrm{T} \text { Average }\end{array}$ & $\begin{array}{l}\mathbf{J}=\mathbf{B}+\mathbf{M}(\Delta \mathbf{a}) \\
: 250.099 \mathrm{~kJ} / \mathrm{m}^{2} \\
: 0.9787 \\
: 332.8 \mathrm{~kJ} / \mathrm{m}^{2} \\
: 0.331 \mathrm{~mm} \\
: 664.2\end{array}$ & $\begin{array}{l}\text { Slope } M \\
(12 \text { Data Points) } \\
\left(1900.4 \text { in.-lb/in. }{ }^{2}\right) \\
(0.0130 \text { in. }) \\
\left(J_{I C} \text { at } 0.15\right)\end{array}$ & : $249.63 \mathrm{~kJ} / \mathrm{m}^{2} \mathrm{~mm}$ \\
\hline $\begin{array}{l}\text { Power-Law Fit } \\
\text { Coeff. C } \\
\text { Fit Coeff. R } \\
\mathrm{J}_{\mathrm{IC}}(0.20) \\
\Delta \mathrm{a}\left(\mathrm{J}_{\mathrm{IC}}\right) \\
\text { T Average } \\
\mathrm{J}_{\mathrm{IC}}(0.15) \\
\Delta \mathrm{a}\left(\mathrm{J}_{\mathrm{IC}}\right) \\
\mathrm{T}_{\mathrm{C}} \text { Average } \\
\mathrm{K}_{\mathrm{j}} \mathrm{c}\end{array}$ & $\begin{array}{l}\mathbf{J}=\mathbf{C}(\Delta \mathbf{a})^{\mathbf{n}} \\
: 506.05 \mathrm{~kJ} / \mathrm{m}^{2} \\
: 0.9843 \\
: 370.8 \mathrm{~kJ} / \mathrm{m}^{2} \\
: 0.569 \mathrm{~mm} \\
: 649.3 \\
: 341.3 \mathrm{~kJ} / \mathrm{m}^{2} \\
: 0.490 \mathrm{~mm} \\
: 660.6 \\
: 366.5 \mathrm{MPa}-\mathrm{m}^{0.5}\end{array}$ & $\begin{array}{l}\text { Exponent } n \\
(12 \text { Data Points) } \\
\left(2117.1 \text { in.-lb/in. }{ }^{2}\right) \\
(0.0224 \text { in.) } \\
\left(J_{I C} \text { at } 0.20\right) \\
\left(1948.7 \text { in.-lb/in. }{ }^{2}\right) \\
(0.0193 \text { in. }) \\
\left(J_{I C} \text { at } 0.15\right)\end{array}$ & 0.5519 \\
\hline
\end{tabular}

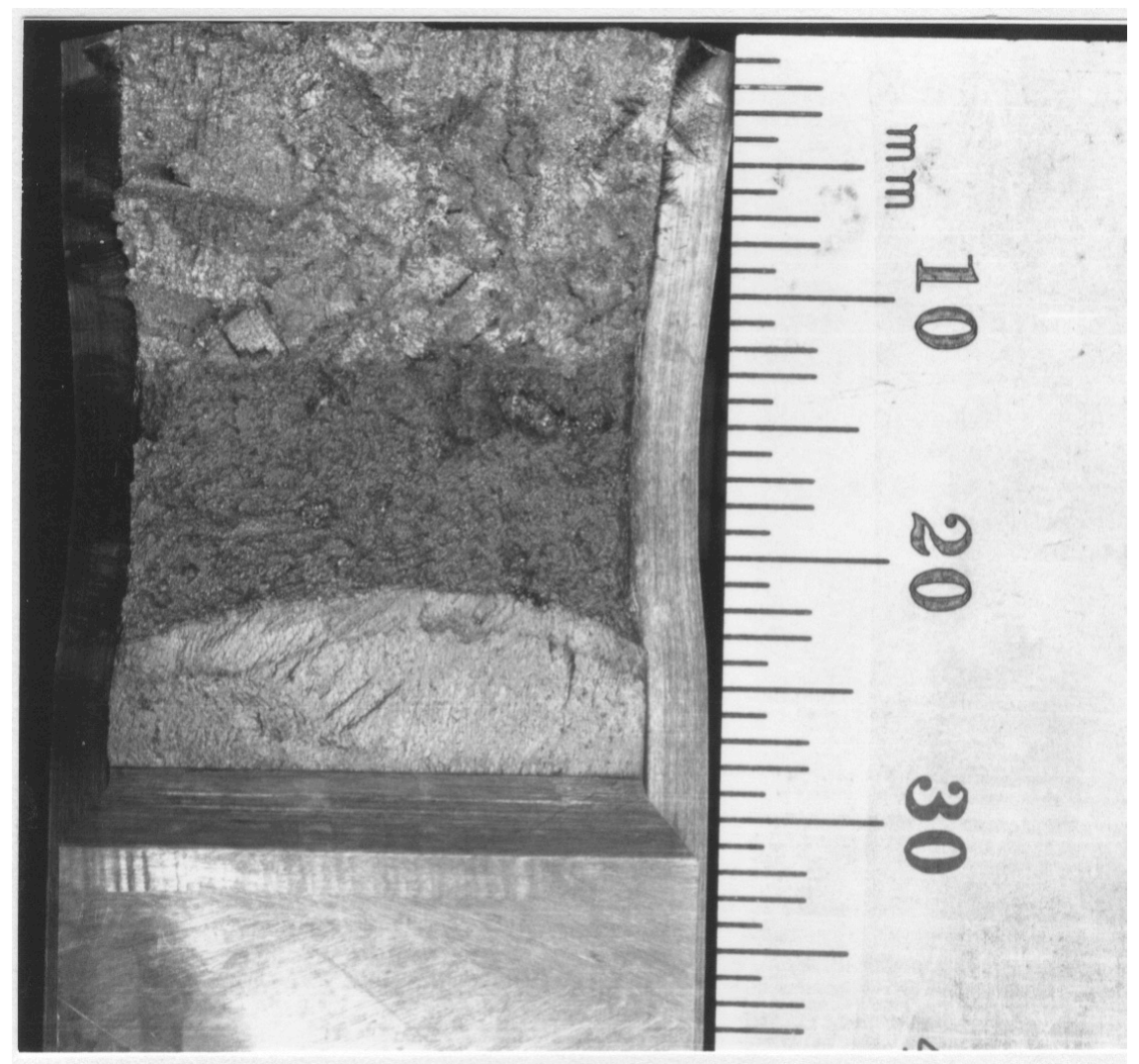

Figure C-11. Fracture surface of the cold-leg check valve CA4 tested at $290^{\circ} \mathrm{C}$ after $13 \mathrm{y}$ of service at $264^{\circ} \mathrm{C}$ 


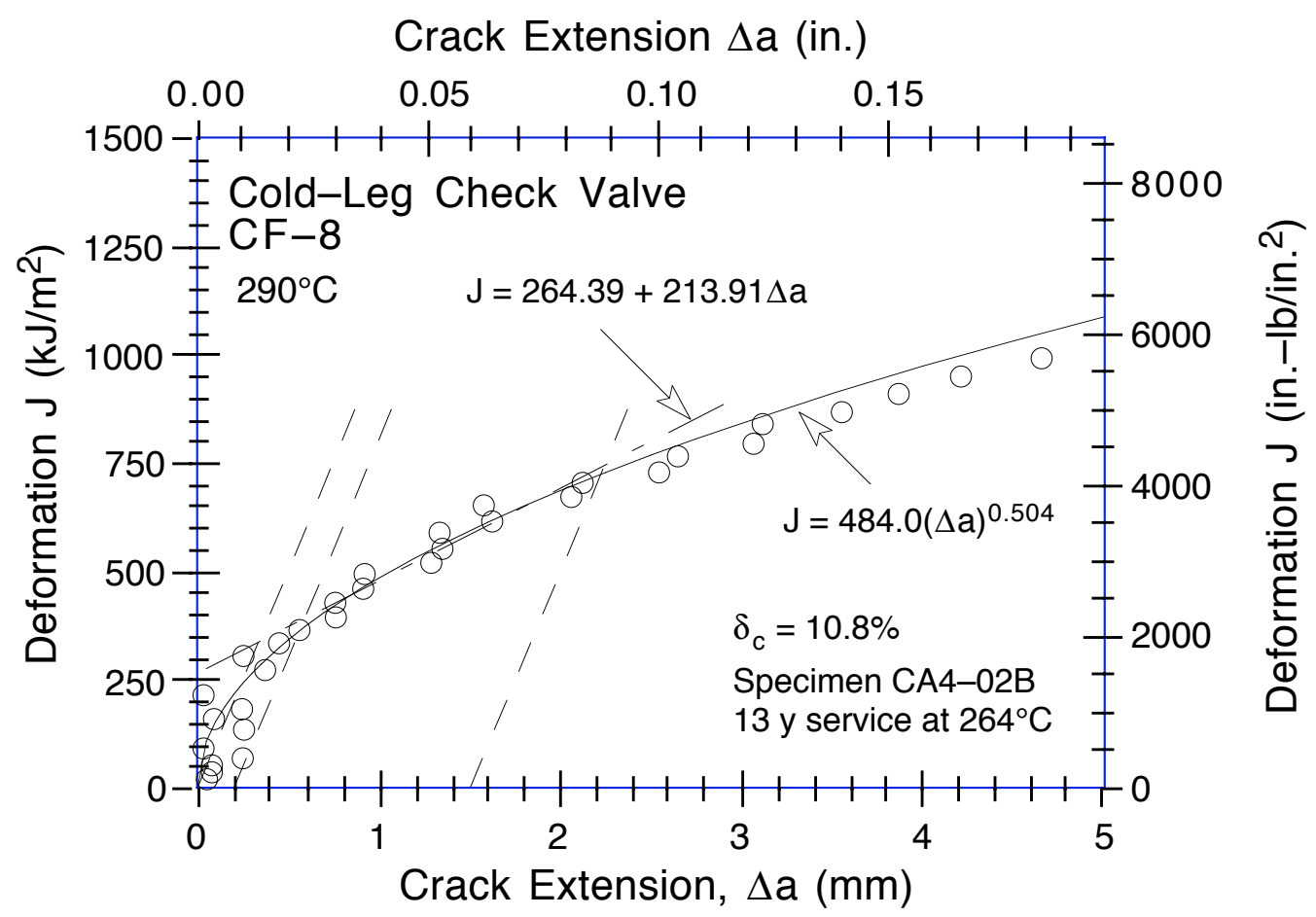

Figure C-12. Deformation J-R Curve at $290^{\circ} \mathrm{C}$ for the cold-leg check valve CA4 after $13 \mathrm{y}$ of service at $264^{\circ} \mathrm{C}$

Crack Extension $\Delta \mathrm{a}$ (in.)

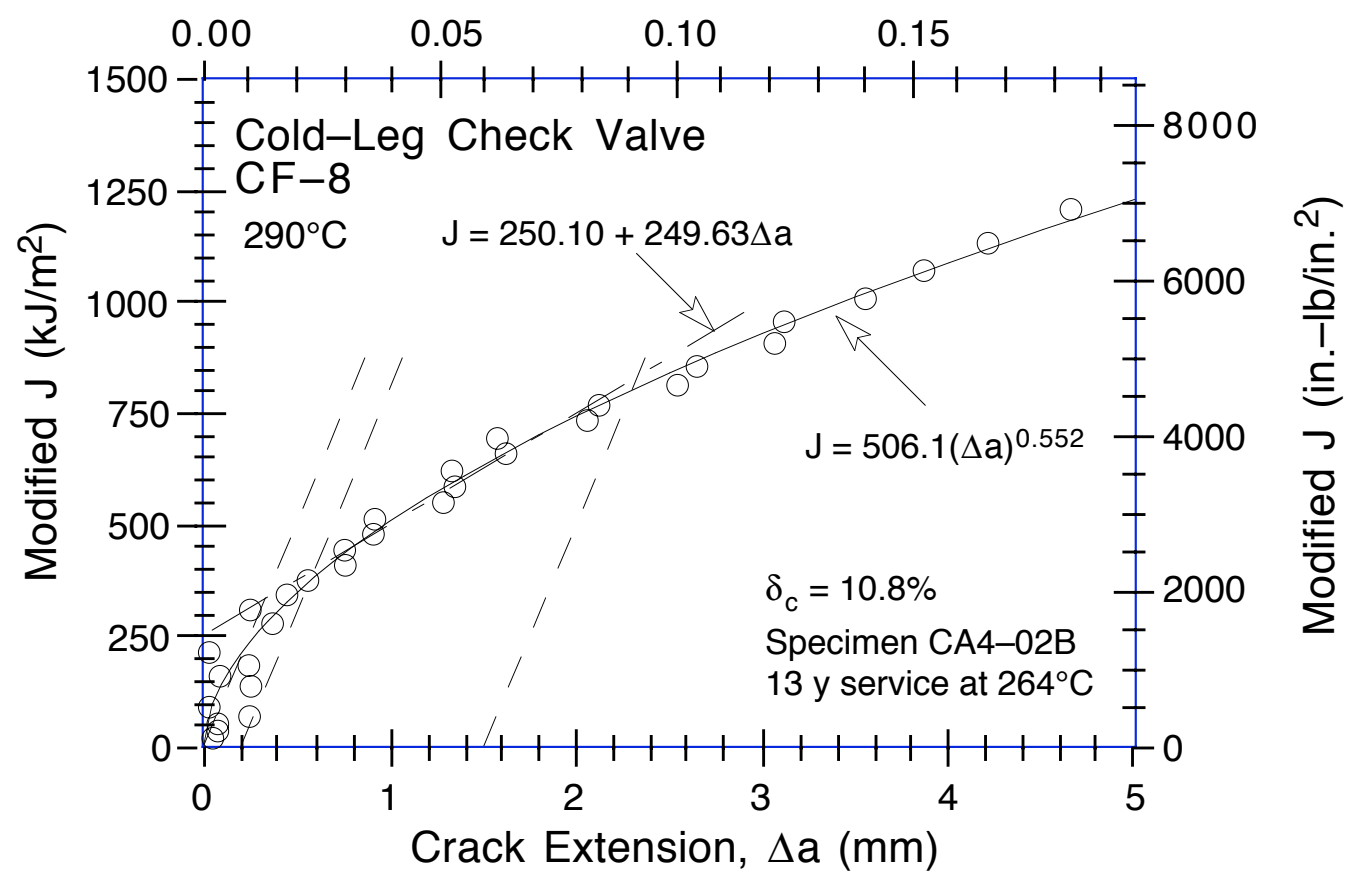

Figure C-13. Modified J-R Curve at $290^{\circ} \mathrm{C}$ for the cold-leg check valve CA4 after $13 \mathrm{y}$ of service at $264^{\circ} \mathrm{C}$ 
Table C-14. Test data for specimen MA1-01T

\begin{tabular}{|c|c|c|c|c|c|}
\hline \multicolumn{2}{|c|}{$\begin{array}{l}\text { Test Number } \\
\text { Material Type } \\
\text { Aging Temp. } \\
\text { Spec. Thickness } \\
\text { Spec. Width }\end{array}$} & $\begin{array}{l}: 0069 \\
: \mathrm{CF}-8 \\
: 281^{\circ} \mathrm{C} \\
: 25.37 \mathrm{~mm} \\
: 50.79 \mathrm{~mm}\end{array}$ & \multicolumn{2}{|c|}{$\begin{array}{l}\text { Test Temp. } \\
\text { Heat Number } \\
\text { Aging Time } \\
\text { Net Thickness } \\
\text { Flow Stress }\end{array}$} & $\begin{array}{l}: 25^{\circ} \mathrm{C} \\
: \mathrm{MA} 1 \\
: 113,000 \mathrm{~h} \\
: 20.35 \mathrm{~mm} \\
: 345.10 \mathrm{MPa}\end{array}$ \\
\hline $\begin{array}{c}\text { Unload } \\
\text { Number }\end{array}$ & $\begin{array}{c}J_{d} \\
\left(k J / m^{2}\right)\end{array}$ & $\begin{array}{c}J_{m} \\
\left(k J / m^{2}\right)\end{array}$ & $\begin{array}{c}\Delta \mathrm{a} \\
(\mathrm{m} \mathrm{m})\end{array}$ & $\begin{array}{l}\text { Load } \\
(\mathrm{kN})\end{array}$ & $\begin{array}{c}\text { Deflection } \\
(\mathrm{m} \mathrm{m})\end{array}$ \\
\hline 1 & 11.84 & 11.85 & 0.0128 & 16.366 & 0.252 \\
\hline 2 & 30.78 & 30.80 & 0.0281 & 19.915 & 0.455 \\
\hline 3 & 57.67 & 57.85 & 0.0881 & 21.696 & 0.705 \\
\hline 4 & 92.85 & 92.53 & -0.0170 & 23.015 & 1.008 \\
\hline 5 & 137.27 & 136.91 & -0.0232 & 24.195 & 1.369 \\
\hline 6 & 179.84 & 180.98 & 0.1295 & 25.167 & 1.709 \\
\hline 7 & 224.69 & 227.23 & 0.2399 & 25.867 & 2.060 \\
\hline 8 & 272.46 & 273.87 & 0.1670 & 26.653 & 2.408 \\
\hline 9 & 322.98 & 323.34 & 0.1101 & 27.361 & 2.760 \\
\hline 10 & 372.52 & 374.12 & 0.1676 & 27.868 & 3.111 \\
\hline 11 & 420.96 & 425.89 & 0.3026 & 28.473 & 3.461 \\
\hline 12 & 473.76 & 476.84 & 0.2362 & 29.060 & 3.809 \\
\hline 13 & 524.39 & 531.80 & 0.3755 & 29.563 & 4.160 \\
\hline 14 & 601.71 & 601.56 & 0.1634 & 30.241 & 4.624 \\
\hline 15 & 660.17 & 664.56 & 0.2786 & 30.627 & 5.006 \\
\hline 16 & 723.89 & 730.60 & 0.3323 & 31.034 & 5.418 \\
\hline 17 & 784.04 & 794.83 & 0.4188 & 31.560 & 5.808 \\
\hline 18 & 846.69 & 861.36 & 0.4945 & 31.986 & 6.207 \\
\hline 19 & 913.52 & 929.49 & 0.5182 & 32.232 & 6.611 \\
\hline 20 & 976.92 & 998.26 & 0.6084 & 32.650 & 7.008 \\
\hline 21 & 1039.11 & 1068.69 & 0.7378 & 33.060 & 7.410 \\
\hline 22 & 1109.17 & 1138.75 & 0.7378 & 33.359 & 7.814 \\
\hline 23 & 1170.34 & 1210.82 & 0.8887 & 33.456 & 8.211 \\
\hline 24 & 1232.78 & 1282.49 & $\begin{array}{l}1.0091 \\
\text {. }\end{array}$ & 33.459 & 8.612 \\
\hline 25 & 1300.03 & 1354.35 & 1.0660 & 33.766 & 9.012 \\
\hline 26 & 1367.20 & 1427.95 & 1.1412 & 33.958 & 9.413 \\
\hline 27 & 1423.26 & 1502.51 & 1.3473 & 33.789 & 9.811 \\
\hline 28 & 1486.29 & 1576.52 & $\begin{array}{l}1.4638 \\
1.4638\end{array}$ & 34.092 & 10.214 \\
\hline 29 & 1558.63 & 1649.70 & 1.4724 & 34.080 & 10.610 \\
\hline 30 & 1617.17 & 1727.00 & 1.6535 & 33.926 & 11.013 \\
\hline 31 & 1673.27 & 1802.79 & 1.8362 & 33.766 & 11.419 \\
\hline 32 & 1715.21 & 1877.10 & 2.1254 & 33.221 & 11.813 \\
\hline 33 & 1761.51 & 1951.61 & 2.3682 & 32.666 & 12.218 \\
\hline 34 & 1813.34 & 2023.95 & 2.5385 & 32.677 & 12.611 \\
\hline 35 & 1870.65 & 2098.52 & 2.6765 & 32.558 & 13.011 \\
\hline 36 & 1933.07 & 2193.93 & 2.9293 & 32.435 & 13.510 \\
\hline 37 & 2021.26 & 2286.51 & 2.9613 & 32.257 & 14.011 \\
\hline 38 & 2091.92 & 2405.15 & 3.2949 & 31.685 & 14.619 \\
\hline 39 & 2157.06 & 2514.90 & 3.5917 & 30.825 & 15.209 \\
\hline 40 & 2204.51 & 2625.72 & 3.9963 & 29.938 & 15.807 \\
\hline
\end{tabular}


Table C-15. Deformation $J_{I C}$ and $J-R$ curve results for specimen MA1-01T

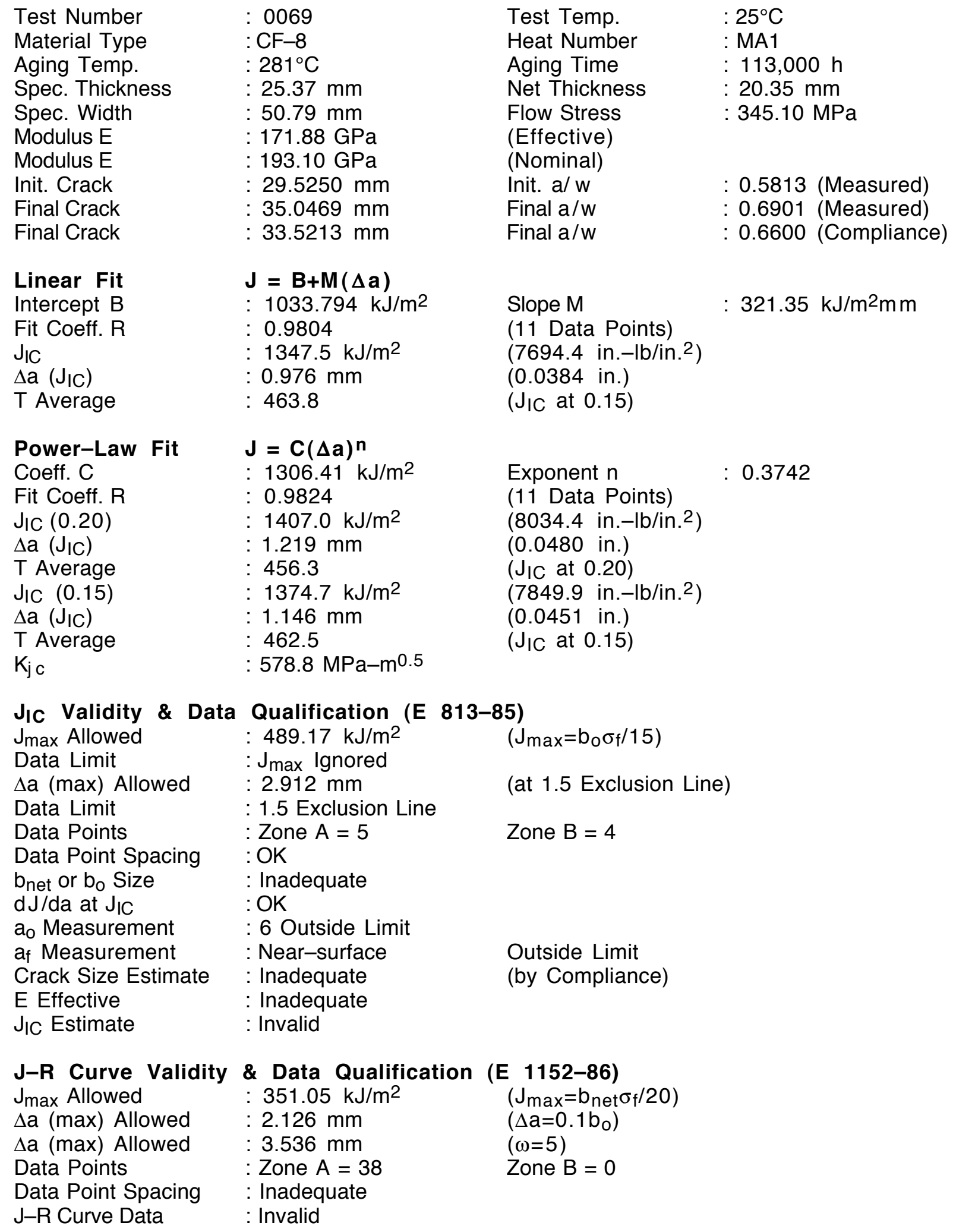


Table C-16. Modified JIC and $J-R$ curve results for specimen MA1-01T

\begin{tabular}{|c|c|c|c|}
\hline $\begin{array}{l}\text { Linear Fit } \\
\text { Intercept B } \\
\text { Fit Coeff. R } \\
\mathrm{J}_{\mathrm{IC}} \\
\Delta \mathrm{a}\left(\mathrm{J}_{\mathrm{IC}}\right) \\
\mathrm{T} \text { Average }\end{array}$ & $\begin{array}{l}\mathbf{J}=\mathbf{B}+\mathbf{M}(\Delta \mathbf{a}) \\
: 991.938 \mathrm{~kJ} / \mathrm{m}^{2} \\
: 0.9887 \\
: 1423.3 \mathrm{~kJ} / \mathrm{m}^{2} \\
: 1.031 \mathrm{~mm} \\
: 603.8\end{array}$ & $\begin{array}{l}\text { Slope M } \\
\text { (11 Data Points) } \\
\left(8127.6 \text { in.-lb/in. }{ }^{2}\right) \\
(0.0406 \text { in.) } \\
\left(J_{I C} \text { at } 0.15\right)\end{array}$ & : 418.39 \\
\hline $\begin{array}{l}\text { Power-Law Fit } \\
\text { Coeff. C } \\
\text { Fit Coeff. R } \\
\mathrm{J}_{\mathrm{IC}}(0.20) \\
\Delta \mathrm{a}\left(\mathrm{J}_{\mathrm{IC}}\right) \\
\mathrm{T} \text { Average } \\
\mathrm{J}_{\mathrm{IC}}(0.15) \\
\Delta \mathrm{a}\left(\mathrm{J}_{\mathrm{IC}}\right) \\
\mathrm{T}_{\mathrm{C}} \text { Average } \\
\mathrm{K}_{\mathrm{j} \mathrm{c}}\end{array}$ & 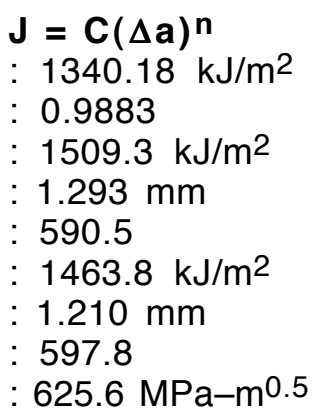 & $\begin{array}{l}\text { Exponent } n \\
(11 \text { Data Points) } \\
\left(8618.4 \text { in.-lb/in. }{ }^{2}\right) \\
(0.0509 \text { in. }) \\
\left(\mathrm{J}_{\mathrm{IC}} \text { at } 0.20\right) \\
\left(8358.4 \text { in. }-\mathrm{lb} / \text { in. }^{2}\right) \\
(0.0477 \text { in.) } \\
\left(\mathrm{J}_{\mathrm{IC}} \text { at } 0.15\right)\end{array}$ & 0.4620 \\
\hline
\end{tabular}

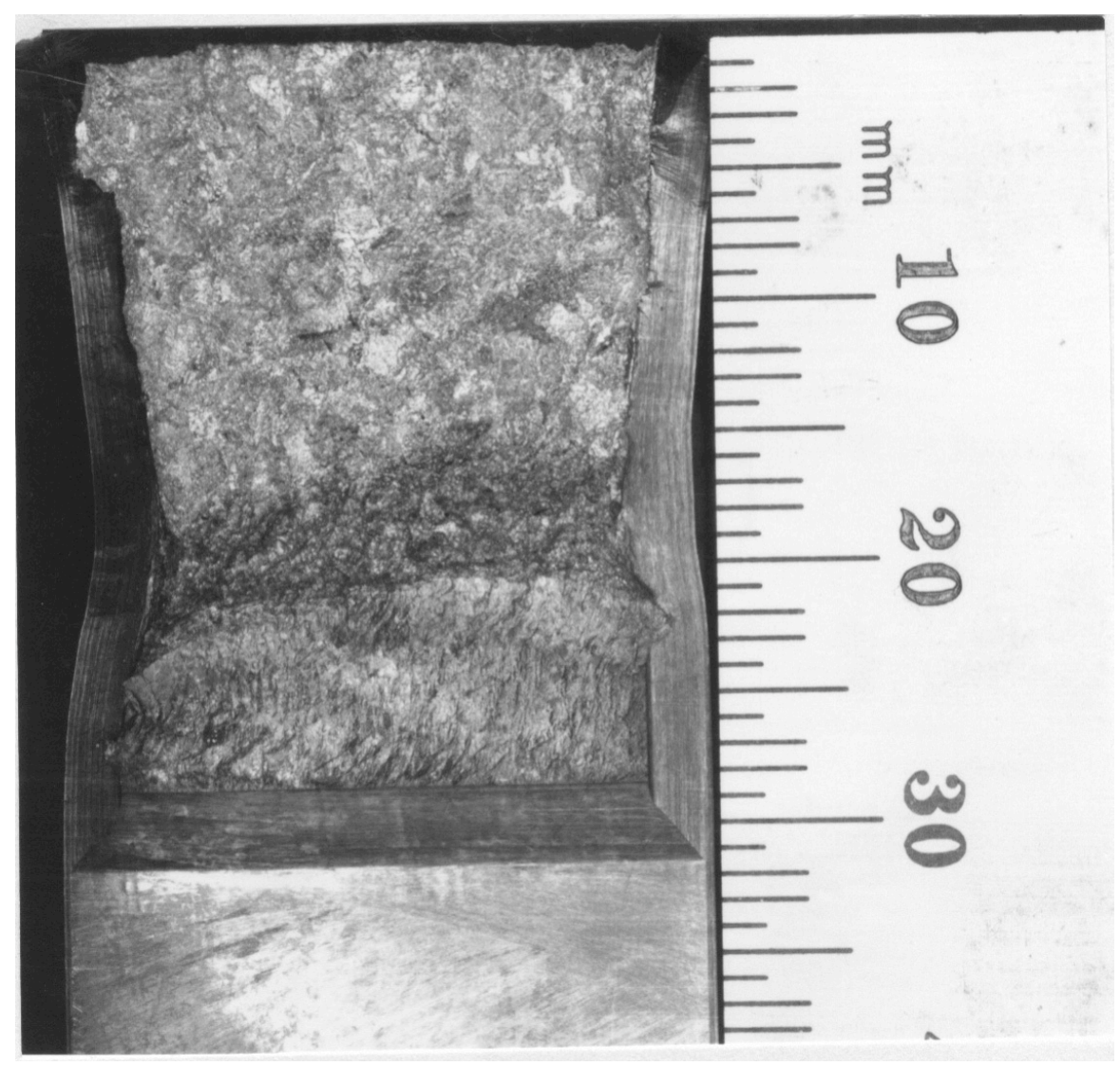

Figure C-14. Fracture surface of the hot-leg main shutoff valve MA1 tested at room temperature after $13 \mathrm{y}$ of service at $281^{\circ} \mathrm{C}$ 


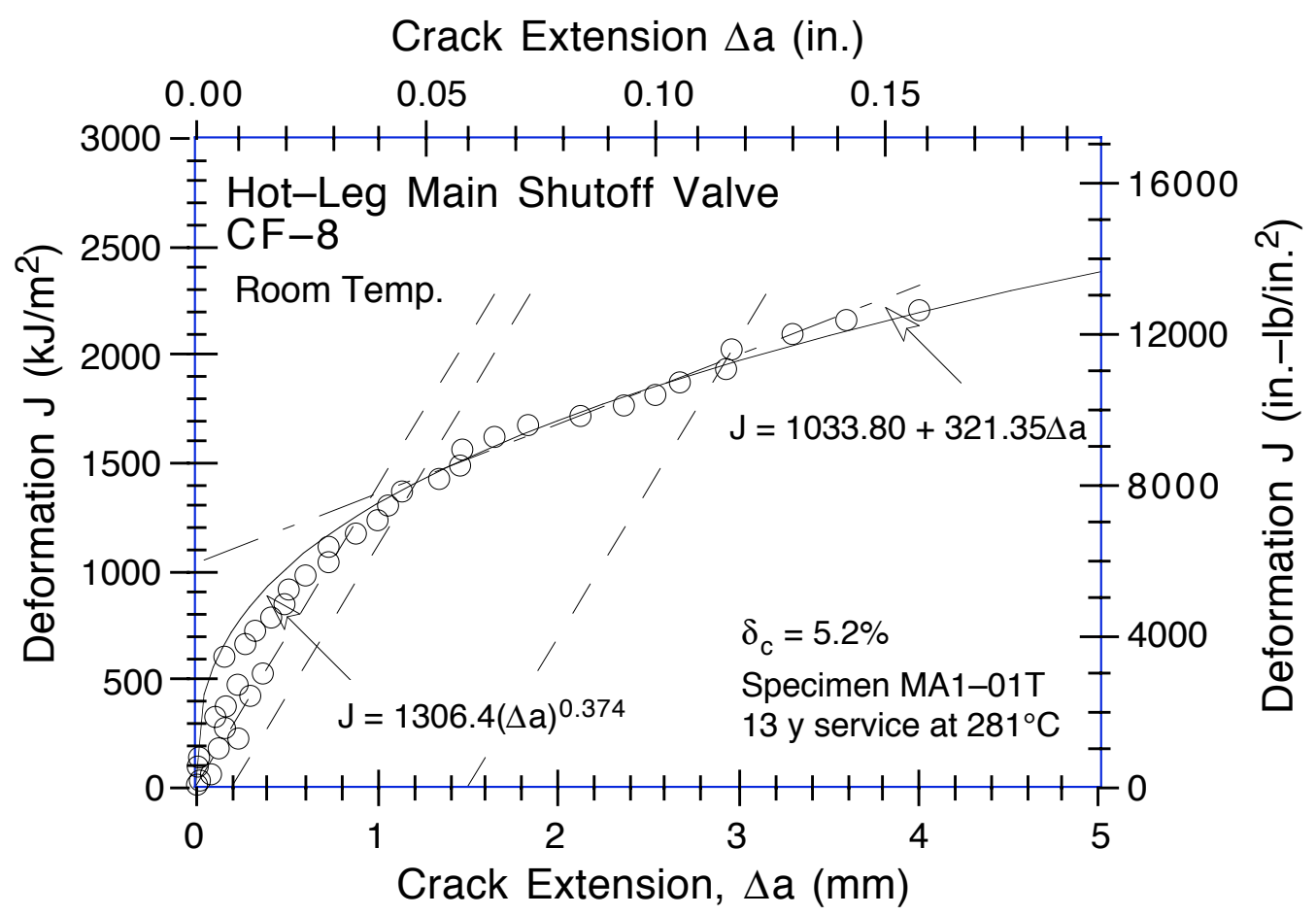

Figure $C-15$. Deformation $\mathrm{J}-R$ Curve at room temperature for hot-leg main shutoff valve MA1 after $13 y$ of service at $281^{\circ} \mathrm{C}$

Crack Extension $\Delta$ a (in.)

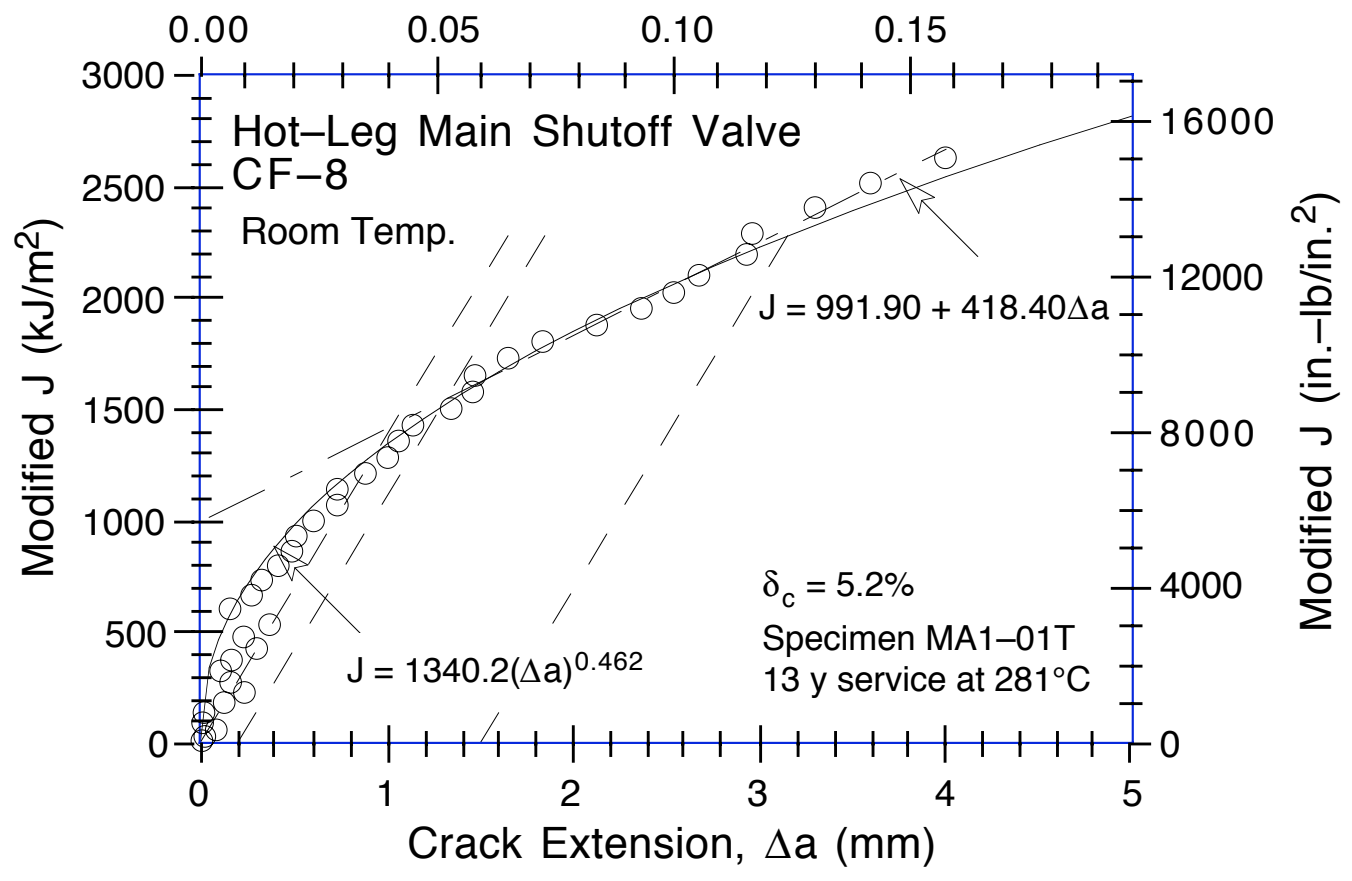

Figure $C-16$. Modified $J-R$ Curve at room temperature for hot-leg main shutoff valve MA1 after $13 \mathrm{y}$ of service at $281^{\circ} \mathrm{C}$ 
Table C-17. Test data for specimen MA1-01B

\begin{tabular}{|c|c|c|c|c|c|}
\hline $\begin{array}{l}\text { Test Nun } \\
\text { Material } \\
\text { Aging Te } \\
\text { Spec. Th } \\
\text { Spec. Wi }\end{array}$ & $\begin{array}{l}\text { ber } \\
\text { ype } \\
\text { ip. } \\
\text { kness } \\
\text { th }\end{array}$ & $\mathrm{mm}$ & $\begin{array}{l}\text { Test } \\
\text { Heat } \\
\text { Aging } \\
\text { Net. } \\
\text { Flow }\end{array}$ & ss & $\begin{array}{l}300 \mathrm{~h} \\
3 \mathrm{~mm} \\
0 \mathrm{MPa}\end{array}$ \\
\hline $\begin{array}{c}\text { Unload } \\
\text { Number }\end{array}$ & $\begin{array}{c}J_{d} \\
\left(k J / m^{2}\right)\end{array}$ & $\begin{array}{c}J_{m} \\
\left(k J / m^{2}\right)\end{array}$ & $\begin{array}{c}\Delta \mathrm{a} \\
(\mathrm{mm})\end{array}$ & $\begin{array}{l}\text { Load } \\
(\mathrm{kN})\end{array}$ & $\begin{array}{c}\text { Deflection } \\
(\mathrm{m} \mathrm{m})\end{array}$ \\
\hline 1 & 9.39 & 9.38 & -0.0214 & 11823 & 0.254 \\
\hline 2 & 26.52 & 26.36 & -0.1457 & 13.772 & 0.508 \\
\hline 3 & 49.22 & 49.79 & 0.1382 & 14.947 & 0.808 \\
\hline 4 & 72.96 & 73.75 & 0.1933 & 15.643 & 1.109 \\
\hline 5 & 98.15 & 99.05 & 0.2142 & 16.339 & 1.409 \\
\hline 6 & 129.56 & 129.63 & 0.1026 & 16.977 & 1.759 \\
\hline 7 & 161.91 & 161.65 & 0.0677 & 17.485 & 2.109 \\
\hline 8 & 199.41 & 199.61 & 0.1067 & 18.030 & 2.510 \\
\hline 9 & 236.99 & 238.51 & 0.1997 & 18.655 & 2.909 \\
\hline 10 & 277.42 & 278.16 & 0.1535 & 19.138 & 3.309 \\
\hline 11 & 316.18 & 320.03 & 0.3158 & 19.646 & 3.710 \\
\hline 12 & 359.11 & 361.24 & 0.2369 & 20.093 & 4.108 \\
\hline 13 & 398.27 & 405.57 & 0.4489 & 20.452 & 4.508 \\
\hline 14 & 433.97 & 436.72 & 0.2768 & 20.754 & 4.805 \\
\hline 15 & 466.85 & 471.89 & 0.3568 & 21.003 & 5.111 \\
\hline 16 & 495.41 & 506.75 & 0.5626 & 21.339 & 5.414 \\
\hline 17 & 535.57 & 538.65 & 0.3118 & 21.508 & 5.709 \\
\hline 18 & 562.16 & 576.16 & 0.6243 & 21.654 & 6.013 \\
\hline 19 & 615.62 & 620.49 & 0.3843 & 21.970 & 6.413 \\
\hline 20 & 650.45 & 670.24 & 0.7502 & 22.151 & 6.809 \\
\hline 21 & 690.95 & 717.47 & 0.9047 & 22.282 & 7.209 \\
\hline 22 & 735.36 & 765.99 & 0.9930 & 22.500 & 7.608 \\
\hline 23 & 780.98 & 822.66 & 1.2140 & 22.620 & 8.059 \\
\hline 24 & 838.06 & $\begin{array}{l}878.38 \\
878\end{array}$ & 1.1886 & 22.737 & 8.513 \\
\hline 25 & 889.51 & 942.46 & 1.4082 & 22.542 & 9.010 \\
\hline 26 & 944.76 & 1004.02 & 1.5108 & 21.984 & 9.508 \\
\hline 27 & 980.62 & 1080.44 & 2.1305 & 21.605 & 10.112 \\
\hline 28 & 1012.14 & 1153.63 & 2.7324 & 21.232 & 10.709 \\
\hline 29 & 1079.84 & 1224.93 & 2.7809 & 20.460 & 11.309 \\
\hline 30 & 1096.91 & 1299.61 & 3.5203 & 19.713 & 11.907 \\
\hline 31 & 1124.54 & 1369.97 & 4.0426 & 19.155 & 12.510 \\
\hline 32 & 1173.30 & 1440.84 & 4.2982 & 18.779 & 13.111 \\
\hline 33 & 1215.49 & 1513.82 & 4.6361 & 18.569 & 13.710 \\
\hline 34 & 1265.56 & 1586.37 & 4.8704 & 18.530 & 14.310 \\
\hline $\begin{array}{l}04 \\
35\end{array}$ & 1313.76 & 1660.67 & $\begin{array}{l}5.1287 \\
5.124\end{array}$ & $\begin{array}{l}18.154 \\
\end{array}$ & $\begin{array}{l}14.912 \\
14.90\end{array}$ \\
\hline 36 & 1355.27 & 1733.76 & 5.4269 & 17.716 & 15.511 \\
\hline 37 & 1379.60 & 1806.70 & 5.8673 & 17.041 & 16.113 \\
\hline 38 & 1393.61 & 1877.15 & 6.3600 & 16.503 & 16.714 \\
\hline
\end{tabular}


Table $C-18$. Deformation $J_{I C}$ and $J-R$ curve results for specimen MA1-01B

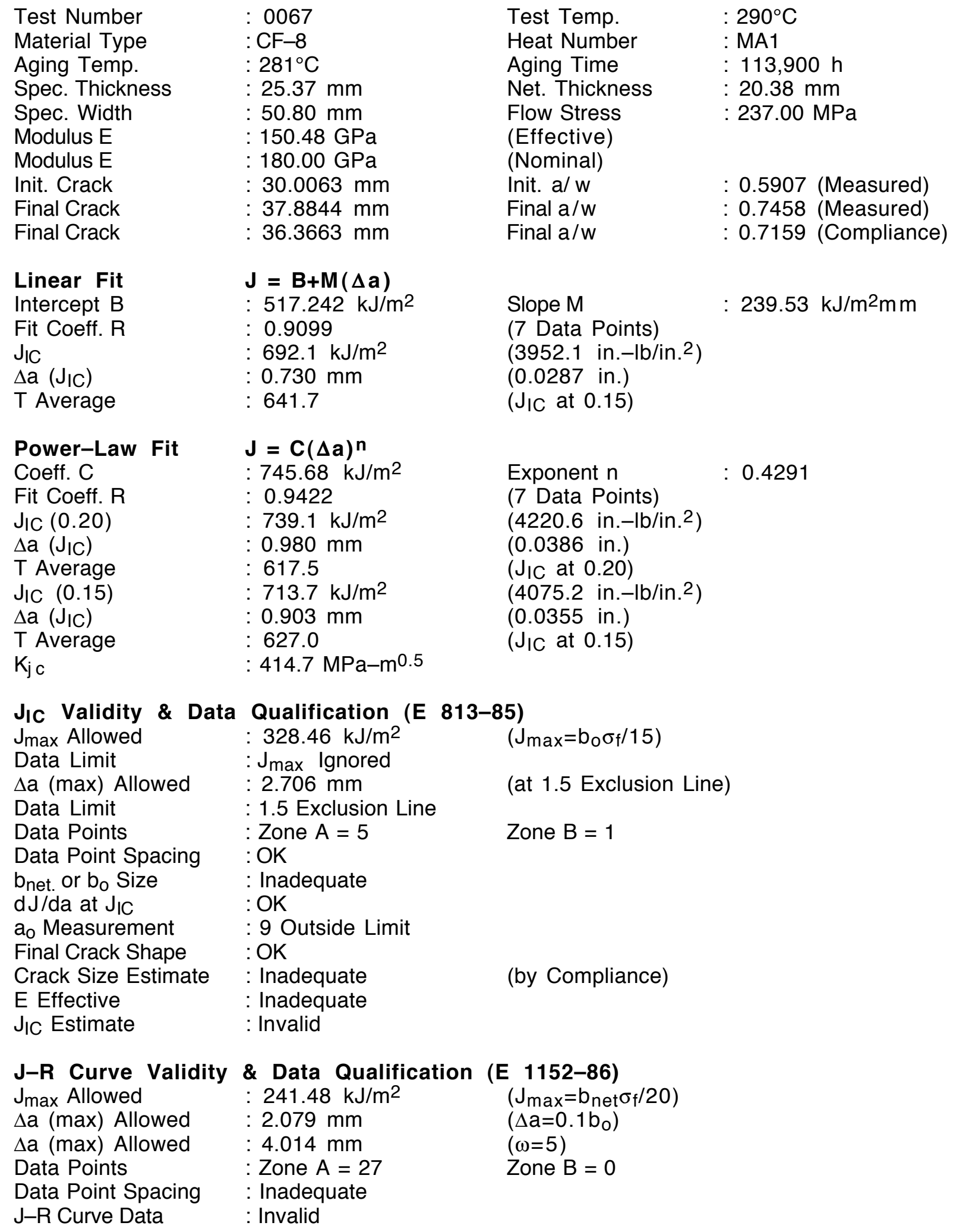


Table $C-19$. Modified J/C and J-R curve results for specimen MA-01B

\begin{tabular}{|c|c|c|c|}
\hline $\begin{array}{l}\text { Linear Fit } \\
\text { Intercept B } \\
\text { Fit Coeff. R } \\
\mathrm{J}_{\mathrm{IC}} \\
\Delta \mathrm{a}\left(\mathrm{J}_{\mathrm{IC}}\right) \\
\mathrm{T} \text { Average }\end{array}$ & $\begin{array}{l}\mathbf{J}=\mathbf{B}+\mathbf{M}(\Delta \mathbf{a}) \\
: 573.082 \mathrm{~kJ} / \mathrm{m}^{2} \\
: 0.9658 \\
: 768.6 \mathrm{~kJ} / \mathrm{m}^{2} \\
: 0.811 \mathrm{~mm} \\
: 646.1\end{array}$ & $\begin{array}{l}\text { Slope } M \\
\text { (7 Data Points) } \\
\left(4388.9 \text { in. }-\mathrm{lb} / \mathrm{in}^{2}\right) \\
(0.0319 \text { in. }) \\
\left(\mathrm{J}_{\mathrm{IC}} \text { at } 0.15\right)\end{array}$ & $: 241.16 \mathrm{~kJ} / \mathrm{m}^{2} \mathrm{~mm}$ \\
\hline $\begin{array}{l}\text { Power-Law Fit } \\
\text { Coeff. C } \\
\text { Fit Coeff. R } \\
\mathrm{J}_{\mathrm{IC}}(0.20) \\
\Delta \mathrm{a}\left(\mathrm{J}_{\mathrm{IC}}\right) \\
\text { T Average } \\
\mathrm{J}_{\mathrm{IC}}(0.15) \\
\Delta \mathrm{a}\left(\mathrm{J}_{\mathrm{IC}}\right) \\
\mathrm{T}_{\mathrm{C}} \text { Average } \\
\mathrm{K}_{\mathrm{j}} \mathrm{c}\end{array}$ & $\begin{array}{l}\mathbf{J}=\mathbf{C}(\Delta \mathbf{a})^{\mathbf{n}} \\
: 791.71 \mathrm{~kJ} / \mathrm{m}^{2} \\
: 0.9735 \\
: 810.5 \mathrm{~kJ} / \mathrm{m}^{2} \\
: 1.055 \mathrm{~mm} \\
: 654.3 \\
: 783.5 \mathrm{~kJ} / \mathrm{m}^{2} \\
: 0.976 \mathrm{~mm} \\
: 663.7 \\
: 433.0 \mathrm{MPa}-\mathrm{m}^{0.5}\end{array}$ & $\begin{array}{l}\text { Exponent } \mathrm{n} \\
\text { (7 Data Points) } \\
\left(4628.1 \text { in.--lb/in. }{ }^{2}\right) \\
(0.0415 \text { in.) } \\
\left(\mathrm{J}_{\mathrm{IC}} \text { at } 0.20\right) \\
\left(4473.9 \text { in.-lb/in. }{ }^{2}\right) \\
(0.0384 \text { in.) } \\
\left(\mathrm{J}_{\mathrm{IC}} \text { at } 0.15\right)\end{array}$ & 0.4383 \\
\hline
\end{tabular}

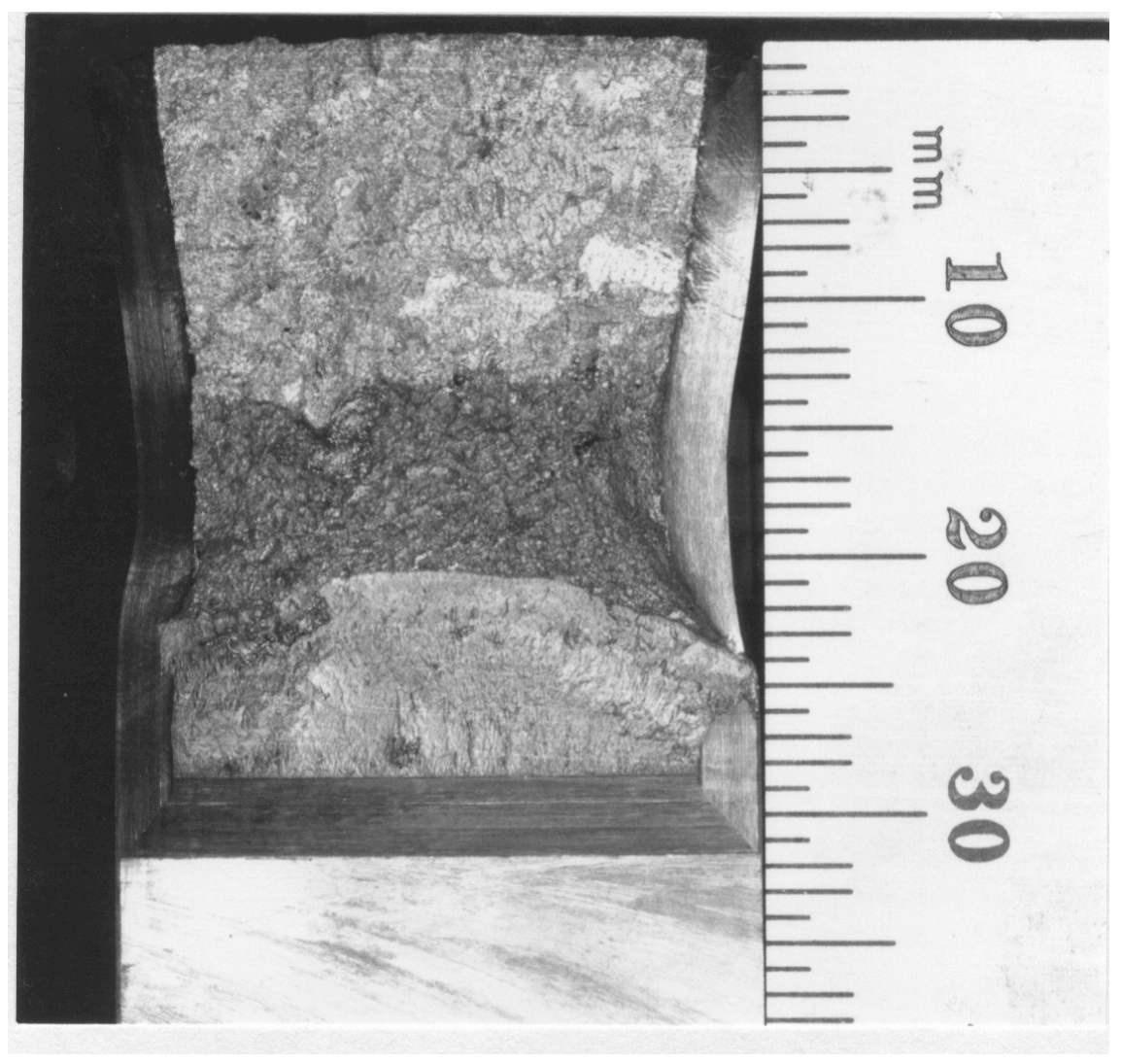

Figure $C-17$. Fracture surface of the hot-leg main shutoff valve MA1 tested at $290^{\circ} \mathrm{C}$ after $13 \mathrm{y}$ of service at $281^{\circ} \mathrm{C}$ 


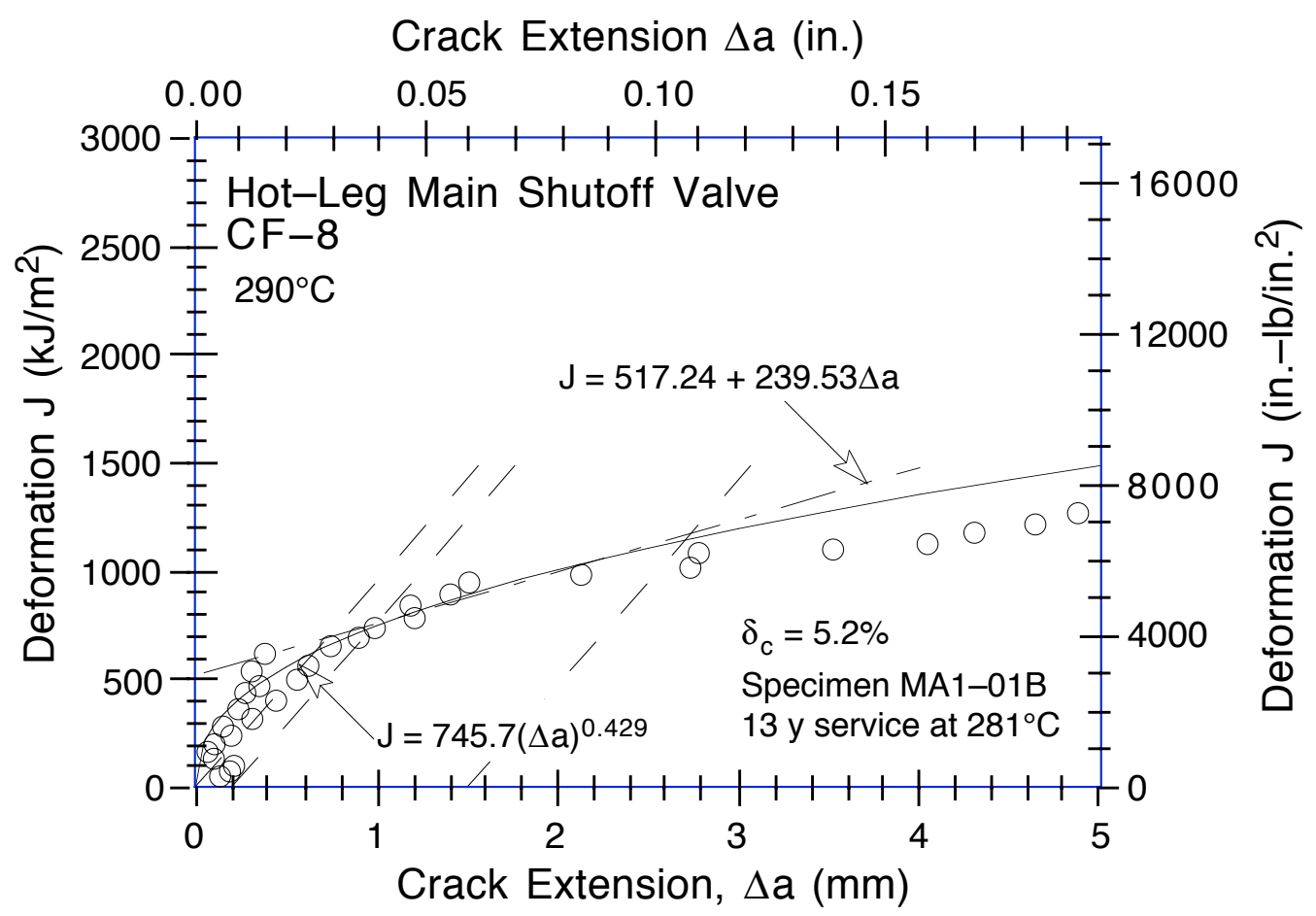

Figure C-18. Deformation J-R Curve at $290^{\circ} \mathrm{C}$ for hot-leg main shutoff valve MA1 after $13 \mathrm{y}$ of service at $281^{\circ} \mathrm{C}$

Crack Extension $\Delta$ a (in.)

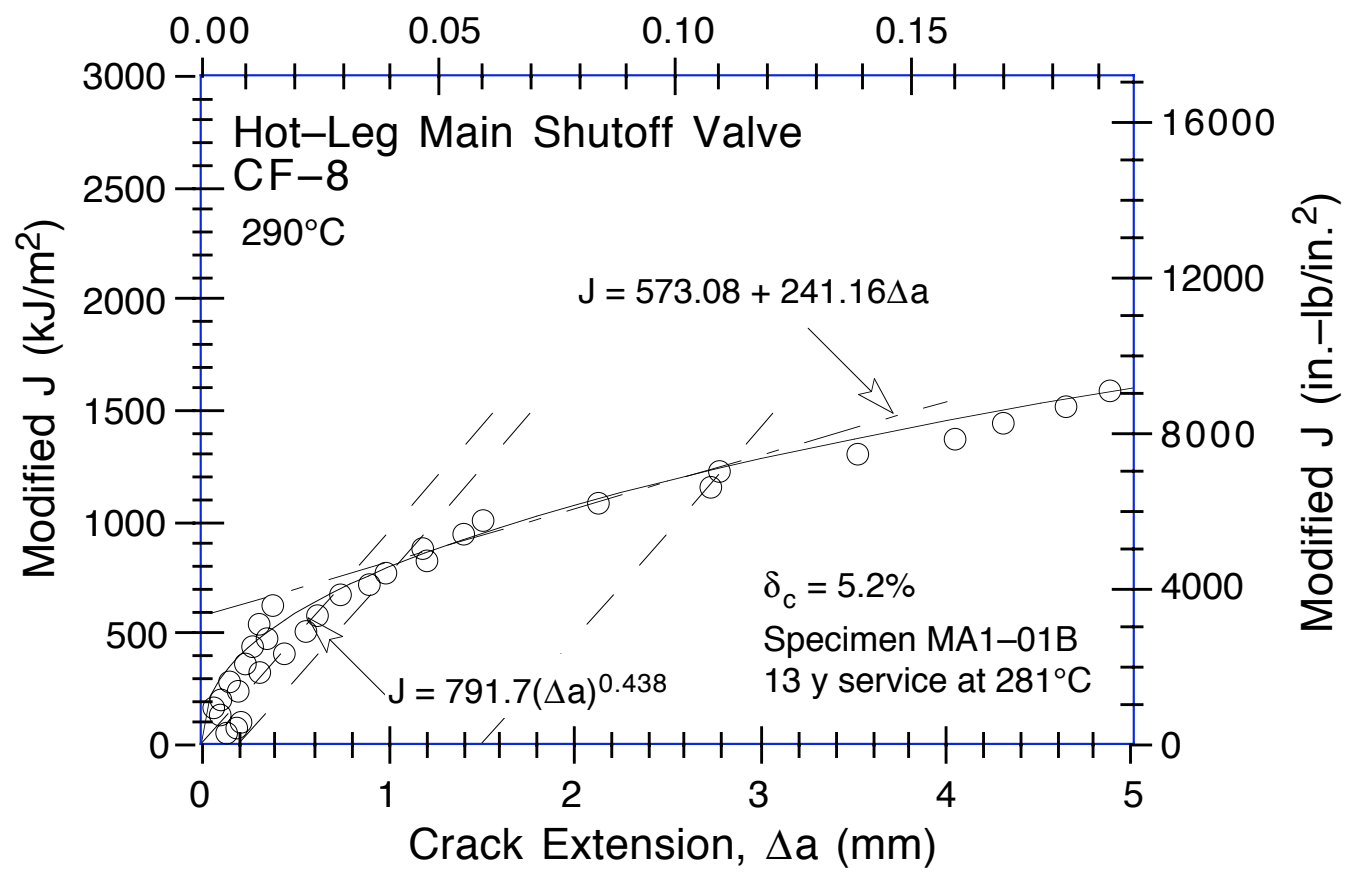

Figure C-19. Modified J-R Curve at $290^{\circ} \mathrm{C}$ for hot-leg main shutoff valve MA1 after $13 \mathrm{y}$ of service at $281^{\circ} \mathrm{C}$ 


\begin{tabular}{|c|c|c|c|c|c|}
\hline \multicolumn{2}{|c|}{$\begin{array}{l}\text { Test Number } \\
\text { Material Type } \\
\text { Aging Temp. } \\
\text { Spec. Thickness } \\
\text { Spec. Width }\end{array}$} & $\begin{array}{l}: 0083 \\
: C F-8 \\
: 25^{\circ} \mathrm{C} \\
: 25.34 \mathrm{~mm} \\
: 50.81 \mathrm{~mm}\end{array}$ & \multicolumn{2}{|c|}{$\begin{array}{l}\text { Test Temp. } \\
\text { Heat Number } \\
\text { Aging Time } \\
\text { Net Thickness } \\
\text { Flow Stress }\end{array}$} & $\begin{array}{l}: 25^{\circ} \mathrm{C} \\
: \text { MA9 } \\
: 0 \mathrm{~h} \\
: 20.27 \mathrm{~mm} \\
: 366.00 \mathrm{MPa}\end{array}$ \\
\hline $\begin{array}{c}\text { Unload } \\
\text { Number }\end{array}$ & $\begin{array}{c}J_{d} \\
\left(k J / m^{2}\right)\end{array}$ & $\begin{array}{c}J_{m} \\
\left(k J / m^{2}\right)\end{array}$ & $\begin{array}{c}\Delta \mathrm{a} \\
(\mathrm{m} \mathrm{m})\end{array}$ & $\begin{array}{l}\text { Load } \\
(\mathrm{kN})\end{array}$ & $\begin{array}{c}\text { Deflection } \\
(\mathrm{m} \mathrm{m})\end{array}$ \\
\hline 1 & 16.82 & 16.83 & 0.0255 & 19.187 & 0.304 \\
\hline 2 & 46.22 & 46.21 & 0.0167 & 22.320 & 0.607 \\
\hline 3 & 78.35 & 78.63 & 0.0964 & 23.812 & 0.908 \\
\hline 4 & 112.35 & 113.19 & 0.1986 & 24.799 & 1.214 \\
\hline 5 & 147.36 & 147.02 & 0.0393 & 25.494 & 1.510 \\
\hline 6 & 184.39 & 184.23 & 0.0571 & 26.045 & 1.816 \\
\hline 7 & 219.75 & 220.54 & 0.1414 & 26.670 & 2.110 \\
\hline 8 & 270.35 & 270.76 & 0.1141 & 27.718 & 2.510 \\
\hline 9 & 321.69 & 323.39 & 0.1902 & 28.289 & 2.913 \\
\hline 10 & 386.89 & 389.70 & 0.2442 & 29.109 & 3.409 \\
\hline 11 & 455.87 & 458.36 & 0.2312 & 29.822 & 3.909 \\
\hline 12 & 529.20 & 528.65 & 0.1244 & 30.726 & 4.410 \\
\hline 13 & 596.68 & 602.53 & 0.3218 & 31.378 & 4.910 \\
\hline 14 & 668.64 & 676.56 & 0.3786 & 32.067 & 5.413 \\
\hline 15 & 748.51 & 752.16 & 0.2739 & 32.792 & 5.916 \\
\hline 16 & 820.70 & 830.46 & 0.4098 & 33.497 & 6.412 \\
\hline 17 & 899.51 & 908.72 & 0.3985 & 34.290 & 6.911 \\
\hline 18 & 977.70 & 990.46 & 0.4645 & 34.755 & 7.414 \\
\hline 19 & 1059.12 & 1071.90 & 0.4647 & 35.147 & 7.911 \\
\hline 20 & 1137.47 & 1157.32 & 0.5769 & 35.540 & 8.418 \\
\hline 21 & 1214.16 & 1240.75 & 0.6763 & 36.110 & 8.910 \\
\hline 22 & 1307.18 & 1326.67 & 0.5789 & 36.579 & 9.418 \\
\hline 23 & 1382.19 & 1413.97 & 0.7377 & 36.800 & 9.909 \\
\hline 24 & 1459.66 & 1501.96 & 0.8660 & 37.299 & 10.410 \\
\hline 25 & 1523.38 & 1572.78 & 0.9487 & 37.677 & 10.809 \\
\hline 26 & 1612.05 & 1692.10 & 1.2824 & 37.832 & 11.459 \\
\hline 27 & 1724.81 & 1788.62 & 1.1166 & 38.341 & 12.009 \\
\hline 28 & 1813.65 & 1905.24 & 1.3840 & 38.224 & 12.619 \\
\hline 29 & 1886.33 & 2015.73 & 1.7299 & 38.100 & 13.212 \\
\hline 30 & 1969.53 & 2127.08 & 1.9742 & 37.492 & 13.815 \\
\hline 31 & 2041.85 & 2243.89 & 2.3420 & 36.888 & 14.440 \\
\hline 32 & 2110.11 & 2349.54 & 2.6381 & 36.658 & 15.014 \\
\hline 33 & 2161.14 & 2460.99 & 3.0974 & 35.475 & 15.614 \\
\hline
\end{tabular}


Table C-21. Deformation J/C and J-R curve results for specimen MA9-01/

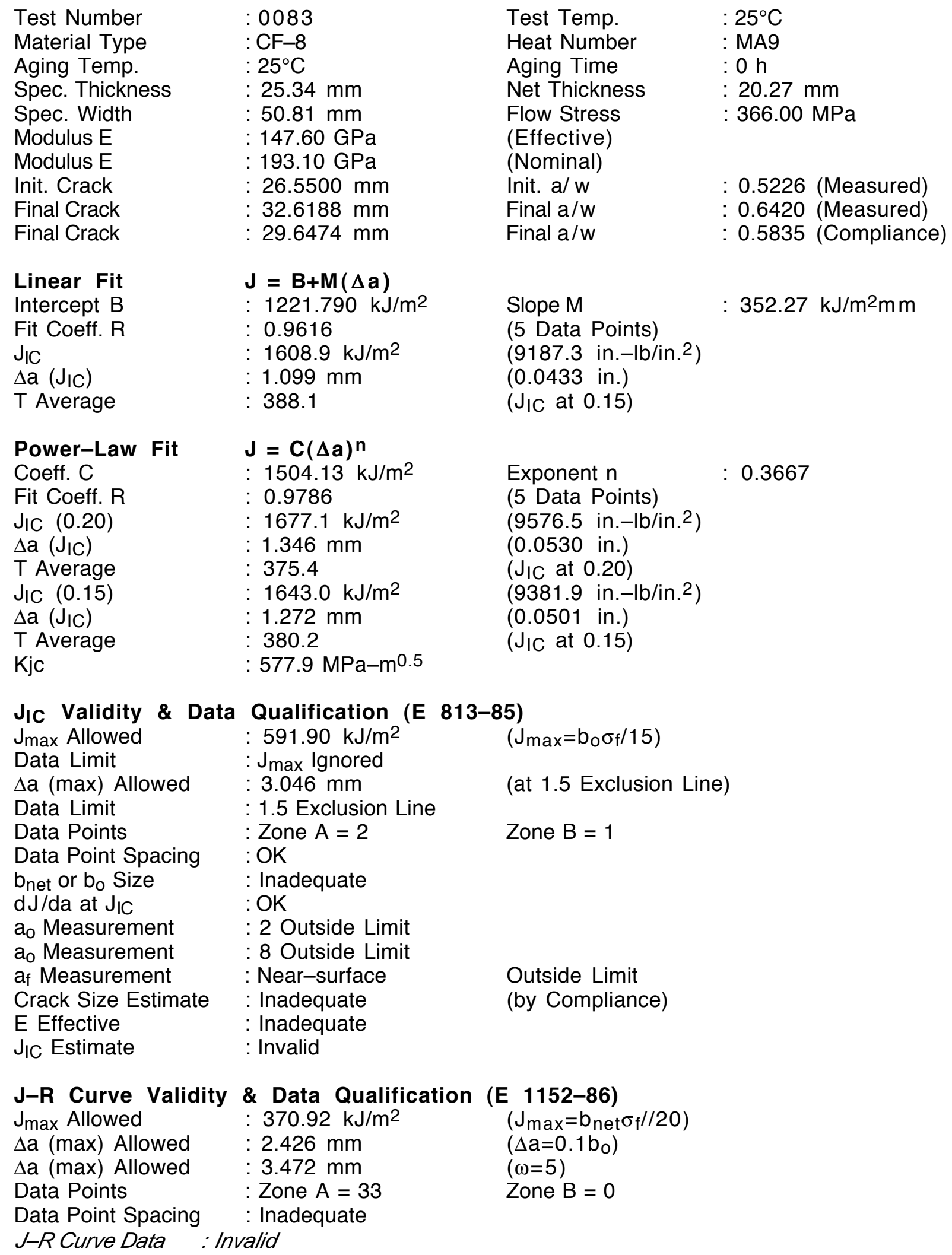


Table C-22. Modified J/C and J-R curve results for specimen MA9-01/

\begin{tabular}{|c|c|c|c|}
\hline $\begin{array}{l}\text { Linear Fit } \\
\text { Intercept B } \\
\text { Fit Coeff. R } \\
\mathrm{J}_{\mathrm{IC}} \\
\Delta \mathrm{a}\left(\mathrm{J}_{\mathrm{IC}}\right) \\
\mathrm{T} \text { Average }\end{array}$ & $\begin{array}{l}\mathbf{J}=\mathbf{B}+\mathbf{M}(\Delta \mathbf{a}) \\
: 1475.937 \mathrm{~kJ} / \mathrm{m}^{2} \\
: 0.9946 \\
: 1895.5 \mathrm{~kJ} / \mathrm{m}^{2} \\
: 1.295 \mathrm{~mm} \\
: 357.0\end{array}$ & $\begin{array}{l}\text { Slope } M \\
\text { (5 Data Points) } \\
\left(10823.4 \text { in.-lb/in. }{ }^{2}\right) \\
(0.0510 \text { in. }) \\
\left(J_{I C} \text { at } 0.15\right)\end{array}$ & : $324.02 \mathrm{~kJ} / \mathrm{m}^{2} \mathrm{~mm}$ \\
\hline 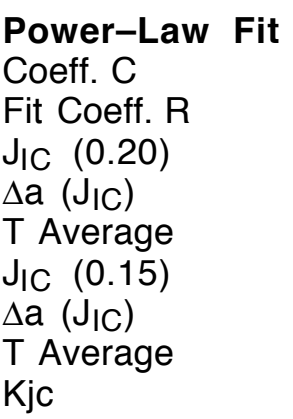 & $\begin{array}{l}\mathbf{J}=\mathbf{C}(\Delta \mathbf{a})^{\mathbf{n}} \\
: 1678.28 \mathrm{~kJ} / \mathrm{m}^{2} \\
: 0.9985 \\
: 1938.5 \mathrm{~kJ} / \mathrm{m}^{2} \\
: 1.524 \mathrm{~mm} \\
: 364.1 \\
: 1906.9 \mathrm{~kJ} / \mathrm{m}^{2} \\
: 1.453 \mathrm{~mm} \\
: 368.5 \\
: 607.5 \mathrm{MPa}-\mathrm{m}^{0.5}\end{array}$ & $\begin{array}{l}\text { Exponent } n \\
(5 \text { Data Points }) \\
\left(11069.5 \text { in.-lb/in. }{ }^{2}\right) \\
(0.0600 \text { in. }) \\
\left(J_{I C} \text { at } 0.20\right) \\
\left(10888.7 \text { in.-lb/in. }{ }^{2}\right) \\
(0.0572 \text { in. }) \\
\left(J_{I C} \text { at } 0.15\right)\end{array}$ & 0.3421 \\
\hline
\end{tabular}

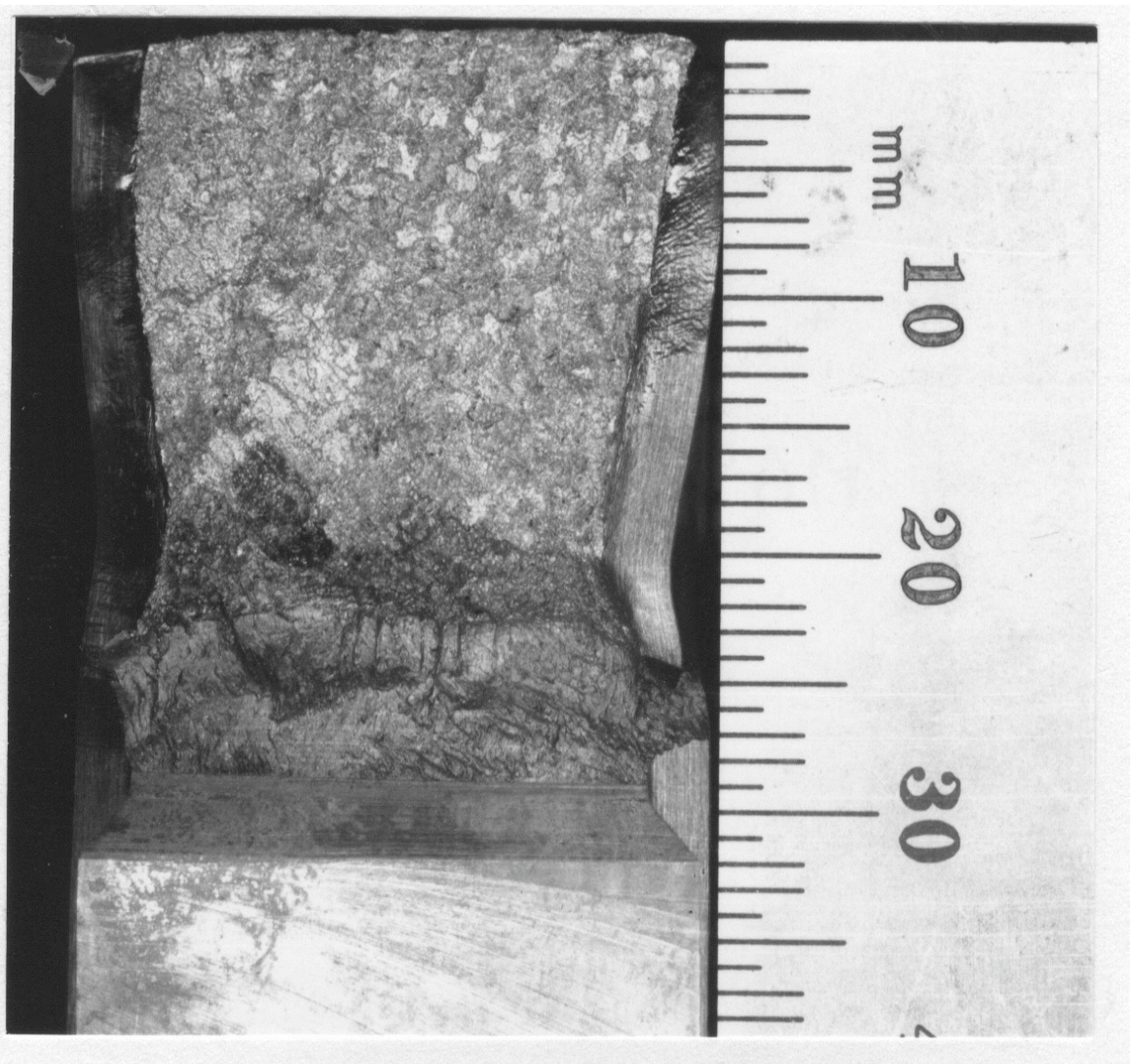

Figure C-20. Fracture surface of essentially unaged material MA9 from the hot-leg main shutoff valve tested at room temperature 


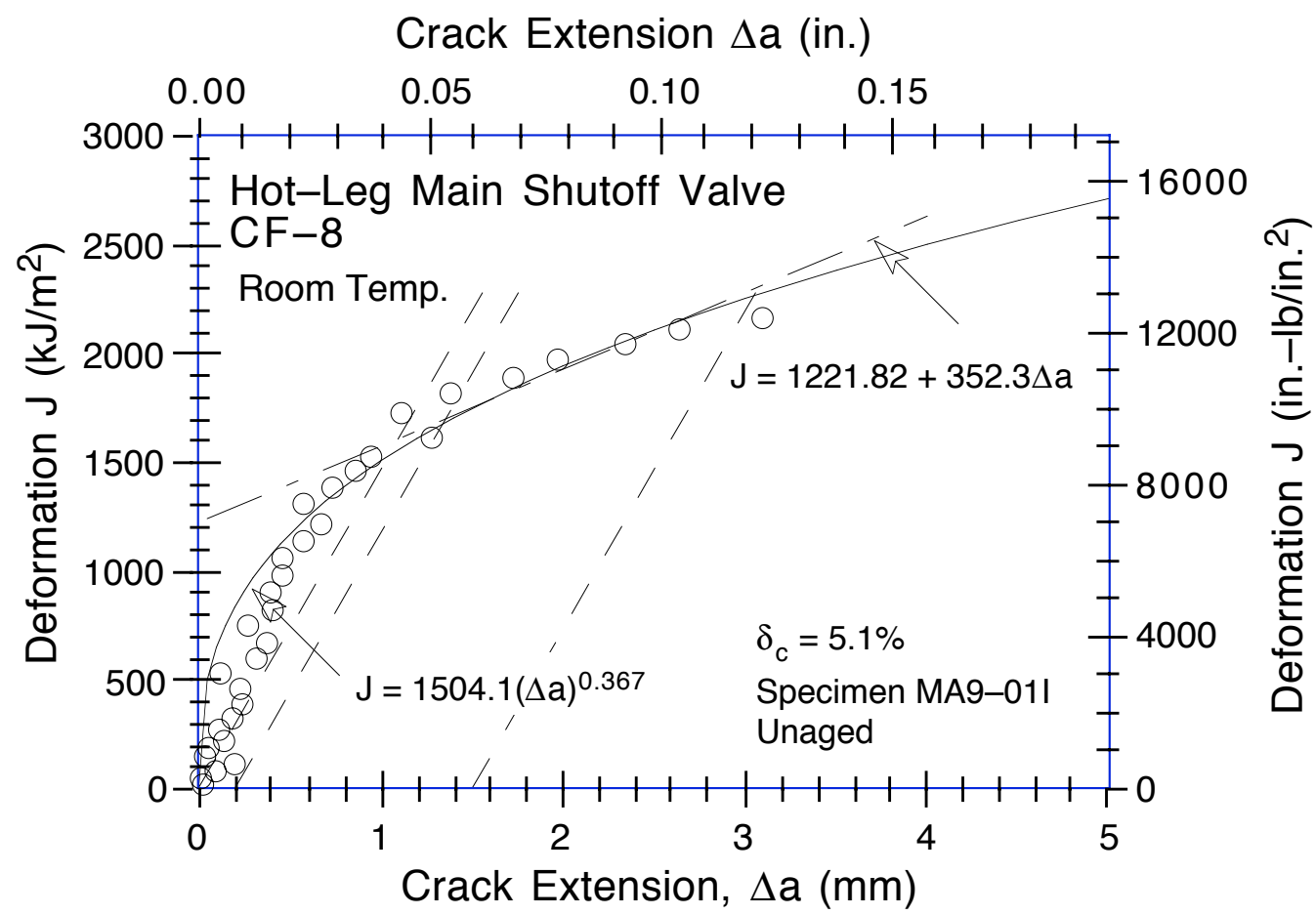

Figure $C-21$. Deformation $J-R$ Curve at room temperature for essentially unaged material MA9 from the hot-leg main shutoff valve

Crack Extension $\Delta$ a (in.)

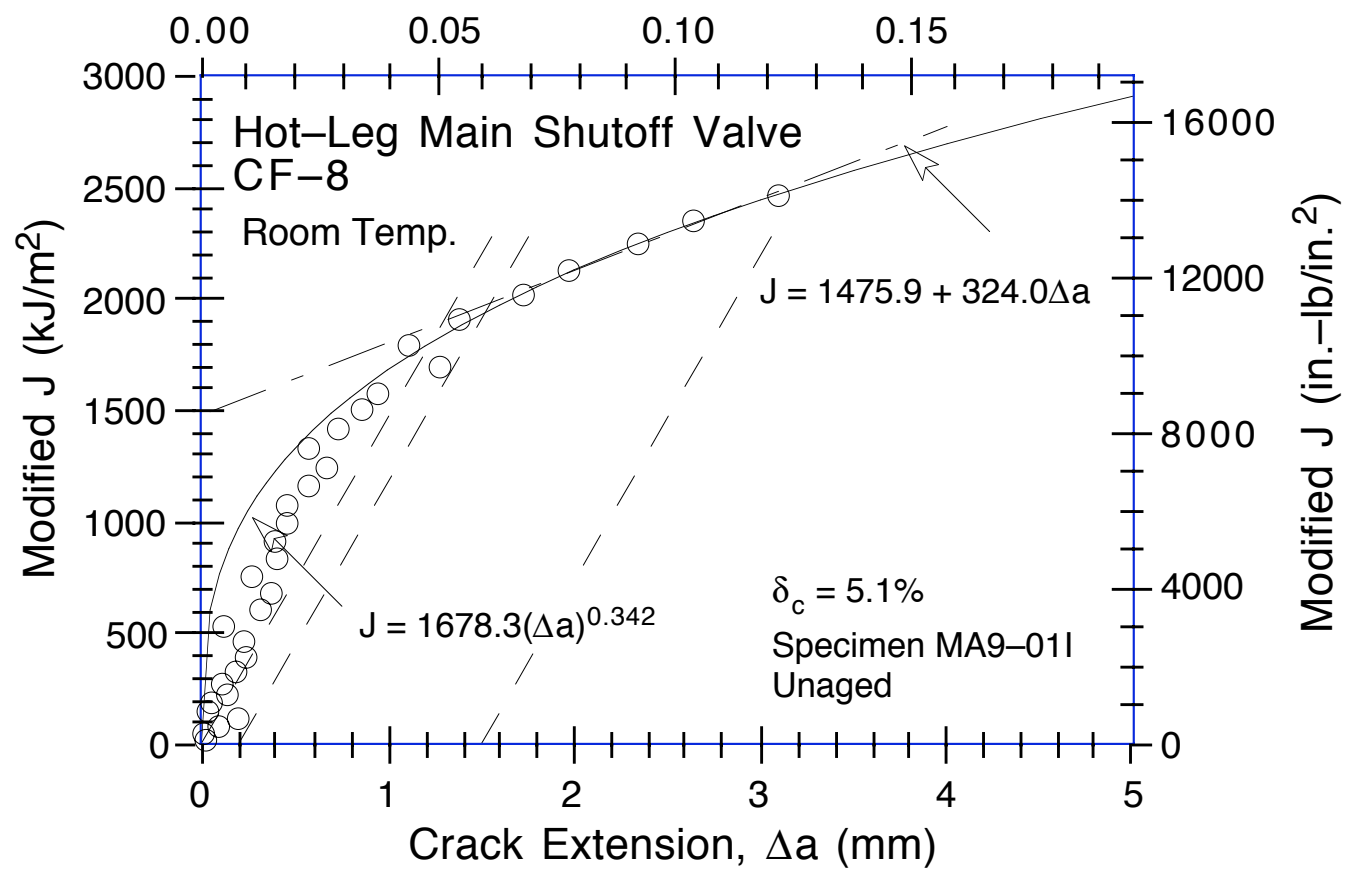

Figure $C$-22. Modified $J-R$ Curve at room temperature for essentially unaged material MA9 from the hot-leg main shutoff valve 
Table C-23. Test data for specimen MA9-020

\begin{tabular}{|c|c|c|c|c|c|}
\hline \multicolumn{2}{|c|}{$\begin{array}{l}\text { Test Number } \\
\text { Material Type } \\
\text { Aging Temp } \\
\text { Spec. Thickness } \\
\text { Spec. Width }\end{array}$} & $\begin{array}{l}0116 \\
: C F-8 \\
: 400{ }^{\circ} \mathrm{C} \\
: 25.37 \mathrm{~mm} \\
50.55 \mathrm{~mm}\end{array}$ & \multicolumn{2}{|c|}{$\begin{array}{l}\text { Test Temp } \\
\text { Heat Number } \\
\text { Aging Time } \\
\text { Net Thickness } \\
\text { Flow Stress }\end{array}$} & $\begin{array}{l}: 25^{\circ} \mathrm{C} \\
: \mathrm{MA} 9 \\
: 10,000 \mathrm{~h} \\
: 20.24 \mathrm{~mm} \\
: 372.20 \mathrm{MPa}\end{array}$ \\
\hline $\begin{array}{c}\text { Unload } \\
\text { Number }\end{array}$ & $\begin{array}{c}J_{d} \\
\left(k J / m^{2}\right)\end{array}$ & $\begin{array}{c}J_{m} \\
\left(k J / m^{2}\right)\end{array}$ & $\begin{array}{c}\Delta \mathrm{a} \\
(\mathrm{m} \mathrm{m})\end{array}$ & $\begin{array}{l}\text { Load } \\
(\mathrm{kN})\end{array}$ & $\begin{array}{c}\text { Deflection } \\
(\mathrm{m} \mathrm{m})\end{array}$ \\
\hline 1 & 13.83 & 13.80 & -0.0745 & 17.787 & 0.255 \\
\hline 2 & 39.18 & 39.29 & 0.0088 & 21.269 & 0.505 \\
\hline 3 & 73.62 & 73.81 & 0.0298 & 23.272 & 0.807 \\
\hline 4 & 110.41 & 111.27 & 0.1450 & 24.780 & 1.107 \\
\hline 5 & 149.59 & 150.41 & 0.1396 & 25.768 & 1.410 \\
\hline 6 & 190.24 & $\begin{array}{l}190.92 \\
\end{array}$ & 0.1266 & 26.590 & 1.708 \\
\hline 7 & 232.68 & 232.80 & 0.0843 & 27.510 & 2.008 \\
\hline 8 & 275.00 & 276.98 & 0.2024 & 28.108 & 2.309 \\
\hline 9 & 319.73 & 320.70 & 0.1477 & 29.001 & 2.610 \\
\hline 10 & 379.67 & 381.60 & 0.1907 & 29.732 & 3.007 \\
\hline 11 & 443.28 & 443.94 & 0.1421 & 30.345 & 3.409 \\
\hline 12 & 505.85 & 508.32 & 0.2028 & 31.312 & 3.808 \\
\hline 13 & 550.62 & 557.78 & 0.3468 & 31.698 & 4.109 \\
\hline 14 & 591.13 & 598.31 & 0.3474 & 32.044 & 4.358 \\
\hline 15 & 631.50 & 640.92 & 0.4071 & 32.440 & 4.609 \\
\hline 16 & 683.02 & 692.50 & 0.4084 & 32.890 & 4.913 \\
\hline 17 & 736.11 & 743.00 & 0.3495 & $\begin{array}{l}33.057 \\
33.05\end{array}$ & 5.207 \\
\hline 18 & 781.88 & 797.52 & 0.5354 & 33.372 & 5.511 \\
\hline 19 & 833.29 & 849.02 & 0.5370 & 33.819 & 5.809 \\
\hline 20 & 882.81 & 903.43 & 0.6285 & 34.209 & 6.110 \\
\hline 21 & 936.42 & 957.81 & 0.6420 & 34.352 & 6.414 \\
\hline 22 & 987.50 & 1012.30 & 0.6988 & 34.354 & 6.710 \\
\hline 23 & 1033.67 & 1067.99 & 0.8490 & 34.790 & 7.010 \\
\hline 24 & 1084.35 & 1123.10 & 0.9154 & 34.969 & 7.311 \\
\hline 25 & 1133.63 & 1180.03 & 1.0247 & 34.952 & 7.614 \\
\hline 26 & 1197.48 & 1254.08 & 1.1614 & 34.913 & 8.007 \\
\hline 27 & 1247.27 & 1321.00 & 1.3803 & 34.590 & 8.359 \\
\hline 28 & 1301.39 & 1386.13 & $\begin{array}{l}1.5143 \\
\end{array}$ & $\begin{array}{l}34.438 \\
34.03\end{array}$ & $\begin{array}{l}0.709 \\
8.709\end{array}$ \\
\hline 29 & 1343.73 & 1453.15 & 1.8017 & 33.969 & 9.059 \\
\hline 30 & 1395.16 & 1517.71 & 1.9480 & 33.420 & 9.412 \\
\hline 31 & 1437.91 & 1591.83 & 2.2820 & 32.406 & 9.807 \\
\hline 32 & 1457.73 & 1665.33 & $\begin{array}{l}2.8338 \\
\end{array}$ & 31.699 & 10.209 \\
\hline 33 & 1507.88 & 1754.23 & $\begin{array}{l}3.2127 \\
\end{array}$ & 30.890 & 10.707 \\
\hline 34 & 1541.95 & 1847.34 & 3.7634 & 29.700 & 11.220 \\
\hline 35 & 1577.40 & 1933.30 & 4.2147 & 28.848 & 11.712 \\
\hline 36 & 1624.78 & 2039.47 & 4.7128 & 27.776 & 12.310 \\
\hline 37 & 1677.20 & 2143.42 & 5.1273 & 27.082 & 12.908 \\
\hline 38 & 1743.35 & 2247.97 & 5.4200 & 26.519 & 13.510 \\
\hline 39 & 1784.66 & 2353.15 & 5.8843 & 25.486 & 14.109 \\
\hline 40 & 1817.31 & 2470.93 & 6.4732 & 24.078 & 14.806 \\
\hline
\end{tabular}


Table C-24. Deformation JIC and J-R curve results for specimen MA9-020

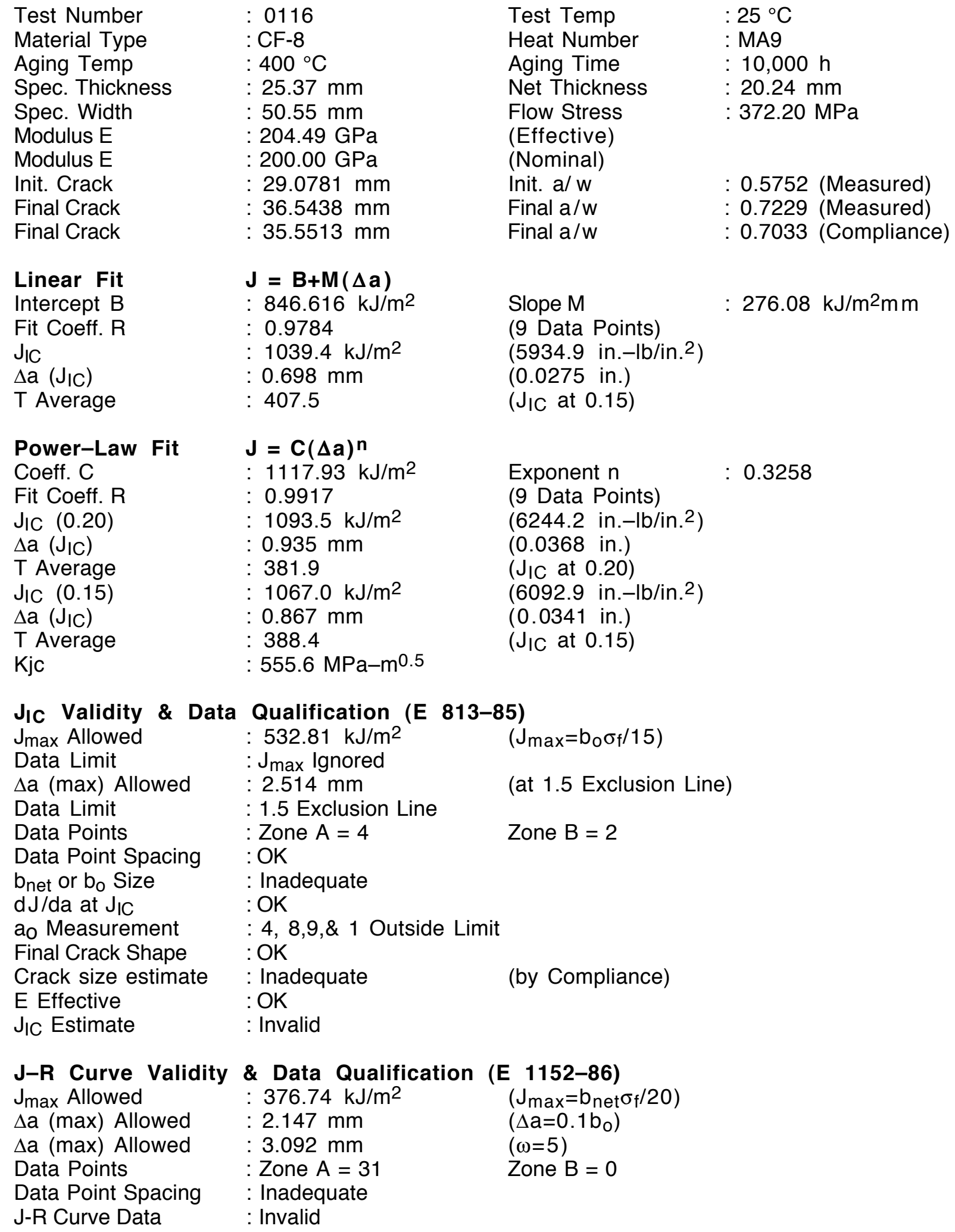


Table C-25. Modified J/C and J-R curve results for specimen MA9-020

\begin{tabular}{|c|c|c|c|}
\hline $\begin{array}{l}\text { Linear Fit } \\
\text { Intercept B } \\
\text { Fit Coeff. R } \\
J_{I C} \\
\Delta \text { a (JIC) } \\
\text { T Average }\end{array}$ & $\begin{array}{l}\mathbf{J}=\mathbf{B}+\mathbf{M}(\Delta \mathbf{a}) \\
: 841.109 \mathrm{~kJ} / \mathrm{m}^{2} \\
: 0.9917 \\
: 1090.7 \mathrm{~kJ} / \mathrm{m}^{2} \\
: 0.733 \mathrm{~mm} \\
: 502.9\end{array}$ & $\begin{array}{l}\text { Slope } M \\
\text { (8 Data Points) } \\
\left(6228.3 \text { in. }-\mathrm{lb} / \mathrm{in}^{2}\right) \\
(0.0288 \text { in. }) \\
\left(\mathrm{J}_{\mathrm{IC}} \text { at } 0.15\right)\end{array}$ & : $340.72 \mathrm{~kJ} / \mathrm{m}^{2} \mathrm{~mm}$ \\
\hline $\begin{array}{l}\text { Power-Law Fit } \\
\text { Coeff. C } \\
\text { Fit Coeff. R } \\
\mathrm{J}_{\mathrm{IC}}(0.20) \\
\Delta \mathrm{a}\left(\mathrm{J}_{\mathrm{IC}}\right) \\
\text { T Average } \\
\mathrm{J}_{\mathrm{IC}}(0.15) \\
\Delta \mathrm{a}\left(\mathrm{J}_{\mathrm{IC}}\right) \\
\text { T Average } \\
\text { Kjc }\end{array}$ & $\begin{array}{l}\mathbf{J}=\mathbf{C}(\Delta \mathbf{a})^{\mathbf{n}} \\
: 1171.72 \mathrm{~kJ} / \mathrm{m}^{2} \\
: 0.9978 \\
: 1163.4 \mathrm{~kJ} / \mathrm{m}^{2} \\
: 0.981 \mathrm{~mm} \\
: 464.2 \\
: 1130.1 \mathrm{~kJ} / \mathrm{m}^{2} \\
: 0.909 \mathrm{~mm} \\
: 471.6 \\
: 588.3 \mathrm{MPa}-\mathrm{m}^{0.5}\end{array}$ & $\begin{array}{l}\text { Exponent } n \\
(8 \text { Data Points) } \\
\left(6643.4 \text { in.-lb/in. }{ }^{2}\right) \\
(0.0386 \text { in. }) \\
\left(J_{I C} \text { at } 0.20\right) \\
\left(6453.2 \text { in. }-\mathrm{lb} / \text { in. }^{2}\right) \\
(0.0358 \text { in. }) \\
\left(J_{I C} \text { at } 0.15\right)\end{array}$ & 0.3792 \\
\hline
\end{tabular}

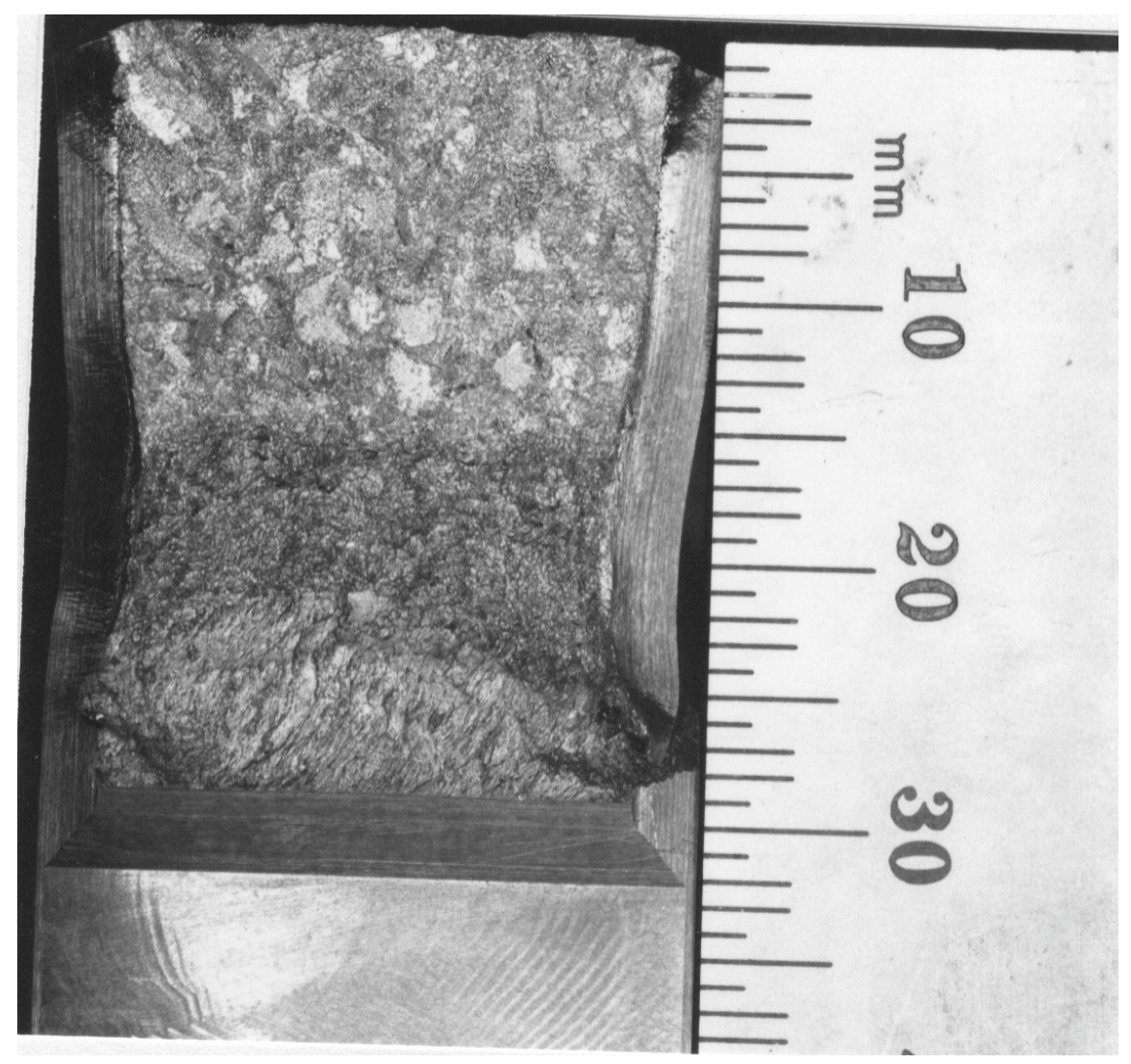

Figure C-23. Fracture surface of MA9 material from cooler region of the hot-leg main shutoff valve aged $10,000 \mathrm{~h}$ at $400^{\circ} \mathrm{C}$ and tested at $25^{\circ} \mathrm{C}$ 


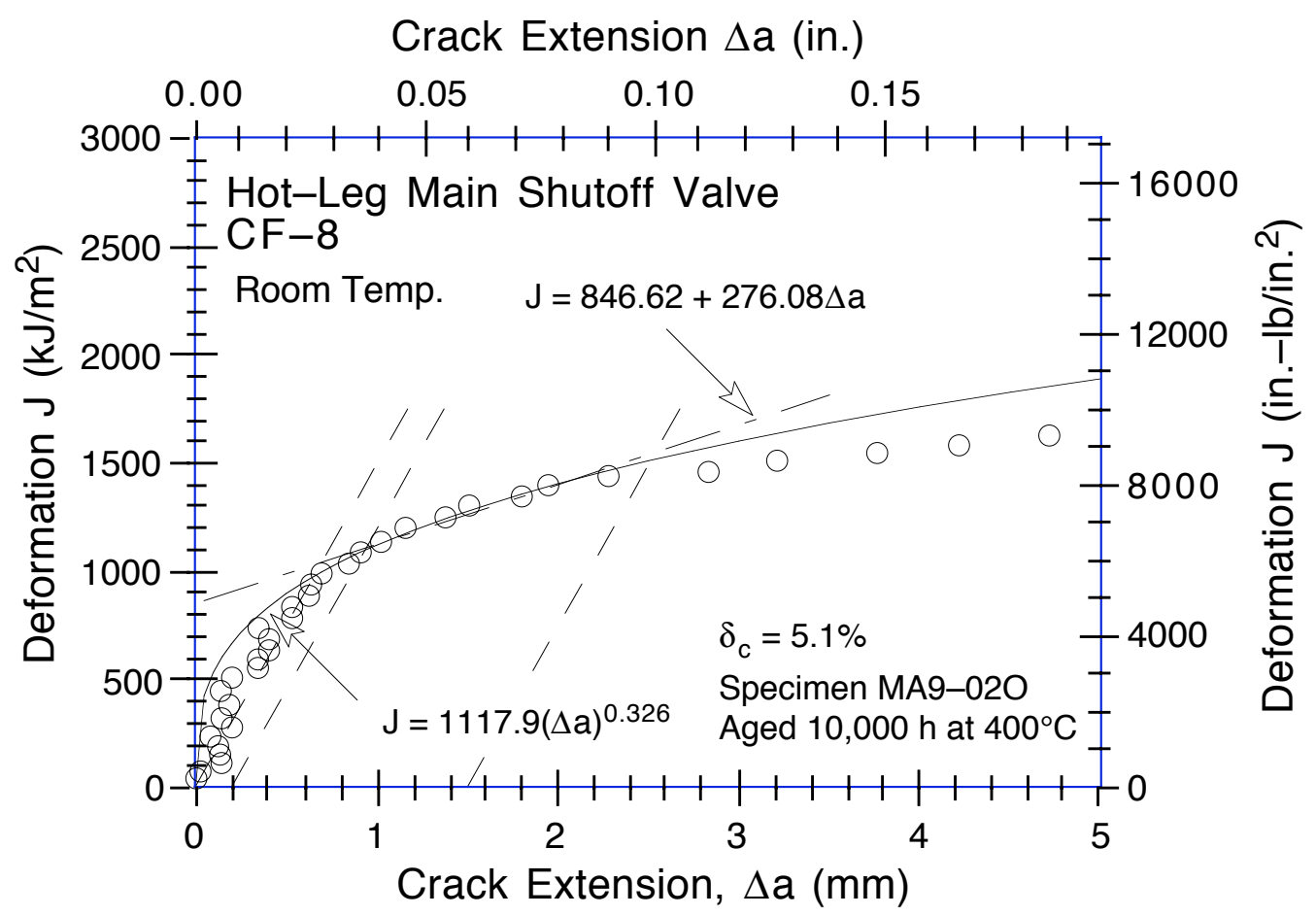

Figure $C-24$. Deformation $J-R$ Curve at room temperature for material from cooler region of the hot-leg main shutoff valve aged $10,000 \mathrm{~h}$ at $400^{\circ} \mathrm{C}$

Crack Extension $\Delta$ a (in.)

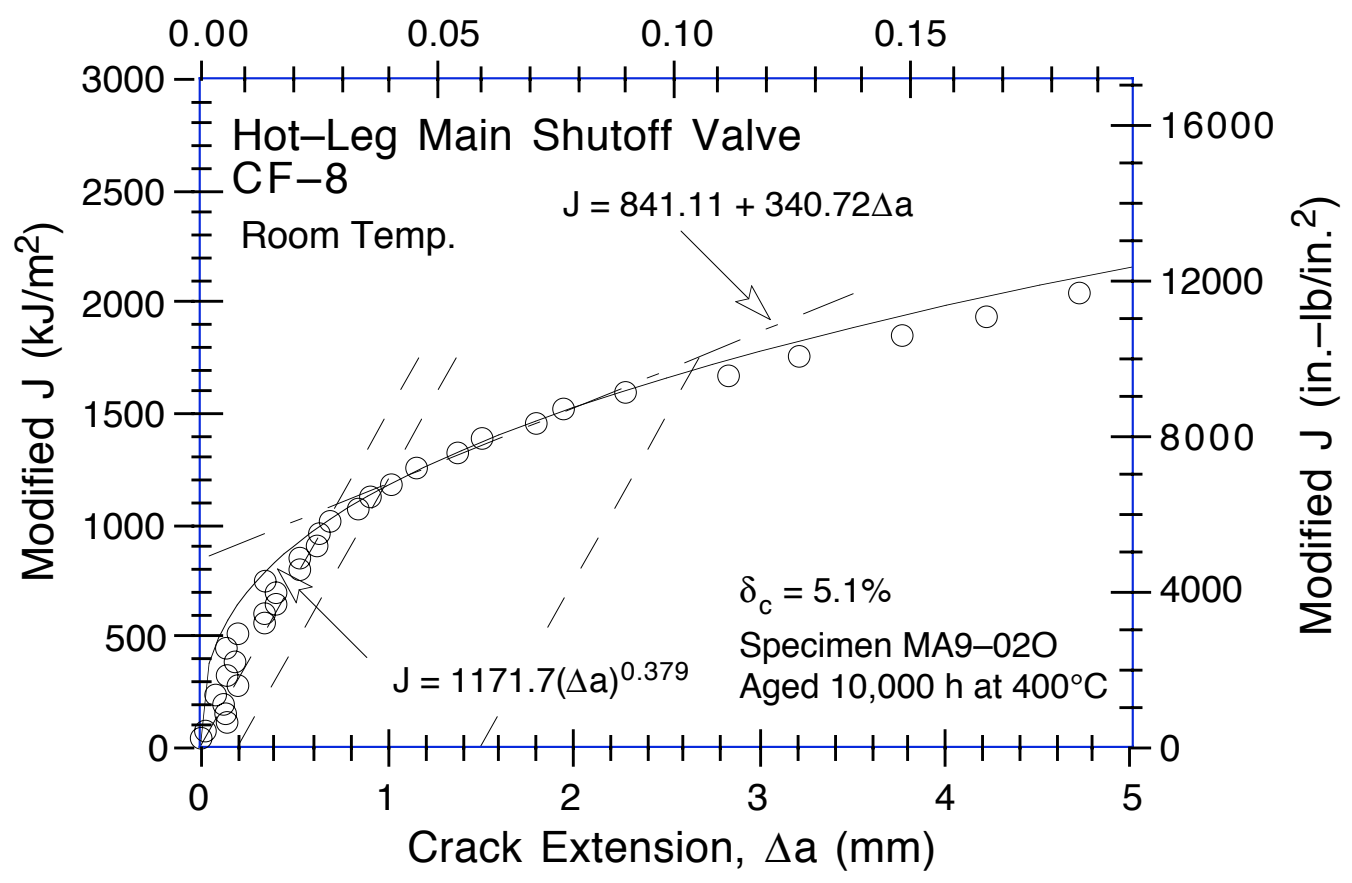

Figure $C-25$. Modified $J-R$ Curve at room temperature for material from cooler region of the hot-leg main shutoff valve aged $10,000 \mathrm{~h}$ at $400^{\circ} \mathrm{C}$ 
Table C-26. Test data for specimen MA9-010

\begin{tabular}{|c|c|c|c|c|c|}
\hline \multicolumn{2}{|c|}{$\begin{array}{l}\text { Test Number } \\
\text { Material Type } \\
\text { Aging Temp. } \\
\text { Spec. Thickness } \\
\text { Spec. Width }\end{array}$} & $\begin{array}{l}: 0097 \\
: C F-8 \\
: 25^{\circ} \mathrm{C} \\
: 25.37 \mathrm{~mm} \\
: 50.78 \mathrm{~mm}\end{array}$ & \multicolumn{2}{|c|}{$\begin{array}{l}\text { Test Temp. } \\
\text { Heat Number } \\
\text { Aging Time } \\
\text { Net Thickness } \\
\text { Flow Stress }\end{array}$} & $\begin{array}{l}: 290^{\circ} \mathrm{C} \\
: \text { MA9 } \\
: 0 \mathrm{~h} \\
: 20.32 \mathrm{~mm} \\
: 259.70 \mathrm{MPa}\end{array}$ \\
\hline $\begin{array}{c}\text { Unload } \\
\text { Number }\end{array}$ & $\begin{array}{c}J_{d} \\
\left(k J / m^{2}\right)\end{array}$ & $\begin{array}{c}J_{m} \\
\left(k J / m^{2}\right)\end{array}$ & $\begin{array}{c}\Delta \mathrm{a} \\
(\mathrm{mm})\end{array}$ & $\begin{array}{l}\text { Load } \\
(\mathrm{kN})\end{array}$ & $\begin{array}{l}\text { Deflection } \\
(\mathrm{m} \mathrm{m})\end{array}$ \\
\hline 1 & 14.34 & 14.39 & 0.0797 & 13.618 & 0.306 \\
\hline 2 & 36.13 & 35.84 & -0.1083 & 15.415 & 0.610 \\
\hline 3 & 59.55 & 60.13 & 0.1718 & 16.498 & 0.910 \\
\hline 4 & 88.64 & 88.56 & 0.0326 & 17.400 & 1.258 \\
\hline 5 & 117.70 & 120.72 & 0.5089 & 18.201 & 1.609 \\
\hline 6 & 151.18 & 150.68 & 0.0908 & 18.899 & 1.955 \\
\hline 7 & 184.01 & 185.95 & 0.3256 & 19.483 & 2.309 \\
\hline 8 & 213.44 & 215.63 & 0.3463 & 20.120 & 2.614 \\
\hline 9 & 246.50 & 244.92 & 0.0763 & 20.559 & 2.911 \\
\hline 10 & 275.82 & 277.06 & 0.2551 & 21.138 & 3.210 \\
\hline 11 & 309.73 & 307.74 & 0.0726 & 21.611 & 3.510 \\
\hline 12 & 338.24 & 341.35 & 0.3343 & 21.986 & 3.809 \\
\hline 13 & 373.67 & 373.27 & 0.1710 & 22.447 & 4.109 \\
\hline 14 & 399.18 & 409.10 & 0.6142 & 23.003 & 4.410 \\
\hline 15 & 440.83 & 441.06 & 0.2341 & 23.332 & 4.711 \\
\hline 16 & 469.52 & 478.37 & 0.5486 & 23.739 & 5.008 \\
\hline 17 & 511.52 & 512.78 & 0.2930 & 24.220 & 5.312 \\
\hline 18 & 545.17 & 550.78 & 0.4299 & 24.574 & 5.612 \\
\hline 19 & 582.42 & 587.26 & 0.4070 & 25.003 & 5.911 \\
\hline 20 & 626.87 & 623.98 & 0.1951 & 25.254 & 6.209 \\
\hline 21 & 659.80 & 663.50 & 0.3657 & 25.569 & 6.510 \\
\hline 22 & 703.80 & 701.05 & 0.2083 & 25.913 & 6.813 \\
\hline 23 & 727.97 & 741.42 & 0.5862 & 26.266 & 7.109 \\
\hline 24 & 770.82 & 780.64 & 0.5060 & 26.537 & 7.420 \\
\hline 25 & 799.04 & 821.18 & 0.7657 & 26.620 & 7.713 \\
\hline 26 & 842.07 & 859.53 & 0.6720 & 26.770 & 8.008 \\
\hline 27 & 872.30 & 902.33 & 0.9133 & 27.041 & 8.311 \\
\hline 28 & 919.19 & 942.32 & 0.7872 & 27.323 & 8.613 \\
\hline 29 & 950.89 & 985.43 & 0.9874 & 27.388 & 8.911 \\
\hline 30 & 998.48 & 1025.99 & 0.8697 & 27.745 & 9.209 \\
\hline 31 & 1040.91 & 1069.79 & 0.8915 & 28.078 & 9.511 \\
\hline 32 & 1061.78 & 1114.35 & 1.2600 & 28.238 & 9.812 \\
\hline 33 & 1116.21 & 1158.71 & 1.1105 & 28.386 & 10.136 \\
\hline 34 & 1145.87 & 1201.40 & 1.2977 & 28.407 & 10.415 \\
\hline 35 & 1193.94 & 1258.49 & 1.4215 & 28.343 & 10.805 \\
\hline 36 & 1241.06 & 1318.76 & 1.5939 & 28.498 & 11.209 \\
\hline 37 & 1295.22 & 1394.46 & 1.8621 & 28.731 & 11.709 \\
\hline 38 & 1369.53 & 1469.59 & 1.8716 & 28.726 & 12.213 \\
\hline 39 & 1419.72 & 1561.74 & 2.3395 & 28.616 & 12.801 \\
\hline 40 & 1482.36 & 1638.97 & 2. 4941 & 28.132 & 13.316 \\
\hline 41 & 1545.77 & 1731.18 & 2.7835 & 27.830 & 13.912 \\
\hline 42 & 1583.78 & 1823.95 & 3.3095 & 27.206 & 14.511 \\
\hline 43 & 1649.60 & 1919.46 & 3.5801 & 26.376 & 15.152 \\
\hline
\end{tabular}


Table C-27. Deformation J/C and J-R curve results for specimen MA9-010

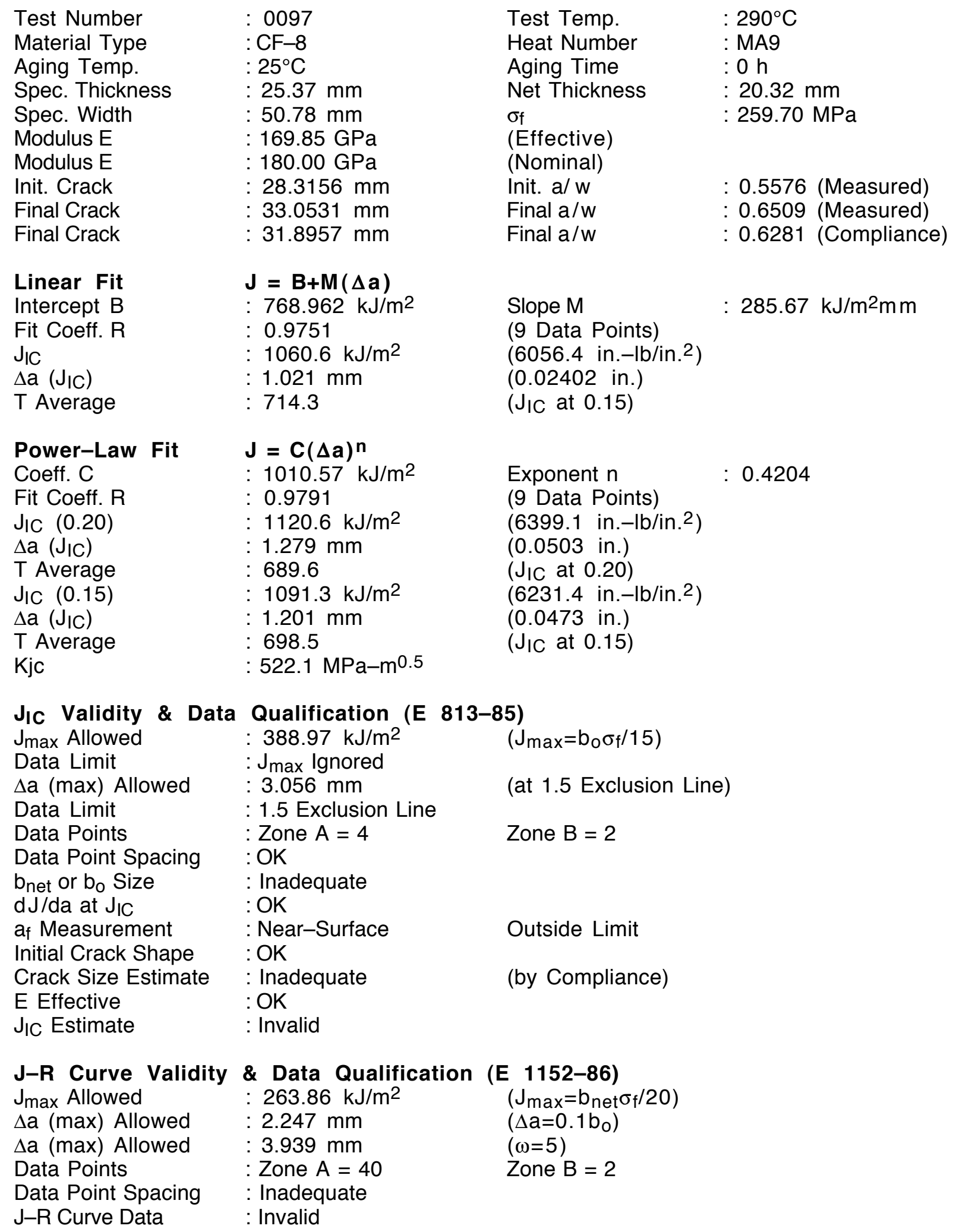


Table C-28. Modified J/C and J-R curve results for specimen MA9-010

\begin{tabular}{|c|c|c|c|}
\hline $\begin{array}{l}\text { Linear Fit } \\
\text { Intercept B } \\
\text { Fit Coeff. R } \\
\mathrm{J}_{\mathrm{IC}} \\
\Delta \mathrm{a}\left(\mathrm{J}_{\mathrm{IC}}\right) \\
\mathrm{T} \text { Average }\end{array}$ & $\begin{array}{l}\mathbf{J}=\mathbf{B}+\mathbf{M}(\Delta \mathbf{a}) \\
: 780.191 \mathrm{~kJ} / \mathrm{m}^{2} \\
: 0.9903 \\
: 1163.0 \mathrm{~kJ} / \mathrm{m}^{2} \\
: 1.120 \mathrm{~mm} \\
: 854.9\end{array}$ & $\begin{array}{l}\text { Slope } M \\
(11 \text { Data Points) } \\
\left(6640.7 \text { in.-lb/in. }{ }^{2}\right) \\
(0.0441 \text { in. }) \\
\left(J_{I C} \text { at } 0.15\right)\end{array}$ & 341.90 \\
\hline $\begin{array}{l}\text { Power-Law Fit } \\
\text { Coeff. C } \\
\text { Fit Coeff. R } \\
\mathrm{J}_{\mathrm{IC}}(0.20) \\
\Delta \mathrm{a}(\mathrm{J} \mathrm{IC}) \\
\text { T Average } \\
\mathrm{J}_{\mathrm{IC}}(0.15) \\
\Delta \mathrm{a}(\mathrm{J} \mathrm{IC}) \\
\text { T Average } \\
\text { KjC }\end{array}$ & $\begin{array}{l}\mathbf{J}=\mathbf{C}(\Delta \mathbf{a})^{\mathbf{n}} \\
: 10.64 .09 \mathrm{~kJ} / \mathrm{m}^{2} \\
: 0.9902 \\
: 1245.8 \mathrm{~kJ} / \mathrm{m}^{2} \\
: 1.399 \mathrm{~mm} \\
: 805.3 \\
: 1209.9 \mathrm{~kJ} / \mathrm{m}^{2} \\
: 1.315 \mathrm{~mm} \\
: 814.7 \\
: 560.2 \mathrm{MPa}-\mathrm{m}^{0.5}\end{array}$ & $\begin{array}{l}\text { Exponent } n \\
\text { ( } 7 \text { Data Points) } \\
\left(7113.8 \text { in.-lb/in. }{ }^{2}\right) \\
(0.0551 \text { in.) } \\
\left(J_{I C} \text { at } 0.20\right) \\
\left(6908.6 \text { in. }-\mathrm{lb} / \text { in. }^{2}\right) \\
(0.0518 \text { in.) } \\
\left(J_{I C} \text { at } 0.15\right)\end{array}$ & 0.4693 \\
\hline
\end{tabular}

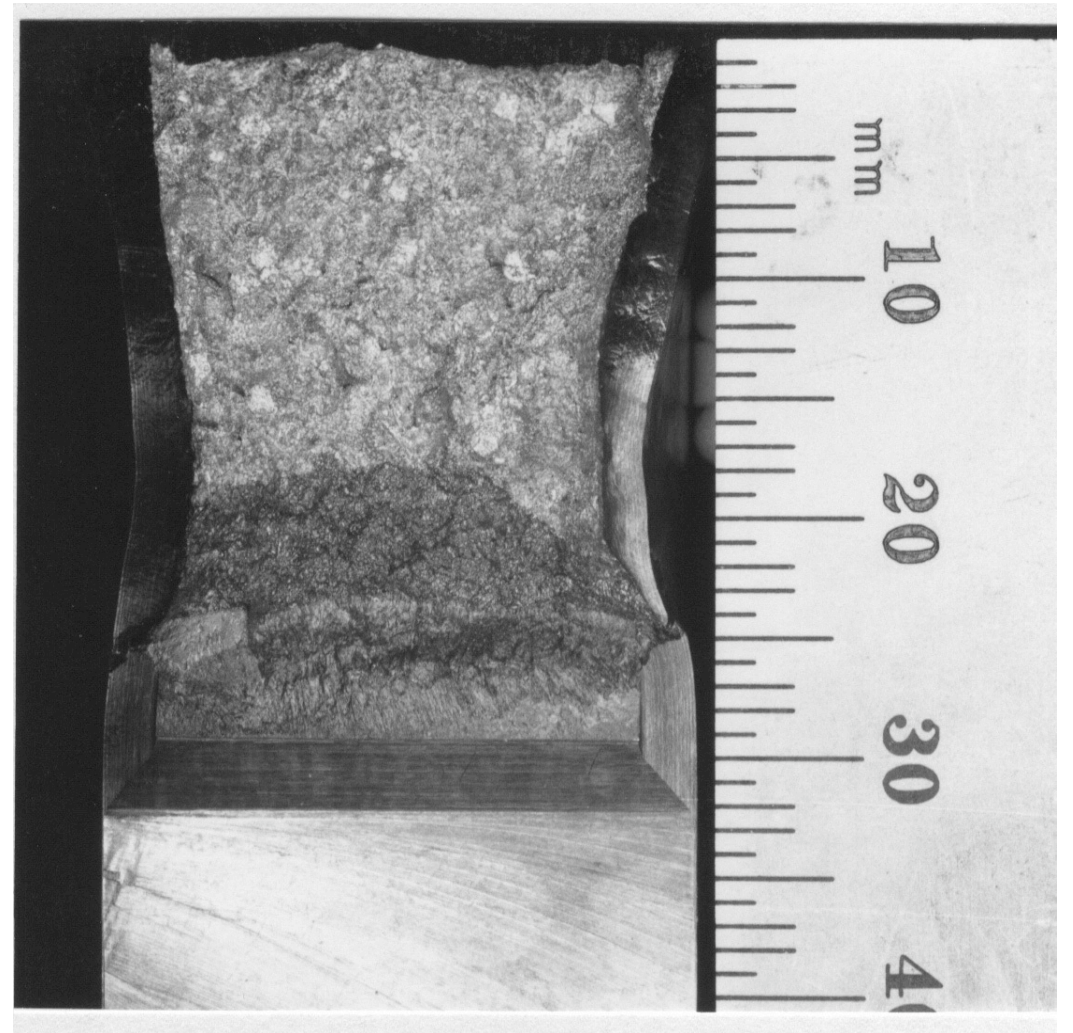

Figure C-26. Fracture surface of essentially unaged material MA9 from the hot-leg main shutoff valve tested at $290^{\circ} \mathrm{C}$ 


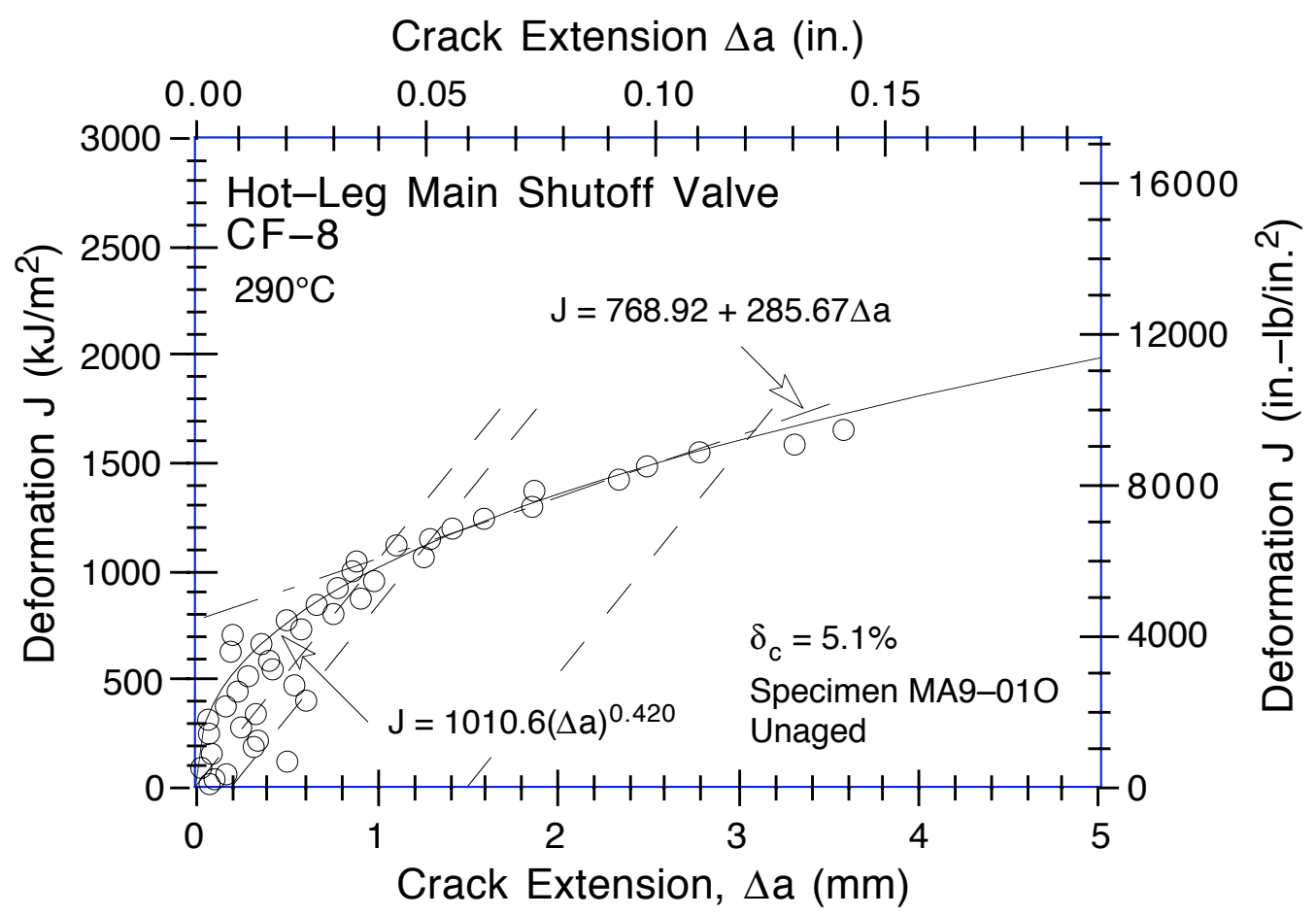

Figure C-27. Deformation $J-R$ Curve at $290^{\circ} \mathrm{C}$ for essentially unaged material MA9 from the hot-leg main shutoff valve

Crack Extension $\Delta$ a (in.)

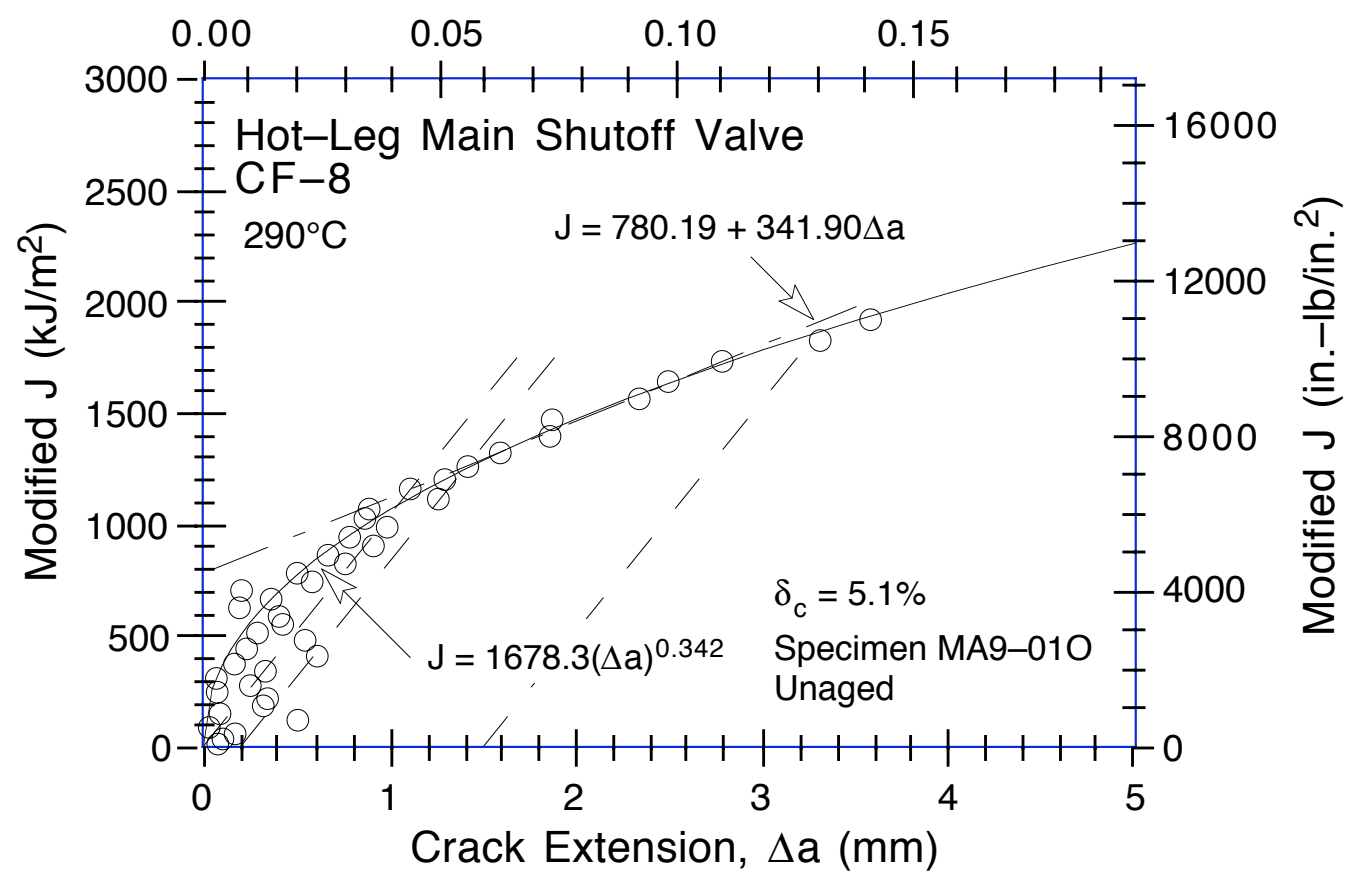

Figure C-28. Modified $J-R$ Curve at $290^{\circ} \mathrm{C}$ for essentially unaged material MA9 from the hot-leg main shutoff valve 
Table C-29. Test data for specimen MA9-02I

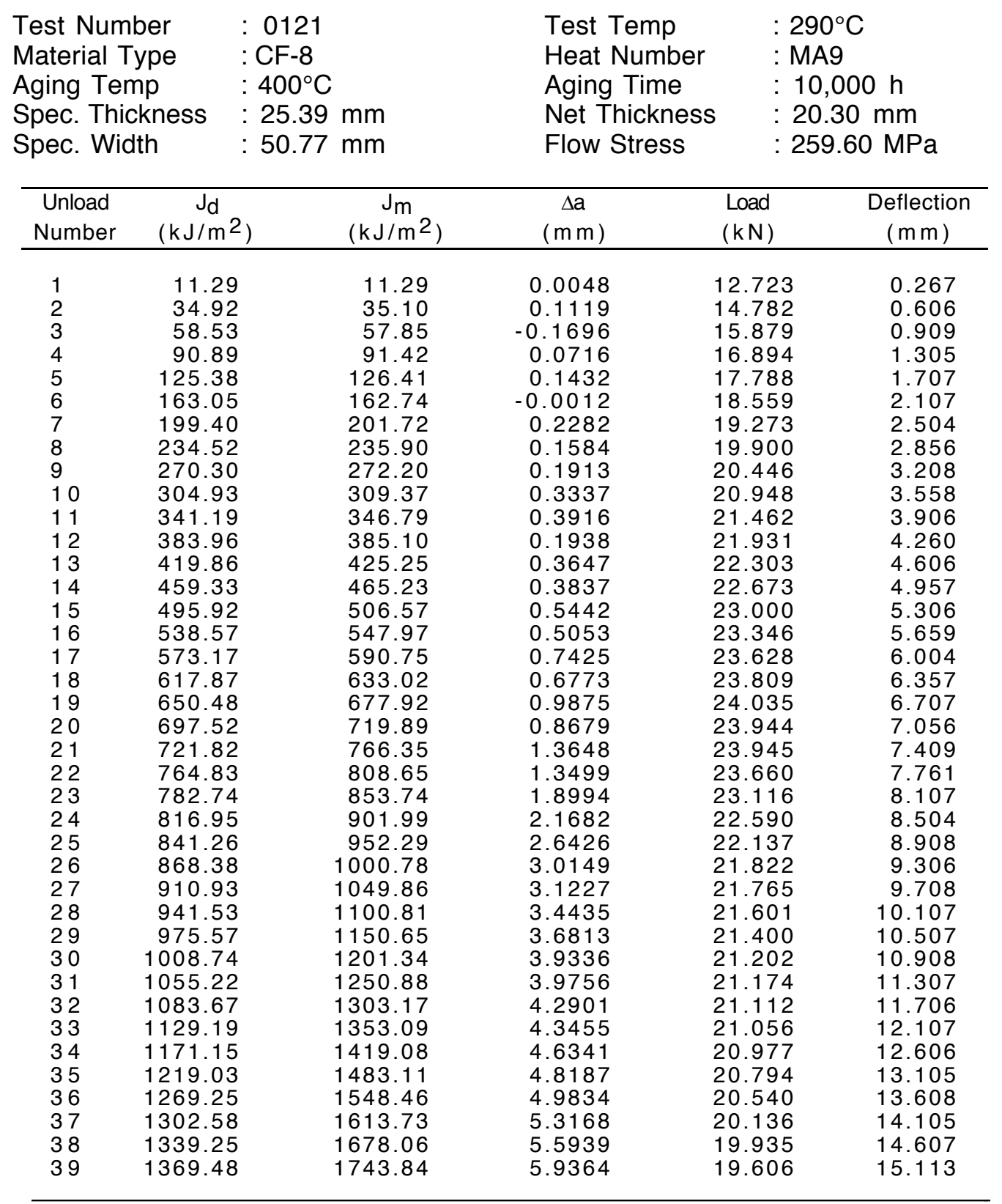


Table C-30. Deformation J/C and J-R curve results for specimen MA9-02I

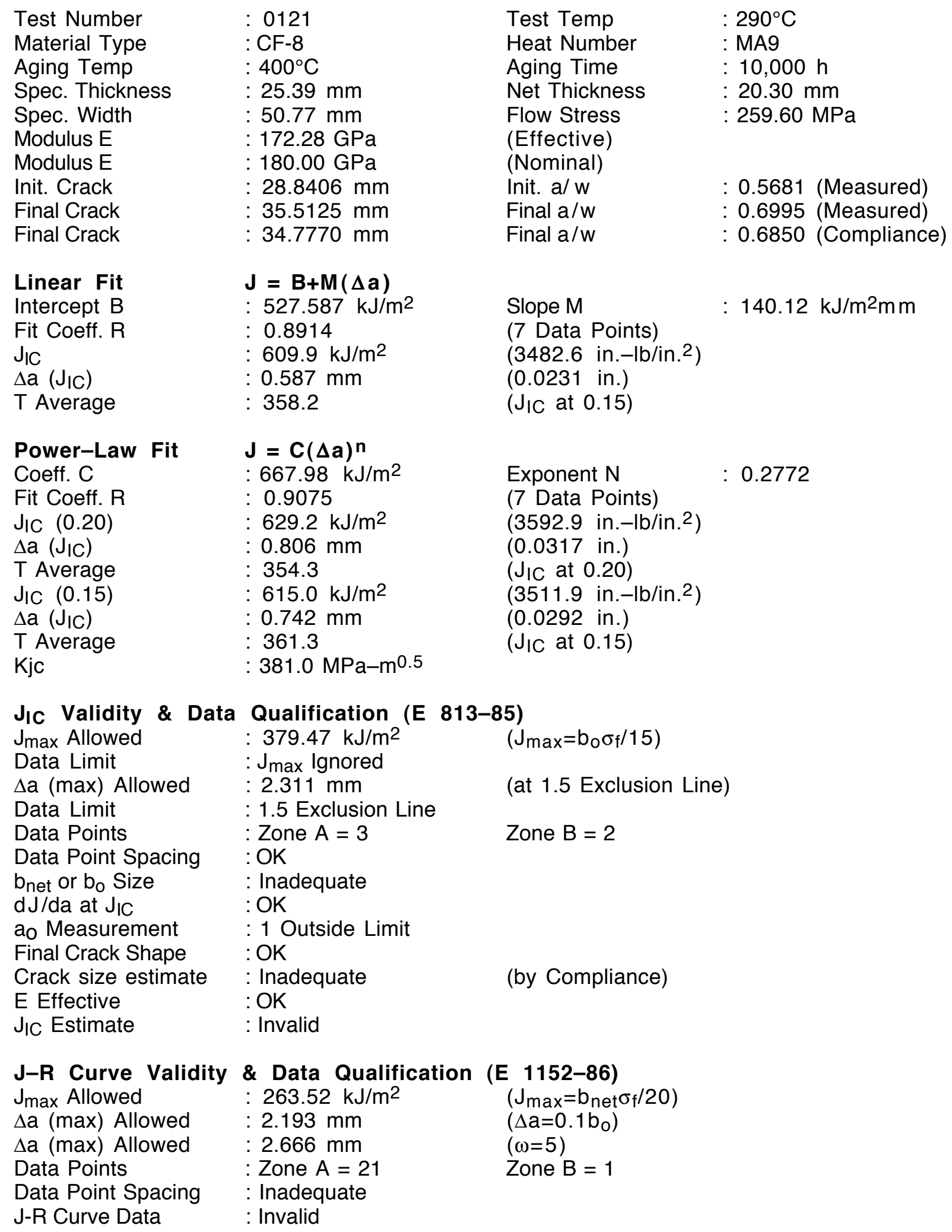


Table C-31. Modified J/C and J-R curve results for specimen MA9-02I

\begin{tabular}{|c|c|c|c|}
\hline $\begin{array}{l}\text { Linear Fit } \\
\text { Intercept B } \\
\text { Fit Coeff. R } \\
\mathrm{J}_{\mathrm{IC}} \\
\Delta \mathrm{a}\left(\mathrm{J}_{\mathrm{IC}}\right) \\
\mathrm{T} \text { Average }\end{array}$ & $\begin{array}{l}\mathbf{J}=\mathbf{B}+\mathbf{M}(\Delta \mathbf{a}) \\
: 562.439 \mathrm{~kJ} / \mathrm{m}^{2} \\
: 0.9510 \\
: 662.4 \mathrm{~kJ} / \mathrm{m}^{2} \\
: 0.638 \mathrm{~mm} \\
: 400.7\end{array}$ & $\begin{array}{l}\text { Slope M } \\
\text { (6 Data Points) } \\
\left(3782.6 \text { in. }-\mathrm{lb} / \text { in }^{2}\right) \\
(0.0251 \text { in.) } \\
\left(J_{I C} \text { at } 0.15\right)\end{array}$ & 156.74 \\
\hline $\begin{array}{l}\text { Power-Law Fit } \\
\text { Coeff. C } \\
\text { Fit Coeff. R } \\
\mathrm{J}_{\mathrm{IC}}(0.20) \\
\Delta \mathrm{a}(\mathrm{J} \mathrm{IC}) \\
\text { T Average } \\
\mathrm{J}_{\mathrm{IC}}(0.15) \\
\Delta \mathrm{a}(\mathrm{J} \mathrm{IC}) \\
\text { T Average } \\
\text { KjC }\end{array}$ & $\begin{array}{l}\mathbf{J}=\mathbf{C}(\Delta \mathbf{a})^{\mathbf{n}} \\
: 718.38 \mathrm{~kJ} / \mathrm{m}^{2} \\
: 0.9405 \\
: 689.4 \mathrm{~kJ} / \mathrm{m}^{2} \\
: 0.864 \mathrm{~mm} \\
: 375.9 \\
: 674.5 \mathrm{~kJ} / \mathrm{m}^{2} \\
: 0.800 \mathrm{~mm} \\
: 383.0 \\
: 397.6 \mathrm{MPa}-\mathrm{m}^{0.5}\end{array}$ & $\begin{array}{l}\text { Exponent } \mathrm{N} \\
(6 \mathrm{Data} \text { Points) } \\
\left(3936.4 \text { in.-lb/in. }{ }^{2}\right) \\
(0.0340 \text { in.) } \\
\left(\mathrm{J}_{\mathrm{IC}} \text { at } 0.20\right) \\
\left(3851.6 \text { in. }-\mathrm{lb} / \mathrm{in}^{2}{ }^{2}\right) \\
(0.0315 \text { in.) } \\
\left(\mathrm{J}_{\mathrm{IC}} \text { at } 0.15\right)\end{array}$ & 0.2817 \\
\hline
\end{tabular}

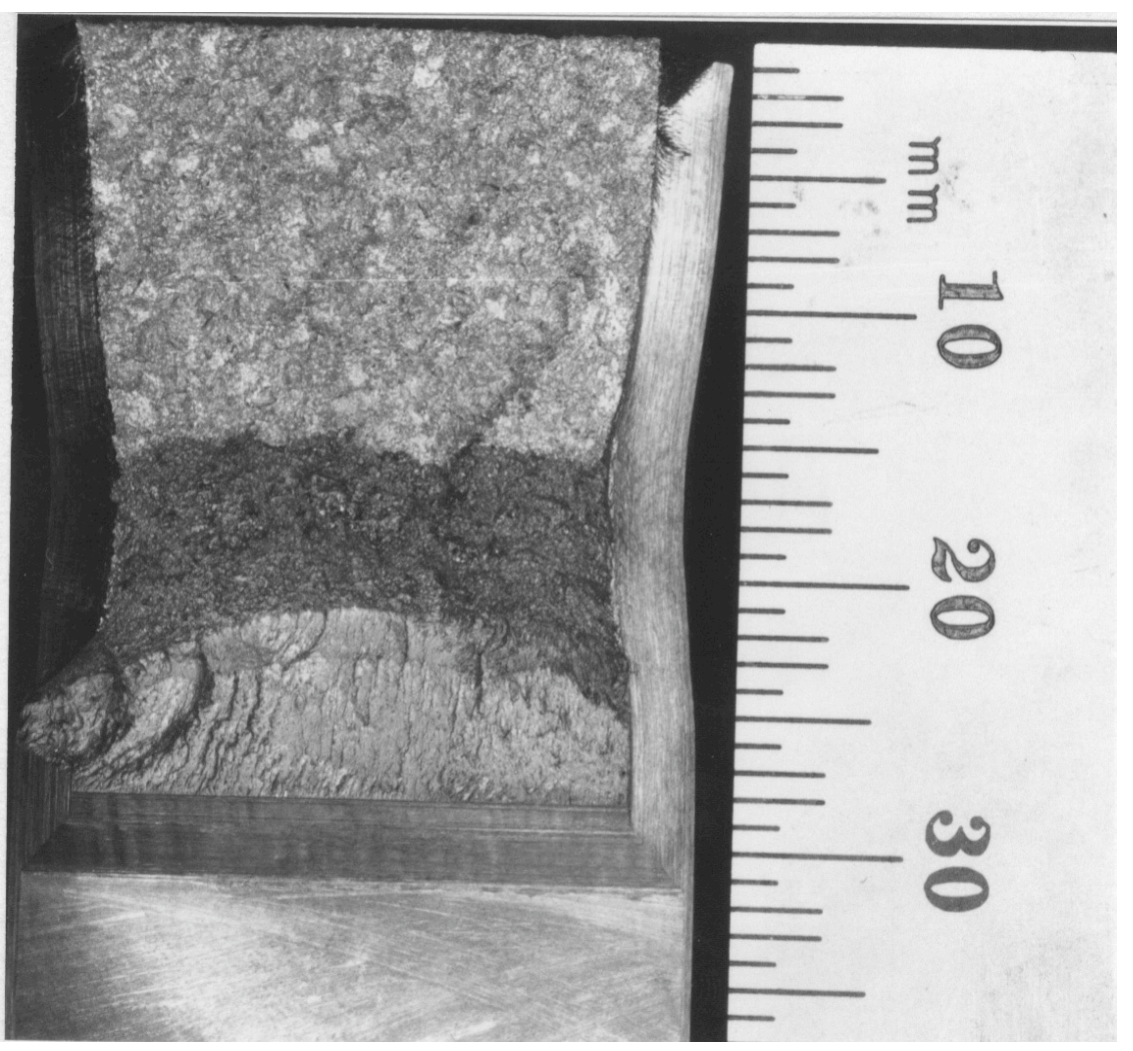

Figure C-29. Fracture surface of MA9 material from cooler region of the hot-leg main shutoff valve aged $10,000 \mathrm{~h}$ at $400^{\circ} \mathrm{C}$ and tested at $290^{\circ} \mathrm{C}$ 


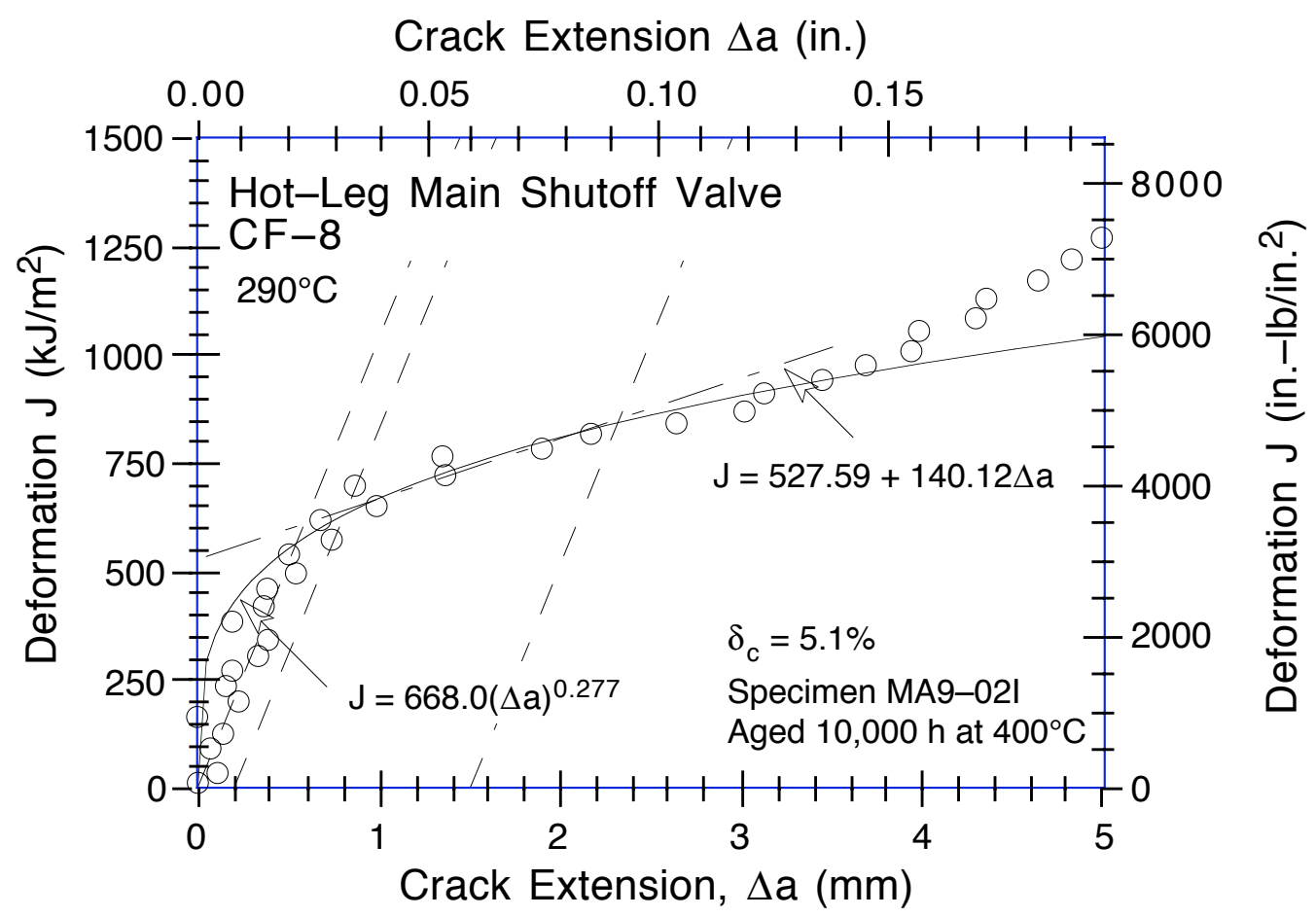

Figure C-30. Deformation $J-R$ Curve at $290^{\circ} \mathrm{C}$ for material from cooler region of the hot-leg main shutoff valve aged $10,000 \mathrm{~h}$ at $400^{\circ} \mathrm{C}$

Crack Extension $\Delta$ a (in.)

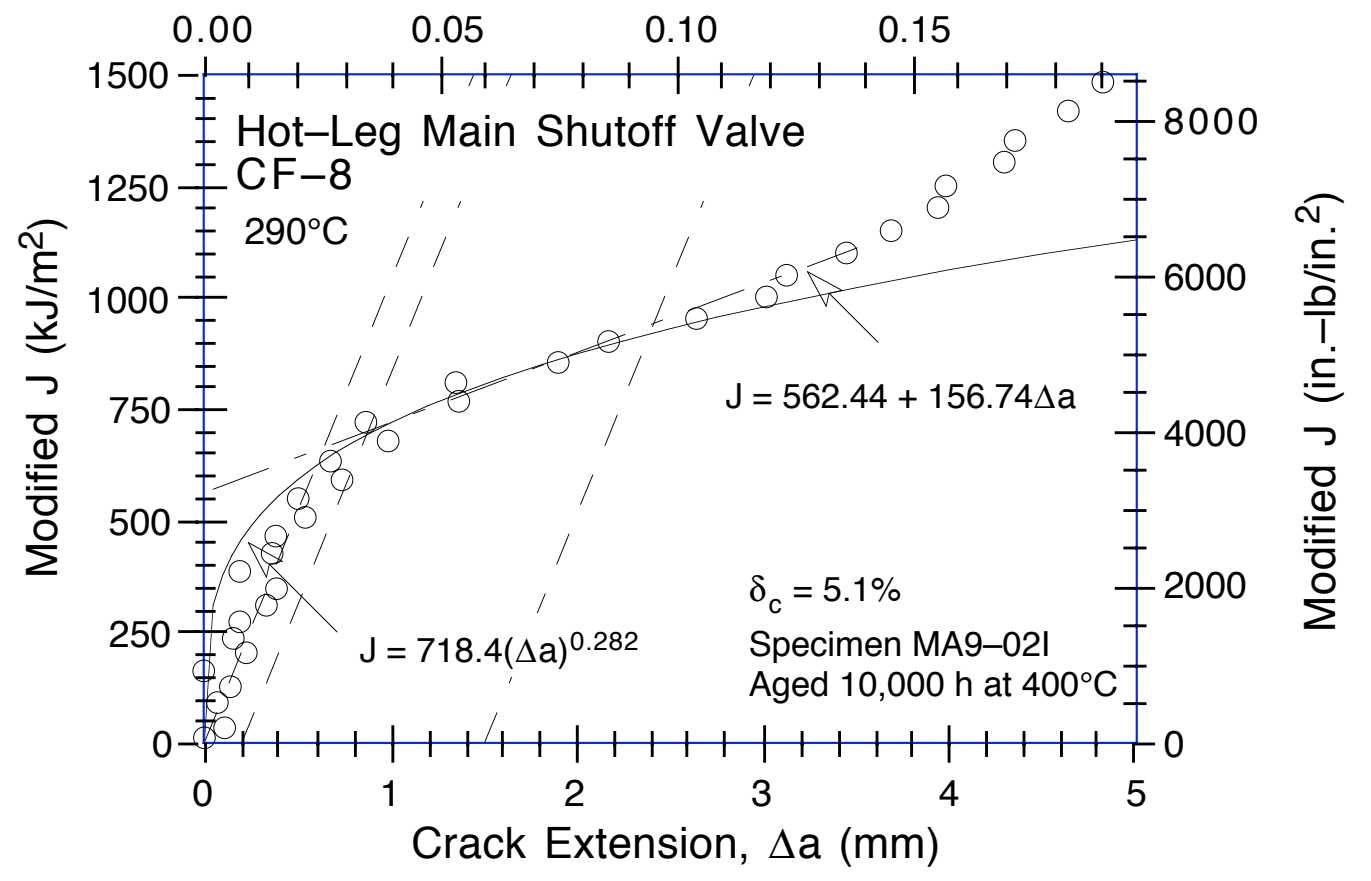

Figure C-31. Modified $J-R$ Curve at $290^{\circ} \mathrm{C}$ for material from cooler region of the hot-leg main shutoff valve aged $10,000 \mathrm{~h}$ at $400^{\circ} \mathrm{C}$ 
Table C-32. Test data for specimen PVC-01

\begin{tabular}{|c|c|c|c|c|c|}
\hline \multicolumn{2}{|c|}{$\begin{array}{l}\text { Test Number } \\
\text { Material Type } \\
\text { Aging Temp. } \\
\text { Spec. Thickness } \\
\text { Spec. Width }\end{array}$} & $\begin{array}{l}: 0078 \\
: C F-8 \\
: 550^{\circ} \mathrm{C} \\
: 25.39 \mathrm{~mm} \\
: 50.81 \mathrm{~mm}\end{array}$ & \multicolumn{2}{|c|}{$\begin{array}{l}\text { Test Temp. } \\
\text { Heat Number } \\
\text { Aging Time } \\
\text { Net Thickness } \\
\text { Flow Stress }\end{array}$} & $\begin{array}{l}: 25^{\circ} \mathrm{C} \\
: \mathrm{PV} \\
: 1 \mathrm{~h} \\
: 20.33 \mathrm{~mm} \\
: 362.04 \mathrm{MPa}\end{array}$ \\
\hline $\begin{array}{l}\text { Unload } \\
\text { Number }\end{array}$ & $\begin{array}{c}J_{d} \\
\left(k J / m^{2}\right)\end{array}$ & $\begin{array}{c}J_{m} \\
\left(k J / m^{2}\right)\end{array}$ & $\begin{array}{c}\Delta \mathrm{a} \\
(\mathrm{m} \mathrm{m})\end{array}$ & $\begin{array}{l}\text { Load } \\
(\mathrm{kN})\end{array}$ & $\begin{array}{c}\text { Deflection } \\
(\mathrm{m} \mathrm{m})\end{array}$ \\
\hline 1 & 9.28 & 9.27 & -0.0854 & 18.185 & 0.202 \\
\hline 2 & 24.89 & 24.94 & -0.0138 & 21.480 & 0.356 \\
\hline 3 & 47.63 & 47.80 & 0.0450 & 23.169 & 0.560 \\
\hline 4 & 77.34 & 77.54 & 0.0552 & 24.533 & 0.808 \\
\hline 5 & 109.64 & 109.41 & -0.0229 & 25.452 & 1.062 \\
\hline 6 & 144.04 & 144.04 & 0.0082 & 26.186 & 1.324 \\
\hline 7 & 175.27 & 175.80 & 0.0630 & 26.771 & 1.560 \\
\hline 8 & 210.19 & 209.31 & -0.0596 & 27.477 & 1.809 \\
\hline 9 & 244.72 & 245.95 & 0.0958 & 28.039 & 2.062 \\
\hline 10 & 279.75 & 280.67 & 0.0757 & 28.443 & 2.310 \\
\hline 11 & 316.30 & 317.49 & 0.0910 & 29.015 & 2.561 \\
\hline 12 & 353.59 & 354.20 & 0.0618 & 29.373 & 2.810 \\
\hline 13 & 398.57 & 400.96 & 0.1399 & 29.795 & 3.116 \\
\hline 14 & 443.95 & 446.34 & 0.1400 & 30.445 & 3.414 \\
\hline 15 & 494.98 & 498.00 & 0.1620 & 30.980 & 3.743 \\
\hline 16 & 536.35 & 540.62 & 0.2020 & 31.261 & 4.011 \\
\hline 17 & 582.66 & 589.33 & 0.2725 & 31.857 & 4.311 \\
\hline 18 & 631.89 & 638.07 & 0.2594 & 32.119 & 4.612 \\
\hline 19 & 679.11 & 688.60 & 0.3423 & 32.506 & 4.913 \\
\hline 20 & 730.57 & 738.16 & 0.2979 & 32.856 & 5.212 \\
\hline 21 & 777.56 & 789.11 & 0.3839 & 33.246 & 5.507 \\
\hline 22 & 840.67 & 856.98 & 0.4793 & 33.677 & 5.900 \\
\hline 23 & 894.93 & 910.87 & 0.4725 & 34.245 & 6.212 \\
\hline 24 & 959.64 & 972.74 & 0.4226 & 34.482 & 6.563 \\
\hline 25 & 1020.71 & 1036.20 & 0.4620 & 35.002 & 6.914 \\
\hline 26 & 1080.32 & 1099.92 & 0.5256 & 35.231 & 7.266 \\
\hline 27 & 1135.99 & 1163.66 & 0.6435 & 35.391 & 7.612 \\
\hline 28 & 1201.69 & 1227.79 & 0.6219 & 35.663 & 7.965 \\
\hline 29 & 1244.56 & 1295.83 & 0.9541 & 35.957 & 8.318 \\
\hline 30 & 1308.68 & 1358.72 & 0.9388 & 36.011 & 8.666 \\
\hline 31 & 1369.48 & 1425.85 & 1.0143 & 36.093 & 9.014 \\
\hline 32 & 1426.25 & 1494.19 & 1.1463 & 36.546 & 9.369 \\
\hline 33 & 1498.09 & 1559.43 & 1.0746 & 36.678 & 9.716 \\
\hline 34 & 1561.29 & 1628.31 & 1.1336 & 36.620 & 10.065 \\
\hline 35 & 1595.84 & 1698.70 & 1.4938 & 36.583 & 10.418 \\
\hline 36 & 1663.56 & 1767.02 & 1.4996 & 36.327 & 10.784 \\
\hline 37 & 1714.56 & 1833.57 & 1.6440 & 36.272 & 11.117 \\
\hline 38 & 1761.24 & 1903.25 & 1.8501 & 35.884 & 11.470 \\
\hline 39 & 1814.33 & 1969.51 & 1.9641 & 35.715 & 11.813 \\
\hline 40 & 1867.58 & 2049.72 & 2.1889 & 35.750 & 12.217 \\
\hline 41 & 1921.93 & 2128.47 & 2.3851 & 35.493 & 12.618 \\
\hline 42 & 1969.85 & 2207.06 & 2.6234 & 35.527 & 13.014 \\
\hline 43 & 2050.46 & 2306.55 & 2.7635 & 35.392 & 13.515 \\
\hline 44 & 2120.58 & 2407.98 & 2.9860 & 35.065 & 14.015 \\
\hline 45 & 2192.55 & 2528.27 & 3.3132 & 33.902 & 14.616 \\
\hline 46 & 2243.34 & 2645.66 & 3.7457 & 32.919 & 15.215 \\
\hline 47 & 2329.05 & 2759.57 & 3.9208 & 32.872 & 15.812 \\
\hline
\end{tabular}


Table C-33. Deformation JIC and J-R curve results for specimen PVC-01

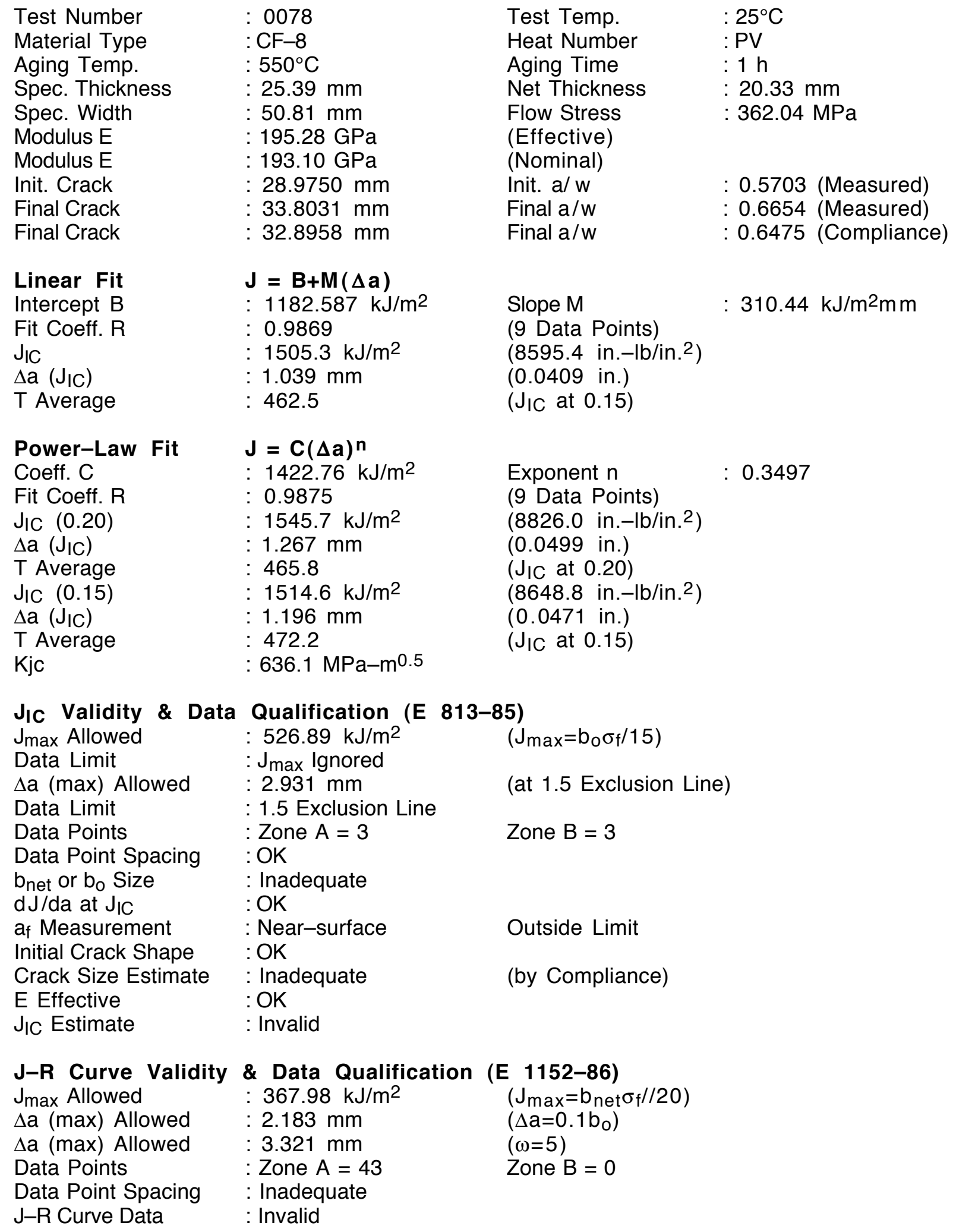


Table C-34. Modified JIC and J-R curve results for specimen PVC-01

\begin{tabular}{|c|c|c|c|}
\hline $\begin{array}{l}\text { Linear Fit } \\
\text { Intercept B } \\
\text { Fit Coeff. R } \\
\mathrm{J}_{\mathrm{IC}} \\
\Delta \mathrm{a}\left(\mathrm{J}_{\mathrm{IC}}\right) \\
\mathrm{T} \text { Average }\end{array}$ & $\begin{array}{l}\mathbf{J}=\mathbf{B}+\mathbf{M}(\Delta \mathbf{a}) \\
: 1093.141 \mathrm{~kJ} / \mathrm{m}^{2} \\
: 0.9954 \\
: 1564.8 \mathrm{~kJ} / \mathrm{m}^{2} \\
: 1.081 \mathrm{~mm} \\
: 650.3\end{array}$ & $\begin{array}{l}\text { Slope M } \\
\text { (10 Data Points) } \\
\left(8935.3 \text { in.-lb/in. }{ }^{2}\right) \\
(0.0425 \text { in.) } \\
\left(J_{I C} \text { at } 0.15\right)\end{array}$ & 436.50 \\
\hline $\begin{array}{l}\text { Power-Law Fit } \\
\text { Coeff. C } \\
\text { Fit Coeff. R } \\
\mathrm{J}_{\mathrm{IC}}(0.20) \\
\Delta \mathrm{a}(\mathrm{J} \mathrm{IC}) \\
\text { T Average } \\
\mathrm{J}_{\mathrm{IC}}(0.15) \\
\Delta \mathrm{a}(\mathrm{J} \mathrm{IC}) \\
\text { T Average } \\
\text { KjC }\end{array}$ & $\begin{array}{l}\mathbf{J}=\mathbf{C}(\Delta \mathbf{a})^{\mathbf{n}} \\
: 1443.94 \mathrm{~kJ} / \mathrm{m}^{2} \\
: 0.9941 \\
: 1648.9 \mathrm{~kJ} / \mathrm{m}^{2} \\
: 1.339 \mathrm{~mm} \\
: 636.6 \\
: 1601.9 \mathrm{~kJ} / \mathrm{m}^{2} \\
: 1.256 \mathrm{~mm} \\
: 644.3 \\
: 691.5 \mathrm{MPa}-\mathrm{m}^{0.5}\end{array}$ & $\begin{array}{l}\text { Exponent } n \\
(10 \text { Data Points) } \\
\left(9415.6 \text { in.-lb/in. }{ }^{2}\right) \\
(0.0527 \text { in.) } \\
\left(\mathrm{J}_{\mathrm{IC}} \text { at } 0.20\right) \\
\left(9146.9 \text { in. }-\mathrm{lb} / \mathrm{in}^{2}{ }^{2}\right) \\
(0.0495 \text { in.) } \\
\left(\mathrm{J}_{\mathrm{IC}} \text { at } 0.15\right)\end{array}$ & 0.4551 \\
\hline
\end{tabular}

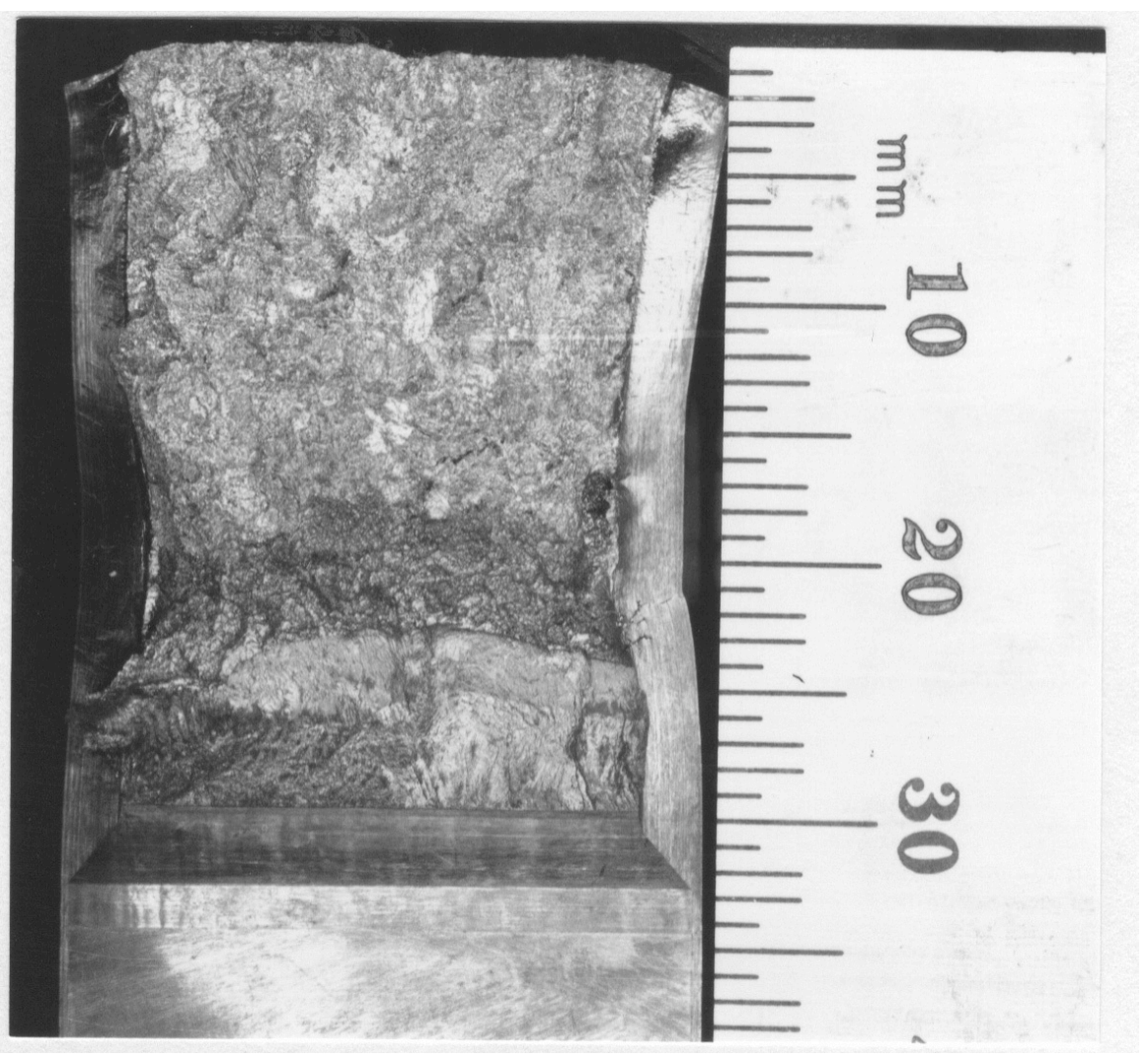

Figure C-32. Fracture surface of recovery-annealed material from the pump volute $P V$ tested at room temperature 


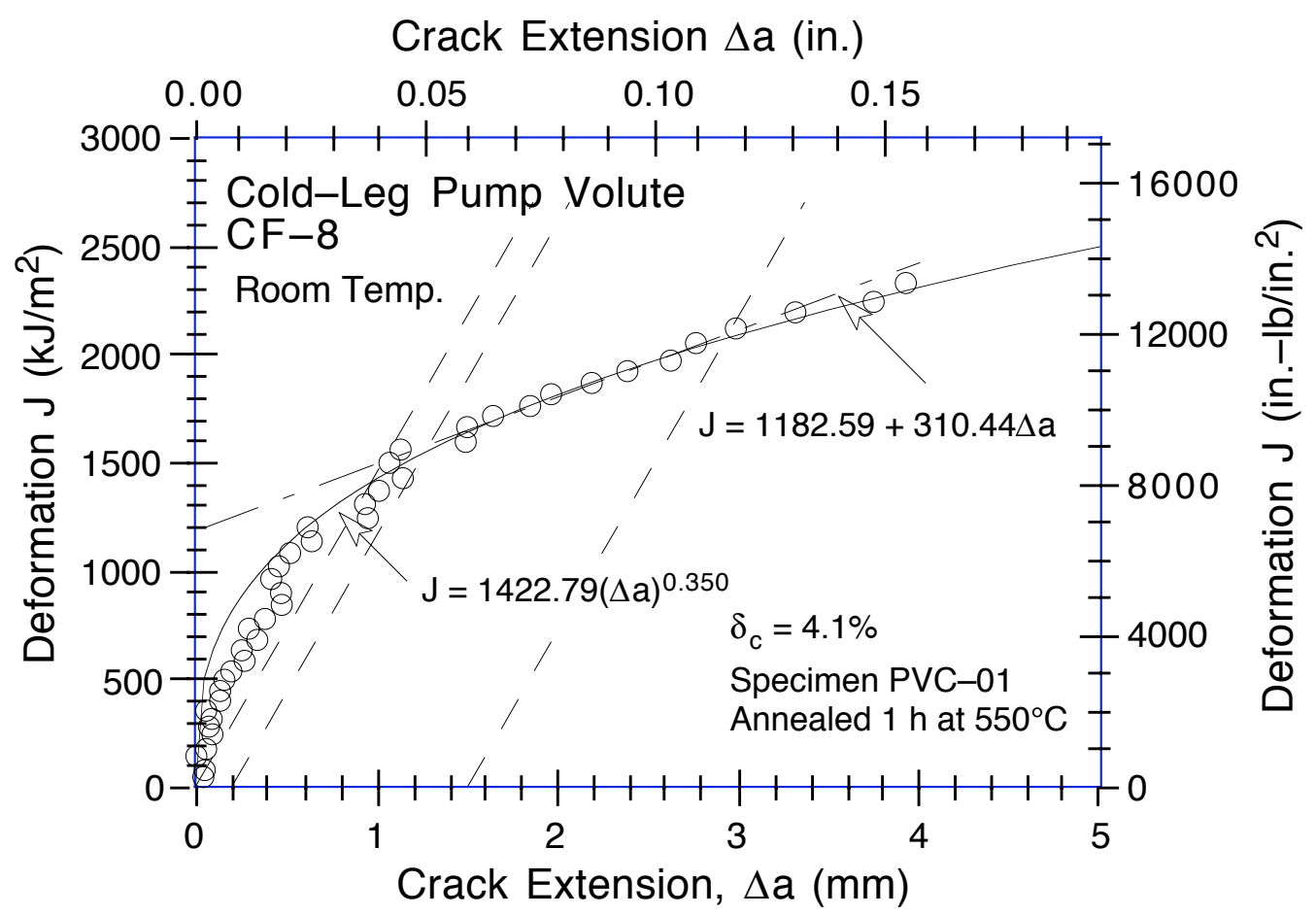

Figure $C-33$. Deformation $J-R$ Curve at room temperature for recovery-annealed material PV from the cold-leg pump volute

Crack Extension $\Delta$ a (in.)

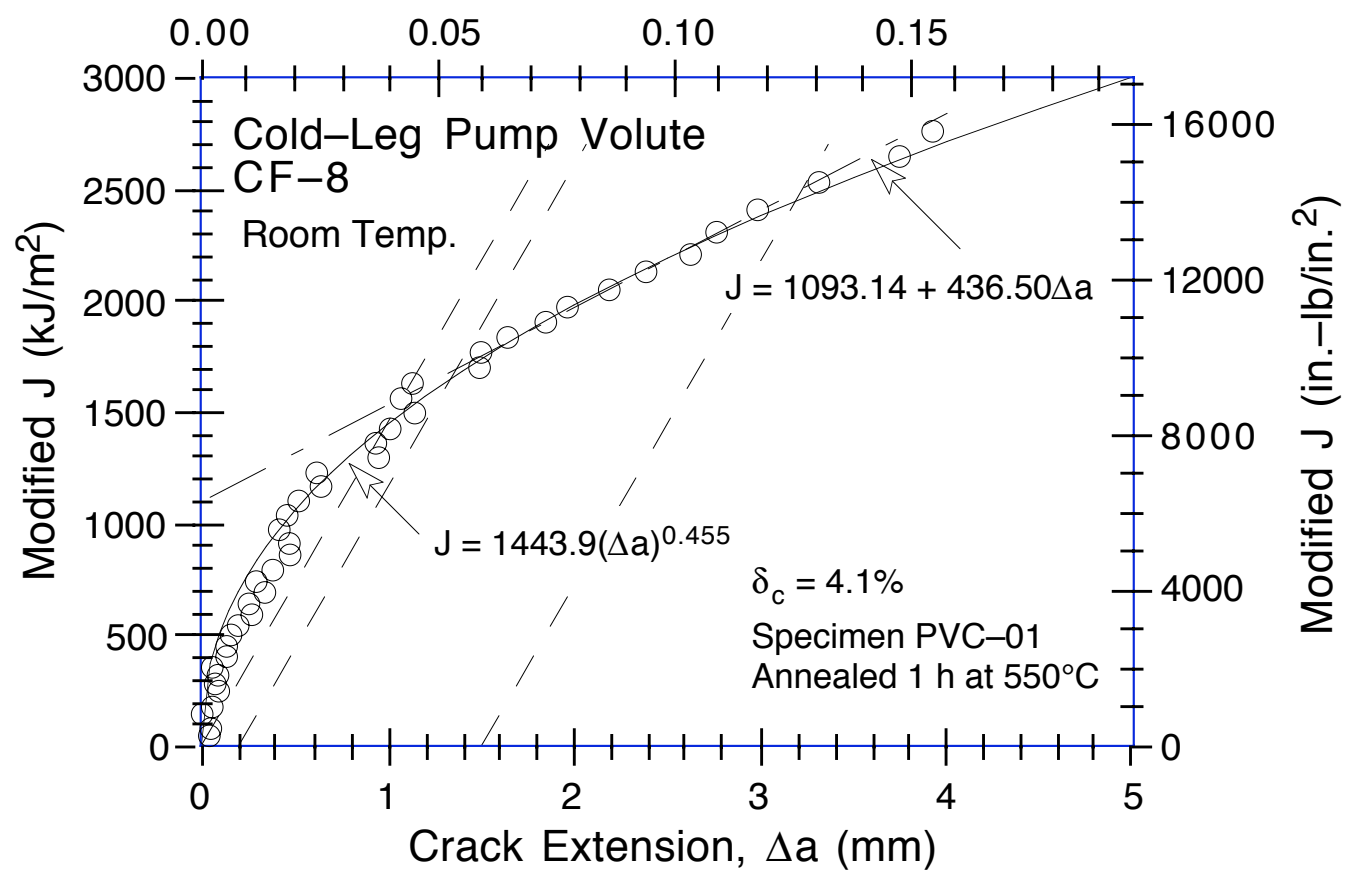

Figure $C-34$. Modified $J-R$ Curve at room temperature for recovery-annealed material PV from the cold-leg pump volute 


\begin{tabular}{|c|c|c|c|c|c|}
\hline $\begin{array}{l}\text { Test Nun } \\
\text { Material } \\
\text { Aging Te } \\
\text { Spec. Th } \\
\text { Spec. Wi }\end{array}$ & $\begin{array}{l}\text { oer } \\
\text { ype } \\
\text { ip. } \\
\text { kness } \\
\text { th }\end{array}$ & $\begin{array}{l}\mathrm{mm} \\
\mathrm{mm}\end{array}$ & $\begin{array}{l}\text { Test } \\
\text { Heat } \\
\text { Aging } \\
\text { Net T } \\
\text { Flow }\end{array}$ & $\begin{array}{l}: 2 \\
: P \\
: 1\end{array}$ & $\begin{array}{l}900 \mathrm{~h} \\
3 \mathrm{~mm} \\
0 \mathrm{MPa}\end{array}$ \\
\hline $\begin{array}{c}\text { Unload } \\
\text { Number }\end{array}$ & $\begin{array}{c}J_{d} \\
\left(k J / m^{2}\right)\end{array}$ & $\begin{array}{c}J_{m} \\
\left(k J / m^{2}\right)\end{array}$ & $\begin{array}{c}\Delta \mathrm{a} \\
(\mathrm{mm})\end{array}$ & $\begin{array}{l}\text { Load } \\
(\mathrm{kN})\end{array}$ & $\begin{array}{c}\text { Deflection } \\
(\mathrm{m} \mathrm{m})\end{array}$ \\
\hline 1 & 19.97 & 20.00 & 0.0421 & 21.619 & 0.304 \\
\hline 2 & 67.85 & 67.83 & 0.0285 & 26.041 & 0.709 \\
\hline 3 & 121.31 & 121.58 & 0.0767 & 28.076 & 1.110 \\
\hline 4 & 177.33 & 178.10 & 0.1294 & 29.502 & 1.508 \\
\hline 5 & 252.03 & 252.83 & 0.1316 & 30.969 & 2.010 \\
\hline 6 & 330.74 & 331.08 & 0.1059 & 32.142 & 2.512 \\
\hline 7 & 410.63 & 412.00 & 0.1514 & 33.355 & 3.010 \\
\hline 8 & 502.26 & 504.42 & 0.1792 & 34.233 & 3.561 \\
\hline 9 & 580.69 & 581.91 & 0.1507 & 35.162 & 4.012 \\
\hline 10 & 661.33 & 671.97 & 0.4002 & 36.040 & 4.511 \\
\hline 11 & 753.77 & 760.82 & 0.3170 & 36.963 & 5.010 \\
\hline 12 & 849.14 & 854.47 & 0.2815 & 37.779 & 5.511 \\
\hline 13 & 933.72 & 951.38 & 0.5102 & 38.475 & 6.012 \\
\hline 14 & 1027.05 & 1048.38 & 0.5717 & 39.173 & 6.516 \\
\hline 15 & 1118.30 & 1146.63 & 0.6791 & 39.605 & 7.011 \\
\hline 16 & 1205.51 & 1251.28 & 0.9250 & 40.000 & 7.525 \\
\hline 17 & 1298.08 & 1349.06 & 0.9929 & 40.498 & 8.009 \\
\hline 18 & 1401.51 & 1456.23 & 1.0380 & 40.880 & 8.526 \\
\hline 19 & 1487.90 & 1559.14 & 1.2240 & 41.053 & 9.009 \\
\hline 20 & 1579.49 & 1666.58 & $\begin{array}{l}1.3910 \\
\text {. }\end{array}$ & 41.207 & 9.515 \\
\hline 21 & 1676.72 & 1771.80 & 1.4700 & 41.424 & 10.010 \\
\hline 22 & 1765.23 & 1881.96 & 1.6717 & 41.220 & 10.515 \\
\hline 23 & 1837.73 & 1990.80 & 1.9930 & 41.089 & 11.013 \\
\hline 24 & 1922.11 & 2098.61 & 2.1895 & 40.747 & 11.514 \\
\hline 25 & 2007.88 & 2207.92 & 2.3771 & 40.524 & 12.014 \\
\hline 26 & 2085.34 & 2317.87 & 2.6238 & 40.060 & 12.515 \\
\hline 27 & 2183.06 & 2447.87 & 2.8558 & 39.802 & 13.111 \\
\hline 28 & 2261.72 & 2581.30 & 3.2302 & 39.530 & 13.715 \\
\hline 29 & 2354.79 & 2711.14 & 3.4692 & 38.755 & 14.314 \\
\hline 30 & 2430.05 & 2842.67 & 3.8180 & 37.349 & 14.917 \\
\hline 31 & 2449.81 & 2970.31 & 4.4642 & 36.075 & 15.517 \\
\hline
\end{tabular}


Table C-36. Deformation J/C and J-R curve results for specimen PVI-02

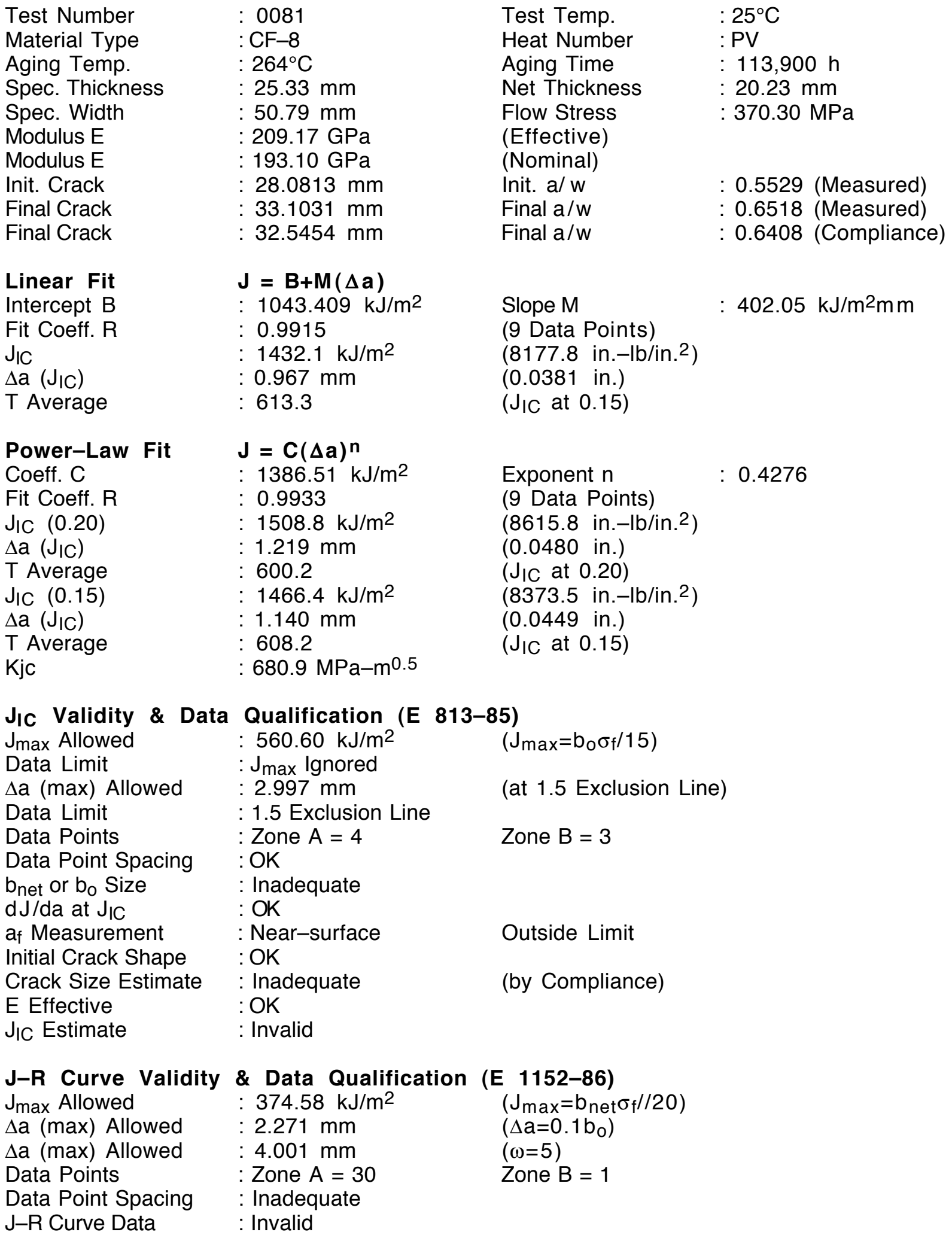


Table C-37. Modified J/C and J-R curve results for specimen PVI-02

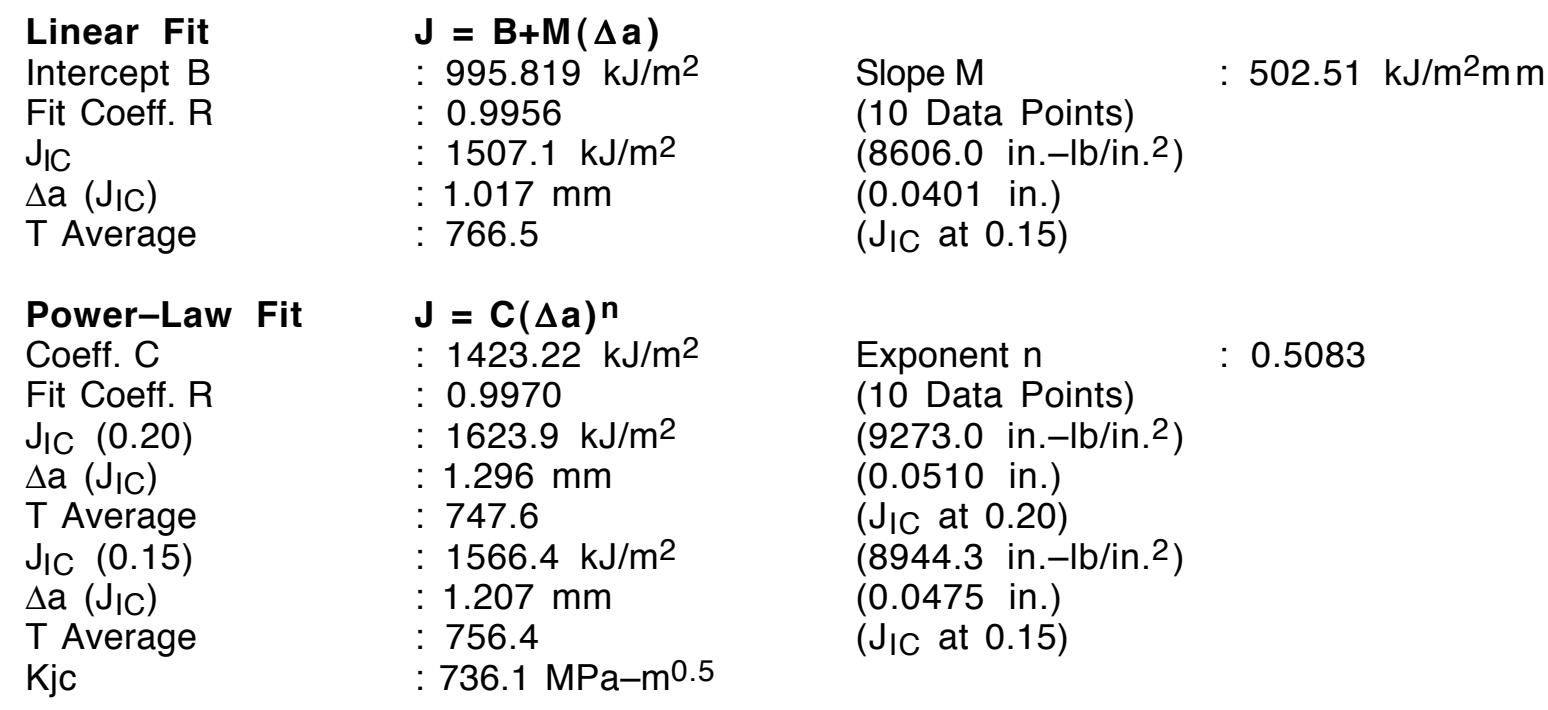

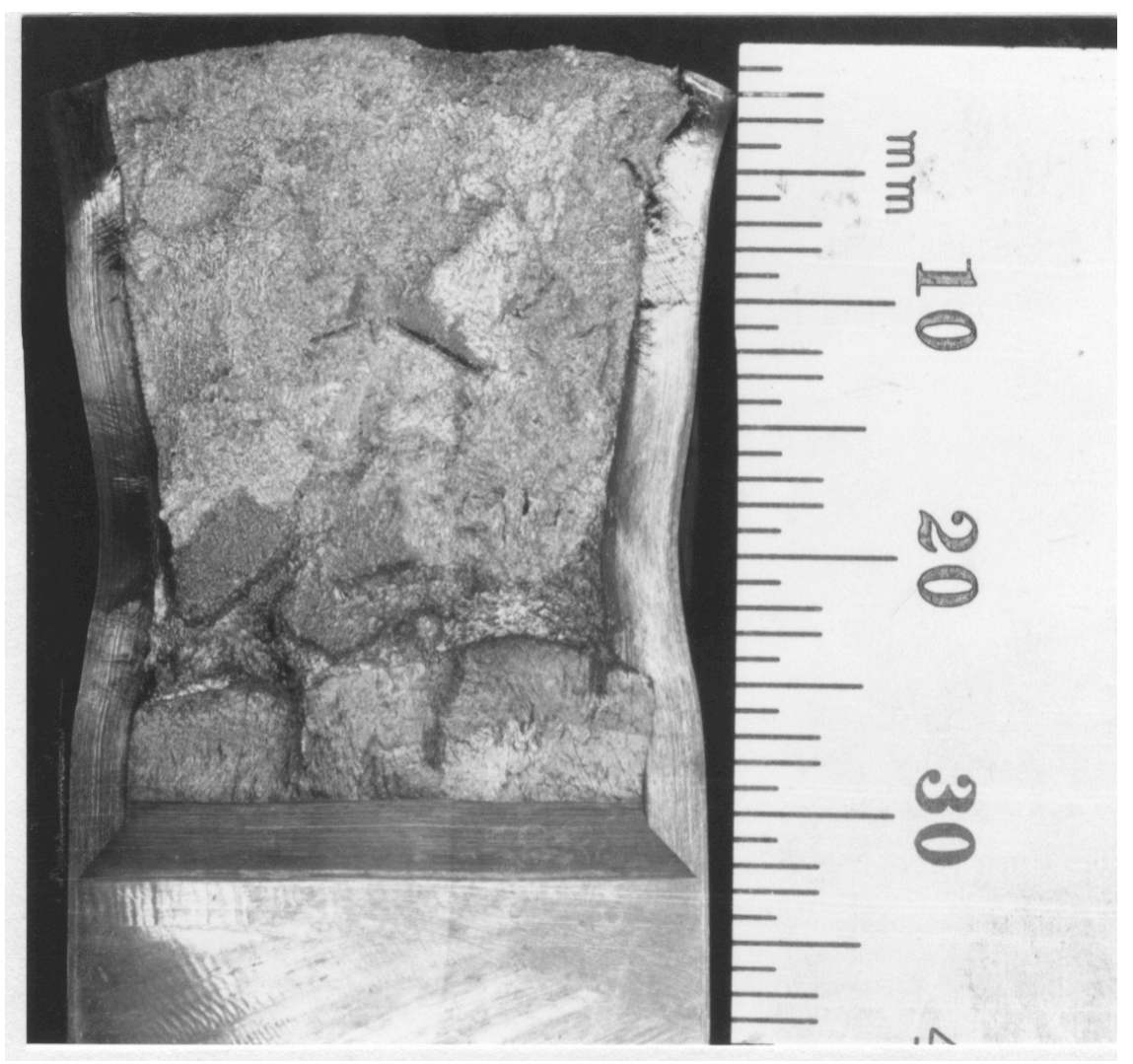

Figure C-35. Fracture surface of pump volute PV tested at room temperature after $13 y$ of service at $264^{\circ} \mathrm{C}$ 


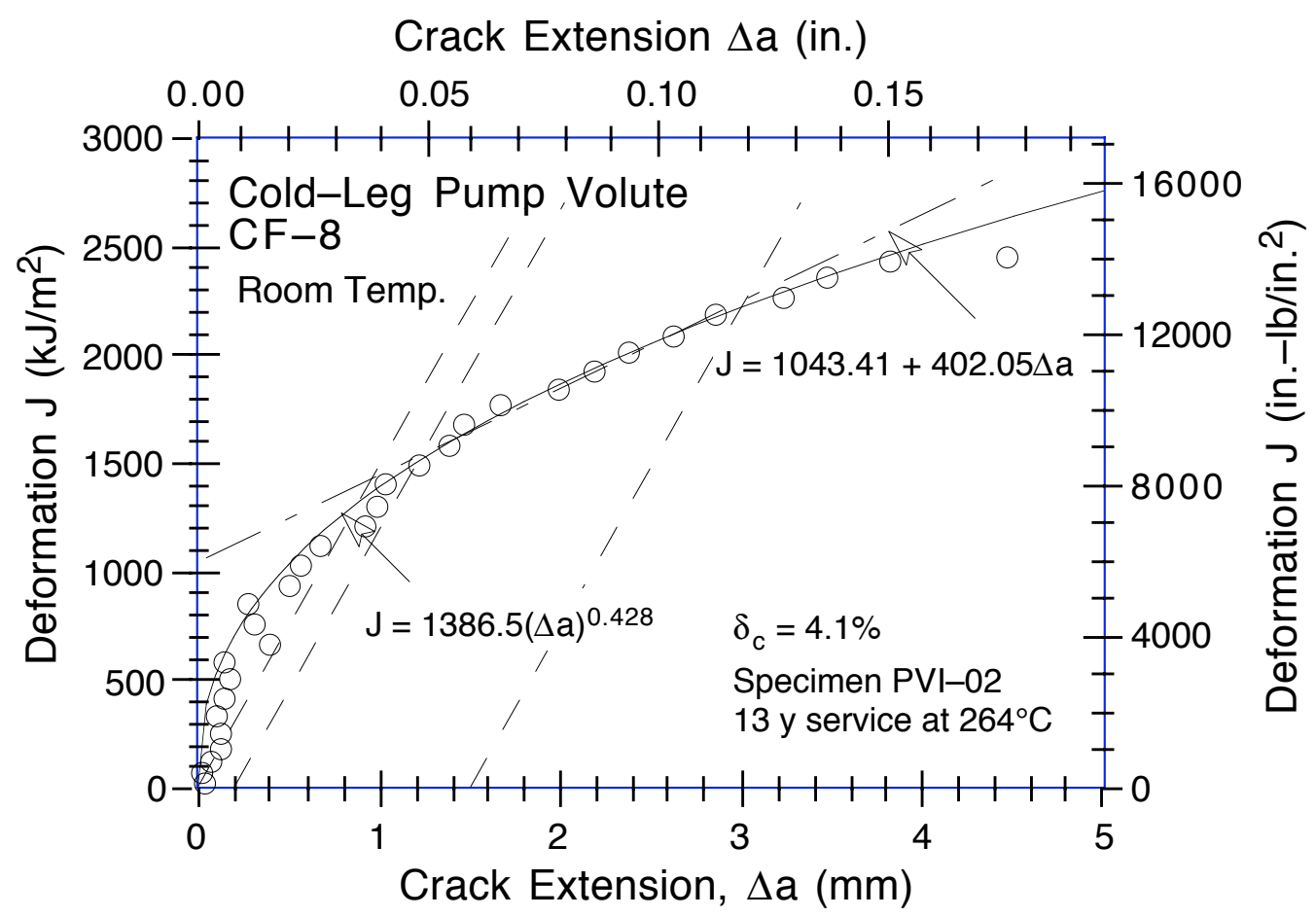

Figure $C-36$. Deformation $J-R$ Curve at room temperature for the cold-leg pump volute PV after $13 \mathrm{y}$ of service at $264^{\circ} \mathrm{C}$

Crack Extension $\Delta$ a (in.)

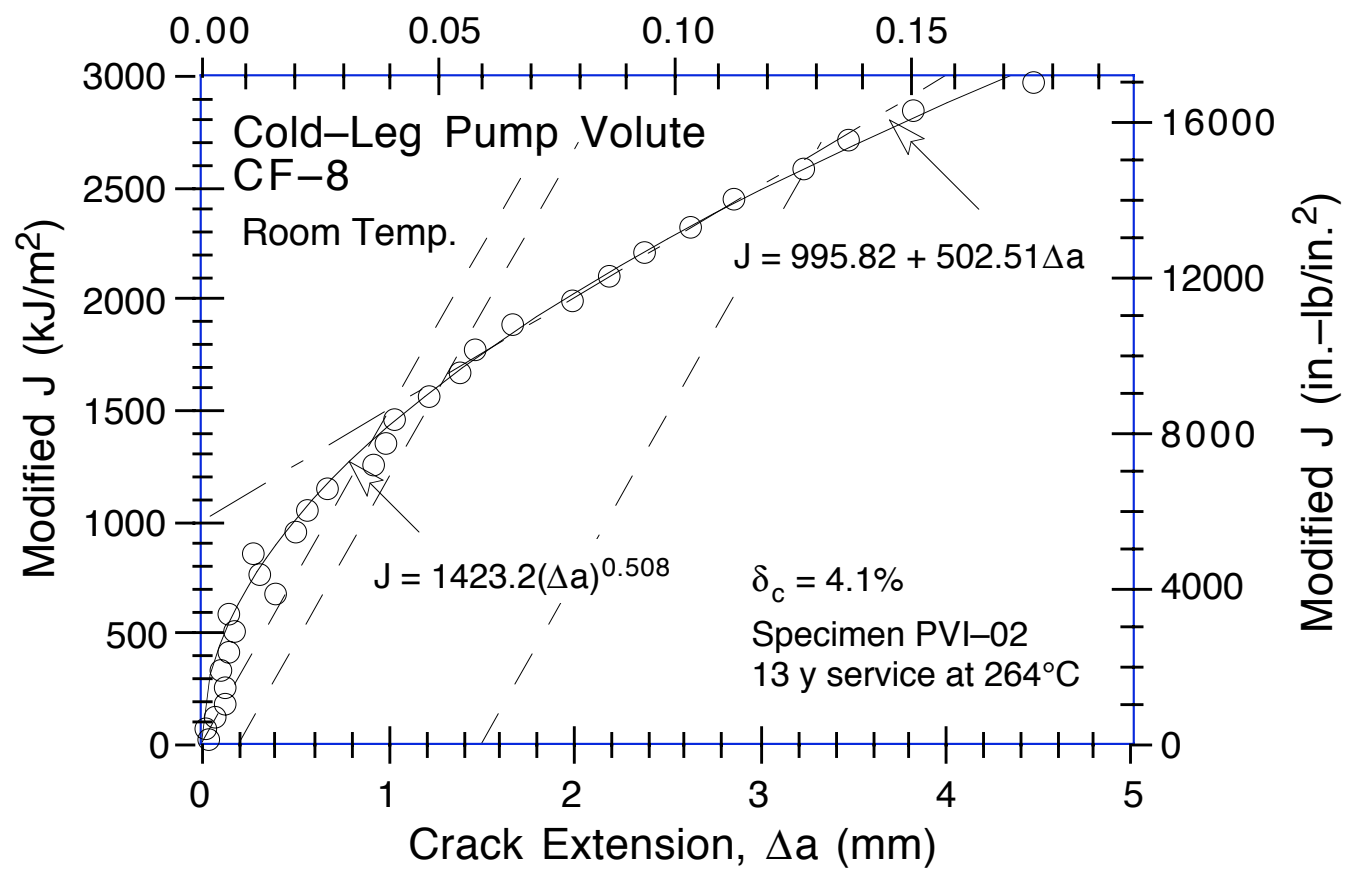

Figure $C-37$. Modified $\mathrm{J}-R$ Curve at room temperature for the cold-leg pump volute PV after $13 y$ of service at $264^{\circ} \mathrm{C}$ 
Table C-38. Test data for specimen PVO-01

\begin{tabular}{|c|c|c|c|c|c|}
\hline $\begin{array}{l}\text { Test Nun } \\
\text { Material } \\
\text { Aging Te } \\
\text { Spec. Th } \\
\text { Spec. Wi }\end{array}$ & $\begin{array}{l}\text { yer } \\
\text { ype } \\
\text { ip. } \\
\text { kness } \\
\text { th }\end{array}$ & $\begin{array}{l}\mathrm{mm} \\
\mathrm{mm}\end{array}$ & $\begin{array}{l}\text { Test } \\
\text { Heat } \\
\text { Aging } \\
\text { Net T } \\
\text { Flow }\end{array}$ & s & $\begin{array}{l}0 \mathrm{~h} \\
\mathrm{~mm} \\
0 \mathrm{MPa}\end{array}$ \\
\hline $\begin{array}{c}\text { Unload } \\
\text { Number }\end{array}$ & $\begin{array}{c}J_{d} \\
\left(k J / m^{2}\right)\end{array}$ & $\begin{array}{c}J_{m} \\
\left(k J / m^{2}\right)\end{array}$ & $\begin{array}{c}\Delta \mathrm{a} \\
(\mathrm{m} \mathrm{m}) \\
\end{array}$ & $\begin{array}{l}\text { Load } \\
(\mathrm{kN}) \\
\end{array}$ & $\begin{array}{c}\text { Deflection } \\
(\mathrm{m} \mathrm{m})\end{array}$ \\
\hline 1 & 12.90 & 12.87 & -0.0989 & 17.899 & 0.252 \\
\hline 2 & 39.22 & 39.41 & 0.0427 & 22.306 & 0.504 \\
\hline 3 & 75.34 & 75.72 & 0.0944 & 24.909 & 0.806 \\
\hline 4 & 114.73 & 115.18 & 0.1053 & 26.449 & 1.106 \\
\hline 5 & 156.49 & 157.00 & 0.1127 & 27.668 & 1.405 \\
\hline 6 & 185.85 & 185.59 & 0.0364 & 28.496 & 1.606 \\
\hline 7 & 215.26 & 215.90 & 0.1130 & 29.112 & 1.807 \\
\hline 8 & 244.80 & 245.72 & 0.1334 & 29.675 & 2.006 \\
\hline 9 & 282.97 & 284.09 & 0.1460 & 30.255 & 2.256 \\
\hline 10 & 321.88 & 323.68 & 0.1833 & 30.650 & 2.507 \\
\hline 11 & 360.32 & 365.70 & 0.3568 & 31.105 & 2.765 \\
\hline 12 & 398.53 & 403.77 & 0.3509 & 31.496 & 3.006 \\
\hline 13 & 427.96 & 438.15 & 0.5490 & 31.531 & 3.208 \\
\hline 14 & 461.09 & 470.07 & 0.5042 & 31.725 & 3.410 \\
\hline 15 & 491.93 & 503.91 & 0.6079 & 31.979 & 3.607 \\
\hline 16 & 525.08 & 536.65 & 0.5951 & 31.767 & 3.807 \\
\hline 17 & 550.18 & 572.22 & 0.9135 & 31.846 & 4.008 \\
\hline 18 & 579.72 & 604.27 & 0.9856 & 31.684 & 4.209 \\
\hline 19 & 610.51 & 638.06 & 1.0669 & 31.878 & 4.408 \\
\hline 20 & 639.14 & 672.70 & 1.2216 & 31.634 & 4.609 \\
\hline 21 & 666.00 & 707.15 & 1.4077 & 31.866 & 4.810 \\
\hline 22 & 695.24 & 740.67 & 1.5076 & 31.969 & 5.008 \\
\hline 23 & 730.38 & 775.11 & 1.4919 & 31.982 & 5.211 \\
\hline 24 & 767.73 & 819.40 & 1.6374 & 32.137 & 5.457 \\
\hline 25 & 807.18 & 863.21 & 1.7238 & 32.029 & 5.708 \\
\hline 26 & 853.48 & 916.72 & 1.8585 & 32.165 & 6.008 \\
\hline 27 & 892.89 & 970.58 & 2.1130 & 31.968 & 6.306 \\
\hline 28 & 939.47 & 1023.04 & 2.2110 & 31.896 & 6.608 \\
\hline 29 & 983.12 & 1077.41 & 2.3800 & 31.585 & 6.908 \\
\hline 30 & 1030.26 & 1130.42 & 2. 4681 & 31.705 & 7.207 \\
\hline 31 & 1072.87 & 1185.44 & 2.6452 & 31.472 & 7.508 \\
\hline 32 & 1114.38 & 1239.67 & 2.8187 & 31.236 & 7.809 \\
\hline 33 & 1155.01 & 1293.66 & 2.9930 & 31.021 & 8.108 \\
\hline 34 & 1192.22 & 1347.81 & 3.2048 & 30.361 & 8.409 \\
\hline 35 & 1237.58 & 1419.77 & 3.5206 & 29.834 & 8.809 \\
\hline 36 & 1283.48 & 1490.15 & 3.7970 & 28.670 & 9.212 \\
\hline 37 & 1320.09 & 1558.41 & 4.1389 & 27.991 & 9.607 \\
\hline 38 & 1355.90 & 1626.03 & 4.4678 & 26.883 & 10.007 \\
\hline 39 & 1380.18 & 1710.38 & 5.0614 & 25.863 & 10.507 \\
\hline 40 & 1421.27 & 1789.79 & 5.4222 & 24.859 & 11.007 \\
\hline 41 & 1466.12 & 1871.65 & 5.7544 & 24.462 & 11.510 \\
\hline 42 & 1517.84 & 1954.33 & 6.0188 & 23.795 & 12.027 \\
\hline 43 & 1552.82 & 2032.65 & 6.3740 & 23.278 & 12.506 \\
\hline 44 & 1592.69 & 2112.30 & 6.6861 & 22.484 & 13.007 \\
\hline 45 & 1621.37 & 2191.77 & 7.0693 & 21.625 & 13.510 \\
\hline 46 & 1663.40 & 2267.60 & 7.3142 & 21.101 & 14.007 \\
\hline 47 & 1686.55 & 2361.42 & 7.8046 & 19.948 & 14.607 \\
\hline 48 & 1707.56 & 2449.31 & 8.2506 & 19.101 & 15.207 \\
\hline
\end{tabular}


Table C-39. Deformation J/C and J-R curve results for specimen PVO-01

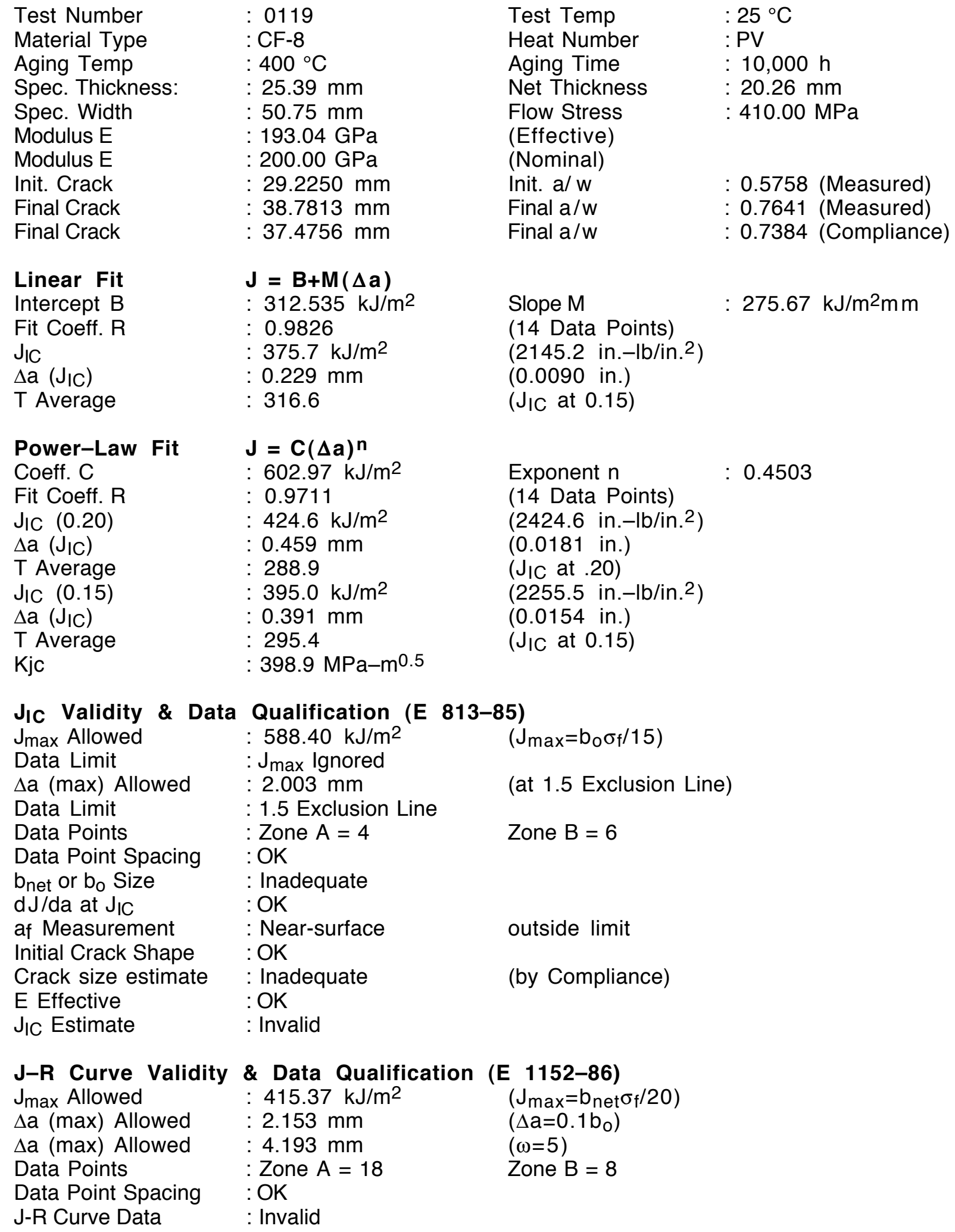


Table C-40. Modified J/C and $\mathrm{J}-R$ curve results for specimen PVO-01

\begin{tabular}{|c|c|c|c|}
\hline $\begin{array}{l}\text { Linear Fit } \\
\text { Intercept B } \\
\text { Fit Coeff. R } \\
J_{I C} \\
\Delta \text { a (JIC) } \\
\text { T Average }\end{array}$ & $\begin{array}{l}\mathbf{J}=\mathbf{B}+\mathbf{M}(\Delta \mathbf{a}) \\
: 300.136 \mathrm{~kJ} / \mathrm{m}^{2} \\
: 0.9857 \\
: 371.4 \mathrm{~kJ} / \mathrm{m}^{2} \\
: 0.226 \mathrm{~mm} \\
: 361.3\end{array}$ & $\begin{array}{l}\text { Slope } M \\
(14 \text { Data Points }) \\
\left(2120.7 \text { in. }-\mathrm{lb} / \text { in. }^{2}\right) \\
(0.0089 \text { in. }) \\
\left(J_{I C} \text { at } 0.15\right)\end{array}$ & : $314.63 \mathrm{~kJ} / \mathrm{m}^{2} \mathrm{~mm}$ \\
\hline $\begin{array}{l}\text { Power-Law Fit } \\
\text { Coeff. C } \\
\text { Fit Coeff. R } \\
\mathrm{J}_{\mathrm{IC}}(0.20) \\
\Delta \mathrm{a}\left(\mathrm{J}_{\mathrm{IC}}\right) \\
\text { T Average } \\
\mathrm{J}_{\mathrm{IC}}(0.15) \\
\Delta \mathrm{a}\left(\mathrm{J}_{\mathrm{IC}}\right) \\
\text { T Average } \\
\text { Kjc }\end{array}$ & $\begin{array}{l}\mathbf{J}=\mathbf{C}(\Delta \mathbf{a})^{\mathbf{n}} \\
: 630.46 \mathrm{~kJ} / \mathrm{m}^{2} \\
: 0.9756 \\
: 432.4 \mathrm{~kJ} / \mathrm{m}^{2} \\
: 0.464 \mathrm{~mm} \\
: 327.6 \\
: 398.8 \mathrm{~kJ} / \mathrm{m}^{2} \\
: 0.393 \mathrm{~mm} \\
: 334.5 \\
: 415.8 \mathrm{MPa}-\mathrm{m}^{0.5}\end{array}$ & $\begin{array}{l}\text { Exponent } n \\
(14 \text { Data Points) } \\
\left(2469.0 \text { in.-lb/in. }{ }^{2}\right) \\
(0.0183 \text { in.) } \\
\left(\mathrm{J}_{\mathrm{IC}} \text { at } 0.20\right) \\
\left(2277.1 \text { in. }-\mathrm{lb} / \mathrm{in}^{2}{ }^{2}\right) \\
(0.0155 \text { in.) } \\
\left(\mathrm{J}_{I C} \text { at } 0.15\right)\end{array}$ & 0.4906 \\
\hline
\end{tabular}

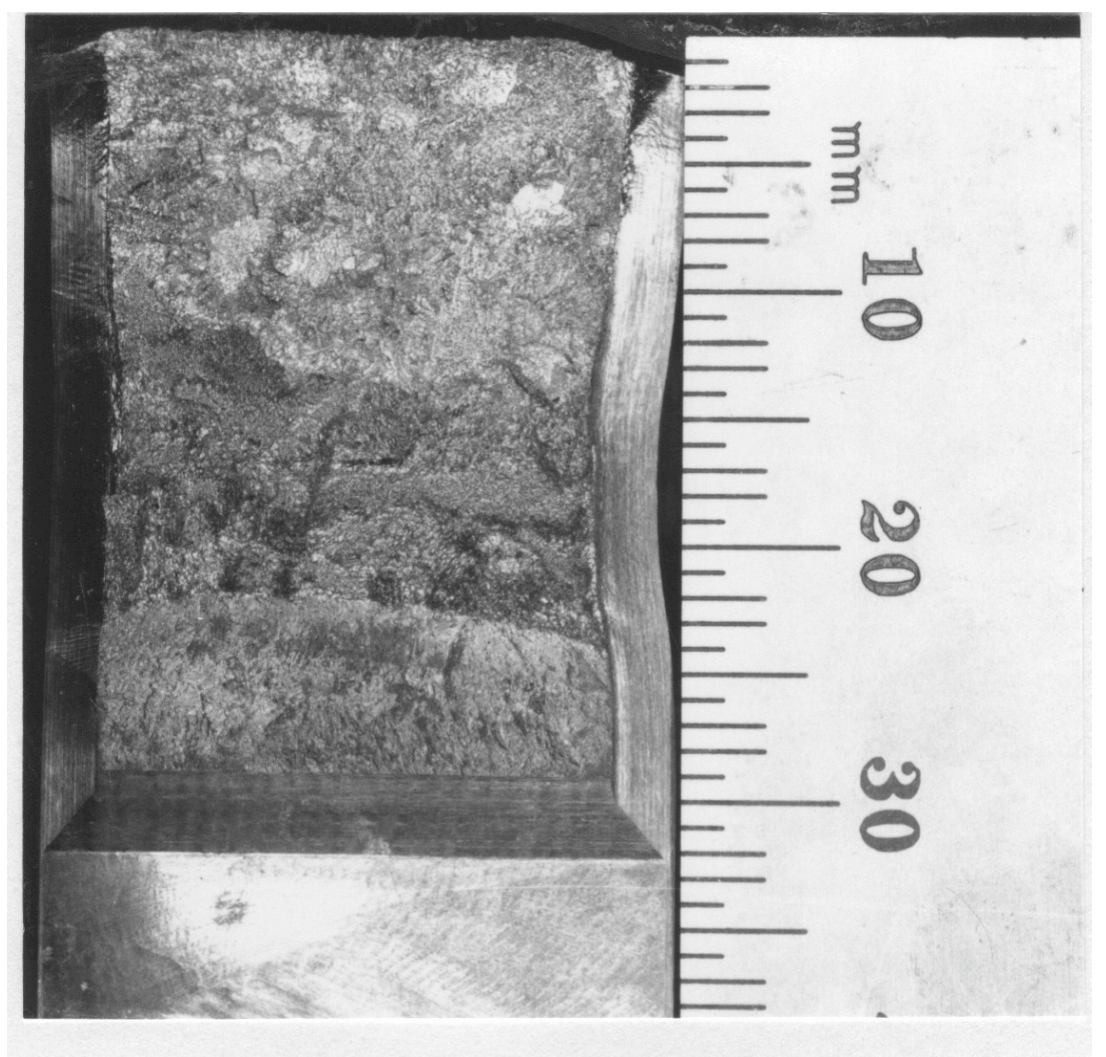

Figure C-38. Fracture surface of service-aged PV material from the pump volute aged further for $10,000 \mathrm{~h}$ at $400^{\circ} \mathrm{C}$ and tested at room temperature 


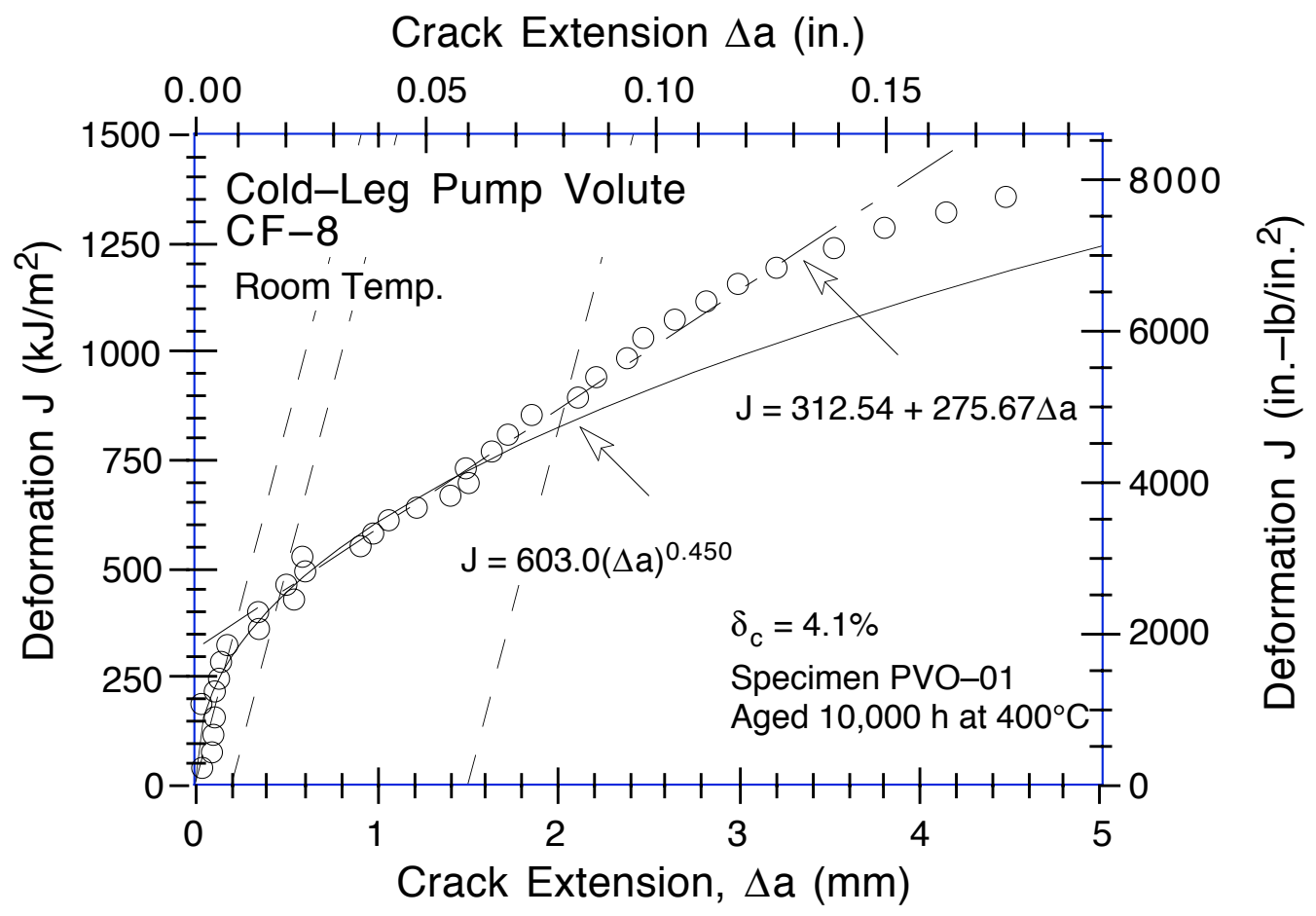

Figure $C$-39. Deformation $J-R$ Curve at room temperature for service-aged PV material from the pump volute aged further for $10,000 \mathrm{~h}$ at $400^{\circ} \mathrm{C}$

Crack Extension $\Delta$ a (in.)

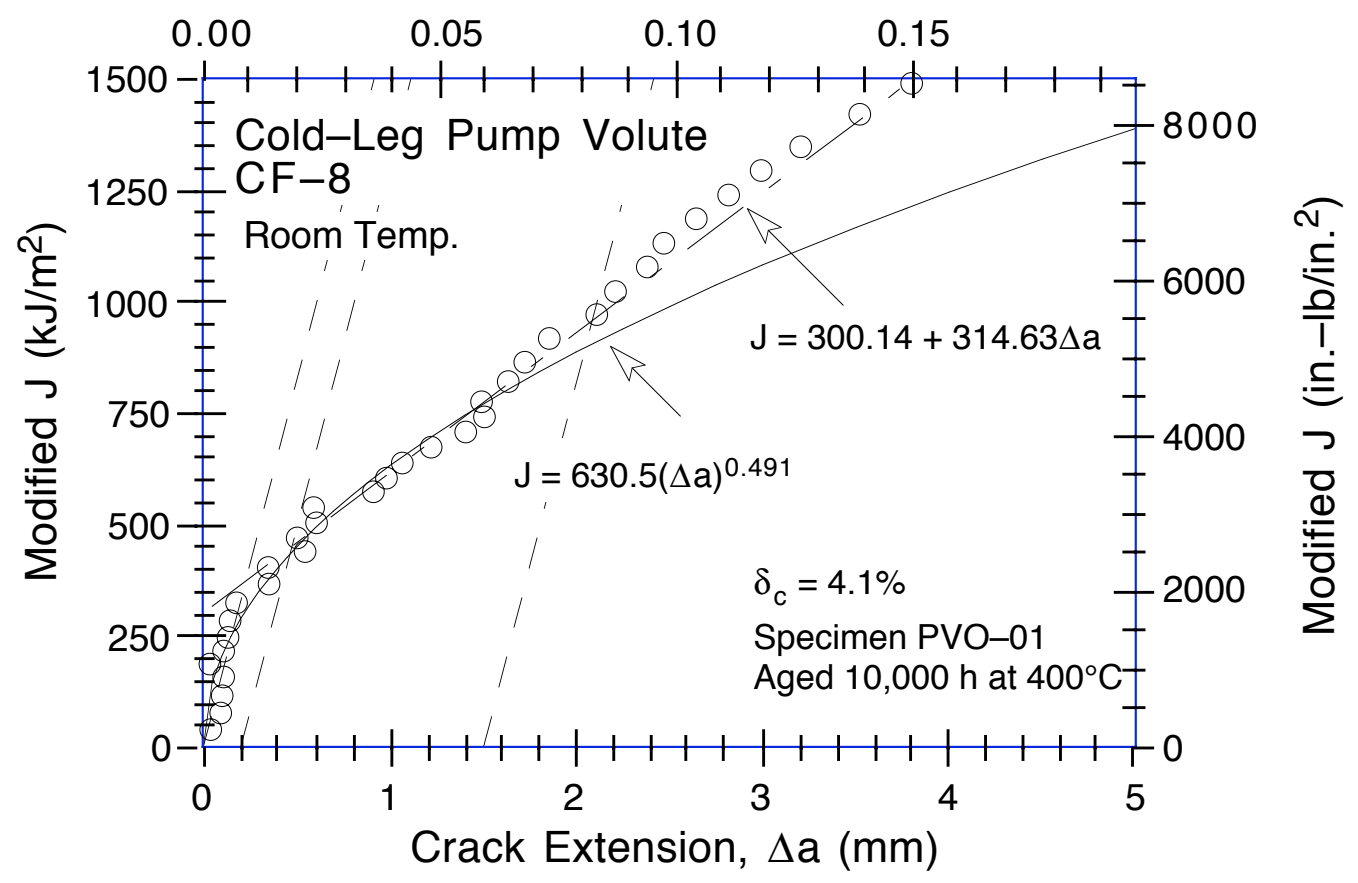

Figure $C-40$. Modified $J-R$ Curve at room temperature for service-aged $P V$ material from the pump volute aged further for $10,000 \mathrm{~h}$ at $400^{\circ} \mathrm{C}$ 
Table C-41. Test data for specimen PVI-01

\begin{tabular}{|c|c|c|c|c|c|}
\hline $\begin{array}{l}\text { Test Nun } \\
\text { Material } \\
\text { Aging Te } \\
\text { Spec. Th } \\
\text { Spec. Wi }\end{array}$ & $\begin{array}{l}\text { ber } \\
\text { ype } \\
\text { np. } \\
\text { kness } \\
\text { th }\end{array}$ & $\mathrm{mm}$ & $\begin{array}{l}\text { Test } \\
\text { Heat } \\
\text { Aging } \\
\text { Net T } \\
\text { Flow }\end{array}$ & & $9 \mathrm{~mm}$ \\
\hline $\begin{array}{c}\text { Unload } \\
\text { Number }\end{array}$ & $\begin{array}{c}J_{d} \\
\left(k J / m^{2}\right)\end{array}$ & $\begin{array}{c}J_{m} \\
\left(k J / m^{2}\right)\end{array}$ & $\begin{array}{c}\Delta \mathrm{a} \\
(\mathrm{m} \mathrm{m})\end{array}$ & $\begin{array}{l}\text { Load } \\
(\mathrm{kN})\end{array}$ & $\begin{array}{c}\text { Deflection } \\
(\mathrm{m} \mathrm{m})\end{array}$ \\
\hline 1 & 15.13 & 15.02 & -0.1850 & 14314 & 0.306 \\
\hline 2 & 37.74 & 37.88 & -0.0500 & 15.935 & 0.608 \\
\hline 3 & 69.98 & 70.75 & 0.1227 & 17.206 & 1.009 \\
\hline 4 & 104.73 & 105.39 & 0.1030 & 18.188 & 1.408 \\
\hline 5 & 142.15 & 142.29 & 0.0368 & 19.000 & 1.810 \\
\hline 6 & 180.34 & 181.06 & 0.0940 & 19.869 & 2.210 \\
\hline 7 & 220.16 & 221.18 & 0.1174 & 20.497 & 2.612 \\
\hline 8 & 265.35 & 262.07 & -0.1695 & 21.162 & 3.018 \\
\hline 9 & 302.31 & 305.23 & 0.1897 & $\begin{array}{l}21.718 \\
21.7\end{array}$ & 3.409 \\
\hline 10 & 352.24 & 346.59 & -0.2397 & 22.365 & 3.810 \\
\hline 11 & 393.18 & 393.03 & 0.0049 & 23.001 & 4.209 \\
\hline 12 & 436.99 & 441.00 & 0.1703 & 23.573 & 4.627 \\
\hline 13 & 478.10 & 485.89 & 0.3071 & $\begin{array}{l}24.043 \\
24\end{array}$ & 5.007 \\
\hline 14 & 524.44 & 534.54 & 0.3825 & 24.485 & 5.409 \\
\hline 15 & 579.19 & 583.11 & 0.1983 & 24.917 & 5.809 \\
\hline 16 & 626.43 & 634.64 & 0.3160 & 25.434 & 6.210 \\
\hline 17 & $\begin{array}{l}6<0.40 \\
684.65\end{array}$ & $\begin{array}{l}684.13 \\
684.13\end{array}$ & 0.0959 & $\begin{array}{r}25.404 \\
25.788\end{array}$ & 6.608 \\
\hline 18 & 719.86 & 737.89 & 0.5346 & 26.053 & 7.006 \\
\hline 19 & 775.72 & 792.29 & 0.5027 & 26.282 & 7.434 \\
\hline 20 & 817.41 & 843.41 & 0.6975 & 26.491 & 7.810 \\
\hline 21 & 863.97 & 897.17 & 0.8375 & 26.653 & 8.210 \\
\hline 22 & 919.98 & 951.72 & 0.8109 & 26.756 & 8.616 \\
\hline 23 & 960.19 & 1007.64 & 1.0830 & 26.747 & 9.015 \\
\hline 24 & 1019.29 & 1060.82 & 0.9862 & 26.689 & 9.414 \\
\hline 25 & 1053.10 & 1117.58 & 1.3446 & 26.552 & 9.814 \\
\hline 26 & 1084.02 & 1172.26 & 1.7008 & 26.434 & 10.212 \\
\hline 27 & 1114.29 & 1227.84 & 2.0652 & 26.360 & 10.611 \\
\hline 28 & 1167.17 & 1285.15 & $\begin{array}{l}2.1258 \\
2.1258\end{array}$ & 26.401 & 11.027 \\
\hline 29 & 1214.41 & 1340.92 & 2.2375 & 26.461 & 11.415 \\
\hline 30 & 1250.69 & 1398.35 & 2.5039 & 26.296 & 11.810 \\
\hline 31 & 1290.75 & 1454.92 & 2.7038 & 26.127 & 12.207 \\
\hline 32 & 1317.13 & 1513.99 & 3.0860 & 25.739 & 12.615 \\
\hline 33 & 1360.55 & 1585.48 & 3.3995 & 25.196 & 13.118 \\
\hline 34 & 1385.96 & 1655.34 & 3.8776 & 24.546 & 13.610 \\
\hline $\begin{array}{l}04 \\
35\end{array}$ & 1421.19 & 1725.39 & $\begin{array}{l}4.2371 \\
4.23\end{array}$ & 24.081 & 14.114 \\
\hline 36 & 1469.72 & 1794.16 & 4.4373 & 23.480 & 14.610 \\
\hline 37 & 1510.08 & 1899.77 & 5.0487 & 22.738 & 15.358 \\
\hline
\end{tabular}


Table C-42. Deformation J/C and J-R curve results for specimen PVI-01

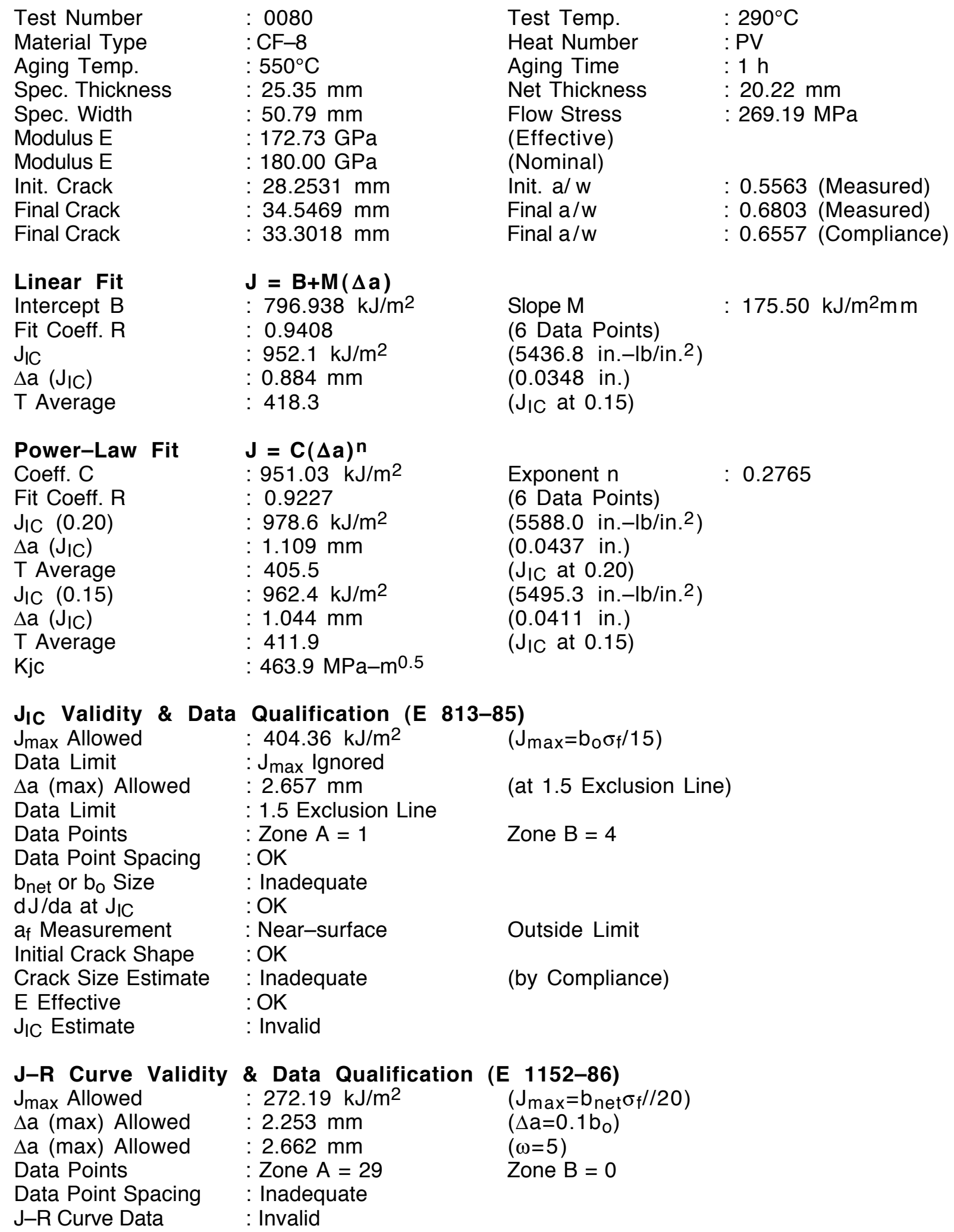


Table C-43. Modified J/C and J-R curve results for specimen PVI-01

\begin{tabular}{|c|c|c|c|}
\hline $\begin{array}{l}\text { Linear Fit } \\
\text { Intercept B } \\
\text { Fit Coeff. R } \\
J_{I C} \\
\Delta \text { a (JIC) } \\
\text { T Average }\end{array}$ & $\begin{array}{l}\mathbf{J}=\mathbf{B}+\mathbf{M}(\Delta \mathbf{a}) \\
: 657.014 \mathrm{~kJ} / \mathrm{m}^{2} \\
: 0.9799 \\
: 905.2 \mathrm{~kJ} / \mathrm{m}^{2} \\
: 0.841 \mathrm{~mm} \\
: 703.7\end{array}$ & $\begin{array}{l}\text { Slope } M \\
(6 \text { Data Points) } \\
\left(5168.9 \text { in. }-\mathrm{lb} / \text { in. }^{2}\right) \\
(0.0331 \text { in. }) \\
\left(J_{I C} \text { at } 0.15\right)\end{array}$ & $295.22 \mathrm{~kJ} / \mathrm{m}^{2} \mathrm{~mm}$ \\
\hline $\begin{array}{l}\text { Power-Law Fit } \\
\text { Coeff. C } \\
\text { Fit Coeff. R } \\
\mathrm{J}_{\mathrm{IC}}(0.20) \\
\Delta \mathrm{a}\left(\mathrm{J}_{\mathrm{IC}}\right) \\
\text { T Average } \\
\mathrm{J}_{\mathrm{IC}}(0.15) \\
\Delta \mathrm{a}\left(\mathrm{J}_{\mathrm{IC}}\right) \\
\text { T Average } \\
\text { Kjc }\end{array}$ & $\begin{array}{l}\mathbf{J}=\mathbf{C}(\Delta \mathbf{a})^{\mathbf{n}} \\
: 892.04 \mathrm{~kJ} / \mathrm{m}^{2} \\
: 0.9750 \\
: 912.4 \mathrm{~kJ} / \mathrm{m}^{2} \\
: 1.047 \mathrm{~mm} \\
: 745.6 \\
: 876.1 \mathrm{~kJ} / \mathrm{m}^{2} \\
: 0.964 \mathrm{~mm} \\
: 756.0 \\
: 508.3 \mathrm{MPa}-\mathrm{m}^{0.5}\end{array}$ & $\begin{array}{l}\text { Exponent } n \\
(6 \text { Data Points) } \\
\left(5209.8 \text { in. }-\mathrm{lb} / \mathrm{in}^{2}{ }^{2}\right) \\
(0.0412 \text { in.) } \\
\left(\mathrm{J}_{\mathrm{IC}} \text { at } 0.20\right) \\
\left(5002.6 \text { in. }-\mathrm{lb} / \mathrm{in}^{2}{ }^{2}\right) \\
(0.0379 \text { in.) } \\
\left(\mathrm{J}_{\mathrm{IC}} \text { at } 0.15\right)\end{array}$ & 0.4873 \\
\hline
\end{tabular}

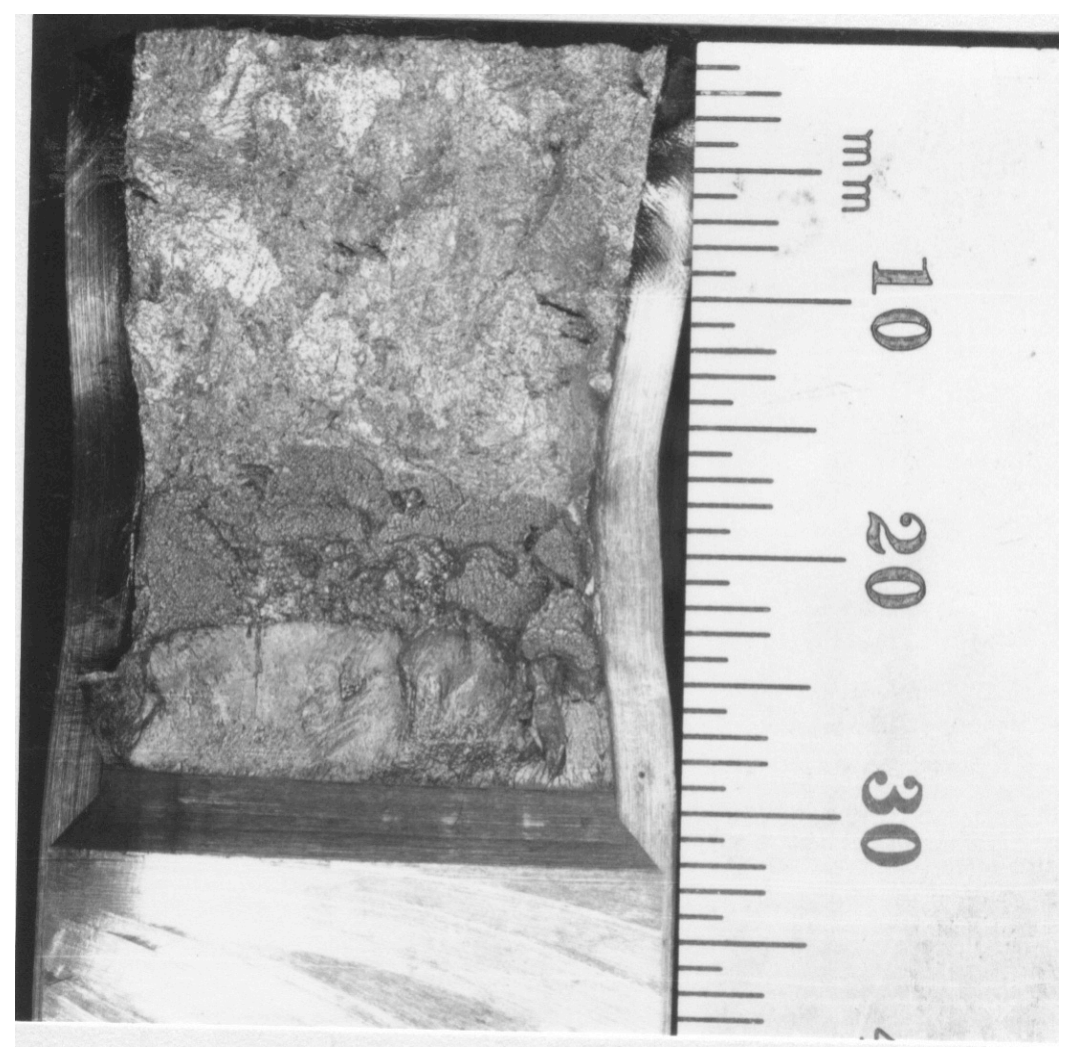

Figure C-41. Fracture surface of recovery-annealed material from the pump volute PV tested at $290^{\circ} \mathrm{C}$ 


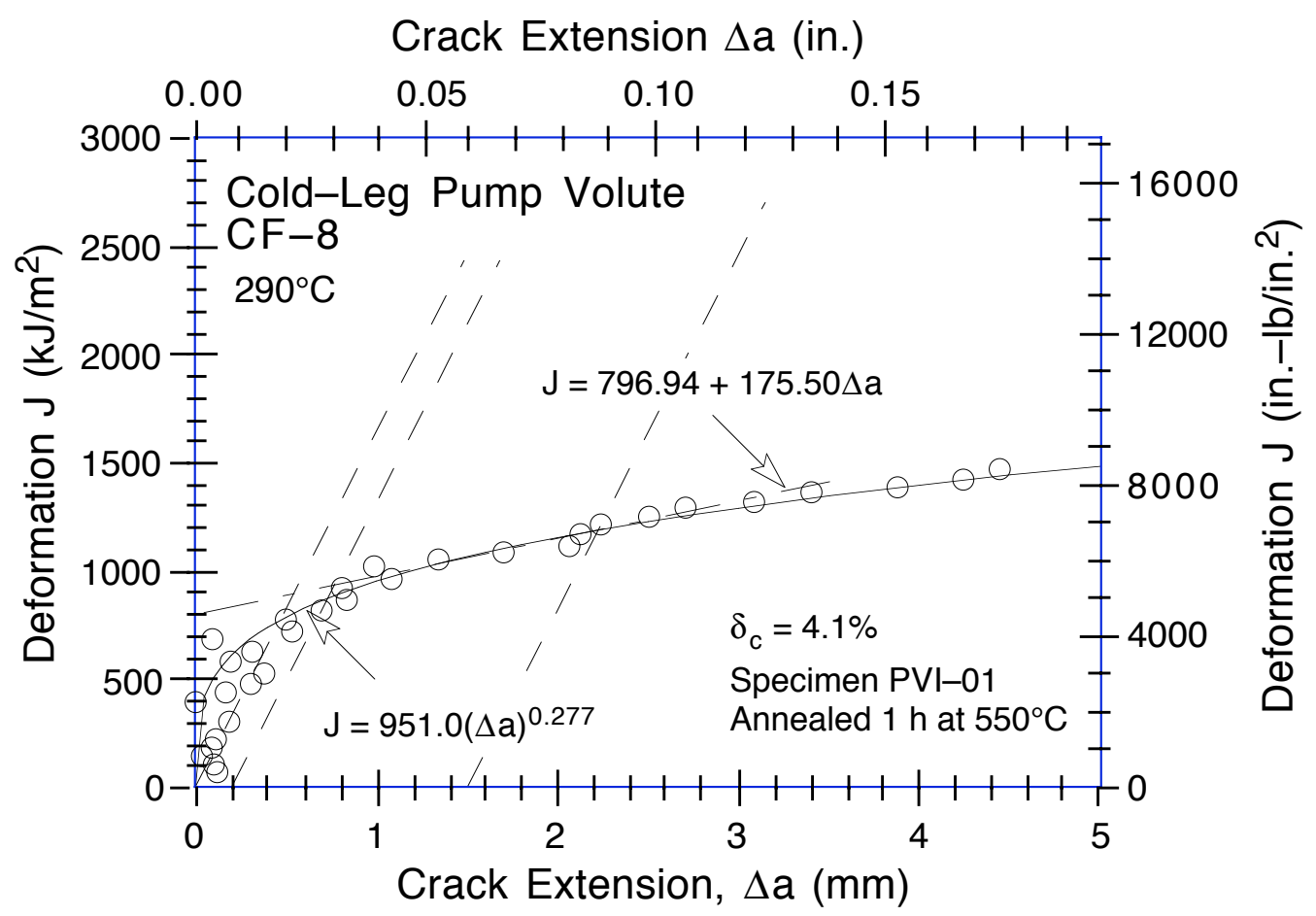

Figure C-42. Deformation $J-R$ Curve at $290^{\circ} \mathrm{C}$ for recovery-annealed material $P V$ from the pump volute

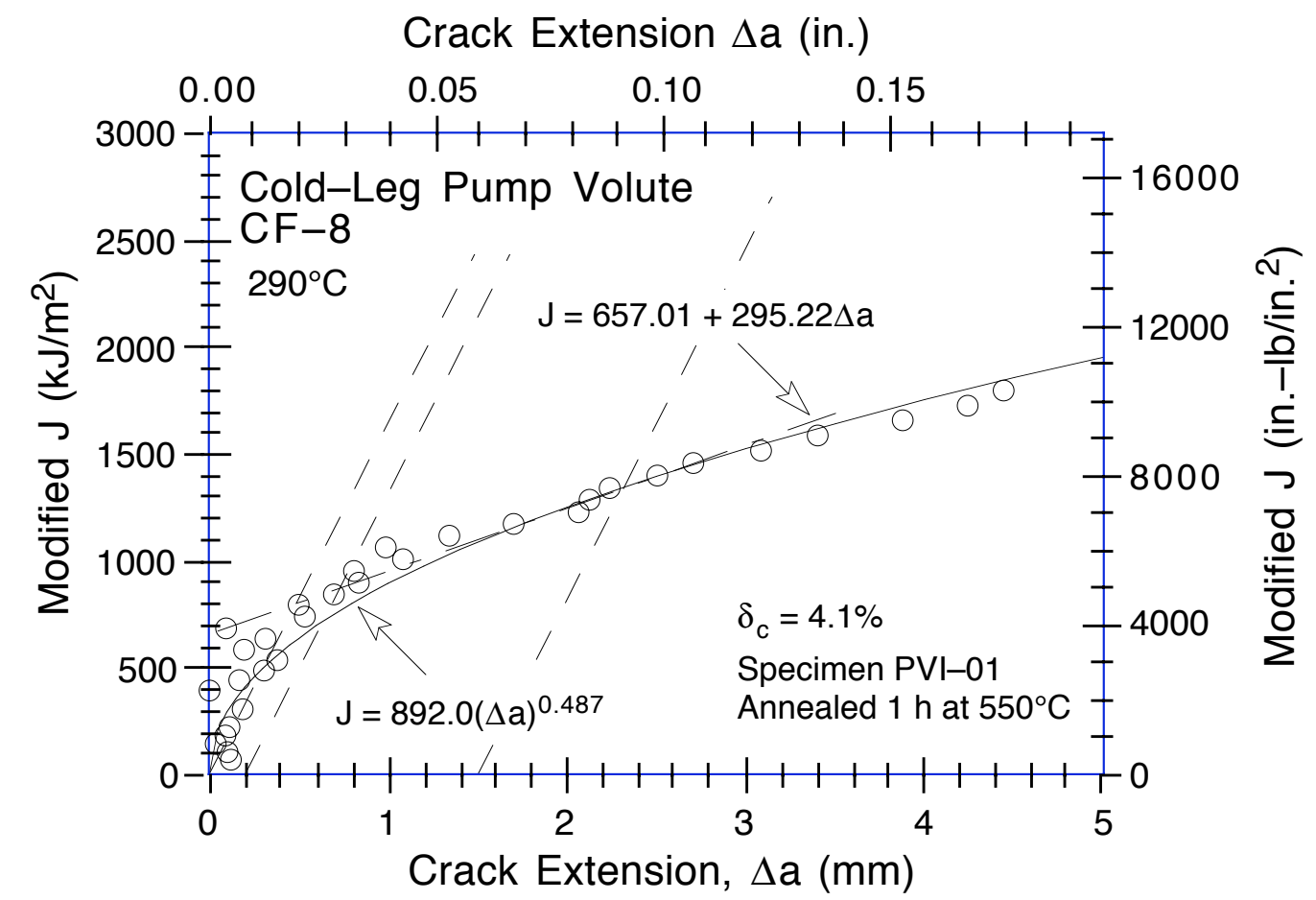

Figure C-43. Modified J-R Curve at $290^{\circ} \mathrm{C}$ for recovery-annealed material PV from the pump volute 
Table C-44. Test data for specimen PVC-02

\begin{tabular}{|c|c|c|c|c|c|}
\hline \multicolumn{2}{|c|}{$\begin{array}{l}\text { Test Number } \\
\text { Material Type } \\
\text { Aging Temp. } \\
\text { Spec. Thickness } \\
\text { Spec. Width }\end{array}$} & $\begin{array}{l}0079 \\
: C F-8 \\
264^{\circ} \mathrm{C} \\
25.37 \mathrm{~mm} \\
50.82 \mathrm{~mm}\end{array}$ & \multicolumn{2}{|c|}{$\begin{array}{l}\text { Test Temp. } \\
\text { Heat Number } \\
\text { Aging Time } \\
\text { Net Thickness } \\
\text { Flow Stress }\end{array}$} & $\begin{array}{l}: 290^{\circ} \mathrm{C} \\
: \mathrm{PV} \\
: 113,900 \mathrm{~h} \\
: 20.28 \mathrm{~mm} \\
: 265.80 \mathrm{MPa}\end{array}$ \\
\hline $\begin{array}{c}\text { Unload } \\
\text { Number }\end{array}$ & $\begin{array}{c}J_{d} \\
\left(k J / m^{2}\right)\end{array}$ & $\begin{array}{c}J_{m} \\
\left(k J / m^{2}\right)\end{array}$ & $\begin{array}{c}\Delta \mathrm{a} \\
(\mathrm{m} \mathrm{m})\end{array}$ & $\begin{array}{l}\text { Load } \\
(\mathrm{kN})\end{array}$ & $\begin{array}{c}\text { Deflection } \\
(\mathrm{m} \mathrm{m})\end{array}$ \\
\hline 1 & 7.34 & 7.35 & 0.0605 & 12.915 & 0.206 \\
\hline 2 & 21.31 & 21.11 & -0.1789 & 14.980 & 0.408 \\
\hline 3 & 41.06 & 40.63 & -0.2924 & 16.156 & 0.659 \\
\hline 4 & 61.28 & 61.75 & -0.0075 & 16.988 & 0.907 \\
\hline 5 & 82.20 & 82.91 & 0.0480 & 17.639 & 1.156 \\
\hline 6 & 104.55 & 105.26 & 0.0465 & 18.274 & 1.406 \\
\hline 7 & 132.98 & 132.79 & -0.0759 & 18.976 & 1.705 \\
\hline 8 & 162.34 & 161.84 & -0.1100 & 19.458 & 2.007 \\
\hline 9 & 191.01 & 191.79 & 0.0083 & 20.019 & 2.308 \\
\hline 10 & 223.01 & 221.28 & -0.1910 & 20.474 & 2.608 \\
\hline 11 & 249.49 & 253.70 & 0.2263 & 21.015 & 2.906 \\
\hline 12 & 283.77 & 284.08 & -0.0148 & 21.540 & 3.209 \\
\hline 13 & 313.53 & 318.22 & 0.2280 & 21.968 & 3.510 \\
\hline 14 & 346.31 & 350.61 & 0.2085 & 22.201 & 3.809 \\
\hline 15 & 376.93 & 385.42 & 0.3999 & 22.775 & 4.109 \\
\hline 16 & 413.69 & 419.62 & 0.2932 & 23.046 & 4.413 \\
\hline 17 & 442.03 & 456.30 & 0.6145 & 23.461 & 4.712 \\
\hline 18 & 483.08 & 489.98 & 0.3536 & 23.714 & 5.012 \\
\hline 19 & 514.28 & 528.75 & 0.6032 & 24.135 & 5.315 \\
\hline 20 & 531.56 & 557.24 & 0.9573 & 24.475 & 5.544 \\
\hline 21 & 557.79 & 565.04 & 0.3931 & 25.176 & 5.641 \\
\hline 22 & 596.19 & 603.86 & 0.4053 & 24.655 & 5.928 \\
\hline 23 & 636.90 & 638.98 & 0.2554 & 24.971 & 6.212 \\
\hline 24 & 666.85 & 678.24 & 0.4918 & 25.252 & 6.509 \\
\hline 25 & $\begin{array}{l}708.92 \\
708.9\end{array}$ & 716.16 & 0.3925 & 25.527 & 6.815 \\
\hline 26 & 738.92 & 756.19 & 0.6206 & 25.756 & 7.112 \\
\hline 27 & 771.85 & 795.27 & 0.7543 & 25.877 & 7.413 \\
\hline 28 & 805.95 & 834.99 & 0.8703 & 25.929 & 7.712 \\
\hline 29 & 851.09 & 873.18 & 0.7339 & 25.913 & 8.006 \\
\hline 30 & 884.78 & 931.32 & 1.1884 & 25.997 & 8.421 \\
\hline 31 & 924.15 & 967.63 & $\begin{array}{l}1.1339 \\
\end{array}$ & 25.891 & 8.708 \\
\hline 32 & 950.05 & 1009.62 & 1.4098 & 25.833 & 9.007 \\
\hline 33 & 984.01 & 1049.74 & 1.5116 & 25.821 & 9.308 \\
\hline 34 & 1006.89 & 1091.81 & 1.8173 & 25.786 & 9.608 \\
\hline 35 & 1052.24 & 1138.54 & 1.8383 & 25.881 & 9.957 \\
\hline 36 & 1081.24 & 1189.51 & 2.1601 & 25.795 & 10.312 \\
\hline 37 & 1124.38 & 1244.68 & 2.3284 & 25.931 & 10.711 \\
\hline 38 & 1177.20 & 1300.38 & $\begin{array}{l}2.3668 \\
2.0\end{array}$ & 25.854 & 11.108 \\
\hline 39 & 1211.86 & 1358.83 & 2.6712 & 25.814 & 11.508 \\
\hline 40 & 1260.20 & 1419.88 & $\begin{array}{l}2.8265 \\
\end{array}$ & 25.672 & 11.940 \\
\hline 41 & 1306.84 & 1487.79 & 3.0747 & 25.366 & 12.410 \\
\hline 42 & 1364.55 & 1558.32 & 3.2169 & 24.874 & 12.909 \\
\hline 43 & 1419.98 & 1644.08 & 3.5357 & 24.436 & 13.506 \\
\hline 44 & 1482.64 & 1744.65 & 3.9114 & 24.168 & 14.215 \\
\hline 45 & 1668.41 & 1958.27 & 4.1535 & 24.025 & 15.706 \\
\hline 46 & 1543.72 & 1953.07 & 5.2297 & 23.802 & 15.708 \\
\hline
\end{tabular}


Table C-45. Deformation JIC and $\mathrm{J}-R$ curve results for specimen PVC-02

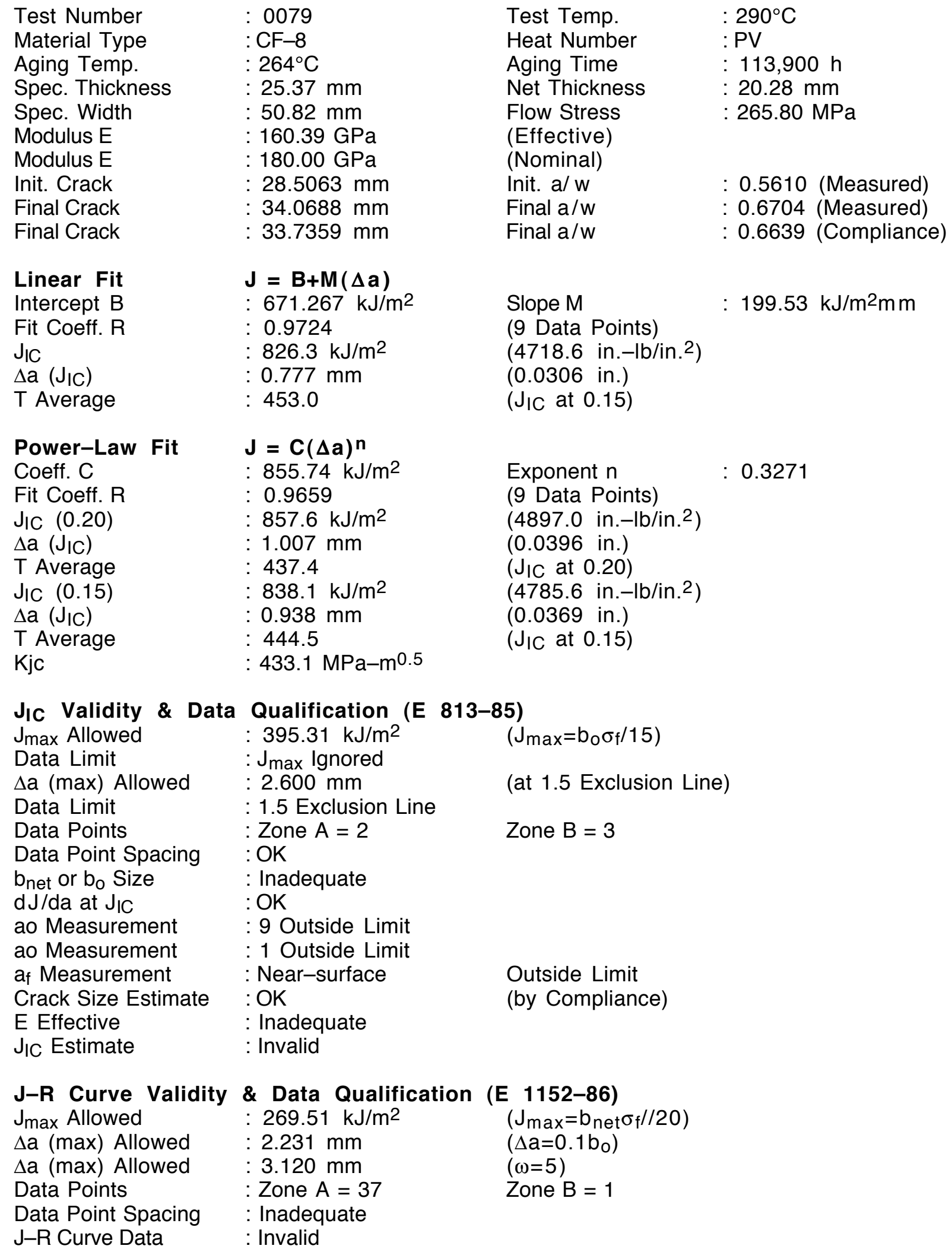


Table C-46. Modified JIC and J-R curve results for specimen PVC-02

\begin{tabular}{|c|c|c|c|}
\hline $\begin{array}{l}\text { Linear Fit } \\
\text { Intercept B } \\
\text { Fit Coeff. R } \\
J_{I C} \\
\Delta \text { a (JIC) } \\
\text { T Average }\end{array}$ & $\begin{array}{l}\mathbf{J}=\mathbf{B}+\mathbf{M}(\Delta \mathbf{a}) \\
: 622.039 \mathrm{~kJ} / \mathrm{m}^{2} \\
: 0.9909 \\
: 839.8 \mathrm{~kJ} / \mathrm{m}^{2} \\
: 0.790 \mathrm{~mm} \\
: 625.9\end{array}$ & $\begin{array}{l}\text { Slope } M \\
(11 \text { Data Points) } \\
\left(4795.5 \text { in. }-\mathrm{lb} / \text { in. }^{2}\right) \\
(0.0311 \text { in.) } \\
\left(J_{I C} \text { at } 0.15\right)\end{array}$ & $275.71 \mathrm{~kJ} / \mathrm{m}^{2} \mathrm{~mm}$ \\
\hline $\begin{array}{l}\text { Power-Law Fit } \\
\text { Coeff. C } \\
\text { Fit Coeff. R } \\
\mathrm{J}_{\mathrm{IC}}(0.20) \\
\Delta \mathrm{a}\left(\mathrm{J}_{\mathrm{IC}}\right) \\
\text { T Average } \\
\mathrm{J}_{\mathrm{IC}}(0.15) \\
\Delta \mathrm{a}\left(\mathrm{J}_{\mathrm{IC}}\right) \\
\text { T Average } \\
\text { Kjc }\end{array}$ & $\begin{array}{l}\mathbf{J}=\mathbf{C}(\Delta \mathbf{a})^{\mathbf{n}} \\
: 875.54 \mathrm{~kJ} / \mathrm{m}^{2} \\
: 0.9835 \\
: 889.3 \mathrm{~kJ} / \mathrm{m}^{2} \\
: 1.036 \mathrm{~mm} \\
: 612.9 \\
: 859.5 \mathrm{~kJ} / \mathrm{m}^{2} \\
: 0.958 \mathrm{~mm} \\
: 621.9 \\
: 468.5 \mathrm{MPa}-\mathrm{m}^{0.5}\end{array}$ & $\begin{array}{l}\text { Exponent } \mathrm{n} \\
(11 \text { Data Points) } \\
\left(5078.1 \text { in.-lb/in. }{ }^{2}\right) \\
(0.0408 \text { in.) } \\
\left(\mathrm{J}_{\mathrm{IC}} \text { at } 0.20\right) \\
\left(4907.8 \text { in. }-\mathrm{lb} / \text { in. }^{2}\right) \\
(0.0377 \text { in.) } \\
\left(\mathrm{J}_{I C} \text { at } 0.15\right)\end{array}$ & 0.4358 \\
\hline
\end{tabular}

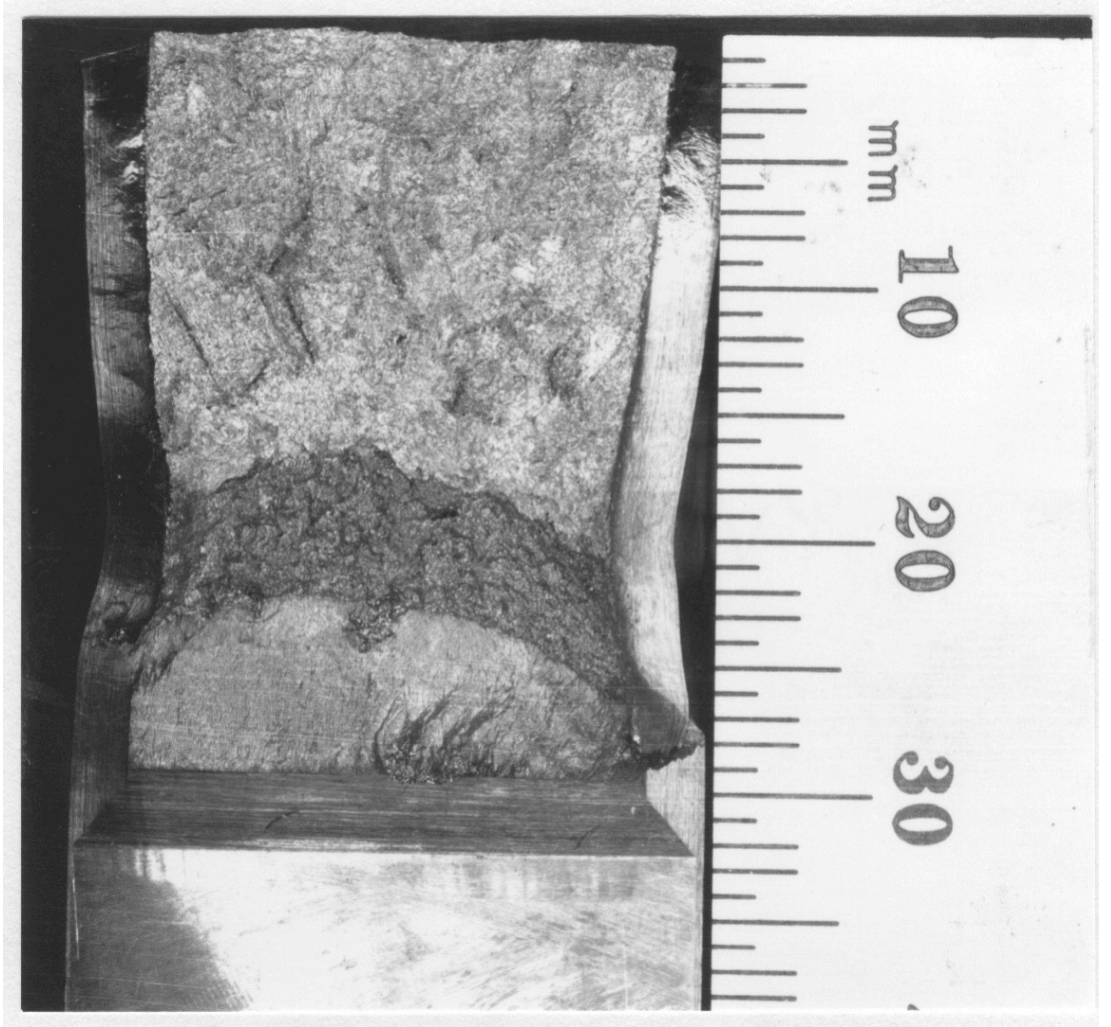

Figure C-44. Fracture surface of pump volute PV tested at $290^{\circ} \mathrm{C}$ after $13 \mathrm{y}$ of service at $264^{\circ} \mathrm{C}$ 


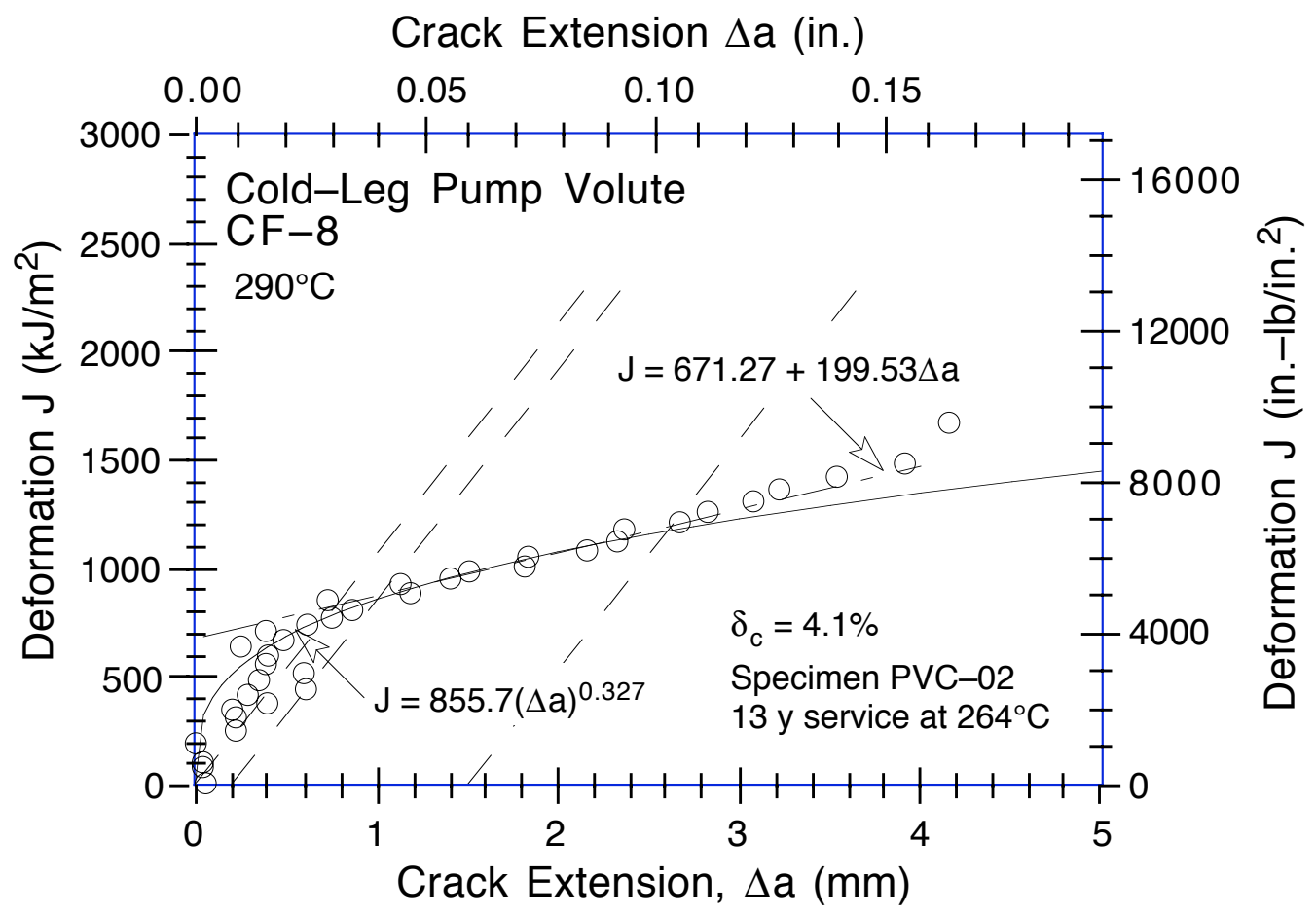

Figure C-45. Deformation J-R Curve at $290^{\circ} \mathrm{C}$ for the cold-leg pump volute PV after $13 \mathrm{y}$ of service at $264^{\circ} \mathrm{C}$

Crack Extension $\Delta \mathrm{a}$ (in.)

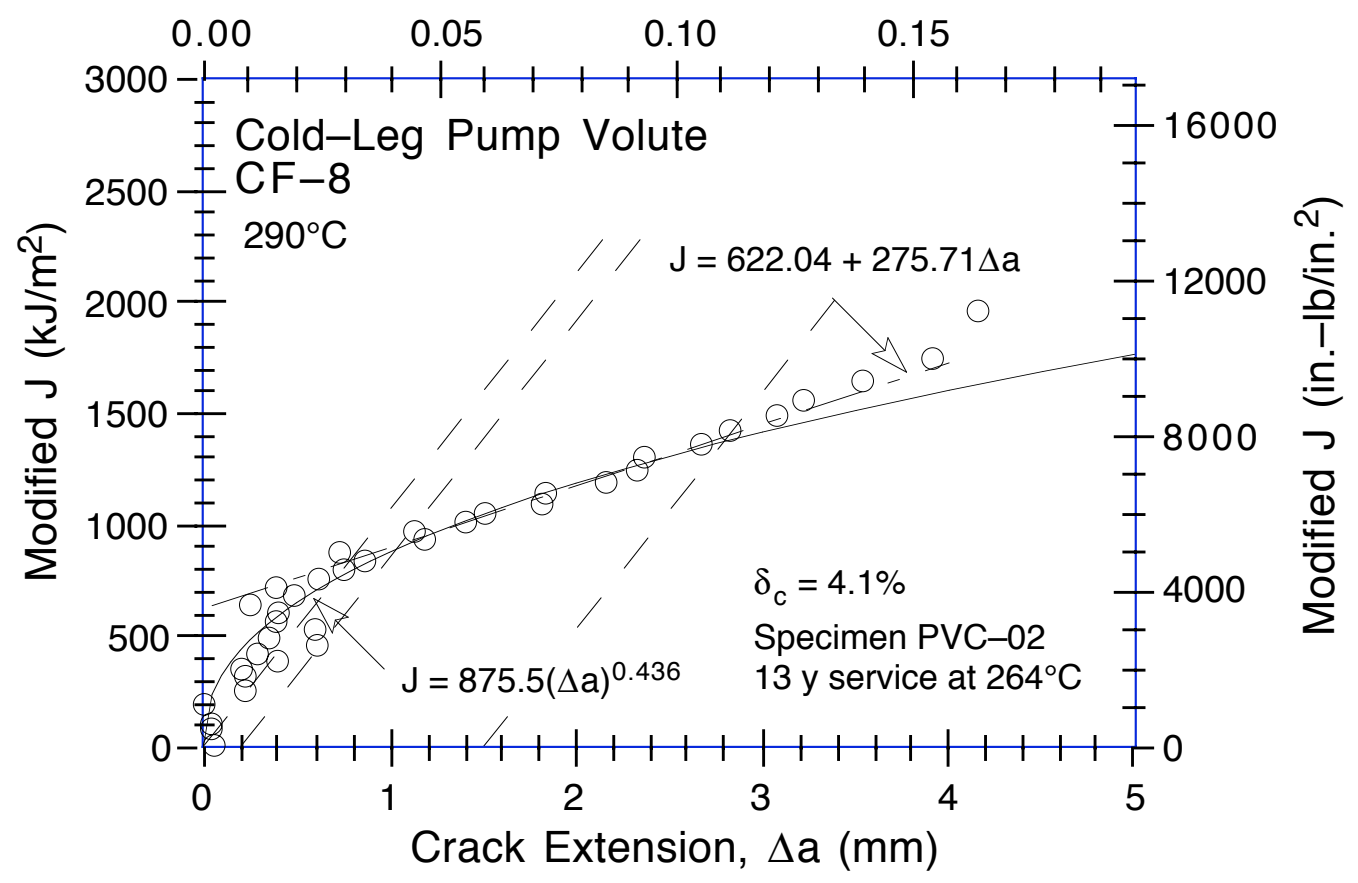

Figure C-46. Modified J-R Curve at $290^{\circ} \mathrm{C}$ for the cold-leg pump volute PV after $13 \mathrm{y}$ of service at $264^{\circ} \mathrm{C}$ 
Table C-47. Test data for specimen PVO-02

\begin{tabular}{|c|c|c|c|c|c|}
\hline $\begin{array}{l}\text { Test Nun } \\
\text { Material } \\
\text { Aging Te } \\
\text { Spec. Th } \\
\text { Spec. Wi }\end{array}$ & $\begin{array}{l}\text { ber } \\
\text { ype } \\
\text { np } \\
\text { kness } \\
\text { th }\end{array}$ & $\begin{array}{l}\mathrm{mm} \\
\mathrm{mm}\end{array}$ & $\begin{array}{l}\text { Test } \\
\text { Heat } \\
\text { Aging } \\
\text { Net T } \\
\text { Flow }\end{array}$ & & $\begin{array}{l}0 \mathrm{~h} \\
7 \mathrm{~mm} \\
0 \mathrm{MPa}\end{array}$ \\
\hline $\begin{array}{c}\text { Unload } \\
\text { Number }\end{array}$ & $\begin{array}{c}J_{d} \\
\left(k J / m^{2}\right)\end{array}$ & $\begin{array}{c}J_{m} \\
\left(k J / m^{2}\right)\end{array}$ & $\begin{array}{c}\Delta \mathrm{a} \\
(\mathrm{mm})\end{array}$ & $\begin{array}{l}\text { Load } \\
(\mathrm{kN})\end{array}$ & $\begin{array}{c}\text { Deflection } \\
(\mathrm{m} \mathrm{m})\end{array}$ \\
\hline 1 & 9.65 & 9.65 & -0.0211 & 11.793 & 0.254 \\
\hline 2 & 26.63 & 26.61 & -0.0263 & 14.058 & 0.506 \\
\hline 3 & 49.80 & 50.05 & 0.0754 & 15.516 & 0.807 \\
\hline 4 & 75.02 & 74.46 & -0.1237 & 16.533 & 1.107 \\
\hline 5 & 101.31 & 101.80 & 0.0618 & 17.441 & 1.407 \\
\hline 6 & 133.83 & 133.67 & -0.0241 & 18.200 & 1.757 \\
\hline 7 & 167.14 & 168.30 & 0.1129 & 18.885 & 2.108 \\
\hline 8 & 201.82 & 203.33 & 0.1436 & 19.569 & 2.459 \\
\hline 9 & 237.09 & 239.73 & 0.2240 & 20.118 & 2.808 \\
\hline 10 & 268.38 & 271.71 & 0.2670 & 20.538 & 3.108 \\
\hline 11 & 303.26 & 310.80 & 0.4992 & 20.967 & 3.460 \\
\hline 12 & 339.54 & 344.02 & 0.3486 & 21.230 & 3.769 \\
\hline 13 & 373.63 & 383.53 & 0.5879 & 21.499 & 4.105 \\
\hline 14 & 408.35 & 417.04 & 0.5393 & 21.673 & 4.406 \\
\hline 15 & 444.46 & 458.99 & 0.7536 & 21.928 & 4.757 \\
\hline 16 & 484.28 & 499.75 & 0.7850 & 22.139 & 5.108 \\
\hline 17 & 518.33 & 542.67 & 1.0605 & 22.287 & 5.457 \\
\hline 18 & 556.68 & 585.12 & 1.1780 & 22.261 & 5.813 \\
\hline 19 & 597.37 & 630.46 & 1.3015 & 22.382 & 6.183 \\
\hline 20 & 629.19 & 671.05 & 1.5208 & 22.287 & 6.509 \\
\hline 21 & 664.65 & 706.61 & 1.5230 & 22.054 & 6.806 \\
\hline 22 & 687.68 & 751.58 & 2.0140 & 21.948 & 7.155 \\
\hline 23 & 725.25 & 792.97 & 2.0947 & 21.881 & 7.505 \\
\hline 24 & 757.67 & 844.59 & $\begin{array}{l}2.4766 \\
\end{array}$ & 21.721 & 7.908 \\
\hline 25 & 797.34 & 893.47 & 2.6493 & 21.394 & 8.308 \\
\hline 26 & 830.09 & 943.99 & 2.9652 & 21.281 & 8.706 \\
\hline 27 & 886.92 & 1005.91 & 3.0492 & 21.230 & 9.207 \\
\hline 28 & 925.48 & 1070.79 & $\begin{array}{l}3.4585 \\
3.455\end{array}$ & 20.766 & 9.707 \\
\hline 29 & 955.32 & 1133.33 & 3.9406 & 20.072 & 10.207 \\
\hline 30 & 994.01 & 1193.79 & 4.2443 & 19.421 & 10.707 \\
\hline 31 & 1021.46 & 1255.40 & $\begin{array}{l}4.6979 \\
\text {. }\end{array}$ & 18.855 & 11.208 \\
\hline 32 & 1066.99 & 1326.34 & 5.0153 & 18.014 & 11.807 \\
\hline 33 & 1087.20 & 1398.25 & 5.6300 & 17.358 & 12.411 \\
\hline 34 & 1098.20 & 1465.26 & 6.2669 & 16.209 & 13.006 \\
\hline $\begin{array}{l}04 \\
35\end{array}$ & 1131.54 & 1530.84 & $\begin{array}{l}0.6157 \\
6.615\end{array}$ & 15.680 & 13.606 \\
\hline 36 & 1160.38 & 1610.16 & 7.1327 & 14.998 & 14.307 \\
\hline 37 & 1172.75 & 1686.67 & 7.7587 & 14.220 & 15.007 \\
\hline
\end{tabular}


Table C-48. Deformation JIC and J-R curve results for specimen PVO-02

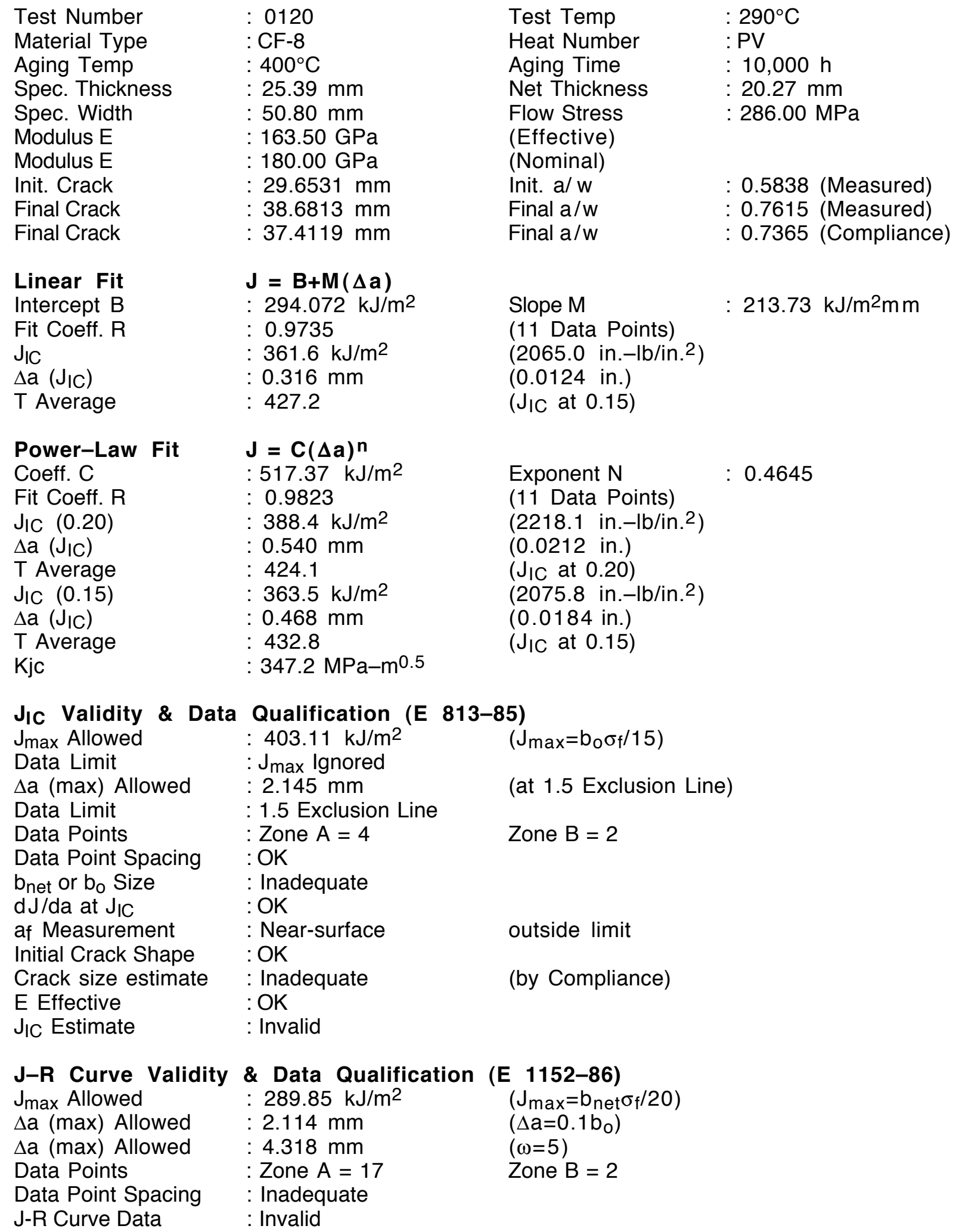


Table C-49. Modified J/C and J-R curve results for specimen PVO-02

\begin{tabular}{|c|c|c|c|}
\hline $\begin{array}{l}\text { Linear Fit } \\
\text { Intercept B } \\
\text { Fit Coeff. R } \\
\mathrm{J}_{\mathrm{IC}} \\
\Delta \mathrm{a}\left(\mathrm{J}_{\mathrm{IC}}\right) \\
\mathrm{T} \text { Average }\end{array}$ & $\begin{array}{l}\mathbf{J}=\mathbf{B}+\mathbf{M}(\Delta \mathbf{a}) \\
: 250.572 \mathrm{~kJ} / \mathrm{m}^{2} \\
: 0.9732 \\
: 328.0 \mathrm{~kJ} / \mathrm{m}^{2} \\
: 0.287 \mathrm{~mm} \\
: 540.0\end{array}$ & $\begin{array}{l}\text { Slope M } \\
(12 \text { Data Points) } \\
\left(1873.2 \text { in.-lb/in. }{ }^{2}\right) \\
(0.0113 \text { in. }) \\
\left(J_{I C} \text { at } 0.15\right)\end{array}$ & $: 270.16 \mathrm{~kJ} / \mathrm{m}^{2} \mathrm{~mm}$ \\
\hline 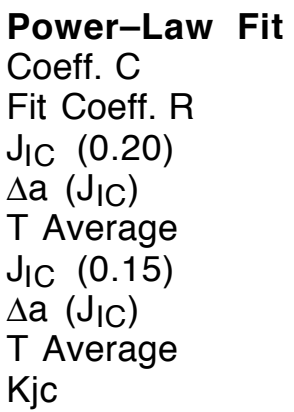 & $\begin{array}{l}\mathbf{J}=\mathbf{C}(\Delta \mathbf{a})^{\mathbf{n}} \\
: 532.11 \mathrm{~kJ} / \mathrm{m}^{2} \\
: 0.9759 \\
: 368.3 \mathrm{~kJ} / \mathrm{m}^{2} \\
: 0.522 \mathrm{~mm} \\
: 538.1 \\
: 336.0 \mathrm{~kJ} / \mathrm{m}^{2} \\
: 0.444 \mathrm{~mm} \\
: 547.6 \\
: 370.2 \mathrm{MPa}-\mathrm{m}^{0.5}\end{array}$ & $\begin{array}{l}\text { Exponent } \mathrm{N} \\
(12 \text { Data Points) } \\
\left(2103.2 \text { in.-lb/in. }{ }^{2}\right) \\
(0.0205 \text { in.) } \\
\left(\mathrm{J}_{\mathrm{IC}} \text { at } 0.20\right) \\
\left(1918.4 \text { in.-lb/in. }{ }^{2}\right) \\
(0.0175 \text { in.) } \\
\left(\mathrm{J}_{\mathrm{IC}} \text { at } 0.15\right)\end{array}$ & 0.5658 \\
\hline
\end{tabular}

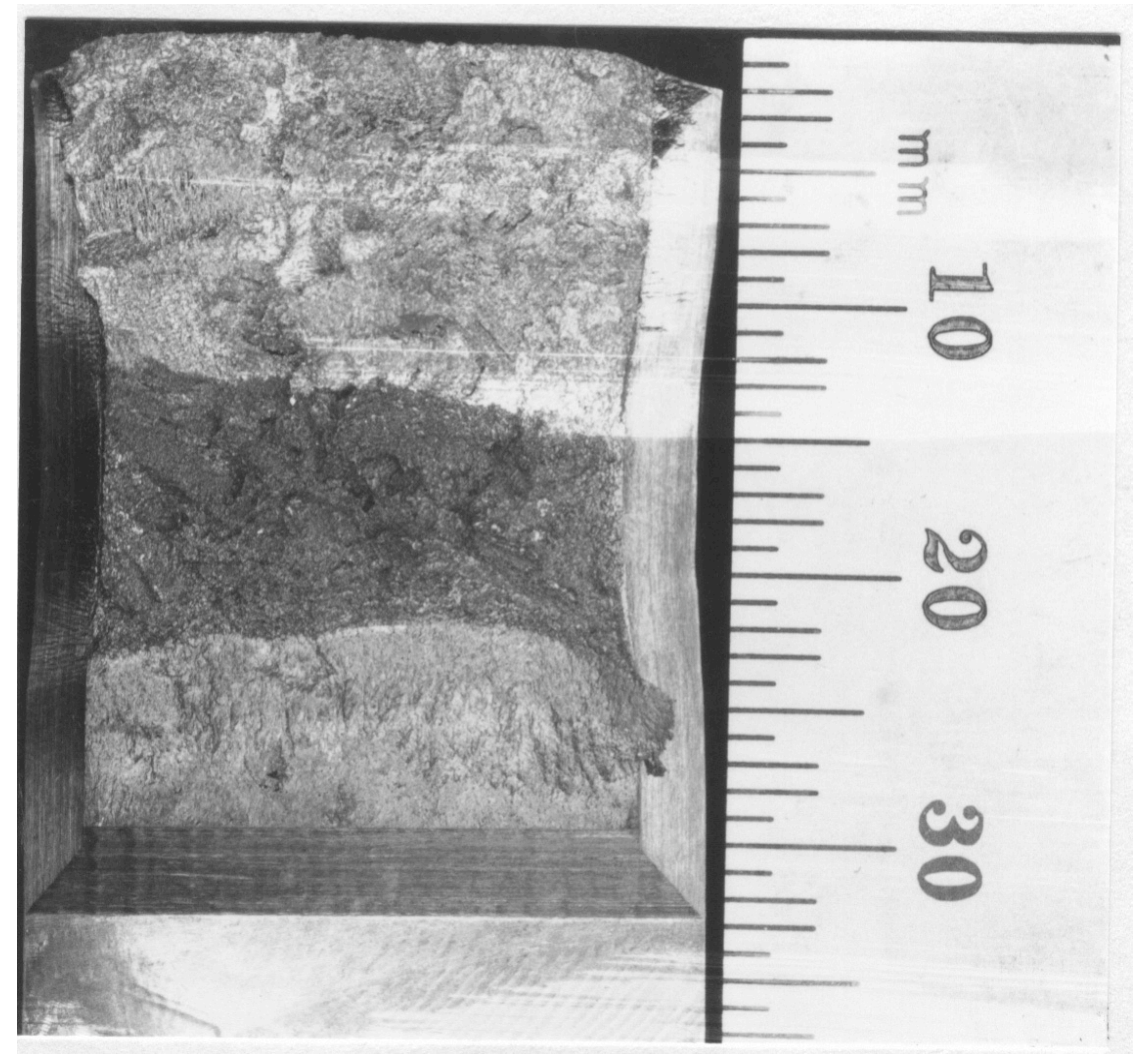

Figure C-47. Fracture surface of service-aged material PV from the pump volute aged further for $10,000 \mathrm{~h}$ at $400^{\circ} \mathrm{C}$ and tested at $290^{\circ} \mathrm{C}$ 


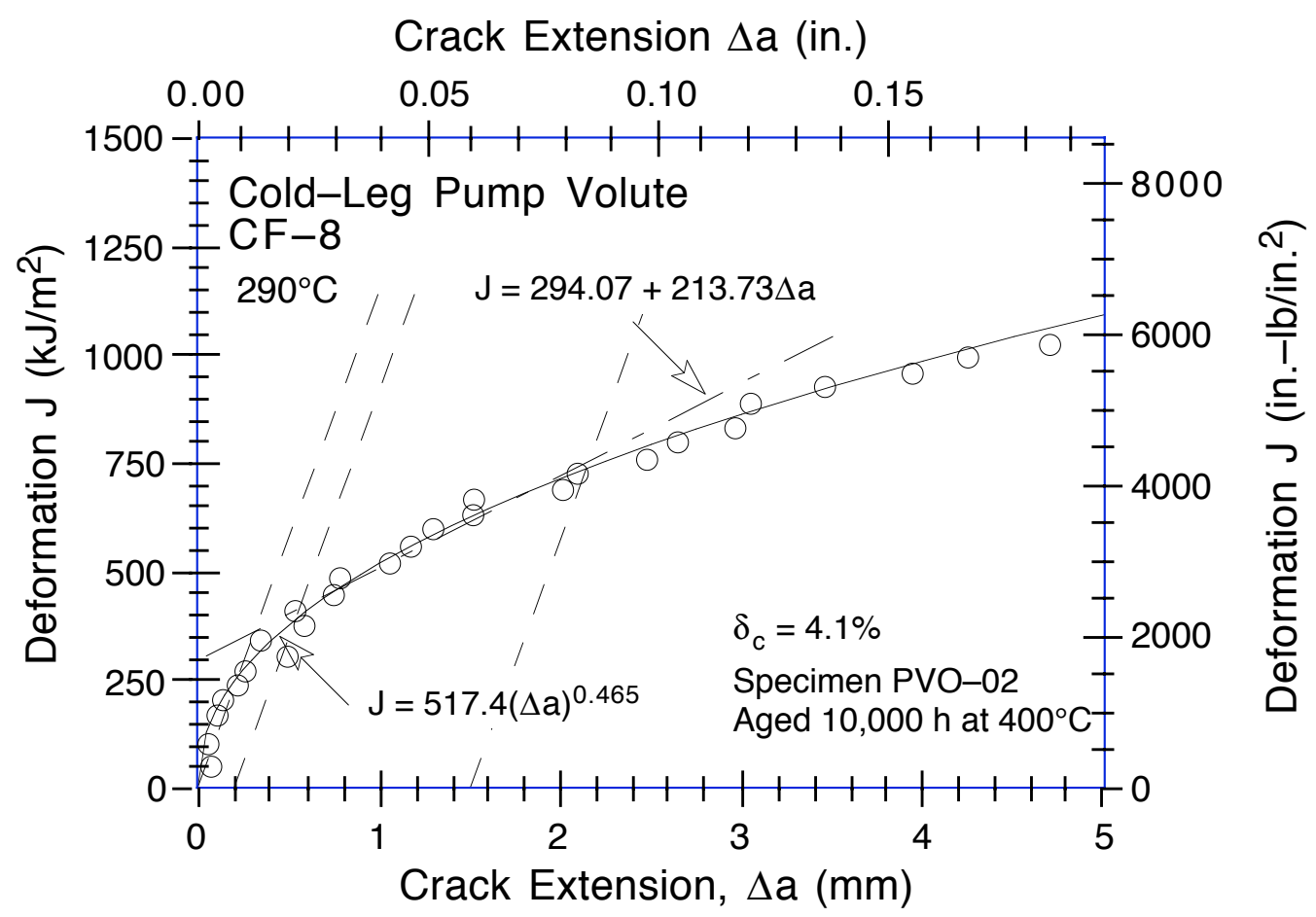

Figure C-48. Deformation $J-R$ Curve at $290^{\circ} \mathrm{C}$ of service-aged material PV from the pump volute aged further for $10,000 \mathrm{~h}$ at $400^{\circ} \mathrm{C}$

Crack Extension $\Delta \mathrm{a}$ (in.)

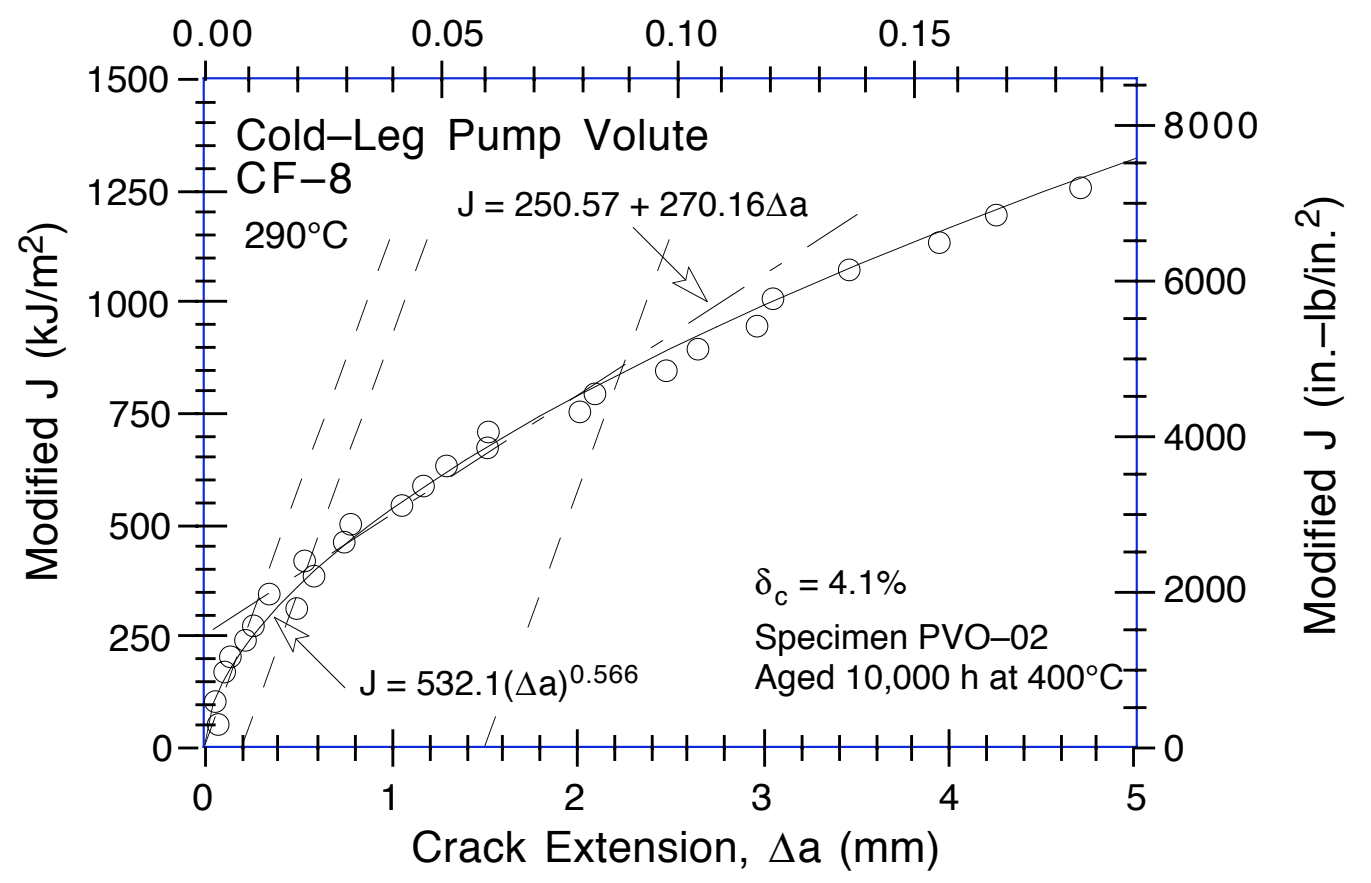

Figure C-49. Modified $J-R$ Curve at $290^{\circ} \mathrm{C}$ of service-aged material PV from the pump volute aged further for $10,000 \mathrm{~h}$ at $400^{\circ} \mathrm{C}$ 
Table C-50. Test data for specimen VRI-01

\begin{tabular}{|c|c|c|c|c|c|}
\hline \multicolumn{2}{|c|}{$\begin{array}{l}\text { Test Number } \\
\text { Material Type } \\
\text { Aging Temp. } \\
\text { Spec. Thickness } \\
\text { Spec. Width }\end{array}$} & $\begin{array}{l}: 0082 \\
: \mathrm{CF}-8 \\
: 25^{\circ} \mathrm{C} \\
: 25.40 \mathrm{~mm} \\
: 50.81 \mathrm{~mm}\end{array}$ & \multicolumn{2}{|c|}{$\begin{array}{l}\text { Test Temp. } \\
\text { Heat Number } \\
\text { Aging Time } \\
\text { Net Thickness } \\
\text { Flow Stress }\end{array}$} & $\begin{array}{l}: 25^{\circ} \mathrm{C} \\
: \mathrm{VR} \\
: 0 \mathrm{~h} \\
: 20.25 \mathrm{~mm} \\
: 405.00 \mathrm{MPa}\end{array}$ \\
\hline $\begin{array}{c}\text { Unload } \\
\text { Number }\end{array}$ & $\begin{array}{c}J_{d} \\
\left(k J / m^{2}\right)\end{array}$ & $\begin{array}{c}J_{m} \\
\left(k J / m^{2}\right)\end{array}$ & $\begin{array}{c}\Delta \mathrm{a} \\
(\mathrm{m} \mathrm{m})\end{array}$ & $\begin{array}{l}\text { Load } \\
(\mathrm{kN})\end{array}$ & $\begin{array}{c}\text { Deflection } \\
(\mathrm{m} \mathrm{m})\end{array}$ \\
\hline 1 & 19.34 & 19.27 & -0.1614 & 22.264 & 0.302 \\
\hline 2 & 58.57 & 58.95 & 0.0300 & 27.614 & 0.606 \\
\hline 3 & 101.65 & 102.00 & 0.0232 & 29.814 & 0.909 \\
\hline 4 & 147.89 & 148.17 & 0.0143 & 31.023 & 1.209 \\
\hline 5 & 195.51 & 196.95 & 0.1266 & 32.047 & 1.510 \\
\hline 6 & 245.20 & 246.76 & 0.1358 & 33.050 & 1.815 \\
\hline 7 & 295.06 & 297.52 & 0.1912 & 33.482 & 2.113 \\
\hline 8 & 345.61 & 349.13 & 0.2466 & 34.298 & 2.411 \\
\hline 9 & 396.55 & 402.32 & 0.3482 & 34.958 & 2.711 \\
\hline 10 & 450.70 & 455.00 & 0.2905 & 35.236 & 3.010 \\
\hline 11 & 502.46 & 512.32 & 0.4838 & 35.824 & 3.315 \\
\hline 12 & 558.59 & 566.22 & 0.4143 & 36.405 & 3.616 \\
\hline 13 & 611.42 & 624.64 & 0.5722 & 36.713 & 3.918 \\
\hline 14 & 666.75 & 679.11 & 0.5499 & 36.914 & 4.211 \\
\hline 15 & 719.31 & 737.93 & 0.6985 & 37.203 & 4.511 \\
\hline 16 & 783.71 & 805.12 & 0.7588 & 37.403 & 4.861 \\
\hline 17 & 844.04 & 874.43 & 0.9380 & 37.655 & 5.209 \\
\hline 18 & 908.45 & 943.89 & 1.0309 & 37.929 & 5.562 \\
\hline 19 & 969.29 & 1014.34 & 1.1956 & 38.031 & 5.911 \\
\hline 20 & 1031.37 & 1084.51 & 1.3249 & 37.927 & 6.260 \\
\hline 21 & 1092.61 & 1156.11 & 1.4802 & 37.829 & 6.612 \\
\hline 22 & 1148.04 & 1227.94 & 1.7118 & 38.055 & 6.962 \\
\hline 23 & 1209.98 & 1298.12 & 1.8217 & 37.915 & 7.310 \\
\hline 24 & 1262.02 & 1370.89 & 2.0836 & 37.444 & 7.659 \\
\hline 25 & 1323.68 & 1441.14 & 2.1865 & 37.159 & 8.009 \\
\hline 26 & 1376.92 & 1513.83 & 2.4082 & 36.709 & 8.359 \\
\hline 27 & 1425.81 & 1585.97 & 2.6616 & 36.588 & 8.711 \\
\hline 28 & 1484.79 & 1656.33 & 2.7800 & 36.324 & 9.061 \\
\hline 29 & 1535.56 & 1730.44 & 3.0124 & 35.787 & 9.417 \\
\hline 30 & 1591.70 & 1813.86 & 3.2712 & 34.856 & 9.826 \\
\hline 31 & 1638.26 & 1891.19 & 3.5514 & 34.379 & 10.210 \\
\hline 32 & 1703.85 & 1991.91 & 3.8548 & 33.798 & 10.711 \\
\hline 33 & 1773.59 & 2091.68 & 4.1012 & 33.567 & 11.210 \\
\hline 34 & 1862.18 & 2214.43 & 4.3649 & 33.290 & 11.815 \\
\hline 35 & 1944.39 & 2336.18 & 4.6532 & 32.851 & 12.412 \\
\hline 36 & 2013.03 & 2457.60 & 5.0183 & 31.687 & 13.012 \\
\hline 37 & 2097.03 & 2596.29 & 5.3753 & 31.043 & 13.710 \\
\hline 38 & 2171.49 & 2735.73 & 5.7766 & 30.129 & 14.412 \\
\hline 39 & 2255.15 & 2889.73 & 6.1849 & 27.685 & 15.212 \\
\hline
\end{tabular}


Table C-51. Deformation J/C and J-R curve results for specimen VRI-01

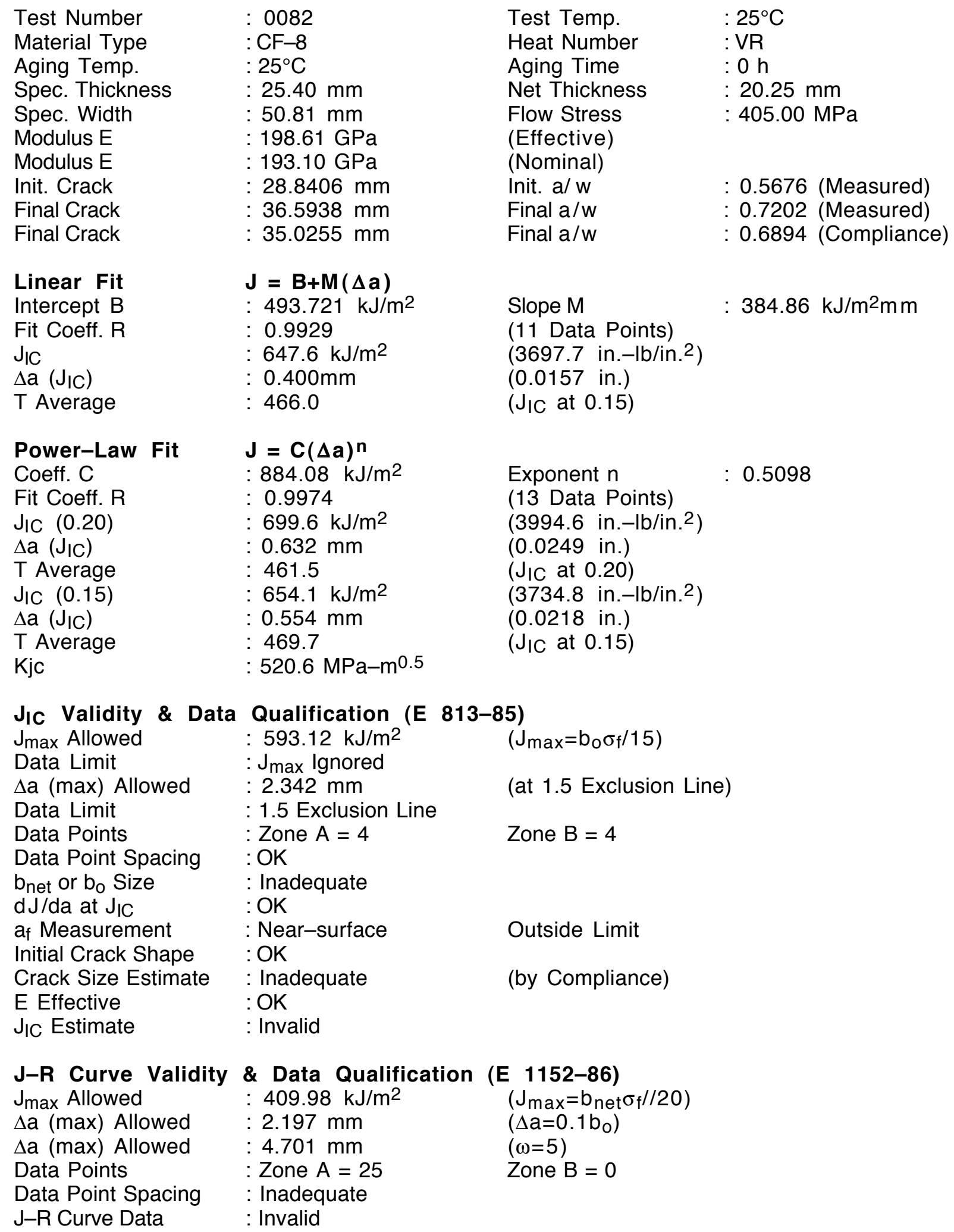


Table C-52. Modified J/C and J-R curve results for specimen VRI-01

\begin{tabular}{|c|c|c|c|}
\hline $\begin{array}{l}\text { Linear Fit } \\
\text { Intercept B } \\
\text { Fit Coeff. R } \\
J_{I C} \\
\Delta \text { a }\left(\mathrm{J}_{\mathrm{IC}}\right) \\
T \text { Average }\end{array}$ & $\begin{array}{l}\mathbf{J}=\mathbf{B}+\mathbf{M}(\Delta \mathbf{a}) \\
: 472.274 \mathrm{~kJ} / \mathrm{m}^{2} \\
: 0.9961 \\
: 649.6 \mathrm{~kJ} / \mathrm{m}^{2} \\
: 0.401 \mathrm{~mm} \\
: 535.5\end{array}$ & $\begin{array}{l}\text { Slope M } \\
\text { (12 Data Points) } \\
\left(3709.5 \text { in.-lb/in. }{ }^{2}\right) \\
(0.0158 \text { in.) } \\
\left(J_{I C} \text { at } 0.15\right)\end{array}$ & $: 442.26 \mathrm{~kJ} / \mathrm{m}^{2} \mathrm{~mm}$ \\
\hline $\begin{array}{l}\text { Power-Law Fit } \\
\text { Coeff. C } \\
\text { Fit Coeff. R } \\
\mathrm{J}_{\mathrm{IC}}(0.20) \\
\Delta \mathrm{a}\left(\mathrm{J}_{\mathrm{IC}}\right) \\
\text { T Average } \\
\mathrm{J}_{\mathrm{IC}}(0.15) \\
\Delta \mathrm{a}\left(\mathrm{J}_{\mathrm{IC}}\right) \\
\text { T Average } \\
\text { Kjc }\end{array}$ & $\begin{array}{l}\mathbf{J}=\mathbf{C}(\Delta \mathbf{a})^{\mathbf{n}} \\
: 919.57 \mathrm{~kJ} / \mathrm{m}^{2} \\
: 0.9986 \\
: 716.3 \mathrm{~kJ} / \mathrm{m}^{2} \\
: 0.642 \mathrm{~mm} \\
: 532.6 \\
: 662.3 \mathrm{~kJ} / \mathrm{m}^{2} \\
: 0.559 \mathrm{~mm} \\
: 541.2 \\
: 549.5 \mathrm{MPa}-\mathrm{m}^{0.5}\end{array}$ & $\begin{array}{l}\text { Exponent } n \\
(12 \text { Data Points) } \\
\left(4090.3 \text { in. }-\mathrm{lb} / \mathrm{in} .{ }^{2}\right) \\
(0.0253 \text { in.) } \\
\left(\mathrm{J}_{\mathrm{IC}} \text { at } 0.20\right) \\
\left(3781.9 \text { in. }-\mathrm{lb} / \mathrm{in}^{2}{ }^{2}\right) \\
(0.0220 \text { in.) } \\
\left(\mathrm{J}_{\mathrm{IC}} \text { at } 0.15\right)\end{array}$ & 0.5640 \\
\hline
\end{tabular}

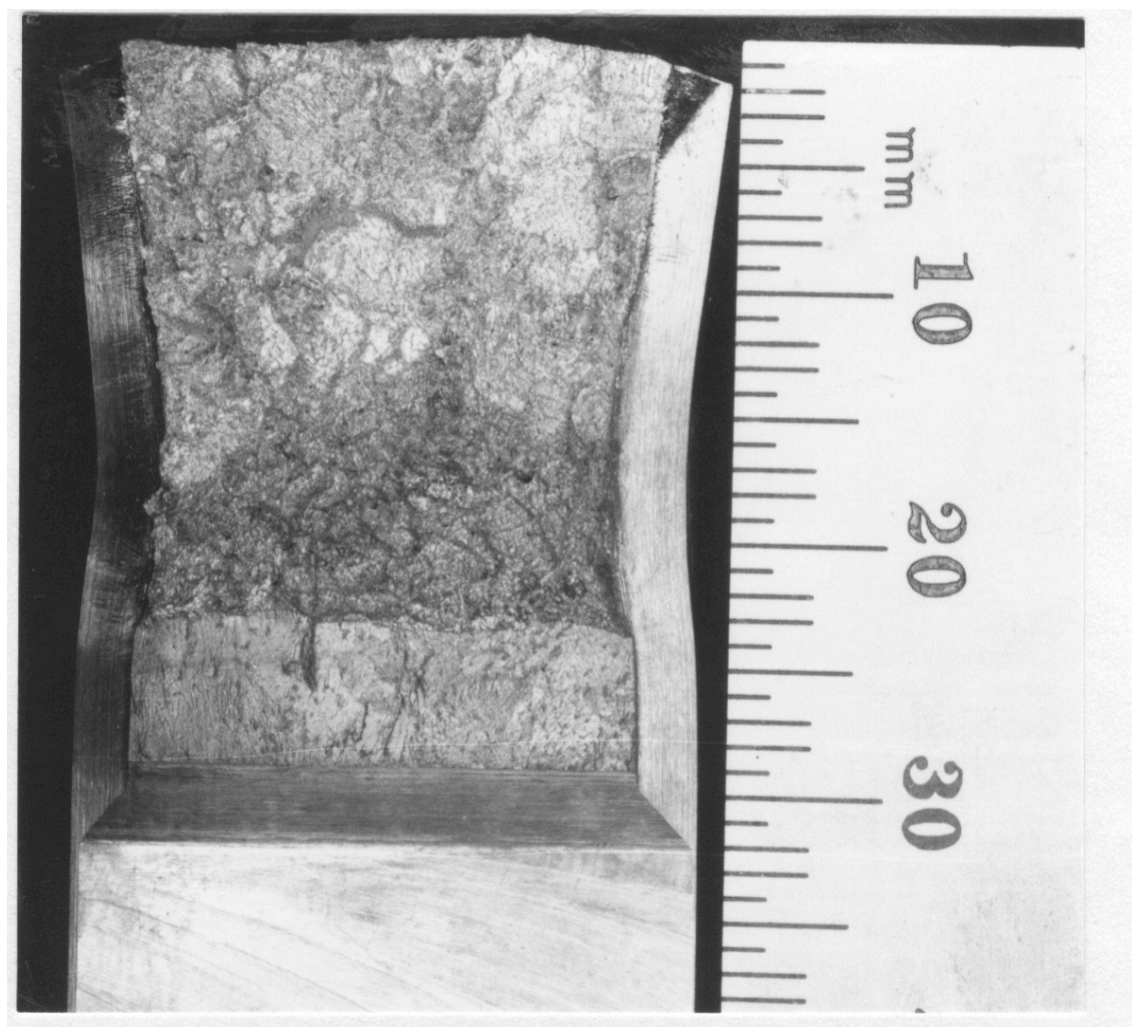

Figure C-50. Fracture surface of the unaged spare pump volute VR tested at room temperature 


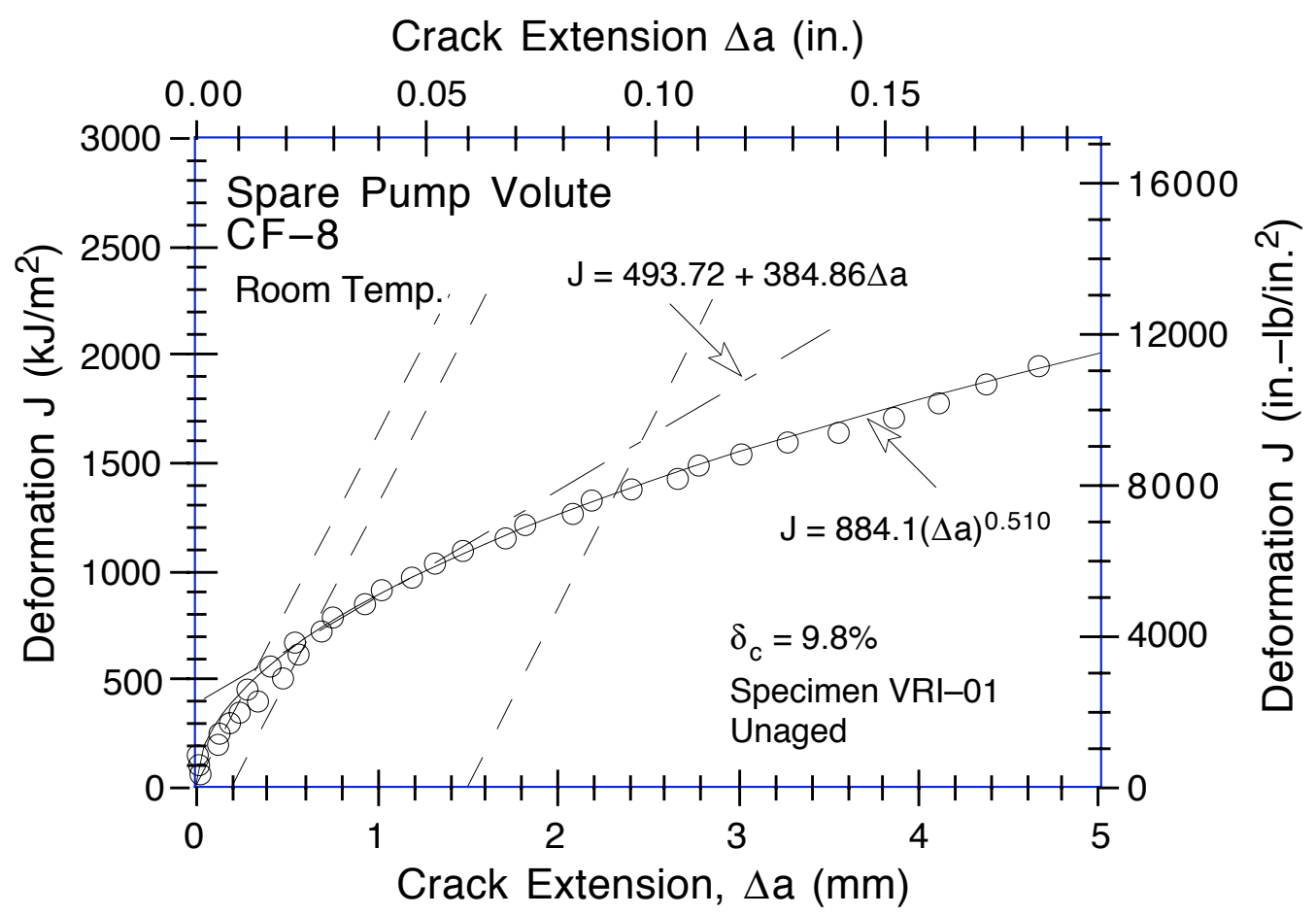

Figure $C-51$. Deformation $J-R$ Curve at room temperature for unaged spare pump volute $V R$

Crack Extension $\Delta$ a (in.)

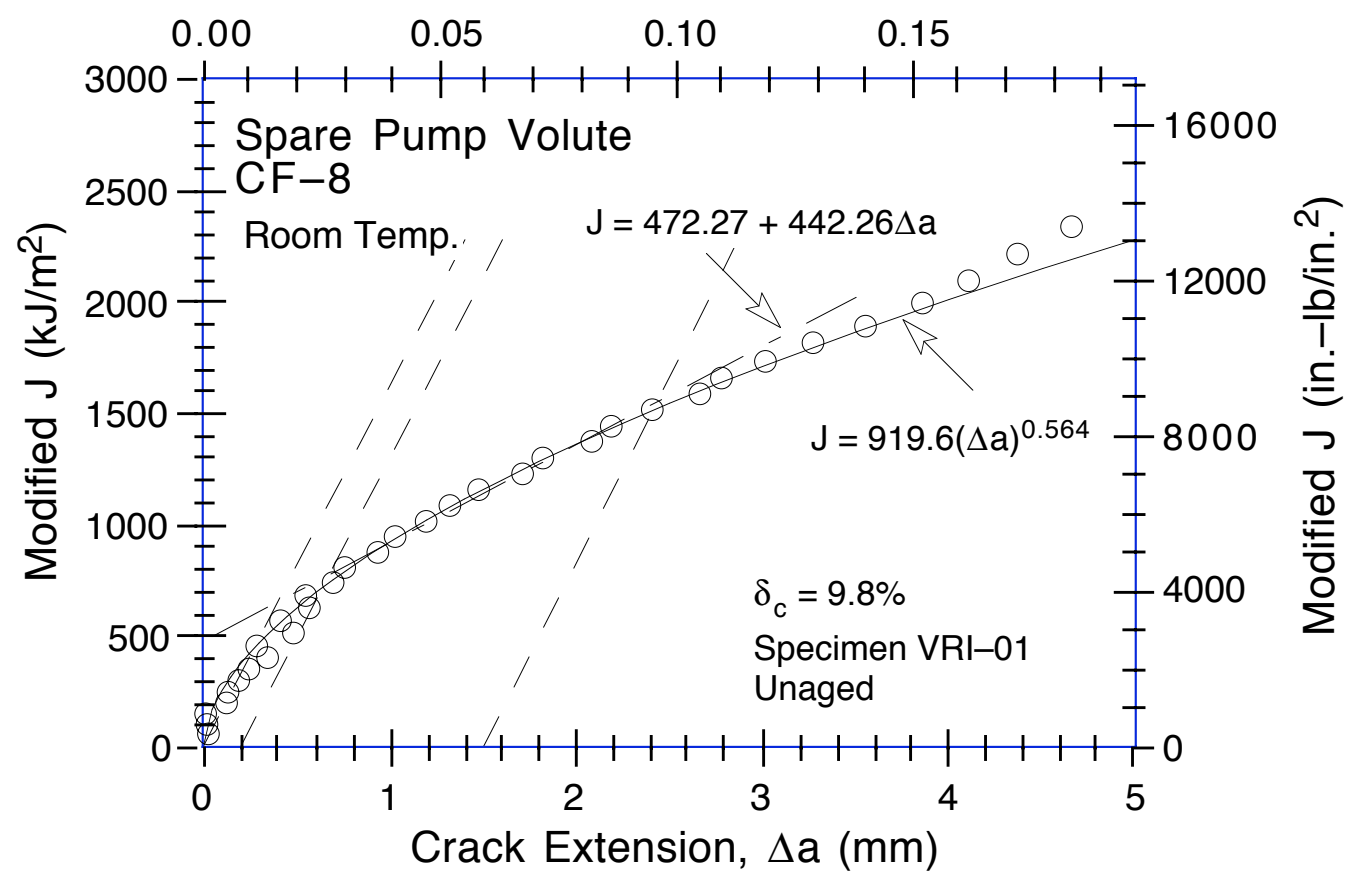

Figure $C-52$. Modified $J-R$ Curve at room temperature for unaged spare pump volute $V R$ 
Table C-53. Test data for specimen VRO-02

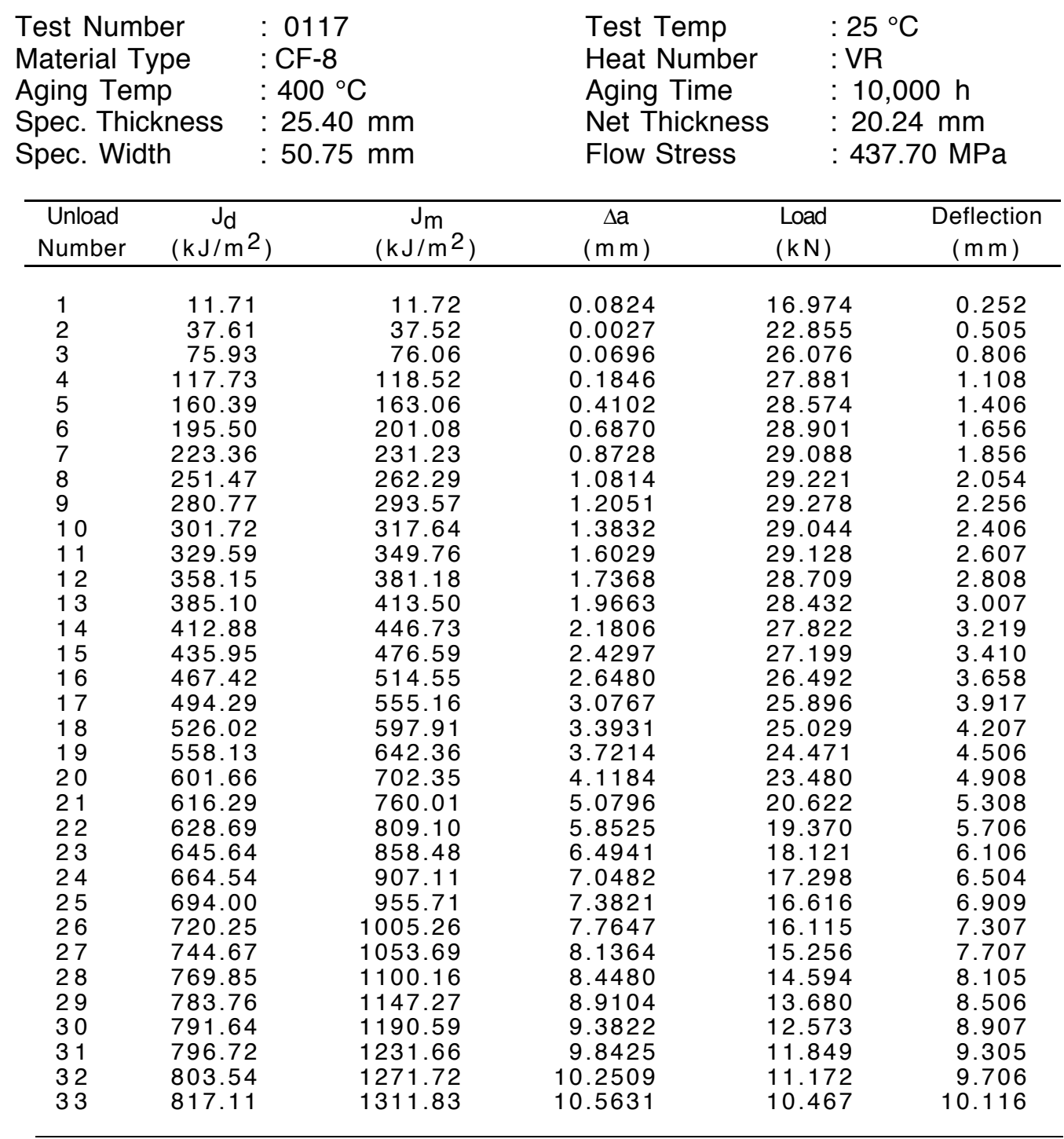


Table C-54. Deformation J/C and J-R curve results for specimen VRO-02

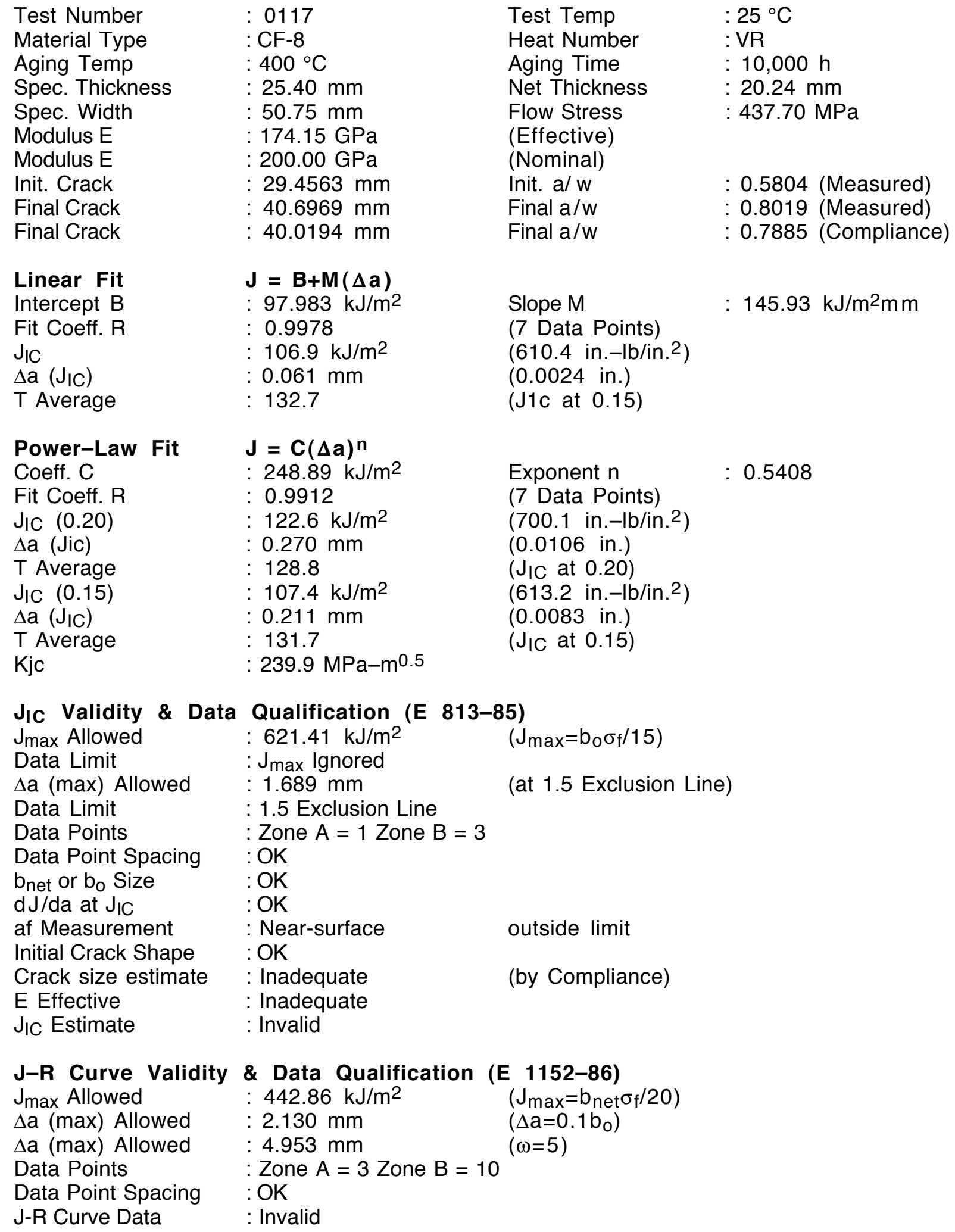


Table C-55. Modified J/C and J-R curve results for specimen VRO-02

\begin{tabular}{|c|c|c|c|}
\hline $\begin{array}{l}\text { Linear Fit } \\
\text { Intercept B } \\
\text { Fit Coeff. R } \\
\mathrm{J}_{\mathrm{IC}} \\
\Delta \mathrm{a}\left(\mathrm{J}_{\mathrm{IC}}\right) \\
\mathrm{T} \text { Average }\end{array}$ & $\begin{array}{l}\mathbf{J}=\mathbf{B}+\mathbf{M}(\Delta \mathbf{a}) \\
: 93.678 \mathrm{~kJ} / \mathrm{m}^{2} \\
: 0.9981 \\
: 103.1 \mathrm{~kJ} / \mathrm{m}^{2} \\
: 0.059 \mathrm{~mm} \\
: 146.0\end{array}$ & $\begin{array}{l}\text { Slope M } \\
\text { ( } 7 \text { Data Points) } \\
\left(588.9 \text { in.-lb/in. }{ }^{2}\right) \\
(0.0023 \text { in.) } \\
\left(J_{\text {IC } \text { at } 0.15)}\right.\end{array}$ & $: 160.56 \mathrm{~kJ} / \mathrm{m}^{2} \mathrm{~mm}$ \\
\hline 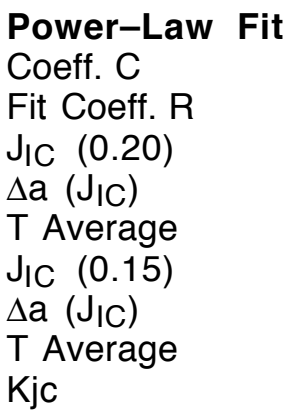 & $\begin{array}{l}\mathbf{J}=\mathbf{C}(\Delta \mathbf{a})^{\mathbf{n}} \\
: 259.31 \mathrm{~kJ} / \mathrm{m}^{2} \\
: 0.9912 \\
: 122.8 \mathrm{~kJ} / \mathrm{m}^{2} \\
: 0.270 \mathrm{~mm} \\
: 140.8 \\
: 106.6 \mathrm{~kJ} / \mathrm{m}^{2} \\
: 0.211 \mathrm{~mm} \\
: 143.7 \\
: 247.3 \mathrm{MPa}-\mathrm{m}^{0.5}\end{array}$ & $\begin{array}{l}\text { Exponent } \mathrm{n} \\
(7 \text { Data Points) } \\
\left(701.0 \text { in.-lb/in. }{ }^{2}\right) \\
(0.0106 \text { in. }) \\
\left(\mathrm{J}_{\mid C} \text { at } 0.20\right) \\
\left(608.5 \text { in. }-\mathrm{lb} / \mathrm{in}^{2}\right) \\
(0.0083 \text { in. }) \\
\left(\mathrm{J}_{\mathrm{IC}} \text { at } 0.15\right)\end{array}$ & 0.5713 \\
\hline
\end{tabular}

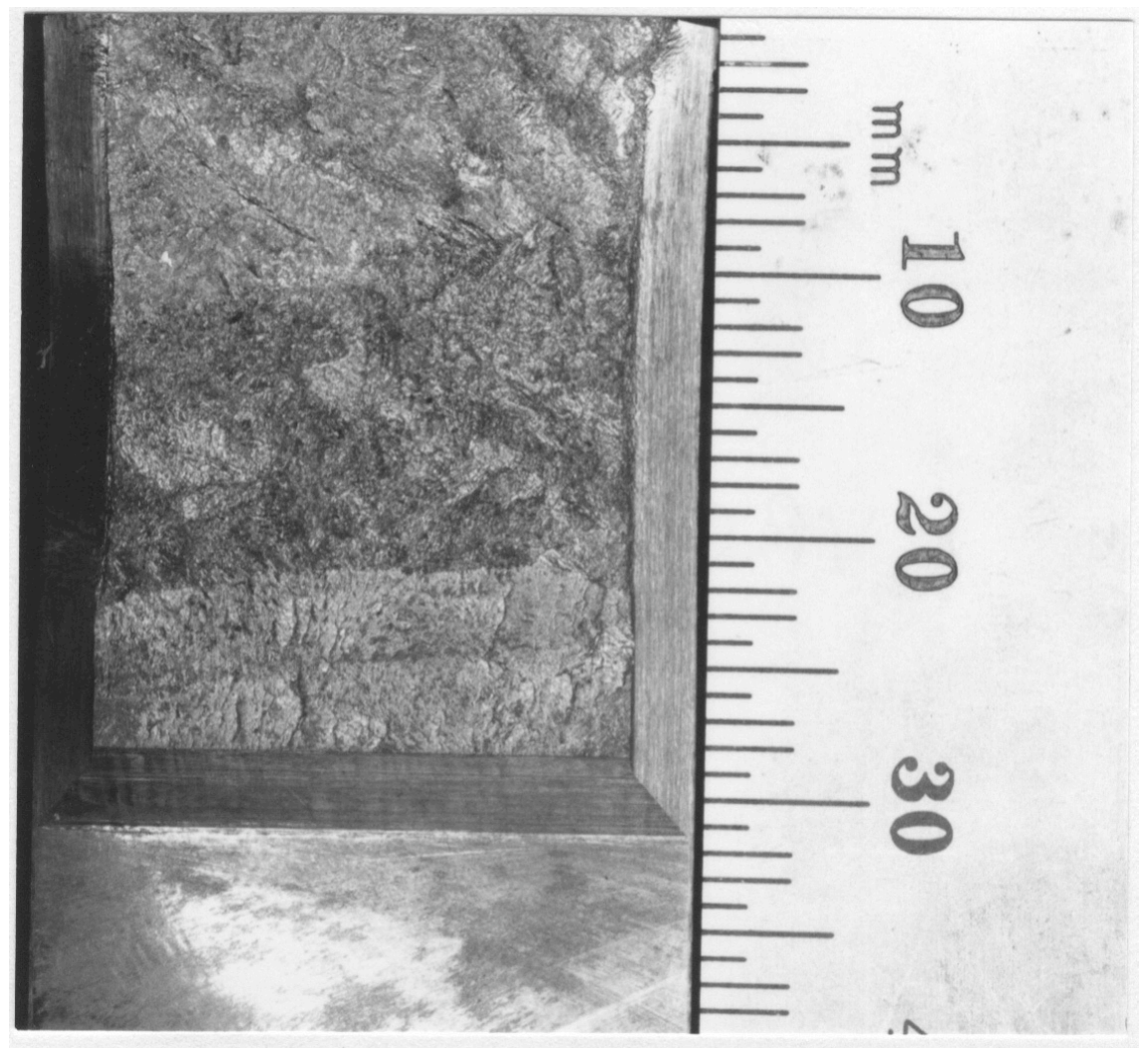

Figure C-53. Fracture surface of material from the spare pump volute $V R$ aged $10,000 \mathrm{~h}$ at $400^{\circ} \mathrm{C}$ and tested at room temperature 


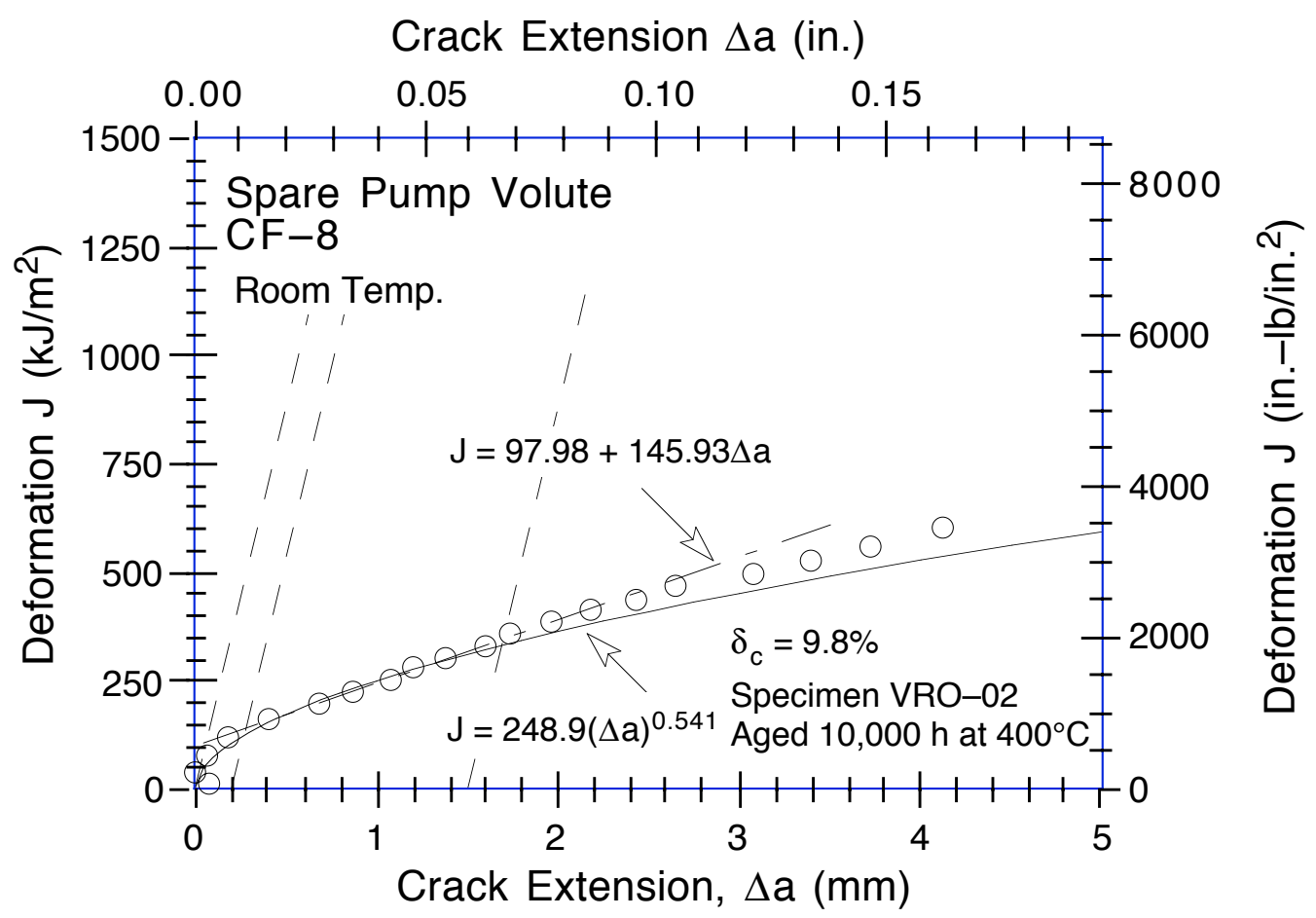

Figure $C-54$. Deformation $J-R$ Curve at room temperature for material from the spare pump volute VR aged $10,000 \mathrm{~h}$ at $400^{\circ} \mathrm{C}$

Crack Extension $\Delta$ a (in.)

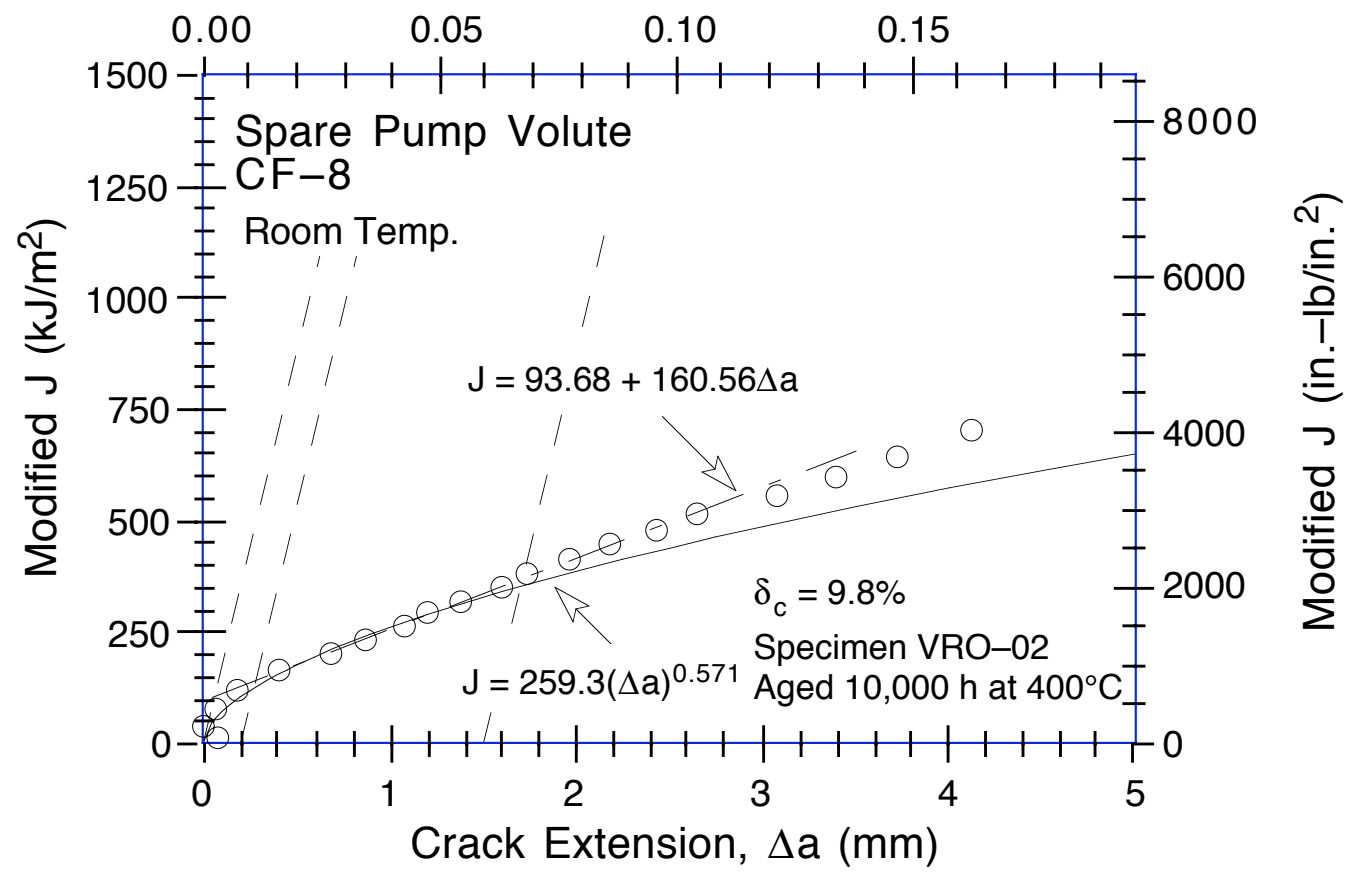

Figure $C-55$. Modified $\mathrm{J}-R$ Curve at room temperature for material from the spare pump volute $V R$ aged $10,000 \mathrm{~h}$ at $400^{\circ} \mathrm{C}$ 
Table C-56. Test data for specimen VRO-01

\begin{tabular}{|c|c|c|c|c|c|}
\hline $\begin{array}{l}\text { Test Nun } \\
\text { Material } \\
\text { Aging Te } \\
\text { Spec. Th } \\
\text { Spec. Wi }\end{array}$ & $\begin{array}{l}\text { ber } \\
\text { ype } \\
\text { np. } \\
\text { kness } \\
\text { th }\end{array}$ & $\begin{array}{l}\mathrm{mm} \\
\mathrm{mm}\end{array}$ & $\begin{array}{l}\text { Test } \\
\text { Heat } \\
\text { Aging } \\
\text { Net T } \\
\text { Flow }\end{array}$ & & $\begin{array}{c}\mathrm{mm} \\
3 \mathrm{MPa}\end{array}$ \\
\hline $\begin{array}{c}\text { Unload } \\
\text { Number }\end{array}$ & $\begin{array}{c}J_{d} \\
\left(k J / m^{2}\right)\end{array}$ & $\begin{array}{c}J_{m} \\
\left(k J / m^{2}\right)\end{array}$ & $\begin{array}{c}\Delta \mathrm{a} \\
(\mathrm{mm})\end{array}$ & $\begin{array}{l}\text { Load } \\
(\mathrm{kN})\end{array}$ & $\begin{array}{c}\text { Deflection } \\
(\mathrm{m} \mathrm{m})\end{array}$ \\
\hline 1 & 15.91 & 15.94 & 0.0553 & 15547 & 0.318 \\
\hline 2 & 40.17 & 39.93 & -0.0958 & 18.143 & 0.607 \\
\hline 3 & 68.59 & 69.31 & 0.1872 & 19.553 & 0.910 \\
\hline 4 & 98.60 & 97.45 & -0.1773 & 20.520 & 1.208 \\
\hline 5 & 129.73 & 130.19 & 0.0539 & 21.327 & 1.509 \\
\hline 6 & 162.87 & 161.37 & -0.1671 & 22.037 & 1.810 \\
\hline 7 & 193.74 & 196.05 & 0.1871 & 22.609 & 2.108 \\
\hline 8 & 226.69 & 229.86 & 0.2548 & 23.250 & 2.410 \\
\hline 9 & 261.18 & 265.22 & 0.3138 & 23.786 & 2.709 \\
\hline 10 & 296.36 & 301.80 & 0.3974 & 24.242 & 3.011 \\
\hline 11 & 331.10 & 338.77 & 0.5145 & 24.632 & 3.309 \\
\hline 12 & 366.68 & 376.62 & 0.6214 & 24.952 & 3.611 \\
\hline 13 & 399.35 & 415.54 & 0.8895 & 25.091 & 3.910 \\
\hline 14 & 438.27 & 453.20 & 0.8404 & 25.289 & 4.212 \\
\hline 15 & 472.16 & 493.45 & 1.0679 & 25.427 & 4.510 \\
\hline 16 & 508.57 & 533.16 & 1.1768 & 25.644 & 4.815 \\
\hline 17 & 540.05 & 573.63 & 1.4538 & 25.769 & 5.111 \\
\hline 18 & 580.24 & 612.70 & 1.4219 & 25.784 & 5.411 \\
\hline 19 & 605.19 & 656.27 & 1.9235 & 25.686 & 5.714 \\
\hline 20 & 638.55 & 695.00 & 2.0597 & 25.552 & 6.011 \\
\hline 21 & 666.08 & 737.24 & 2.4119 & 25.304 & 6.310 \\
\hline 22 & 705.14 & 777.44 & 2.4377 & 25.372 & 6.613 \\
\hline 23 & 733.88 & 820.84 & 2.7522 & 25.347 & 6.912 \\
\hline 24 & 778.46 & $\begin{array}{l}861.36 \\
861.36\end{array}$ & 2.6700 & 25.205 & 7.217 \\
\hline 25 & 811.71 & 919.46 & 3.1426 & 24.670 & 7.611 \\
\hline 26 & 841.39 & 972.55 & 3.5635 & 23.580 & 8.003 \\
\hline 27 & 868.95 & 1027.34 & 4.0288 & 23.107 & 8.410 \\
\hline 28 & 913.08 & 1093.48 & 4.3809 & 22.634 & 8.905 \\
\hline 29 & 967.92 & 1175.21 & 4.7788 & 21.890 & 9.508 \\
\hline 30 & 1011.39 & 1255.24 & 5.2839 & 20.890 & 10.110 \\
\hline 31 & 1046.09 & 1332.69 & 5.8400 & 20.106 & 10.711 \\
\hline 32 & 1088.61 & 1408.41 & 6.2462 & 19.386 & 11.311 \\
\hline 33 & 1119.11 & 1484.76 & 6.7773 & 18.701 & 11.910 \\
\hline 34 & 1165.44 & 1558.48 & 7.0769 & 18.096 & 12.509 \\
\hline $\begin{array}{l}04 \\
35\end{array}$ & 1178.81 & 1634.68 & 7.7320 & 16.843 & 13.122 \\
\hline 36 & 1192.05 & 1703.24 & 8.2852 & 16.274 & 13.711 \\
\hline 37 & 1237.26 & 1772.48 & 8.5133 & 15.821 & 14.310 \\
\hline 38 & 1268.42 & 1857.21 & 8.9943 & 14.816 & 15.012 \\
\hline
\end{tabular}


Table C-57. Deformation J/C and J-R curve results for specimen VRO-01

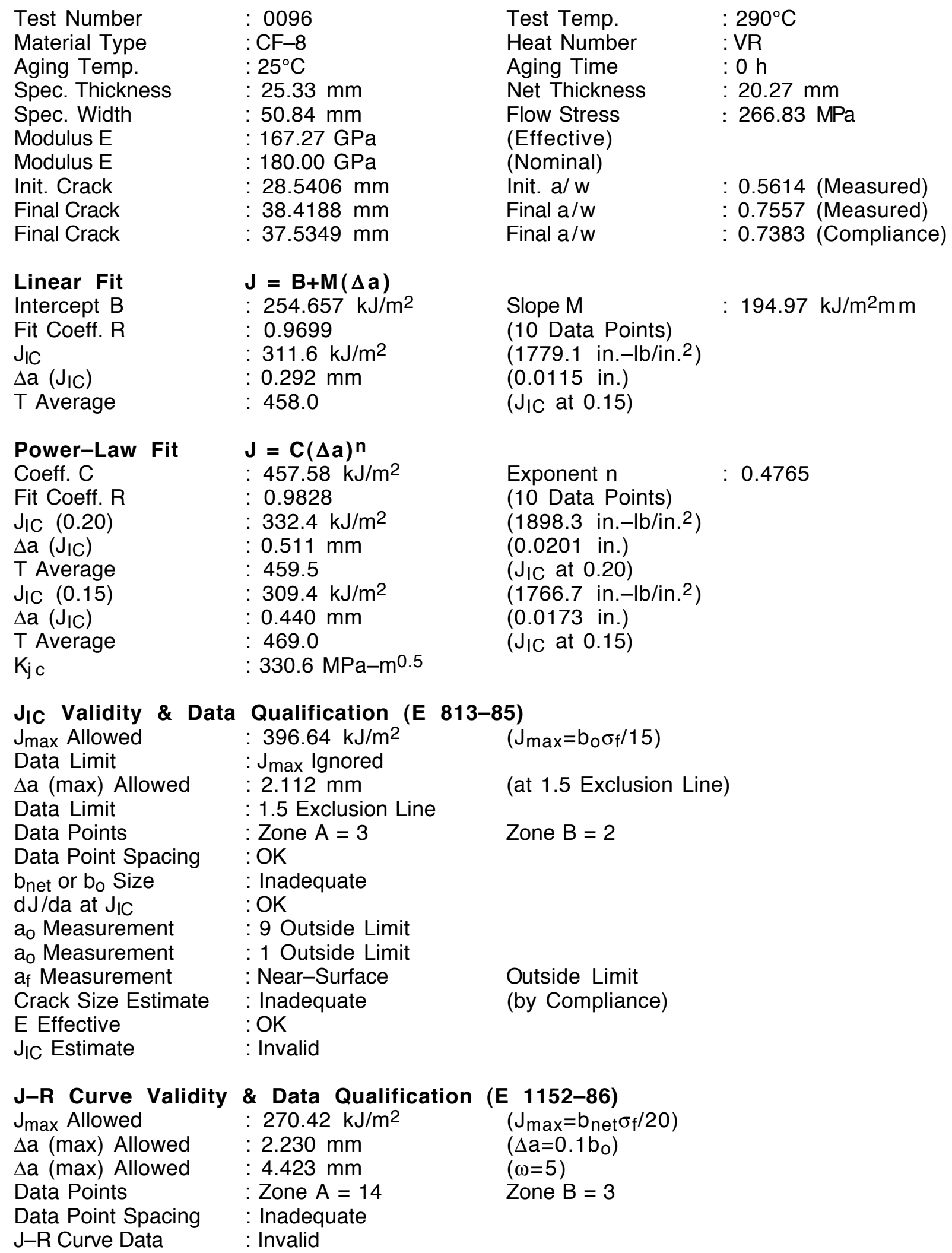


Table C-58. Modified J/C and J-R curve results for specimen VRO-01

\begin{tabular}{|c|c|c|c|}
\hline $\begin{array}{l}\text { Linear Fit } \\
\text { Intercept B } \\
\text { Fit Coeff. R } \\
\mathrm{J}_{\mathrm{IC}} \\
\Delta \mathrm{a}\left(\mathrm{J}_{\mathrm{IC}}\right) \\
\mathrm{T} \text { Average }\end{array}$ & $\begin{array}{l}\mathbf{J}=\mathbf{B}+\mathbf{M}(\Delta \mathbf{a}) \\
: 243.338 \mathrm{~kJ} / \mathrm{m}^{2} \\
: 0.9793 \\
: 309.0 \mathrm{~kJ} / \mathrm{m}^{2} \\
: 0.290 \mathrm{~mm} \\
: 532.9\end{array}$ & $\begin{array}{l}\text { Slope } M \\
\text { (10 Data Points) } \\
\left(1764.5 \text { in.-lb/in. }{ }^{2}\right) \\
(0.0114 \text { in. }) \\
\left(J_{I C} \text { at } 0.15\right)\end{array}$ & : 226.83 \\
\hline 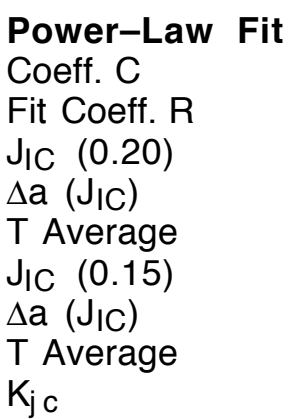 & 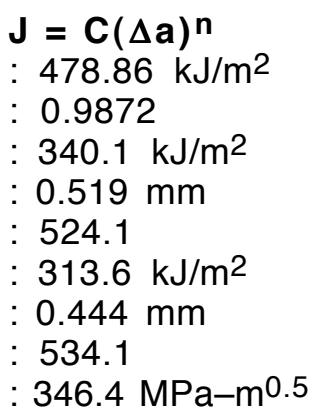 & $\begin{array}{l}\text { Exponent } n \\
(10 \text { Data Points) } \\
\left(1942.2 \text { in.-lb/in. }{ }^{2}\right) \\
(0.0204 \text { in.) } \\
\left(\mathrm{J}_{\mathrm{IC}} \text { at } 0.20\right) \\
\left(1790.7 \text { in. }-\mathrm{lb} / \text { in. }^{2}\right) \\
(0.0175 \text { in.) } \\
\left(\mathrm{J}_{\mathrm{IC}} \text { at } 0.15\right)\end{array}$ & 0.5211 \\
\hline
\end{tabular}

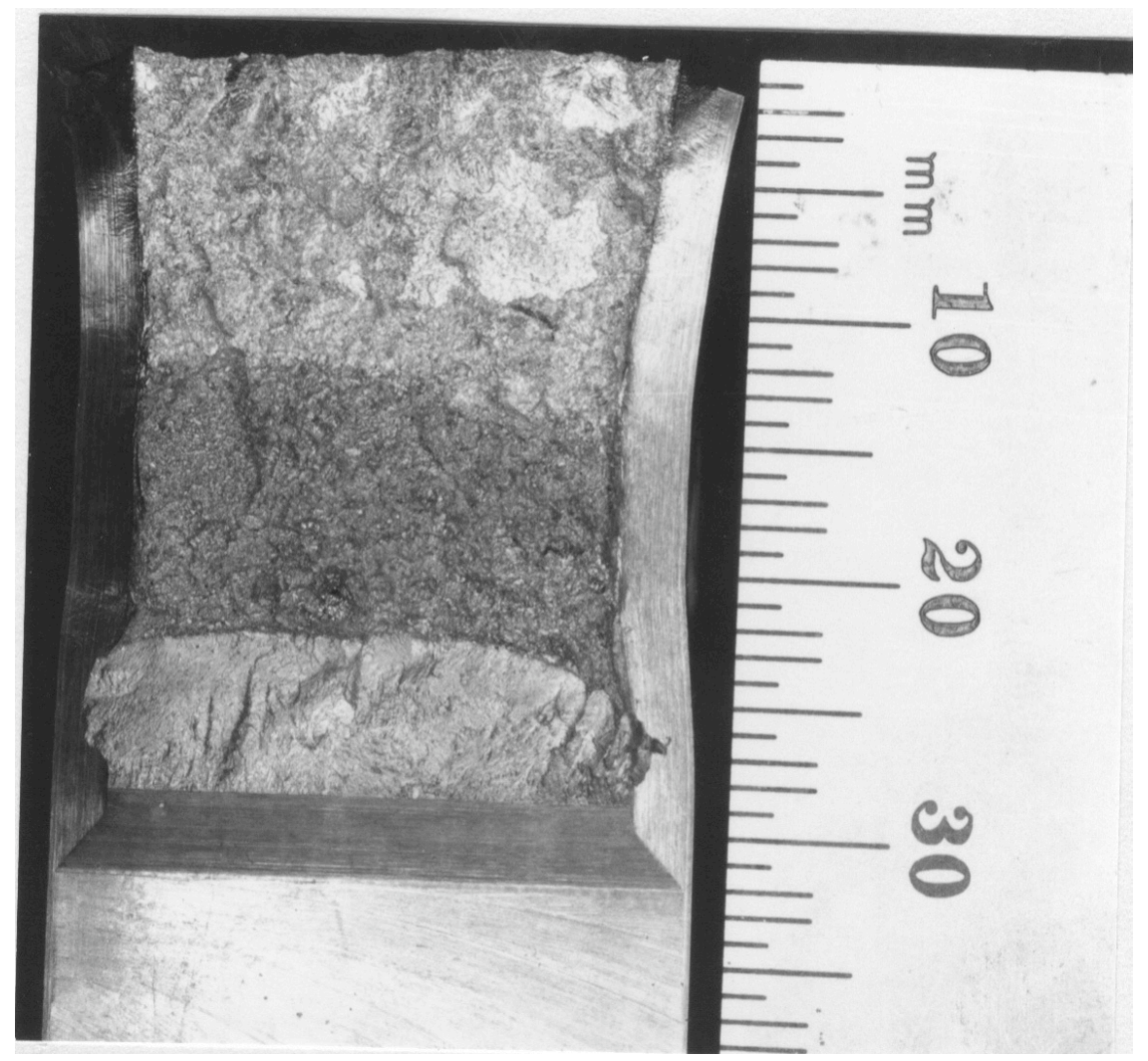

Figure C-56. Fracture surface of the unaged spare pump volute $V R$ tested at $290^{\circ} \mathrm{C}$ 


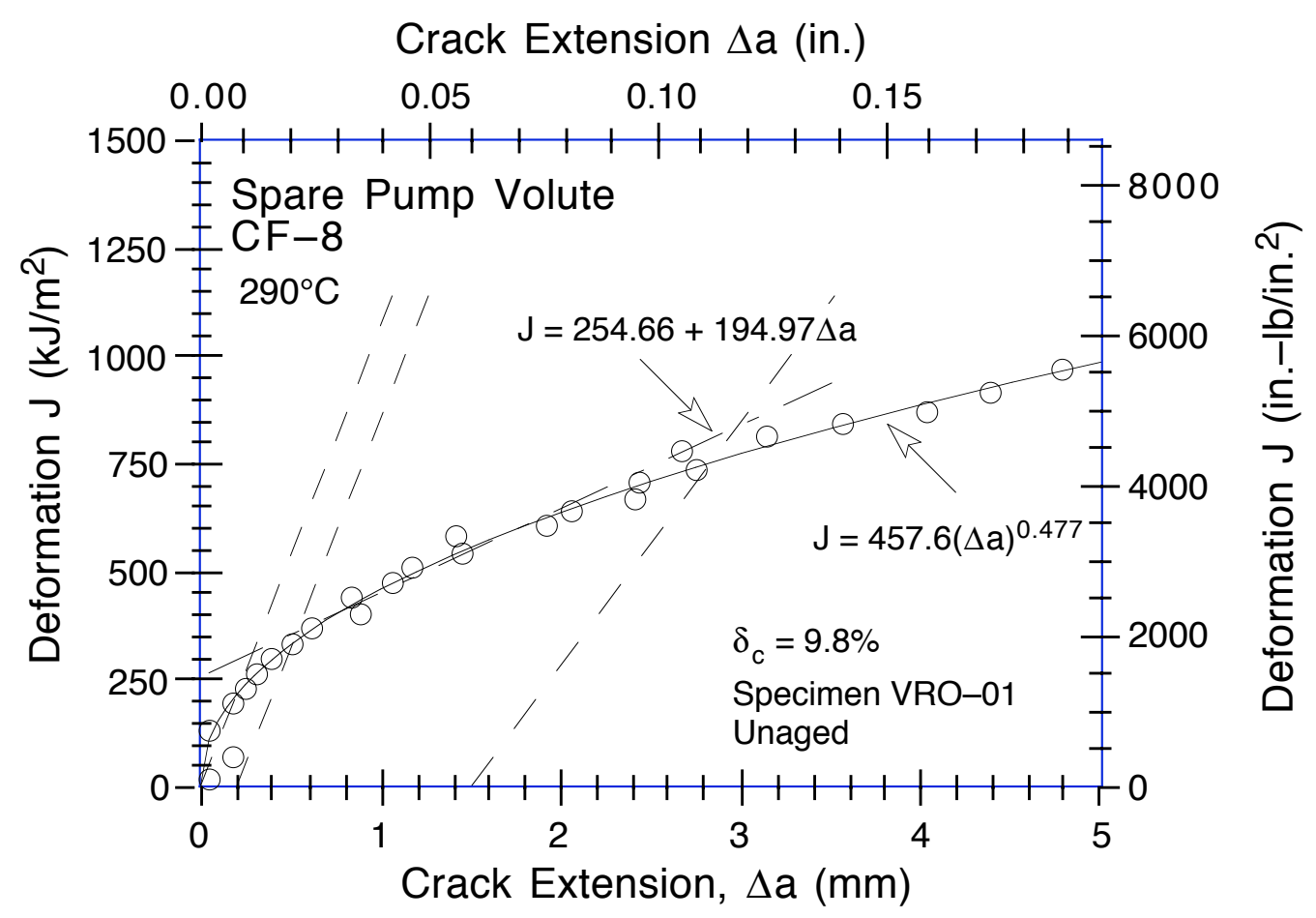

Figure C-57. Deformation $J-R$ Curve at $290^{\circ} \mathrm{C}$ for unaged spare pump volute VR

\section{Crack Extension $\Delta a($ in.)}

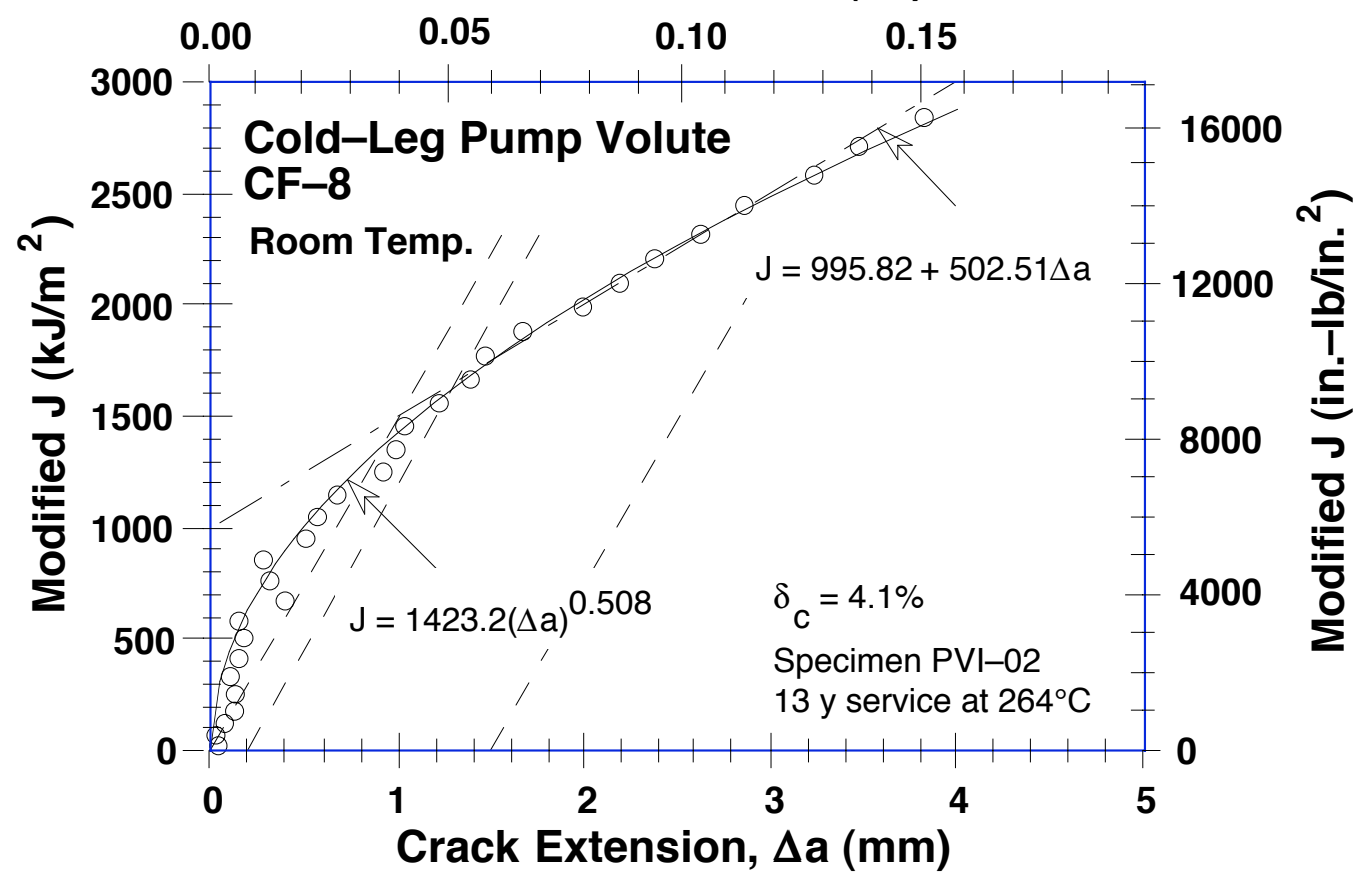

Figure C-58. Modified J-R Curve at $290^{\circ} \mathrm{C}$ for unaged spare pump volute $V R$ 
Table C-59. Test data for specimen VRI-02

\begin{tabular}{|c|c|c|c|c|c|}
\hline $\begin{array}{l}\text { Test Nun } \\
\text { Material } \\
\text { Aging Te } \\
\text { Spec. Th } \\
\text { Spec. Wi }\end{array}$ & $\begin{array}{l}\text { er } \\
\text { pe } \\
\text { ness } \\
n\end{array}$ & $\mathrm{~mm}$ & $\begin{array}{l}\text { Test } \\
\text { Heat } \\
\text { Aging } \\
\text { Net T } \\
\text { Flow }\end{array}$ & & $\begin{array}{l}0 \mathrm{~h} \\
\mathrm{~mm} \\
0 \mathrm{MPa}\end{array}$ \\
\hline $\begin{array}{c}\text { Unload } \\
\text { Number }\end{array}$ & $\begin{array}{c}J_{d} \\
\left(k J / m^{2}\right)\end{array}$ & $\begin{array}{c}J_{m} \\
\left(k J / m^{2}\right)\end{array}$ & $\begin{array}{c}\Delta \mathrm{a} \\
(\mathrm{mm})\end{array}$ & $\begin{array}{l}\text { Load } \\
(\mathrm{kN})\end{array}$ & $\begin{array}{c}\text { Deflection } \\
(\mathrm{m} \mathrm{m})\end{array}$ \\
\hline 1 & 11.27 & 11.24 & -0.1042 & 15.270 & 0.255 \\
\hline 2 & 42.07 & 42.43 & 0.1060 & 19.718 & 0.605 \\
\hline 3 & 83.39 & 84.12 & 0.1964 & 22.275 & 1.008 \\
\hline 4 & 128.46 & 129.82 & 0.2891 & 23.877 & 1.407 \\
\hline 5 & 176.68 & 178.04 & 0.2892 & 25.022 & 1.806 \\
\hline 6 & 226.20 & 229.51 & 0.4454 & 25.791 & 2.207 \\
\hline 7 & 269.61 & 274.71 & 0.5638 & 26.235 & 2.555 \\
\hline 8 & 308.23 & 322.96 & 1.1097 & 26.463 & 2.905 \\
\hline 9 & 354.48 & 368.06 & 1.0535 & 26.560 & 3.257 \\
\hline 10 & 395.79 & 418.07 & 1.4272 & 26.516 & 3.607 \\
\hline 11 & 435.67 & 465.67 & 1.7243 & 26.010 & 3.958 \\
\hline 12 & 468.49 & 514.77 & 2.2933 & 25.524 & 4.311 \\
\hline 13 & 509.83 & 559.04 & 2.3866 & 24.998 & $\begin{array}{l}4.654 \\
\text {. }\end{array}$ \\
\hline 14 & 537.28 & 608.90 & 3.0450 & 24.085 & 5.009 \\
\hline 15 & 573.52 & 660.29 & 3.4548 & 23.687 & 5.406 \\
\hline 16 & 614.33 & 713.45 & 3.7620 & 23.452 & 5.807 \\
\hline 17 & 644.42 & 767.96 & 4.3276 & 22.947 & 6.205 \\
\hline 18 & 684.87 & 819.78 & 4.5718 & 22.254 & 6.607 \\
\hline 19 & 718.15 & 873.02 & 4.9726 & 21.339 & 7.006 \\
\hline 20 & 741.44 & 925.13 & 5.5188 & 20.523 & 7.409 \\
\hline 21 & 769.53 & 973.63 & 5.8844 & 19.589 & 7.805 \\
\hline 22 & 790.96 & 1023.56 & 6.3686 & 18.622 & 8.209 \\
\hline 23 & 805.95 & 1071.10 & 6.8969 & 17.850 & 8.606 \\
\hline 24 & 815.67 & 1117.20 & 7.4624 & 16.585 & 9.005 \\
\hline 25 & 819.79 & 1160.81 & 8.0527 & 15.335 & 9.405 \\
\hline 26 & 830.33 & 1203.09 & 8.5090 & 14.748 & 9.807 \\
\hline 27 & 843.13 & 1245.59 & 8.9191 & 14.074 & 10.207 \\
\hline 28 & 852.34 & 1287.52 & 9.3540 & 13.460 & 10.606 \\
\hline 29 & 861.93 & 1328.39 & 9.7548 & 12.958 & 11.005 \\
\hline 30 & 888.45 & 1379.39 & 10.0524 & 12.220 & 11.505 \\
\hline 31 & 887.35 & 1429.21 & 10.6458 & 10.897 & 12.008 \\
\hline 32 & 879.58 & 1472.71 & 11.2237 & 10.133 & 12.505 \\
\hline 33 & 874.98 & 1514.85 & 11.7323 & 9.284 & 13.005 \\
\hline 34 & 868.79 & 1555.74 & 12.2275 & 8.555 & 13.505 \\
\hline
\end{tabular}


Table C-60. Deformation J/C and J-R curve results for specimen VRI-02

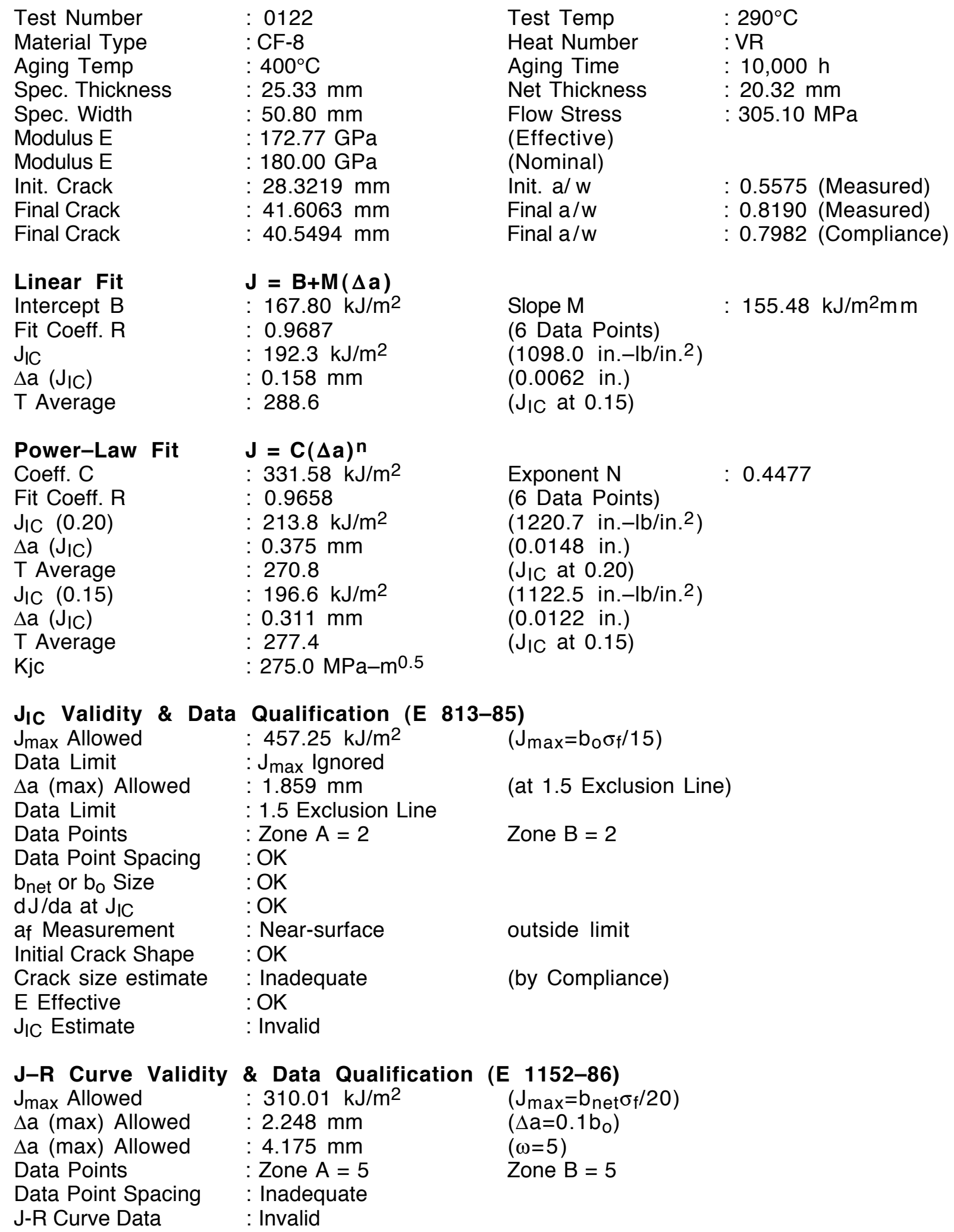


Table C-61. Modified J/C and $J-R$ curve results for specimen VRI-02

\begin{tabular}{|c|c|c|c|}
\hline $\begin{array}{l}\text { Linear Fit } \\
\text { Intercept B } \\
\text { Fit Coeff. R } \\
\mathrm{J}_{\mathrm{IC}} \\
\Delta \mathrm{a}\left(\mathrm{J}_{\mathrm{IC}}\right) \\
\text { T Average }\end{array}$ & $\begin{array}{l}\mathbf{J}=\mathbf{B}+\mathbf{M}(\Delta \mathbf{a}) \\
: 160.956 \mathrm{~kJ} / \mathrm{m}^{2} \\
: 0.9751 \\
: 188.1 \mathrm{~kJ} / \mathrm{m}^{2} \\
: 0.154 \mathrm{~mm} \\
: 326.7\end{array}$ & $\begin{array}{l}\text { Slope } M \\
(6 \text { Data Points) } \\
\left(1074.0 \text { in. }-\mathrm{lb} / \mathrm{in}^{2}\right) \\
(0.0061 \text { in. }) \\
\left(\mathrm{J}_{\mathrm{IC}} \text { at } 0.15\right)\end{array}$ & $: 176.04 \mathrm{~kJ} / \mathrm{m}^{2} \mathrm{~mm}$ \\
\hline $\begin{array}{l}\text { Power-Law Fit } \\
\text { Coeff. C } \\
\text { Fit Coeff. } \mathrm{R} \\
\mathrm{J}_{\mathrm{IC}}(0.20) \\
\Delta \mathrm{a}\left(\mathrm{J}_{\mathrm{IC}}\right) \\
\mathrm{T} \text { Average } \\
\mathrm{J}_{\mathrm{IC}}(0.15) \\
\Delta \mathrm{a}\left(\mathrm{J}_{\mathrm{IC}}\right) \\
\text { T Average } \\
\mathrm{K}_{\mathrm{j} \mathrm{C}}\end{array}$ & $\begin{array}{l}\mathbf{J}=\mathbf{C}(\Delta \mathbf{a})^{\mathbf{n}} \\
: 345.76 \mathrm{~kJ} / \mathrm{m}^{2} \\
: 0.9717 \\
: 215.1 \mathrm{~kJ} / \mathrm{m}^{2} \\
: 0.376 \mathrm{~mm} \\
: 304.5 \\
: 196.0 \mathrm{~kJ} / \mathrm{m}^{2} \\
: 0.311 \mathrm{~mm} \\
: 311.4 \\
: 285.1 \mathrm{MPa}-\mathrm{m}^{0.5}\end{array}$ & $\begin{array}{l}\text { Exponent } \mathrm{N} \\
(6 \text { Data Points) } \\
\left(128.3 \text { in.-lb/in. }{ }^{2}\right) \\
(0.0148 \text { in.) } \\
\left(\mathrm{J}_{\mathrm{IC}} \text { at } 0.20\right) \\
\left(1119.1 \text { in.-lb/in. }{ }^{2}\right) \\
(0.0122 \text { in.) } \\
\left(\mathrm{J}_{\mathrm{IC}} \text { at } 0.15\right)\end{array}$ & $: 0.4855$ \\
\hline
\end{tabular}

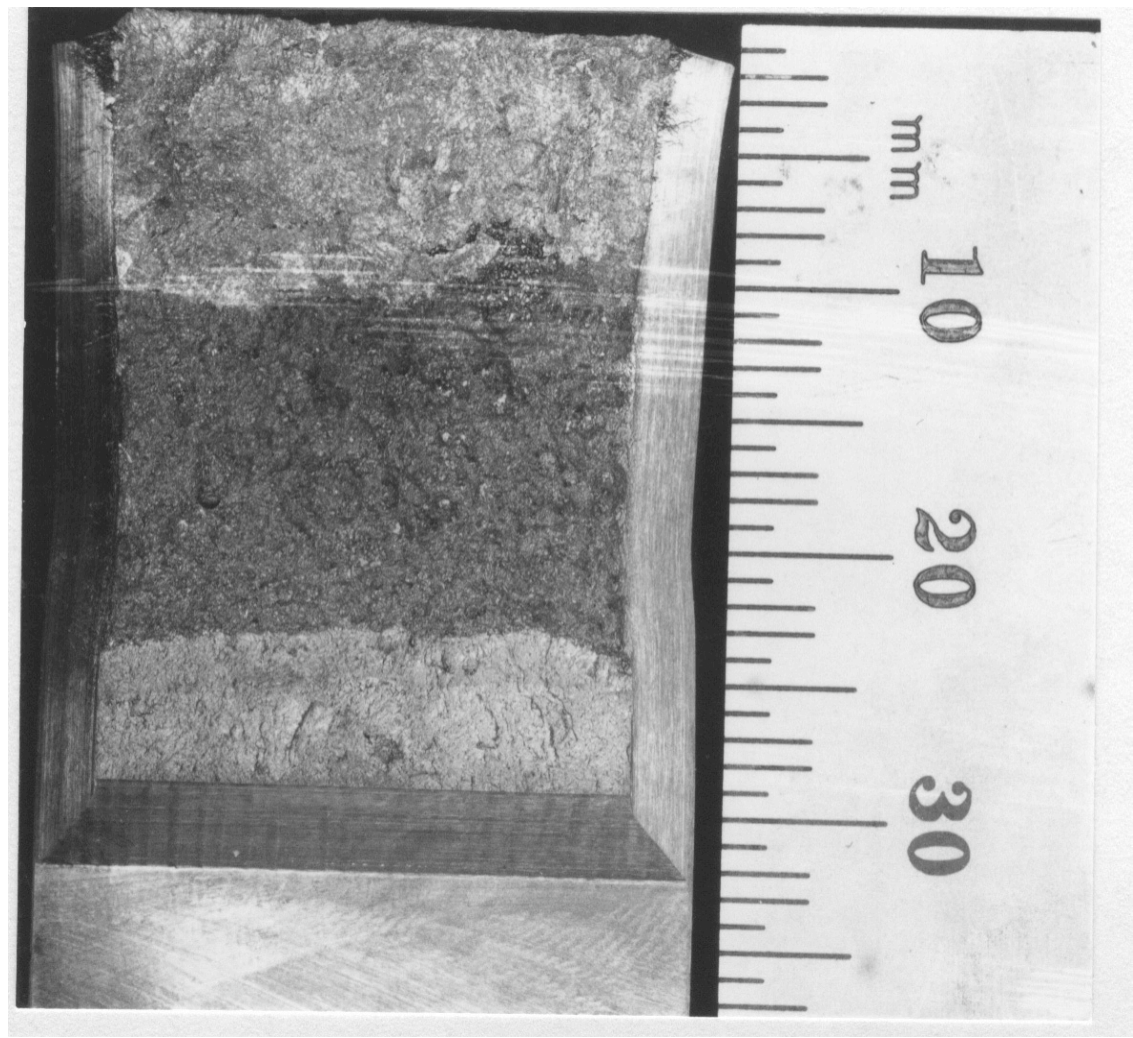

Figure C-59. Fracture surface of the spare pump volute VR aged $10,000 \mathrm{~h}$ at $400^{\circ} \mathrm{C}$ and tested at $290^{\circ} \mathrm{C}$ 


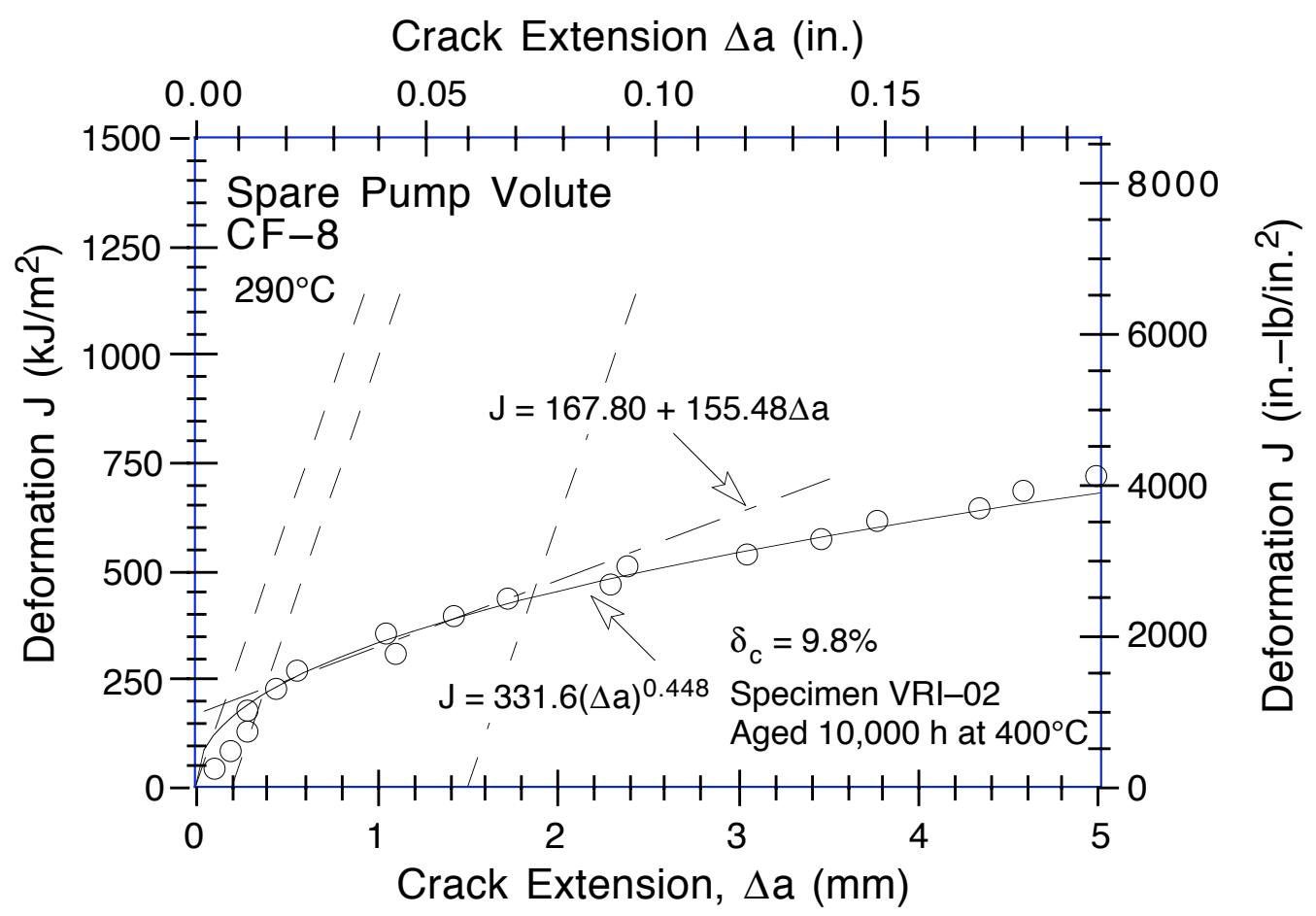

Figure C-60. Deformation $J-R$ Curve at $290^{\circ} \mathrm{C}$ for spare pump volute VR aged $10,000 \mathrm{~h}$ at $400^{\circ} \mathrm{C}$

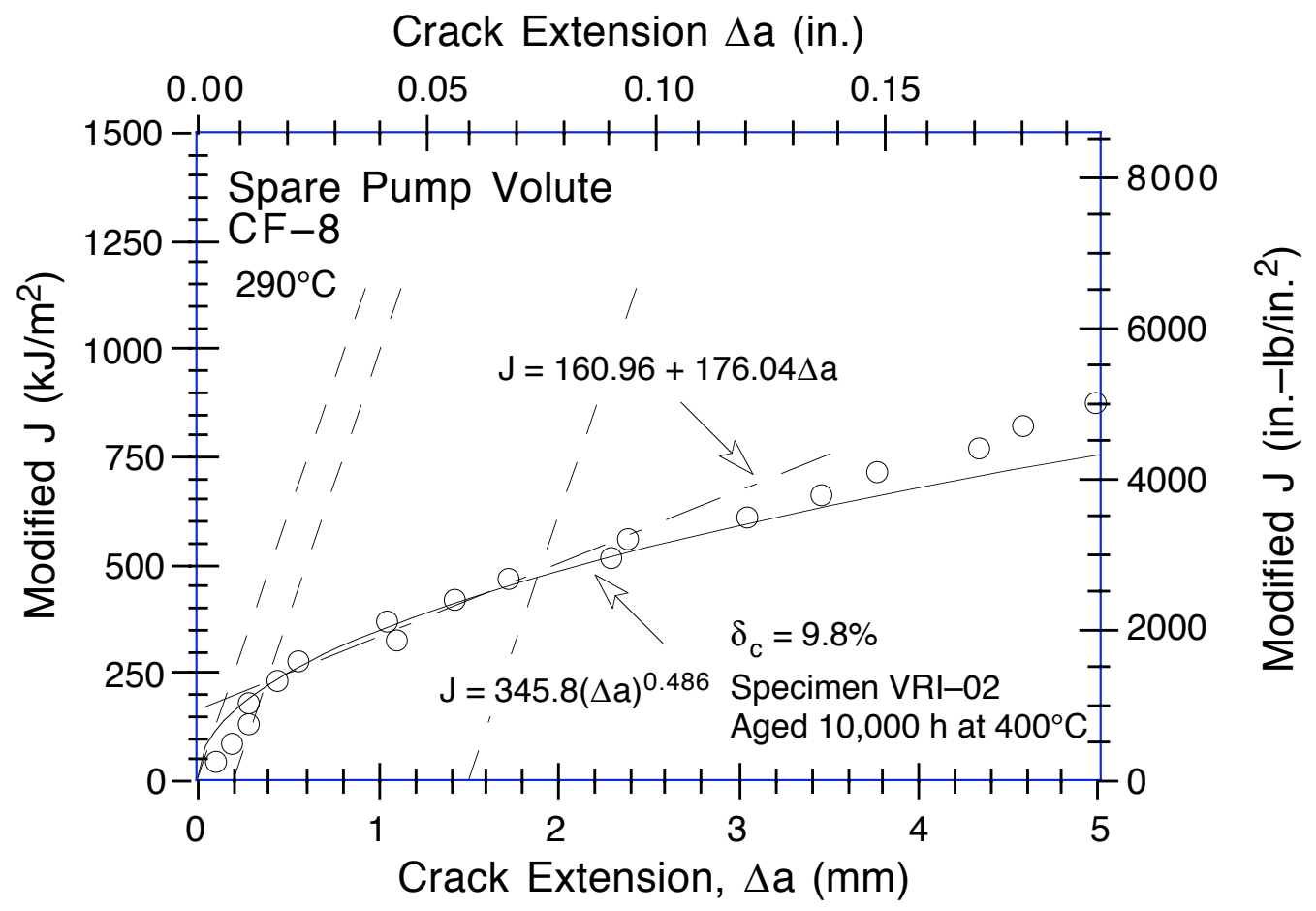

Figure C-61. Modified J-R Curve at $290^{\circ} \mathrm{C}$ for spare pump volute VR aged $10,000 \mathrm{~h}$ at $400^{\circ} \mathrm{C}$ 
Internal:

O. K. Chopra (25)

H. M. Chung

T. F. Kassner

C. Malefyt
R. B. Poeppel

W. J. Shack

C. E. Till

R. W. Weeks

TIS Files

External:

NRC, for distribution per R5

ANL Libraries

ANL-E (2)

ANL-W

Manager, Chicago Field Office, DOE

Energy Technology Division Review Committee

H. K. Birnbaum, University of Illinois, Urbana, IL

R. C. Buchanan, University of Cincinnati, Cincinnati, OH

M. S. Dresselhaus, Massachusetts Institute of Technology, Cambridge, MA

B. G. Jones, University of Illinois, Urbana, IL

C.-Y. Li, Cornell University, Ithaca, NY

S.-N. Liu, Fremont, CA

R. E. Smith, SciTech, Inc., Morrisville, NC

D. Atteridge, Battelle Pacific Northwest Laboratory, Richland

W. H. Bamford, Westinghouse Electric Corp., Pittsburgh, PA

K. K. Bandyopadhyay, Brookhaven National Laboratory, Upton, NY.

J. A. Christensen, Battelle Pacific Northwest Laboratories, Richland

N. G. Cofie, Nutech, San Jose, CA

A. Cowan, Risley Nuclear Power Development Labs., Risley, Warrington, UK

W. H. Cullen, Materials Engineering Associates, Inc., Lanham, MD

B. J. L. Darlaston, Berkeley Nuclear Laboratories, Berkeley, Gloucestershire, UK

G. Gage, AEA Technology, Harwell Laboratory, Oxfordshire, UK

J. Gilman, Electric Power Research Inst., Palo Alto, CA

W. Gysel, Georg Fischer, Ltd., Schaffhausen, Switzerland

G. E. Hale, The Welding Institute, Abington, Cambridge, UK

P. Hedgecock, APTECH Engineering Services, Inc., Palo Alto, CA

B. Hemsworth, HM Nuclear Installations Inspectorate, London

C. Hoffmann, ABB CE Nuclear Power, Windsor, CT

J. Jansky, Buro für Technische Beratung, Leonberg, Germany

C. E. Jaske, CC Technologies, Cortest, Columbus, OH

G. J. Licina, Structural Integrity Associates, San Jose, CA

T. R. Mager, Westinghouse Electric Corp., Pittsburgh, PA

H. Mehta, General Electric Co., San Jose, CA

Y. Meyzaud, Framatome, Paris La Defense, France

M. Prager, Materials Properties Council, Inc., New York, NY

P. H. Pumphrey, National Power, Technology and Environment Center, Leatherhead, Surrey, UK 
D. Quiñones, Robert Cloud \& Associates, Berkeley, CA

C. Y. Rieg, Electricité de France, Villeurbanne Cedex, France

V. N. Shah, EG\&G Idaho, Inc., Idaho Falls, Idaho

G. Slama, Framatome, Paris La Defense, France

G. D. W. Smith, Oxford University, Oxford, UK

H. D. Solomon, General Electric Co., Schenectady, NY

D. M. Stevens, Lynchburg Research Center, Babcock \& Wilcox Co., Lynchburg, VA

L. Taylor, Nuclear Electric plc., Chelsford Rd., Knutsford, Cheshire, UK

J. C. Van Duysen, Electricité de France, Moret-Sur-Loing, France

S. Yukawa, Boulder, CO 
2. TITLE AND SUBTITLE

Mechanical Properties of Thermally Aged Cast Stainless Steels from

Shippingport Reactor Components ANL-94/37

5. AUTHOR(S)

O. K. Chopra and W. J. Shack

3. DATE REPORT PUBLISHED \begin{tabular}{l|l} 
MONTH & YEAR
\end{tabular} April 1995

4. FIN OR GRANT NUMBER

A2256

6. TYPE OF REPORT

Technical

7. PERIOD COVERED (Inc/usive Dates)

8. PERFORMING ORGANIZATION - NAME AND ADDRESS (If NRC, provide Division, Office or Region, U.S. Nuclear Regulatory Commission, and mailing address; if contractor, provide name and mailing address.)

Argonne National Laboratory

9700 South Cass Avenue

Argonne, IL 60439

9. SPONSORING ORGANIZATION - NAME AND ADDRESS (If NRC, type "Same as above": if contractor, provide NRC Division, Office or Region, U.S. Nuclear Regulatory Commission, and mailing address.)

Division of Engineering

Office of Nuclear Regulatory Research

U. S. Nuclear Regulatory Commission

Washington, DC 20555

10. SUPPLEMENTARY NOTES

11. ABSTRACT (200 words or less)

Thermal embrittlement of static-cast CF-8 stainless steel components from the decommissioned Shippingport reactor has been characterized. Cast stainless steel materials were obtained from four cold-leg check valves, three hot-leg main shutoff valves, and two pump volutes. The actual time-at-temperature for the materials was $\approx 13$ y at $\approx 281^{\circ} \mathrm{C}$ for the hot-leg components and $\approx 264^{\circ} \mathrm{C}$ for the cold-leg components. Baseline mechanical properties for as-cast material were determined from tests on either recovery-annealed material or material from the cooler region of the component. The Shippingport materials show modest decreases in fracture toughness and Charpy-impact properties and a small increase in tensile strength because of relatively low service temperatures and ferrite content of the steel. The procedure and correlations developed at Argonne National Laboratory for estimating mechanical properties of cast stainless steels predict accurate or slightly lower values for Charpy-impact energy, tensile flow stress, fracture toughness J-R curve, and $J_{I C}$ of the materials. The kinetics of thermal embrittlement and degree of embrittlement at saturation were established from materials that were aged further in the laboratory. The results were consistent with the estimates. The correlations successfully predicted the mechanical properties of the Ringhals 2 reactor hot- and crossover-leg elbows $(\mathrm{CF}-8 \mathrm{M})$ after service of $\approx 15 \mathrm{y}$ and the KRB reactor pump cover plate (CF-8) after $\approx 8$ y of service.

12. KEY WORDS/DESCRIPTORS (List words or phrases that will assist researchers in locating this report.)

Shippingport reactor

Cast stainless steel

Thermal aging

Embrittlement

Fracture toughness

J-R curve

Impact strength

Tensile strength

Ramberg-Osgood equation

\begin{tabular}{l}
$\begin{array}{l}\text { 13. AVAILABILITY STATEMENT } \\
\text { Unlimited }\end{array}$ \\
\hline $\begin{array}{l}\text { 14. SECURITY CLASSIFICATION } \\
\text { (This Page) } \\
\text { Unclassified }\end{array}$ \\
$\begin{array}{l}\text { (This Report) } \\
\text { Unclas ified }\end{array}$ \\
\hline $\begin{array}{l}\text { 15. NUMBER OF PAGES } \\
\text { 16. PRICE }\end{array}$ \\
\hline
\end{tabular}

